\author{
UNIVERSIDADE DE SÃO PAULO \\ ESCOLA POLITÉCNICA \\ DEPARTAMENTO DE ENGENHARIA METALÚRGICA E DE \\ MATERIAIS
}

VIVIAM SERRA MARQUES PEREIRA

Efeito de características microestruturais na difusividade do hidrogênio em dois aços grau API X65

São Paulo 


\section{Efeito de características microestruturais na difusividade do hidrogênio em dois aços grau API X65}

Dissertação apresentada à Escola Politécnica da Universidade de São Paulo para a obtenção do título de Mestre em Ciências.

Área de Concentração: Engenharia Metalúrgica e de Materiais

Orientador: Prof. Dr. Helio Goldenstein

São Paulo 
Este exemplar foi revisado e corrigido em relação à versão original, sob responsabilidade única do autor e com a anuência de seu orientador.

São Paulo, de de

Assinatura do autor:

Assinatura do orientador:

Catalogação-na-publicação

Serra Marques Pereira, Viviam

Efeito de características microestruturais na difusividade do hidrogênio em dois aços grau API X65 / V. Serra Marques Pereira -- versão corr. -- São Paulo, 2017.

178 p.

Dissertação (Mestrado) - Escola Politécnica da Universidade de São Paulo. Departamento de Engenharia Metalúrgica e de Materiais.

1.Fragilização por hidrogênio 2.Aços microligados 3.Permeabilidade ao hidrogênio I.Universidade de São Paulo. Escola Politécnica. Departamento de Engenharia Metalúrgica e de Materiais II.t. 
Nome: PEREIRA, Viviam Serra Marques

Título: Efeito de características microestruturais na difusividade do hidrogênio em dois aços grau API X65

Dissertação apresentada à Escola Politécnica da Universidade de São Paulo para a obtenção do título de Mestre em Ciências.

Aprovada em:

Banca Examinadora

Prof. Dr.

Instituição:

Julgamento:

Prof. Dr.

Instituição:

Julgamento:

Prof. Dr.

Instituição:

Julgamento: 


\section{DEDICATÓRIA}

Em memória a minha avó, Nadima Raci Marques Pereira e a meu tio avô, Aristides de Sá, que ficariam felizes por mais essa conquista. 


\section{AGRADECIMENTOS}

À minha família, em especial a meus pais Xerxes Raci Marques Pereira e Isabel Cristina Serra Marques Pereira, pelo apoio e carinho durante todos esses anos, aos meus irmãos Alexandre e Leo, que sempre contribuem com risadas. Aos meus avós, vô Nicola e vó Lourdes, por tantos almoços, precoupação, carinho! Aos meus tios, em especial à tia Nádia, por sua amizade e carinho! Obrigada a todos.

Ao meu orientador, prof. Dr. Helio Goldenstein, por toda a sua confiança, compreensão, amizade, empolgação, supervisão, sugestões excelentes e esclarecedoras! Por toda ajuda durante o mestrado e também na busca do doutorado.

À profa. Dra. Neusa Alonso Falleiros, por sempre tirar as minhas dúvidas, por suas sugestões, e pela incansável dedicação que tem a todos os alunos.

Ao Dr. Duberney Hincapie-Ladino pela fundamental ajuda desde os meus primeiros dias de mestrado. Pela paciência infinita ao me ensinar o ensaio de permeabilidade ao hidrogênio, por todas as valiosas discussões e explicações sobre o mundo da fragilização por hidrogênio.

Ao Dr. Isaac Jamil Sayeg, pelos vários anos de grande amizade, conversas, discussões ricas sobre ciência e infinitas risadas. E nunca vou deixar de agradecer por ter me escolhido para ser estagiária em seu projeto de doutorado - foi o acontecimento que decidiu o meu rumo profissional/acadêmico.

Ao prof. Dr. Renato Altobelli Antunes, pela orientação durante toda a graduação e amizade, que continua até os dias de hoje (e espero que continue por muitos anos mais!).

Ao prof. Dr. Mario Fernando Gonzalez Ramirez, por toda ajuda durante boa parte do período de mestrado. Pelas grandes aulas que me dava sobre aços microligados e fragilização por $\mathrm{H} \mathrm{e}$ pela enorme paciência com minhas dúvidas!

Ao prof. Dr. Hercílio Gomes de Melo, pela acolhida junto de seus alunos de corrosão, simpatia, amizade e ótimas aulas sobre corrosão.

Ao meu grande amigo Antônio Livio Nunes da Silva, por todos esses anos me ajudando no PMT, desde antes do mestrado! Pelas risadas, amizade, carinho, por tudo!

Aos colegas e amigos do LTF: Lucas, Ana Paula, Arthur, Jacy, Roberto, Dany, Felipe, Eduardo, Edgar, todos os Andrés, Paula Fernanda (mesmo longe!). Vocês fazem do laboratório um lugar muito mais divertido! 
Aos colegas e amigos do LPE: Marco, Rocio, Wilmar, Sandra, Juan, Janeth, Reginaldo. Marco, obrigada por sempre discutir os resultados e me ajudar com os ensaios de permeabilidade!

E por último, porém nem um pouco menos importante, aos meus queridos amigos: Letícia, Cris, Guilherme, Beatriz, Renata, Ricardo, Marcelli, meninas do Jota, Rafael, Gustavo, Adriano, Jumile, Carol, Karol, Giovanna, Roberto, Nathan. Eu poderia escrever mais um monte de páginas sobre todos os momentos bons e importantes que tive junto de vocês. Obrigada pelo companheirismo e pela torcida, sempre! Obrigada Otilia, Angélica, meninas da dança do ventre e do Espaço Rasa: vocês ajudaram a acrescentar cor e arte à minha vida. 


\section{RESUMO}

Os aços de alta resistência e baixa liga são amplamente utilizados em dutos transportadores de óleo e gás e, atualmente, o desenvolvimento de novos projetos de liga e o uso de técnicas altamente avançadas de fabricação e processamento dos aços se tornaram essenciais para obtenção de estruturas que resistam aos danos provocados por $\mathrm{H}$, principal motivo de falha de oleodutos e gasodutos em meios ricos em $\mathrm{H}_{2} \mathrm{~S}$. No presente trabalho, avaliou-se o efeito de características microestruturais na difusividade do $\mathrm{H}$ em dois aços grau API X65, com diferentes teores de Mn. Uma das chapas ainda está em fase experimental de desenvolvimento, tem baixo teor de Mn e foi produzida para aplicação em ambientes sour. A outra chapa tem alto teor de Mn, já é usada comercialmente há alguns anos e foi desenvolvida para trabalho em ambientes doces. Os dois materiais passaram por caracterização microestrutural nas três seções da chapa: longitudinal e transversal à direção de laminação e do topo da chapa (paralela à direção de laminação). Após a caracterização, amostras de cada seção dos aços foram submetidas a ensaios de permeabilidade ao $\mathrm{H}$; o aço baixo $\mathrm{Mn}$ passou por análises de EBSD (Difração de Elétrons Retroespalhados), para determinação de textura. $\mathrm{O}$ aço baixo $\mathrm{Mn}$ tem microestrutura homogênea ao longo da espessura da chapa, composta por ferrita refinada e pequenas ilhas de perlita. $\mathrm{O}$ aço alto $\mathrm{Mn}$, por sua vez, apresenta microestrutura heterogênea ao longo da espessura, formada por bandas de ferrita e perlita, com marcada presença de segregação central de elementos de liga. Os ensaios de permeabilidade ao $\mathrm{H}$ mostraram que os coeficientes de difusão efetiva do $\mathrm{H}, \mathrm{D}_{\text {eff }}$, do aço baixo Mn são ligeiramente superiores aos do aço alto Mn. Outros dois importantes parâmetros que foram calculados para os dois aços são a concentração de H na sub-superfície do material, $\mathrm{C}_{0}$, e o número de traps por unidade de volume, $\mathrm{N}_{\mathrm{t}}$. Contrariando expectativas, o aço baixo Mn apresentou maiores valores de $\mathrm{C}_{0}$ e $\mathrm{N}_{\mathrm{t}}$ do que o aço alto Mn. Ensaios preliminares de dessorção térmica realizados nos dois aços mostraram os mesmos resultados: o aço baixo Mn aprisiona mais $\mathrm{H}$ do que o aço alto $\mathrm{Mn}$. Estes resultados contraditórios de $\mathrm{C}_{0}$ e $\mathrm{N}_{\mathrm{t}}$ foram atribuídos à presença de nanoprecipitados de microadições de liga no aço baixo Mn, não detectáveis por microscopia óptica e eletrônica de varredura. Ainda, para os dois aços, os valores de $\mathrm{D}_{\text {eff }}$ variaram em função da seção analisada da seguinte maneira: $\mathrm{D}_{\text {eff }}$ longitudinal $\cong \mathrm{D}_{\text {eff }}$ transversal $>\mathrm{D}_{\text {eff }}$ topo. Para entender melhor o comportamento anisotrópico da difusão do $\mathrm{H}$ nos dois aços calculou-se um novo coeficiente de difusão, que foi chamado de coeficiente de difusão no estado estacionário, $\mathrm{D}_{\mathrm{ss}}$. $\mathrm{O}_{\mathrm{ss}}$ considera que todos os traps do aço estão saturados, permitindo, assim que se avalie somente o efeito de obstáculos físicos à 
difusão do $\mathrm{H}$. No aço alto $\mathrm{Mn}$, o $\mathrm{D}_{\mathrm{ss}}$ variou da mesma maneira que o $\mathrm{D}_{\text {eff: }}$ : $\mathrm{D}_{\mathrm{ss}}$ longitudinal $\cong$ $\mathrm{D}_{\mathrm{ss}}$ transversal $>\mathrm{D}_{\mathrm{ss}}$ topo; este comportamento foi atribuído ao bandeamento presente no material. No aço baixo $M n$, o $D_{s s}$ variou de forma diferente do $D_{\text {eff: }} D_{s s}$ transversal $>D_{s s}$ longitudinal $\geq \mathrm{D}_{\mathrm{ss}}$ topo, indicando que a difusão do $\mathrm{H}$ pode ser auxiliada por contornos de grão enquanto os traps estão sendo saturados, e que a textura cristalográfica pode influenciar a difusão após o estado estacionário ser atingido.

Palavras-chave: Aço microligado. Alto Nb. Comprimento de contornos de grão. Estado estacionário. Microtextura. 


\begin{abstract}
High strength low alloy steels are widely applied as pipelines for crude oil and natural gas transportation and, currently, new approaches to alloy design, in addition to the use of advanced steelmaking and processing techniques, have become essential for obtaining structures that resist to hydrogen damage, which is the main cause of pipelines failure in $\mathrm{H}_{2} \mathrm{~S}$ rich environments. The main objective of the present work is to evaluate the influence of microstructural features on hydrogen diffusivity in two API X65 steels, with different Mn contents. One of the steel plates has been recently developed for usage in sour environments, is on its experimental stage and has a low Mn content. The other one is a commercial plate steel, with high Mn content, developed for sweet applications. Both steel plates were characterized in its three sections, in relation to the rolling direction: longitudinal, transverse and top surface of the plate (parallell to the rolling direction). After that, samples obtained from each section of the plates were submitted to hydrogen permeation tests; the low Mn steel was also analysed with EBSD, for texture determination. The low Mn steel presents a homogeneous microstructure through plate thickness, composed of refined ferrite and small pearlite islands. The high $\mathrm{Mn}$ steel has a heterogeneous microstructure through the plate thickness, composed of ferrite and pearlite bands, and presents centerline segregation. Hydrogen permeation tests showed that the $\mathrm{D}_{\text {eff }}$ obtained for the low $\mathrm{Mn}$ steel sections are slightly higher than for the high Mn steel. Another two important parameters that were calculated for both steels are the subsurface hydrogen concentration, $\mathrm{C}_{0}$, and the number of traps per unit volume, $\mathrm{N}_{\mathrm{t}}$. Contrary to what was expected, the low Mn steel presented the higher $\mathrm{C}_{0}$ and $\mathrm{N}_{\mathrm{t}}$ values. Thermal dessorption spectroscopy analysis confirmed that the low Mn steel traps more $\mathrm{H}$ atoms than the high $\mathrm{Mn}$ one. These results, along with the similar $\mathrm{D}_{\text {eff }}$ values, were related to the presence of nanoprecipitates of microalloying elements, that cannot be detected via optical and scanning electron microscopy. Additionally, also for both steels, the $D_{\text {eff }}$ values varied in function of the analyzed section as it follows: $D_{\text {eff }}$ longitudinal $\cong D_{\text {eff }}$ transverse $>D_{\text {eff }}$ top. In order to better understand this anisotropic behavior, a new diffusion coefficient, which was called diffusion coefficient at the steady state, $D_{s s}$, was determined. $D_{s s}$ considers that all the trapping sites are saturated, enabling, thus, the evaluation of physical obstacles to $\mathrm{H}$ diffusion. For the high $\mathrm{Mn}$ steel, the $\mathrm{D}_{\mathrm{ss}}$ varied in the same matter as the $\mathrm{D}_{\text {eff: }}$ : $D_{\mathrm{ss}}$ longitudinal $\cong D_{\mathrm{ss}}$ transverse $>D_{\mathrm{ss}}$ top; this behavior was associated with the microstructural banding present in the material. For the low Mn steel, the $\mathrm{D}_{\mathrm{ss}}$ exhibited a different behavior: $\mathrm{D}_{\mathrm{ss}}$ transverse $>\mathrm{D}_{\mathrm{ss}}$ longitudinal $\geq \mathrm{D}_{\mathrm{ss}}$ top, suggesting that $\mathrm{H}$ diffusion can
\end{abstract}


be aided by grain boundaries while the trapping sites are being filled and that crystallographic texture may play its role after the steady state is reached.

Keywords: Microalloyed steel. High Nb. Grain boundary lenght. Steady state. Microtexture. 


\section{SUMÁRIO}





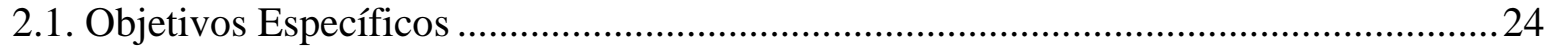



3.1. Generalidades dos Aços de Alta Resistência e Baixa Liga, (High Strength Low Alloy,

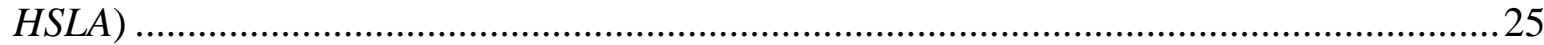

3.2. Método termomecânico de laminação controlada, (TMCR) ......................................... 30

3.3. HSLA na indústria de transporte de óleo e gás ............................................................ 30

3.4. Ambientes sour e a fragilização por hidrogênio........................................................... 39





3.7. Difusão do hidrogênio pela rede cristalina da ferrita e a influência da textura

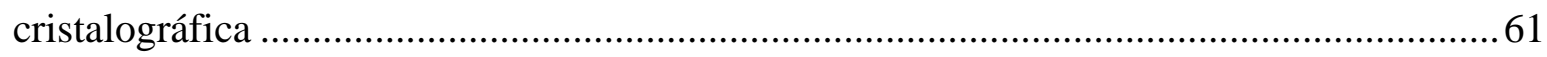

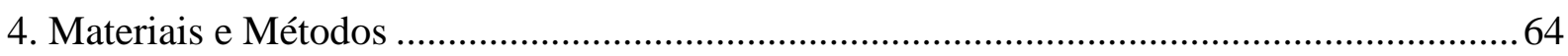

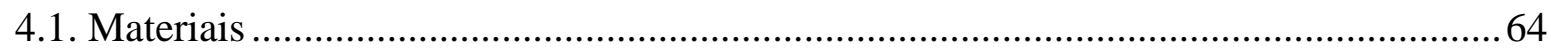

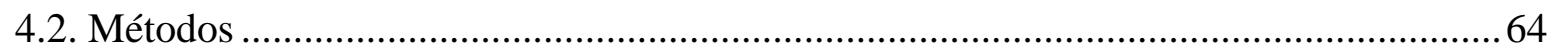

4.2.1. Caracterização Microestrutural por Microscopia Óptica e Eletrônica de Varredura .64

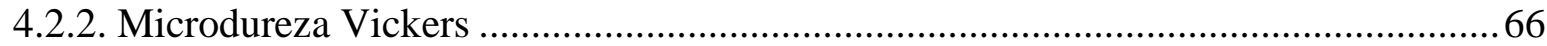

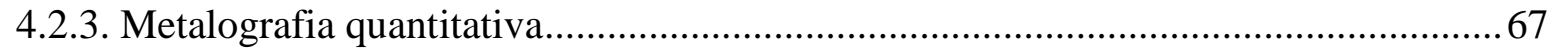

4.2.4. Difração de Elétrons Retroespalhados (EBSD) ........................................................ 72

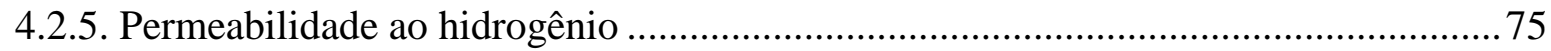

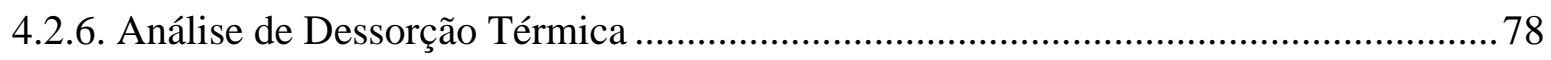

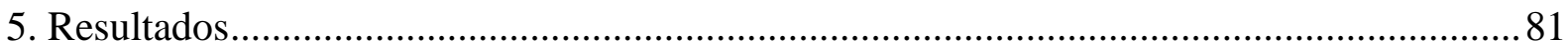

5.1. Caracterização Microestrutural por Microscopia Óptica e Eletrônica de Varredura ....81

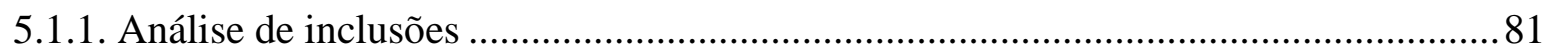

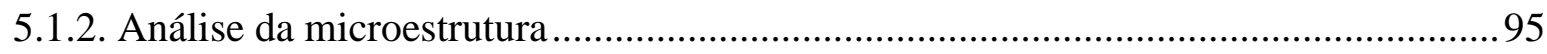

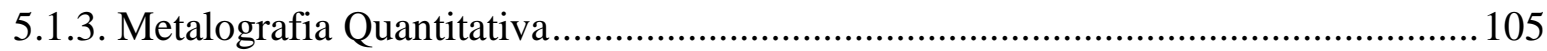




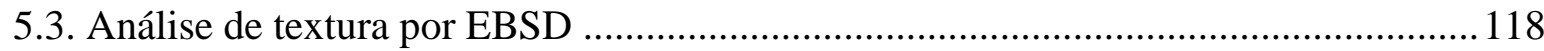

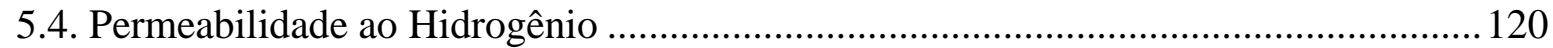

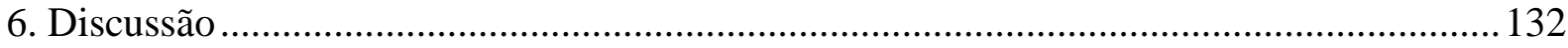

6.1. Comparação entre os dois aços: características microestruturais e resultados do ensaio

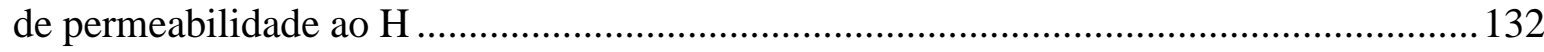

6.2. Análise do aço alto Mn: efeito do bandeamento .................................................... 142

6.3. Análise do aço baixo Mn: efeito da quantidade de contornos de grão de ferrita e da

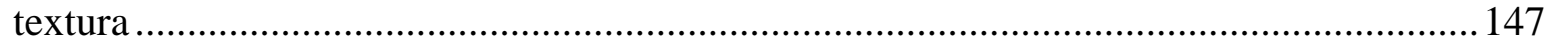

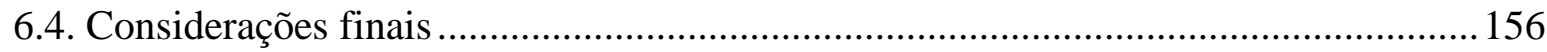



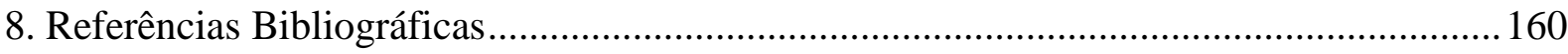

APÊNDICE A: Método termomecânico de laminação controlada, (TMCR) ......................... 168 


\section{LISTA DE FIGURAS}

Figura 1. Solubilidade estimada do hidrogênio no ferro, em função da temperatura e das transformações alotrópicas do ferro puro, para pressão parcial de $\mathrm{H}_{2}$ de 1 atm e temperaturas superiores a $400{ }^{\circ} \mathrm{C}$. Modificado de [27].

Figura 2. Micrografias ópticas de dois tubos X52, fornecidos por diferentes empresas. (A) Microestrutura de tubo usado comercialmente em ambientes sour, composta por ferrita (claro) e perlita (escuro). (B) Microestrutura de tubo em estágio experimental, composta por ferrita acicular refinada. Aumento não informado pelo autor. Retirado de [29]

Figura 3. Micrografias ópticas de dois aços para tubos X60, do mesmo fabricante e com composições químicas diferentes. (A) Microestrutura composta por $79 \%$ de ferrita e $21 \%$ de perlita, (B) Microestrutura composta por $95 \%$ de ferrita e 3\% de perlita. Aumento de $500 \mathrm{x}$. Retirado de [5].

Figura 4. Microestrutura de amostra de um tubo API X65 sour, composta por ferrita equiaxial e ferrita acicular. Aumento não informado pelo autor. Retirado de [30].

Figura 5. Micrografia de elétrons secundários do aço X65 após revenimento, mostrando carbonetos (brancos) precipitados preferencialmente nos contornos de grão. Aumento de 10000 x. Retirada de [31].

Figura 6. Microestruturas de dois aços HSLA grau X70, com diferentes teores de Mn. (a) $1,14 \%$ em massa de Mn e (b) 0,5\% em massa de Mn. Aumento não informado pelo autor.Imagens retiradas de [32].

Figura 7. Microestrutura de aço HSLA grau X80; setas vermelhas indicam o microconstituinte MA e as regiões identificadas por GB correspondem à bainita granular. Aumento não informado pelo autor. Imagem retirada de [33].

Figura 8. Microestrutura de tubo API X100. Aumento não informado pelo autor. Imagem retirada de [34]

Figura 9. Esquematização que mostra o processo de entrada de $\mathrm{H}$ atômico na estrutura do aço, em meio sour.

Figura 10. Níveis de energia adquiridos pelo hidrogênio em torno de um trap. Na figura, $\mathrm{E}_{\mathrm{S}}=$ energia de ativação necessária para migração de um átomo de $\mathrm{H}$ a partir de um sítio da rede cristalina para um trap; $\mathrm{E}_{\mathrm{B}}=$ energia de ligação do átomo de $\mathrm{H}$ com o trap; $\mathrm{S}_{\mathrm{T}}=$ energia do átomo de $\mathrm{H}$ no trap; $\mathrm{E}_{\mathrm{aT}}=$ energia de ativação para que o átomo de $\mathrm{H}$ escape do trap; $\mathrm{E}_{\mathrm{aD}}=$ 
energia de ativação para que o átomo de $\mathrm{H}$ se difunda pela rede cristalina e $\mathrm{S}_{\mathrm{N}}=$ energia do átomo de $\mathrm{H}$ em um sítio intersticial da rede. Modificado de [44].

Figura 11. Resultados de análise de dessorção térmica para aços com diferentes teores de Ti e de $\mathrm{C}$, mostrando os picos referentes à interface TiC-Fe. Modificado de [44].

Figura 12. (a) Micrografia de elétrons retroespalhados que mostra trinca iniciada em inclusão. (b) Análise química composicional, obtida por EDS, da inclusão destacada em (a). Aumento usado não indicado pelos autores [37]....

Figura 13. Micrografia que mostra o trincamento induzido por hidrogênio na linha central de uma chapa de aço X70. Aumento: 1000 x. Modificado de [27].

Figura 14. Níveis de energia apresentados pelo átomo de $\mathrm{H}$ em torno de uma interface ferrita/cementita; valores de energia em kJ.mol ${ }^{-1}$. Modificado de [52].

Figura 15. À esquerda: micrografias óticas de amostras de ferrita pura com diferentes tamanhos de grão ASTM (a) ASTM n² 2, (b) ASTM n ${ }^{\circ}$ 4, (c) ASTM n 7 e (d) ASTM n 9. Aumento usado para todas as micrografias: 65 x. À direita: resultados de dessorção térmica para as mesmas amostras. O pico associado aos contornos de ferrita é indicado pela seta vermelha. Modificado de [50].

Figura 16. Esquematização do sistema básico de células eletroquímicas usado no ensaio de permeabilidade ao H. Modificado de [68].

Figura 17. Ilustração do volume de amostra que é saturado e percorrido por $\mathrm{H}$ durante o ensaio de permeabilidade, com aplicação de potencial anódico. 56

Figura 18. Desenho de uma curva ideal resultante de um ensaio de permeabilidade ao hidrogênio. Em (i) região do transiente, na qual a densidade de corrente $\left(i_{A}\right)$ aumenta com o tempo, em (ii) a região do estado estacionário, onde $\mathrm{i}_{\mathrm{A}}$ é constante ao longo do tempo e (iii) região de decaimento, em que $i_{\mathrm{A}}$ diminui com o tempo. Retirada de [68] ...............................57

Figura 19. Faces da chapa analisadas com relação à direção de laminação (DL)....................65

Figura 20. Representação das regiões das amostras analisadas por microscopia...... 65

Figura 21. Esquematização da varredura superficial, para cada seção, feita com o microscópio óptico para análise das inclusões.

Figura 22. Célula eletroquímica usada para niquelação; $\mathrm{CE}=$ contra-eletrodo de níquel, $\mathrm{ER}=$ eletrodo de referência de calomelano saturado e ET = eletrodo de trabalho (amostra a ser niquelada).

Figura 23. Células eletroquímicas montadas para ensaio de permeabilidade. Em (A) tem-se a célula de geração de hidrogênio, em (B), a célula de oxidação e em (C) a amostra. 76 
Figura 24. Exemplo de amostra após o ensaio de permeabilidade ao hidrogênio. (a) Face de saída dos átomos de $\mathrm{H}$, niquelada, exposta à célula de oxidação e (b) face de entrada dos átomos de $\mathrm{H}$, exposta à célula de geração de $\mathrm{H}$

Figura 25. Arranjo experimental usado para fazer o carregamento com H no LNNano. Em A, conexão das amostras (indicadas pelas setas vermelhas) com a fonte de tensão; em B, conexão do contra-eletrodo de platina (indicado pela seta amarela) com a fonte de tensão.

Figura 26. Inclusões presentes no aço baixo Mn. (a) Seção longitudinal da chapa e (b) seção transversal. Aumento: $100 \mathrm{x}$, sem ataque.

Figura 27. Inclusões presentes no aço alto Mn, na seção longitudinal. (a) Região superior direita da amostra, (b) centro da amostra e (c) região inferior direita. Aumento: 100 x, sem ataque.

Figura 28. Micrografia de elétrons retroespalhados da superfície longitudinal ao sentido de laminação da chapa de aço baixo Mn; aumento de 1000 x. Destaque: inclusão com aumento de 5000 x. Abaixo, composição química da inclusão mostrada em destaque.Ataque: Nital 2\%.

Figura 29. Micrografia de elétrons retroespalhados da superfície transversal ao sentido de laminação da chapa de aço baixo Mn; aumento de 5000 x. Abaixo, composição química da inclusão no centro da imagem. Ataque: Nital 2\%. 86

Figura 30. Micrografia de elétrons retroespalhados da superfície longitudinal ao sentido de laminação da chapa de aço baixo Mn; aumento de 5000 x. Ataque: Nital 2\%. Abaixo, composição química da inclusão no centro da imagem.

Figura 31(a). Micrografia de elétrons retroespalhados da superfície longitudinal ao sentido de laminação da chapa de aço alto Mn; aumento de 5000 x. Ataque: Nital 2\%. Abaixo, composição química da inclusão no centro da imagem.

Figura 32(a). Micrografia de elétrons retroespalhados da superfície transversal ao sentido de laminação da chapa do aço alto Mn; aumento de 5000 x. Ataque: Nital 2\%. Abaixo, composição química da inclusão no centro da imagem. 92

Figura 33. Microestruturas das seções (a) longitudinal, (b) transversal e (c) topo do aço baixo Mn. Ataque: Nital 2\%. Aumento de 500 x.

Figura 34. Micrografias ópticas das diferentes seções do aço alto Mn. (a) região periférica e (b) região central da superfície longitudinal; (c) região periférica e (d) região central da superfície transversal; (e) região periférica e (f) região central do topo da chapa. Ataque: Nital 2\%. Aumento: $200 \mathrm{x}$ 
Figura 35. Micrografias ópticas das diferentes seções do aço alto $\mathrm{Mn}$, em suas regiões centrais. (a) Longitudinal, (b) transversal, (c) e (d) topo. Ataque: Nital 2\%. Aumento: 500 x.

Figura 36. Micrografias de elétrons secundários dos dois aços estudados. (a) Seção longitudinal do aço baixo Mn, (b) seção longitudinal do aço alto Mn, (c) seção transversal do aço baixo Mn e (d) seção transversal do aço alto Mn. Aumentos de 150 x (a e c) e de 135 x (b e d). Ataque: Nital 2\%.

Figura 37. Micrografias de elétrons secundários do aço baixo Mn. (a) Seção longitudinal, (b) transversal e (c) topo. Aumento: 2500 x. Ataque: Nital 2\%.

Figura 38. Micrografia de elétrons secundários da amostra longitudinal do aço baixo Mn. As setas em vermelho destacam algumas das perlitas presentes na microestrutura. Aumento: 5000 x. Ataque: Nital $2 \%$. 102

Figura 39. Micrografias de elétrons secundários do aço alto Mn. (a) região periférica da seção longitudinal, (b) região de banda central da seção longitudinal, (c) região periférica da seção transversal e (d) região de banda central da seção transversal.

Figura 40. Micrografia de elétrons secundários de amostra retirada do topo da chapa do aço alto Mn. Aumento: 2500 x. Ataque: Nital 2\%.

Figura 41. Micrografia de elétrons retroespalhados de amostra longitudinal do aço alto Mn, junto de espectros de EDS (detalhes na imagem) e tabela com os principais elementos encontrados na análise química. Aumento: 5000 x. Ataque: Nital 2\%. 104 Figura 42. Micrografia de elétrons retroespalhados de amostra transversal do aço alto Mn, junto de espectros de EDS (detalhes na imagem) e tabela com os principais elementos encontrados na análise química. Aumento: 5000 x. Ataque: Nital 2\%.

Figura 43. Exemplos de micrografias usadas para medição de fração volumétrica de perlita com o analisador de imagens. Aço baixo Mn: (a) seção longitudinal, (b) seção transversal e (c) topo da chapa. Aço alto Mn: (d) seção longitudinal, (e) seção transversal e (f) topo da chapa

Figura 44. (a) Exemplo de área análisada (frame) por EBSD, (b) tabela com valores de diâmetros de grãos e suas frações de área e (c) curva de distribuição.

Figura 45. Distribuição de diâmetro de grão para amostra longitudinal do aço baixo Mn. ... 111 Figura 46. Distribuição de diâmetro de grão para amostra transversal do aço baixo Mn......111

Figura 47. Distribuição de diâmetro de grão para amostra topo do aço baixo Mn. 112 
Figura 48. Comparação das curvas de distribuição de diâmetro de grão para todas as amostras do aço baixo $\mathrm{Mn}$.

Figura 49. Mapas de índice de qualidade (QI) e de contornos de grão. Contornos em azul: alto ângulo (entre $15^{\circ}$ e $180^{\circ}$ ); em verde: médio ângulo (entre $5^{\circ}$ e $15^{\circ}$ ) e em vermelho: baixo ângulo (entre $2^{\circ}$ e $5^{\circ}$ ). Em (a) amostra longitudinal, (b) topo e (c) transversal do aço baixo $\mathrm{Mn}$. 115

Figura 50. Mapas de orientação de figura de pólo inverso (IPF) combinados com os índices de qualidade (QI) para as amostras do aço baixo Mn. (a) Longitudinal, (b) transversal, (c) topo e (d) triângulo IPF

Figura 51. Curvas de permeabilidade ao $\mathrm{H}$ para amostras dos aços baixo e alto Mn. (a) curvas normalizadas das amostras longitudinais e transversais, (b) curvas normalizadas das amostras topo, (c) curvas não normalizadas amostras longitudinais e transversais e (d) curvas não normalizadas amostras topo

Figura 52. Comparação entre os valores de coeficiente de difusão efetiva calculados pelo método do $t_{\text {lag }}\left(D_{\text {eff }} t_{\text {lag }}\right)$ para os dois aços

Figura 53. Comparação entre os valores de concentração de $\mathrm{H}$ na subsuperfície do aço $\left(\mathrm{C}_{0}\right)$ calculados para os dois aços.

Figura 54. Comparação entre os números de sítios de aprisionamento de hidrogênio por unidade de volume $\left(\mathrm{N}_{\mathrm{t}}\right)$ calculados para os dois aços.

Figura 55. Valores de fluxo de $\mathrm{H}$ desprendidos pelos aços baixo Mn (vermelho) e alto Mn (hachurado) durante ensaio de dessorção térmica.

Figura 56. Micrografia de elétrons secundários mostrando colônia de perlita fina presente em amostra longitudinal do aço alto Mn. Ataque: Nital 2\%; Aumento: 10000x

Figura 57. Frações molares de NbC em função da temperatura, obtidas por Thermo-Calc. (a) Aço baixo Mn, (b) aço alto Mn.

Figura 58. Esquematização para mostrar átomos de $\mathrm{H}$ frente às placas de perlita, para cada seção de um aço bandeado. Modificado de [64].

Figura 59. Micrografias ópticas das diferentes seções do aço alto Mn. (a) região periférica e (b) região central da superfície longitudinal; (c) região periférica e (d) região central da superfície transversal. Ataque: Nital 2\%. Aumento: 200 x.

Figura 60. Micrografias ópticas das diferentes seções do aço alto $\mathrm{Mn}$, em suas regiões centrais. (a) Longitudinal e (b) transversal. Ataque: Nital 2\%. Aumento: 500 x 
Figura 61. Valores do novo coeficiente de difusão no estado estacionário, $\mathrm{D}_{\mathrm{ss}}$, calculados para as seções longitudinal, transversal e topo do aço alto Mn.................................................... 147 Figura 62. Esquematização mostrando os átomos de $\mathrm{H}$ frente à microestrutura aleatória.

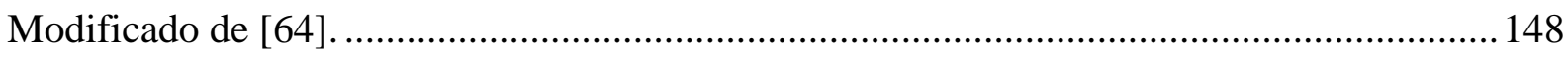

Figura 63. Valores do coeficiente de difusão do $\mathrm{H}$ no estado estacioonário, $\mathrm{D}_{\mathrm{ss}}$, calculados para as três seções do aço baixo Mn. 153

Figura 64. (Reapresentação) Mapas de orientação de IPF combinados com IQ para as amostras do aço baixo Mn. (a) Longitudinal, (b) transversal, (c) topo e (d) triângulo IPF.... 154 


\section{LISTA DE TABELAS}

Tabela 1. Grau API de aços, microestrutura correspondente e composição química convencional. Traduzido e modificado de [19-21]. 28

Tabela 2. Requisitos especiais que os aços para oleodutos devem possuir, para conseguirem suportar as condições mais agressivas e extremas de serviço, e a implicação destas necessidades na produção dos aços. Traduzido de [19]. 31

Tabela 3. Métodos especiais usados para fabricação de aços grau X52 e X65 sour [7,27]..... 34

Tabela 4. Valores de $\mathrm{E}_{\mathrm{aT}}$ e $\mathrm{E}_{\mathrm{B}}$ para diferentes tipos de traps de hidrogênio em aços. As referências de cada valor são indicadas entre colchetes [].

Tabela 5. Condições de ensaio de permeabilidade ao $\mathrm{H}$ e os valores do coeficiente de difusão efetiva do $\mathrm{H}\left(\mathrm{D}_{\text {eff }}\right)$ para diferentes aços e microestruturas.

Tabela 6. Coeficientes de difusão efetiva do $\mathrm{H}$ em membranas de níquel policristalino com diferentes texturas, obtidos por Cao et. al. [78].

Tabela 7. Composições químicas dos aços HSLA API grau X65 estudados. 64

Tabela 8. Parâmetros usados para as medidas de microdureza Vickers.

Tabela 9. Valores e etapas para cálculo de $\mathrm{A}_{\text {corrigida. }}$

Tabela 10. Parâmetros e equações usados alterados para determinação do tamanho de grão com base no método de Jeffries.

Tabela 11. Parâmetros e equações para determinação do tamanho de grão pelo método do intercepto linear de Heyn. .71

Tabela 12. Dados usados para o cálculo de $\mathrm{S}_{\mathrm{v}}$ 72

Tabela 13. Etapas para preparo de amostras para EBSD e os parâmetros adotados. 74

Tabela 14. Composição química do eletrólito para niquelação. Valores de \% em massa para o preparo de $1 \mathrm{~L}$ de solução. 76

Tabela 15. Eletrólitos usados nas etapas de decaimento e de permeabilidade ao hidrogênio.. 77 Tabela 16. Frações volumétricas médias de perlita ( $\mathrm{V}_{\mathrm{v}}$ perlita média), seus respectivos desvios padrão e o total de perlitas contadas para as seções longitudinal, transversal e topo dos dois aços.

Tabela 17. Valores médios de tamanho de grão, calculados pelos métodos Planimétrico e do Intercepto Linear. Número de grãos de ferrita contados, número de grãos por unidade de área $\left(\mathrm{N}_{\mathrm{A}}\right)$, área média dos grãos $\left(\mathrm{A}_{\text {Media }}\right)$, diâmetro médio dos grãos $\left(\mathrm{d}_{\mathrm{Médio}}\right)$, número de grãos por 
unidade de comprimento $\left(\mathrm{N}_{\mathrm{L}}\right)$, intercepto médio $(\boldsymbol{l})$ e seus respectivos desvios padrão, para cada seção dos aços baixo e alto Mn.

Tabela 18. Valores médios ponderados dos diâmetros dos grãos, determinados por EBSD, e seus respectivos desvios padrão ponderados, para cada amostra do aço baixo Mn. Lembrando que os desvios padrão ponderados correspondem a uma medida da dispersão dos valores de diâmetros na distribuição.

Tabela 19. Total de grãos de ferrita contados, número de grãos por unidade de comprimento (NL), área superficial de contornos de grão por unidade de volume (Sv) e seus respectivos desvios padrão, obtidos pelo método do Intercepto Circular de Hilliard (aço baixo Mn) e pelo método do Intercepto Linear (dois aços).

Tabela 20. Comprimentos de contornos de grãos em cada amostra analisada por EBSD do aço baixo Mn. As áreas correspondem aos campos analisados para cada amostra. 116

Tabela 21. Valores médios de microdureza e seus respectivos desvios padrão (DV) para as seções longitudinal, transversal e topo dos dois aços.

Tabela 22. Valores de coeficiente de difusão efetiva, $\mathrm{D}_{\text {eff, }}$ calculados pelos métodos do timelag $\left(\mathrm{t}_{\text {lag }}\right)$ e do time-breakthrough $\left(\mathrm{t}_{\mathrm{b}}\right)$, espessuras das amostras (e) e valores de corrente no estado estacionário $\left(\mathrm{I}_{\infty}\right)$, para o aço baixo $\mathrm{Mn}$.

Tabela 23. Valores de coeficiente de difusão efetiva, $\mathrm{D}_{\text {eff, }}$ calculados pelos métodos do timelag $\left(\mathrm{t}_{\mathrm{lag}}\right)$ e do time-breakthrough $\left(\mathrm{t}_{\mathrm{b}}\right)$, espessuras das amostras (e) e valores de corrente no estado estacionário $\left(\mathrm{I}_{\infty}\right)$, para o aço alto $\mathrm{Mn}$.

Tabela 24. Valores de concentração de $\mathrm{H}$ na subsuperfície do aço $\left(\mathrm{C}_{0}\right)$ e de número de sítios de aprisionamento $\left(\mathrm{N}_{\mathrm{T}}\right)$ calculados para o aço baixo Mn. Também são apresentados os valores de coeficiente de difusão efetiva do hidrogênio, obtidos pelo método do time-lag e de fluxo de $\mathrm{H}$ no estado estacionário, utilizados para os cálculos

Tabela 25. Valores de concentração de $\mathrm{H}$ na subsuperfície do aço $\left(\mathrm{C}_{0}\right)$ e de número de sítios de aprisionamento $\left(\mathrm{N}_{\mathrm{T}}\right)$ calculados para o aço alto $\mathrm{Mn}$. Também são apresentados os valores de coeficiente de difusão efetiva do hidrogênio, obtidos pelo método do time-lag e de fluxo de $\mathrm{H}$ no estado estacionário, utilizados para os cálculos

Tabela 26. Principais características microestruturais dos aços baixo e alto Mn, já apresentadas na seção 5.1. do presente trabalho.

Tabela 27. Tipos de traps identificados nos dois aços através de microscopia óptica e

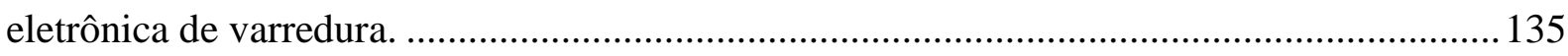

Tabela 28. Composições químicas dos aços HSLA API grau X65 estudados. 138 
Tabela 29. Valores médios de coeficiente de difusão efetiva, calculados pelo método do timelag, ( $\mathrm{D}_{\text {eff }} \mathrm{t}_{\text {lag }}$ ), para as seções longitudinal, transversal e topo do aço alto Mn, junto de seus respectivos desvios padrão, e valores de $\mathrm{D}_{\text {eff }}$ do aço bandeado de Tau e Chan [64].............. 143 Tabela 30. Valores médios de coeficiente de difusão efetiva, calculados pelo método do timelag, ( $\mathrm{D}_{\text {eff }} \mathrm{t}_{\text {lag }}$ ), para as seções longitudinal, transversal e topo do aço baixo $\mathrm{Mn}$, junto de seus respectivos desvios padrão, e valores de $\mathrm{D}_{\text {eff }}$ do aço de microestrutura aleatória de Tau e Chan [64]. 


\section{Introdução e Justificativa}

Atualmente, mesmo com a busca por fontes de energia limpas e renováveis, o petróleo e o gás natural continuam liderando o ranking de combustíveis mais usados no mundo, junto do carvão. De acordo com o estudo temático "Tendências de longo prazo no cenário energético mundial: Agência Nacional de Energia - WEO 2013", publicado pela Superintendência de Pesquisa e Desenvolvimento Tecnológico da ANP em julho de 2014 [1], a demanda mundial de petróleo irá crescer em $13 \%$ até 2035 , em relação ao ano de 2011 , e a de gás natural terá um aumento de 48\%.Ainda, de acordo com esse estudo, o Brasil poderá ser um importante exportador de petróleo, responsável por $1 / 3$ do crescimento da oferta global em 2035.

O cenário atual do petróleo e do gás natural sofrerá mudanças significativas: (i) estes combustíveis serão cada vez mais explorados em reservas não convencionais,tais como o xisto e as areias betuminosas, uma vez que as reservas provadas estão se esgotando,e (ii) o centro de gravidade da demanda por energia deverá se deslocar, principalmente, para a China, a Índia e o Oriente Médio [1].

Para se adaptar às mudanças citadas, as indústrias de extração, transporte e refino de óleo e gás enfrentarão desafios em um futuro próximo, tais como: (I) a extração de óleo das reservas não convencionais é muito mais complexa do que das originais; (II) a composição química do óleo não convencional é diferente do convencional - o primeiro é mais pesado, ou seja, é composto por cadeias de hidrocarbonetos mais longas e, portanto, exige maior fracionamento, o que gera mais gases poluentes e consome mais água e energia para tal - e (III) com as alterações nos centros de demanda de energia, novas rotas de distribuição deverão ser traçadas [1].

Muitas jazidas de petróleo e gás são encontradas em ambientes agressivos, às vezes inóspitos e ricos em $\mathrm{H}_{2} \mathrm{~S}$ (ambientes sour). Sendo bem conhecido como um veneno catódico, o $\mathrm{H}_{2} \mathrm{~S}$ é um dos principais contaminantes do óleo, e a sua presença em jazidas consiste em um grande desafio para a indústria de transporte de óleo e gás. $\mathrm{O}_{2} \mathrm{~S}$ facilita a entrada de hidrogênio atômico na estrutura do tubo de aço, o que leva a sua fragilização, entre outros danos, que podem ser catastróficos para a estrutura.

O impacto ambiental provocado pelo petróleo é inevitável e, infelizmente, não há previsão para a queda em seu consumo - na verdade, a meta de investimento financeiro e tecnológico em petróleo e gás natural é superior à de fontes renováveis, como mostra o"World 
Energy Outlook", publicado pela Agência Internacional de Energia em 2012 [2]. Portanto, todos os esforços devem ser direcionados para minimizar os danos ambientais inerentes ao uso destes combustíveis fósseis.

O desenvolvimento e a utilização de melhores aços para o transporte de óleo e de gás natural é uma das formas de se prevenir acidentes catastróficos para a natureza e para a humanidade, além de enormes prejuízos econômicos, e assim, reduzir o impacto ambiental.

Aços de alta resistência e baixa liga (High Strength Low Alloy, HSLA, em inglês) têm sido extensivamente utilizados para fabricação de dutos transportadores de petróleo e gás devido a suas propriedades, tais como, boa relação resistência/peso, alto limite de escoamento (275-450 MPa), tenacidade à fratura, resistência à fadiga, altas capacidades de trabalhabilidade e de soldabilidade [3,4]. O meio rico em $\mathrm{H}_{2} \mathrm{~S}$, ácidos e água, em que os recursos energéticos se encontram, acaba sendo prejudicial para estes aços: programas de inspeções indicam que fração considerável das falhas dos equipamentos usados na indústria do petróleo são atribuídas, em algum grau, a danos por hidrogênio [5]. Assim, outro requisito importante que esses materiais devem possuir é resistência à fragilização por hidrogênio, além da resistência à corrosão.

Os elementos de liga mais utilizados em aços HSLA são Mn, Nb, V, Ti, Mo, Ni e Cu; dentre eles, o Mn apresenta efeitos contraditórios para as propriedades mecânicas desses aços. Apesar de ser um elemento usado para aumentar a resistência do material pelo mecanismo de endurecimento por solução sólida, teores maiores do que 1,2\% em massa podem comprometer a resistência aos danos provocados pelo hidrogênio [6].

Recentemente foram desenvolvidas ligas com porcentagens de Mn muito menores do que as convencionais, em torno de 0,3\% em massa, gerando, assim, propriedades mais interessantes para aplicações em ambientes sour.[6]

Além do projeto de liga, uma série de práticas durante a fabricação e processamento dos novos aços vem sendo adotadas e são essenciais para o bom desempenho em ambientes sour [7].

Tendo em vista o que foi apresentado, pode-se dizer que a importância econômica atual e futura - do óleo e do gás, a demanda altíssima e crescente destes combustíveis, junto da necessidade extrema de se minimizar os impactos ambientaisocasionados por esta indústria, consistem em fortes justificativas para a condução do presente estudo. 


\section{Objetivos Gerais}

Comparar a difusividade do hidrogênio em dois aços para fabricação de tubos API 5L X65. O primeiro deles é um aço recentemente desenvolvido, com baixo teor de Mn e produzido especialmente para utilização em ambientes sour; o segundo é um aço comercial não sour, com alto teor de Mn. Verificar qual a influência de características microestruturais, como quantidade de contornos de grão e seu alinhamento, microconstituintes, textura e bandeamento na difusividade do hidrogênio através da técnica de permeabilidade ao hidrogênio.

\subsection{Objetivos Específicos}

Caracterizar os dois aços como recebidos em suas três seções, em relação ao sentido de laminação: longitudinal, transversal e do topo da chapa. Realizar medidas de permeabilidade ao hidrogênio para as três seções dos dois aços; depois, fazer medidas de metalografia quantitativa para todas as condições analisadas (tamanho de grão, fração volumétrica de microconstituintes e área de contorno de grão por unidade de volume). Verificar a presença de textura no aço com baixo Mn, por meio de Difração de Elétrons Retroespalhados (Electron Backscatter Diffraction, EBSD), e avaliar sua possível influência na difusividade efetiva do hidrogênio no aço. 


\section{Revisão Bibliográfica}

\subsection{Generalidades dos Aços de Alta Resistência e Baixa Liga, (High Strength Low Alloy, HSLA)}

Os aços HSLA são estudados há pelo menos 40 anos e, atualmente, representam 14\% de todos os aços produzidos mundialmente [8]. Possuem uma ampla gama de aplicações, desde folhas finas laminadas a quente para fabricação de carros, aços estruturais para a construção de navios, armações para prédios resistentes a terremotos, até barras de alta resistência para uso doméstico, como ferramentas de jardinagem. Em especial, estes aços são muito usados em oleodutos e gaseodutos pela indústria de transporte de óleo e gás natural [9].

O início da trajetória de desenvolvimento desta classe de materiais pode ser considerado nos anos 1900, por meio do projeto de aços de alta resistência e de aços laminados a quente que visavam à obtenção de boa resistência à tração [10]. O principal elemento de liga empregado era o $\mathrm{C}$, justamente pelo seu efeito de aumentar a resistência e por causa de seu baixo custo. Depois, em 1934, uma especificação para aços estruturais, introduzida pelo Reino Unido, fez com que o teor de C passasse a ser de, no máximo, 0,27\% e aumentou o teor de Mn para valores em torno de 1,5\%, ainda garantindo a sua boa resistência. No início dos anos 1950, devido à demonstração de seu efeito benéfico para propriedades como a tensão de escoamento e a temperatura de transição dúctil-frágil, começou a se trabalhar com refinamento de grão ferrítico [9,10]. Entre o final dos anos 1950, anos 1960 e 1970, já com base nos conhecimentos adquiridos sobre refino de grão, várias indústrias e pesquisadores passaram a identificar e explicar os mecanismos de endurecimento que atuavam sobre as ligas de Fe-C-Mn e a separar os efeitos das microadições no refino de grão e no endurecimento por precipitação [9]. Conforme as aplicações exigiam novas especificações, projetos de liga diferentes eram desenvolvidos e novas práticas de fabricação e de processamento eram realizadas. As necessidades de engenharia e as considerações econômicas impulsionaram e moldaram o desenvolvimento dos aços de alta resistência e baixa liga que conhecemos hoje [10].

Os principais procedimentos adotados, responsáveis pelas características conhecidas dos HSLA foram: (i) diminuiçãodos teores de $\mathrm{C}$ e de outros elementos de liga, como o Mn, além do controle da quantidade de elementos residuais; (ii) microadições de elementos de liga como o Nb, Ti e V; (iii) utilização dos processos de laminação a quente controlada, em que a 
etapa final da laminação se dá em temperatura próxima à $\mathrm{Ar}_{3}$; (iv) utilização de resfriamento acelerado e controlado após a laminação; (v) tratamentos de têmpera direta e de revenimento após a laminação controlada e (vi) controle do formato das inclusões [11].

A produção destes aços para a indústria de transporte de óleo e gás deve atender às especificações do American Petroleum Institute, ou seja, devem seguir a norma API 5L, de forma que sejam obtidas as melhores combinações possíveis de suas propriedades. Isto é conseguido através da otimização do projeto de liga e em conjunto com a utilização de processamento termomecânico controlado [6]. A classificação dos aços HSLA nos diferentes graus API 5L, como X65, X70, X80, etc, é feita com base nessa norma e significa que os aços são classificados em função do seu limite de escoamento mínimo. $O$ " $X$ " representa que o critério escolhido é o de escoamento, enquanto que o número corresponde aos dois primeiros dígitos da propriedade mecânica em questão, na unidade ksi (sistema inglês, equivale a 1000 lbf.in ${ }^{-2}$ ). Assim, o aço para tubo API 5L X65 tem limite de escoamento mínimo de 65 ksi, que equivalem a $448 \mathrm{MPa}[12,13]$.

$\mathrm{Na}$ composição química destes aços se tem, normalmente, teores de $\mathrm{C}$ variando de 0,02\% e 0,04\% a, no máximo, 0,2\% em massa. Os baixos teores de C são importantes para garantir a boa soldabilidade dos aços. Além de C, são adicionados teores menores do que 1,5\% de $\mathrm{Ni}, \mathrm{Cr}, \mathrm{Cu}$ e Mo e, tradicionalmente, teores de $\mathrm{Mn}$ entre $1 \%$ e 2\% em massa. Contudo, o que torna esta classe de aços especial são as microadições, ou seja, adição de teores que variam de $0,008 \%$ a $0,1 \%$ em massa, de $\mathrm{Nb}$, Ti e V (ocasionalmente pode-se adicionar Zr ou Ta) [9,14]. Estes elementos de liga são responsáveis pela formação de carbonetos e carbonitretos, que contribuem para o aumento da resistência dos aços através do mecanismo de endurecimento por precipitação, e, principalmente, participam do processo de refino dos grãos ferríticos, que é o fator mais importante para obtenção de alta resistência e tenacidade dos aços HSLA laminados [15]. De acordo com Cochrane [9], a adição de 0,02\% de $\mathrm{Nb}$, por exemplo, pode aumentar em $200 \mathrm{MPa}$ o limite de escoamento de um aço, em comparação com $1 \%$ de Ni que eleva a mesma propriedade em somente $38 \mathrm{MPa}$. Isto mostra a forte influência das microadições nas propriedades do aço [9]. Também são adicionados teores controlados de $\mathrm{Si}$, que promove a desoxidação e também endurecimento por solução sólida [11]. Outros elementos, como o $\mathrm{Ni}, \mathrm{Cr}, \mathrm{Cu}$ e Mo podem estar presentes na liga como resíduos dos minérios usados durante sua fabricação e/ou como adições para melhorar a sua resistência, porém, sempre respeitando o limite mencionado anteriormente (de até 1,5\%), para não comprometer a tenacidade, não aumentar em excesso a temperabilidade e prejudicar a 
soldabilidade do material [9,11]. Outro elemento de liga comum nestes aços, encontrado normalmente em teores baixos, em torno de $0,08 \%$, é o Al. Suas funções principais são promover a desoxidação do aço e refinar o grão ferrítico: um dos primeiros métodos usados para diminuição de tamanho de grão foi a adição de Al que, combinado com $\mathrm{N}$, forma partículas de AlN e estas, por sua vez, controlam o crescimento de grão da austenita em aços normalizados - papel similar ao dos $\mathrm{NbC}$, seus sucessores $[9,16]$. As partículas de AIN também minimizam o envelhecimento por deformação, contudo, o excesso de $\mathrm{Al}$ diminui a tenacidade do aço [11].

Os grupos de pesquisa do Laboratório de Transformações de Fase (LTF) e do Laboratório de Processos Eletroquímicos/LabH2S (LPE/LabH2S), ambos do Departamento de Engenharia Metalúrgica e de Materiais da EPUSP, além de outros autores do Brasil e do mundo, já descreveram exaustivamente diversos aspectos dos aços HSLA. Informações sobre a história de desenvolvimento destes aços, suas características gerais e efeitos de elementos de liga podem ser encontradas nos trabalhos de González [14,17], Ogata [18], Brandão [12] e Hincapie-Ladino [13]. Ainda, para maiores informações sobre a norma API 5L, podem ser consultados os trabalhos de Brandão [12] e Hincapie-Ladino [13], que contém excelentes revisões a respeito deste assunto.

Talvez a principal característica dos aços HSLA seja a sua microestrutura refinada, que garante a combinação de boa resistência mecânica e tenacidade. O refino dos grãos ocorre devido à utilização das microadições de elementos de liga, como já foi explicado, em conjunto com o processo termomecânico de laminação controlada (Thermomechanical Controlled Rolling, TMCR). Atualmente, com a evolução do TMCR e das práticas de fabricação do aço (steelmaking) - que envolvem, entre outros, o controle mais rigoroso dos teores de elementos de liga - são obtidos grãos com tamanhos que variam de 3 a $5 \mu \mathrm{m}$ [16].

Ainda, dependendo do grau API 5L do aço, podem ser encontrados os seguintes microconstituintes: ferrita e perlita, ferrita poligonal e ferrita acicular, ferrita acicular e bainita, ferrita acicular e microconstituinte martensita-austenita (normalmente chamado de microconstituinte MA) [6, 19]. A Tabela 1, traduzida e modificada de Stalheim et. al. [19], de Baker [20] e da norma API 5L [21] relaciona o grau do aço com o limite de escoamento e microestrutura típicos, juntamente da composição química convencional. 
Tabela 1. Grau API de aços, microestrutura correspondente e composição química convencional. Traduzido e modificado de [19-21].

\begin{tabular}{|c|c|c|c|}
\hline $\begin{array}{c}\text { Grau API } \\
5 \mathrm{~L}\end{array}$ & $\begin{array}{c}\text { Limite de } \\
\text { Escoamento } \\
(\mathrm{MPa})\end{array}$ & Microestrutura & Composição Química \\
\hline $\mathrm{X} 120$ & $\geq 883$ & $\begin{array}{c}\text { Ferrita acicular, bainita, } \\
\text { martensita }\end{array}$ & $\begin{array}{c}\mathrm{C}<0,10 ; \mathrm{Mn}<2,0 ; \\
\mathrm{Si}<0,40 ; \mathrm{Nb}<0,06 ; \\
(\mathrm{Cu}+\mathrm{Ni}+\mathrm{Cr}+\mathrm{Mo}+\mathrm{V}+\mathrm{B}) \leq \\
0,25\end{array}$ \\
\hline $\mathrm{X} 100$ & $\geq 690$ & Ferrita acicular, bainita & $\begin{array}{c}\mathrm{C}<0,06 ; \mathrm{Mn}<2,0 ; \\
\mathrm{Si}<0,40 ; \mathrm{Nb}<0,06 ; \\
(\mathrm{Cu}+\mathrm{Ni}+\mathrm{Cr}+\mathrm{Mo}+\mathrm{V}) \leq 0,23\end{array}$ \\
\hline$X 80$ & $>552$ & Ferrita ferrita & $\begin{array}{c}\mathrm{C} \leq 0,06 ; \mathrm{Mn}<1,70 \\
\mathrm{Si}<0,40 ; \mathrm{Nb} \leq 0,10 \\
(\mathrm{Cu}+\mathrm{Ni}+\mathrm{Cr}) \leq 0,18\end{array}$ \\
\hline$\Lambda 00$ & $=302$ & 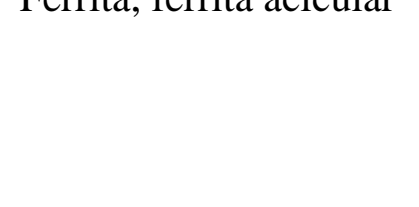 & $\begin{array}{c}\mathrm{C} \leq 0,06 ; \mathrm{Mn}<1,70 \\
\mathrm{Si}<0,40 ; \mathrm{Nb} \leq 0,10 \\
(\mathrm{Cu}+\mathrm{Ni}+\mathrm{Cr}) \leq 0,21\end{array}$ \\
\hline \multirow{4}{*}{$\mathrm{X} 70$} & \multirow{4}{*}{$\geq 483$} & \multirow[b]{2}{*}{ Ferrita, ferrita acicular } & $\begin{array}{l}\mathrm{C} \leq 0,06 ; \mathrm{Mn} \leq 1,65 \\
\mathrm{Si}<0,40 ; \mathrm{Nb} \leq 0,10\end{array}$ \\
\hline & & & $\begin{array}{c}\mathrm{C} \leq 0,06 ; \mathrm{Mn} \leq 1,65 \\
\mathrm{Si}<0,40 ;(\mathrm{Nb}+\mathrm{Mo}) \leq 0,18 \\
\text { ou }(\mathrm{Nb}+\mathrm{Mo}) \leq 0,21\end{array}$ \\
\hline & & \multirow[b]{2}{*}{ Ferrita, perlita } & $\begin{array}{l}\mathrm{C} \leq 0,10 ; \mathrm{Mn} \leq 1,65 \\
\mathrm{Si}<0,40 ; \mathrm{Nb} \leq 0,065\end{array}$ \\
\hline & & & $\begin{array}{c}\mathrm{C} \leq 0,10 ; \mathrm{Mn} \leq 1,65 ; \\
\mathrm{Si}<0,40 ;(\mathrm{Nb}+\mathrm{V}) \leq 0,15 \text { ou } \\
(\mathrm{Nb}+\mathrm{V}) \leq 0,20\end{array}$ \\
\hline
\end{tabular}


Tabela 1 (Continuação). Grau API de aço, microestrutura correspondente e composição química convencional. Traduzido e modificado de [19-21].

\begin{tabular}{|c|c|c|c|}
\hline $\begin{array}{c}\text { Grau API } \\
5 \mathrm{~L}\end{array}$ & $\begin{array}{c}\text { Limite de } \\
\text { Escoamento } \\
\text { (MPa) }\end{array}$ & Microestrutura & Composição Química \\
\hline \multirow[b]{2}{*}{ X65 } & \multirow[b]{2}{*}{$\geq 448$} & \multirow[b]{2}{*}{ Ferrita, perlita } & $\begin{array}{l}\mathrm{C} \leq 0,10 ; \mathrm{Mn} \leq 1,65 \\
\mathrm{Si}<0,40 ; \mathrm{Nb} \leq 0,065\end{array}$ \\
\hline & & & $\begin{array}{c}\mathrm{C} \leq 0,10 ; \mathrm{Mn} \leq 1,65 \\
\mathrm{Si}<0,40 ;(\mathrm{Nb}+\mathrm{V}) \leq \\
0,15 \text { ou } \\
(\mathrm{Nb}+\mathrm{V}) \leq 0,23\end{array}$ \\
\hline X65 sour & $\geq 448$ & Ferrita, perlita & $\begin{array}{c}\mathrm{C} \leq 0,05 ; \mathrm{Mn} \leq 1,35 \\
\mathrm{~S}<0,003 ; \mathrm{Si} \leq 0,30 \\
(\mathrm{Cu}+\mathrm{Ni}+\mathrm{Cr}) \leq 0,70 \\
\mathrm{Nb} \leq 0,065 \\
\text { ou }(\mathrm{Nb}+\mathrm{V}) \leq 0,15\end{array}$ \\
\hline X60 & $\geq 414$ & Ferrita, perlita & $\begin{array}{c}\mathrm{C} \leq 0,10 ; \mathrm{Mn} \leq 1,50 \\
\mathrm{Si} \leq 0,40 ; \mathrm{Nb} \leq 0,065 \text { ou } \\
(\mathrm{Nb}+\mathrm{V}) \leq 0,12\end{array}$ \\
\hline X60 sour & $\geq 414$ & Ferrita, perlita & $\begin{array}{c}\mathrm{C} \leq 0,05 ; \mathrm{Mn} \leq 1,20 \\
\mathrm{~S}<0,003 ; \mathrm{Si} \leq 0,30 \\
(\mathrm{Cu}+\mathrm{Ni}+\mathrm{Cr}) \leq 0,70 \\
\mathrm{Nb} \leq 0,065 \\
\text { ou }(\mathrm{Nb}+\mathrm{V}) \leq 0,12\end{array}$ \\
\hline X52 & $\geq 359$ & Ferrita, perlita & $\begin{array}{l}\mathrm{C} \leq 0,10 ; \mathrm{Mn} \leq 1,20 \\
\mathrm{Si} \leq 0,40 ; \mathrm{Nb} \leq 0,050\end{array}$ \\
\hline X52 sour & $\geq 359$ & Ferrita, perlita & $\begin{array}{c}\mathrm{C} \leq 0,05 ; \mathrm{Mn} \leq 1,10 \\
\mathrm{~S}<0,003 ; \mathrm{Si} \leq 0,30 \\
(\mathrm{Cu}+\mathrm{Ni}+\mathrm{Cr}) \leq 0,60 \\
\mathrm{Nb} \leq 0,050 \\
\text { ou }(\mathrm{Nb}+\mathrm{V}) \leq 0,10\end{array}$ \\
\hline X42 & $\geq 290$ & Ferrita, perlita & $\begin{array}{l}\mathrm{C} \leq 0,10 ; \mathrm{Mn} \leq 1,00 \\
\mathrm{Si} \leq 0,40 ; \mathrm{Nb} \leq 0,050\end{array}$ \\
\hline
\end{tabular}




\subsection{Método termomecânico de laminação controlada, (TMCR)}

O método termomecânico de laminação controlada pode ser definido, de maneira simples, como uma sequência de estágios de laminação a quente, em temperaturas definidas, interrompidos por períodos de resfriamento e, ao fim das etapas de laminação, de resfriamento ao ar ou resfriamento em linhas d'água [22].

O principal objetivo deste tratamento é o de reduzir o tamanho de grão da austenita e, consequentemente, refinar os grãos ferríticos. Nos HSLA existem diversos mecanismos de aumento de resistência atuando em conjunto, como: (a) de endurecimento por solução sólida substitucional; (b) endurecimento por precipitação de carbonetos, carbonitretos, etc; (c) transformação de fase, como a martensítica e a bainítica; (d) aumento de densidade de discordâncias, decorrente de processos de deformação e também de transformações de fase e (e) refino de grão e formação de subgrãos. Esse último mecanismo é o único que promove o aumento da resistência mecânica e, ao mesmo tempo, da tenacidade do material (outras propriedades como a soldabilidade e a plasticidade também são favorecidas); todos os demais, se não forem cuidadosamente controlados, levarão, em algum momento, à fragilização do aço. $[16,18,22,23,24,25]$.

A eficiência de refino de grão é mais elevada quando se utiliza o TMCR do que outros métodos, como a laminação a quente convencional seguida de normalização ou de têmpera e revenimento. A grande vantagem do TMCR, em comparação com processos de laminação convencionais, é que se tem o aumento da densidade de sítios de nucleação de ferrita nos grãos de austenita, antes e durante a transformação $\gamma \rightarrow \alpha$. Isso é feito através do controle das condições de laminação e de microadições de elementos de liga, como o Nb [23,24]. Os papéis das temperaturas de laminação e das microadições são apresentados detalhadamente do Anexo A.

\subsection{HSLA na indústria de transporte de óleo e gás}

Os requisitos básicos que os aços HSLA devem possuir para aplicação como dutos transportadores de óleo e gás são: (i) alta resistência, principalmente quando usados abaixo do nível do mar e para suportar pressões de transmissão muito elevadas; (ii) soldabilidade, uma vez que os tubos são soldados e a região da solda, geralmente, pode concentrar defeitos e iniciar o trincamento do tubo; (iii) tenacidade à fratura; (iv) resistência ao trincamento 
induzido por hidrogênio, entre outros danos originados de interações de hidrogênio atômico com o aço; (v) resistência à corrosão sob tensão e (vi) resistência à fadiga [6].

Segundo Stalheim [19], as condições climáticas, ambientais e do próprio óleo e gás natural encontrados nas reservas não convencionais requerem atributos especiais, alguns já mencionados no parágrafo anterior, e que geram implicações na produção dos dutos transportadores. A Tabela 2, retirada de [19], lista os principais requisitos e as implicações provocadas na produção dos aços.

Tabela 2. Requisitos especiais que os aços para oleodutos devem possuir, para conseguirem suportar as condições mais agressivas e extremas de serviço, e a implicação destas necessidades na produção dos aços. Traduzido de [19].

\begin{tabular}{|c|c|}
\hline Requisitos & Implicação na Produção dos Aços \\
\hline Suportar maiores pressões de operação & $\begin{array}{c}\text { Elevação da resistência do tubo e/ou } \\
\text { espessura maior. A tenacidade à fratura } \\
\text { pode ser comprometida e os custos do } \\
\text { material se tornarão mais elevados, devido } \\
\text { aos elementos de liga que serão } \\
\text { necessários (microadições e/ou adições de } \\
\qquad \mathrm{Cu}, \mathrm{Ni}, \mathrm{Cr}, \mathrm{Mo}) \text {. }\end{array}$ \\
\hline $\begin{array}{c}\text { Trabalho em ambientes com temperaturas } \\
\text { baixas }\end{array}$ & $\begin{array}{l}\text { Alta tenacidade à fratura em temperaturas } \\
\text { subzero. Altos níveis de energia } \\
\text { necessitam de aços muito limpos (boas } \\
\text { práticas de fabricação dos aços), controle } \\
\text { do formato das inclusões, baixos teores de } \\
\text { C, S, P. }\end{array}$ \\
\hline Estabilidade do solo & $\begin{array}{l}\text { Projeto baseado na deformação, deve } \\
\text { possuir resistência a tensões longitudinais } \\
\text { mais elevada; precisa suportar maiores } \\
\text { alongamentos uniformes,característica que } \\
\text { não é, necessariamente, compatível com o } \\
\text { projeto de microestrutura para se obter } \\
\text { resistência a tensões mais elevadas. }\end{array}$ \\
\hline
\end{tabular}


Tabela 2. (Continuação) Requisitos especiais que os aços para oleodutos devem possuir, para conseguirem suportar as condições mais agressivas e extremas de serviço, e a implicação destas necessidades na produção dos aços. Traduzido de [19].

\begin{tabular}{|c|c|}
\hline Uso de solda mecanizada & $\begin{array}{l}\text { Diminuição do carbono equivalente } \\
\text { (CE/Pcm), que pode levar a diferentes } \\
\text { projetos de liga e pouca variação nos } \\
\text { valores de resistência alcançados, } \\
\text { aumentando o custo de produção. }\end{array}$ \\
\hline $\begin{array}{c}\text { Resistência ao trincamento induzido } \\
\text { por hidrogênio (ambientes de serviço } \\
\text { sour) }\end{array}$ & $\begin{array}{l}\text { Baixos teores de carbono e aumento das } \\
\text { microadições/adições de elementos de } \\
\text { liga para manter a resistência } \\
\text { mecânica. Os aços devem ter } \\
\text { microestruturas muito limpas (obtidas } \\
\text { por meio de ótimas práticas de } \\
\text { fabricação dos aços), controle do } \\
\text { formato de inclusões, teores muito } \\
\text { baixos de S e de P. Controle ótimo de } \\
\text { segregação de elementos de liga durante } \\
\text { a fundição. Custos mais altos associados } \\
\text { ao projeto de liga e processamento do } \\
\text { aço. }\end{array}$ \\
\hline Operações offshore & $\begin{array}{c}\text { Projeto baseado para suportar } \\
\text { deformações, resistir a tensões } \\
\text { lonigitudinais mais elevadas, redução da } \\
\text { anisotropia - potencial necessidade de } \\
\text { elementos de liga adicionais, aumentando } \\
\text { o custo de produção. }\end{array}$ \\
\hline
\end{tabular}

Dentre os requisitos listados, a resistência ao trincamento induzido por hidrogênio é o de maior relevância para o presente trabalho. Quando se fala em serviço em ambiente sour, os danos provocados pelo hidrogênio consistem no tema mais importante e que gera mais desafios tecnológicos para os produtores de aços e para a indústria de transporte de óleo e gás, pois podem levar a falhas inesperadas e catastróficas [26]. 
Como mostrado pela Tabela 2 e em concordância com outros autores $[6,7,16,26]$, a resistência aos danos provocados pelo hidrogênio depende fortemente da microestrutura do aço, de sua composição química, da morfologia e distribuição de inclusões não metálicas e, consequentemente, das práticas adotadas durante a sua fabricação e processamento. Como os tubos são soldados, na maior parte das vezes, é essencial que o teor de C seja baixo para garantir a boa soldabilidade, além de evitar a segregação deste elemento de liga. A Tabela 1 mostra que as faixas de composição química dos aços sour têm teores de C inferiores ou iguais a 0,05\% em massa. As microadições de elementos de liga, e outras macroadições, promovem o aumento da resistência mecânica do aço no lugar do C, mantendo a sua boa tenacidade. A diminuição do teor de Mn tem se mostrado uma excelente estratégia para se reduzir a segregação de elementos de liga em linha central. Além disso, com o decréscimo dos teores de Mn e de S, a formação de inclusões do tipo MnS é evitada. Segregação de elementos de liga, formação de bandas microestruturais (em decorrência da segregação) e inclusões correspondem aos principais fatores microestruturais que prejudicam a resistência aos danos provocados pelo hidrogênio de um aço.

Outro aspecto que deve ser levado em consideração é o teor de H dissolvido na chapa de aço antes do processamento a quente, proveniente das etapas de fabricação do aço. Este teor deve ser o mínimo possível para que o risco de danos por $\mathrm{H}$ seja reduzido em serviço [27]. A solubilidade do $\mathrm{H}$ no aço diminui com a redução da temperatura e com as transformações alotrópicas do ferro. A Figura 1 abaixo, adaptada de [27], mostra a variação da solubilidade do $\mathrm{H}$ no ferro em função da temperatura.

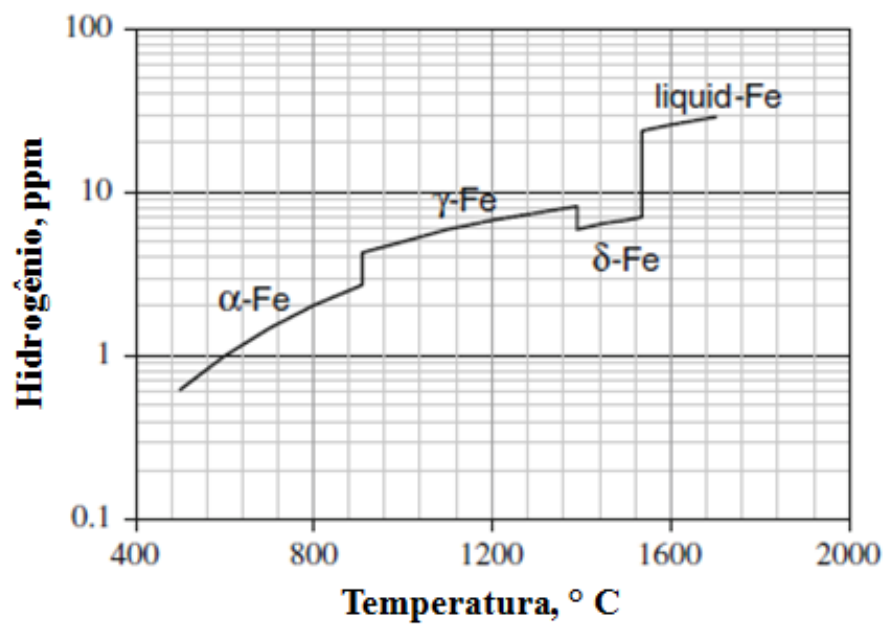

Figura 1. Solubilidade estimada do hidrogênio no ferro, em função da temperatura e das transformações alotrópicas do ferro puro, para pressão parcial de $\mathrm{H}_{2}$ de $1 \mathrm{~atm}$ e temperaturas superiores a $400{ }^{\circ} \mathrm{C}$. Modificado de [27]. 
Durante a solidificação, se a chapa de aço recém-produzida for resfriada muito rapidamente, o $\mathrm{H}$ em seu interior não terá tempo para se difundir e abandonar a estrutura metálica completamente, uma vez que a difusividade se torna mais lenta com a redução da temperatura. Portanto, além de ser necessário minimizar a entrada de $\mathrm{H}$ no aço durante as etapas de sua fabricação, é preciso controlar a taxa de resfriamento de forma adequada [27].

A Tabela 3 resume algumas práticas adotadas durante a fabricação de aços grau X52 e X65 para uso em meios sour [7,27].

Tabela 3. Métodos especiais usados para fabricação de aços grau X52 e X65 sour [7,27].

\begin{tabular}{|c|c|}
\hline Prática & Objetivo \\
\hline $\begin{array}{l}\text { Resfriamento controlado, após fundição, } \\
\text { por período mínimo de } 48-72 \mathrm{~h} \text {. }\end{array}$ & $\begin{array}{c}\text { Remoção de H atômico em solução sólida } \\
\text { com o aço. }\end{array}$ \\
\hline $\begin{array}{l}\text { Uso de ferro obtido por redução direta } \\
\text { (DRI, direct-reduced iron) como matéria } \\
\text { prima para fabricação do aço. }\end{array}$ & $\begin{array}{c}\text { Garantir que os teores de } \mathrm{S} \text { e de } \mathrm{P}, \\
\text { elementos de liga que tendem a sofrer } \\
\text { segregação, sejam baixos e, } \\
\text { consequentemente, que o aço produzido } \\
\text { seja limpo }\end{array}$ \\
\hline $\begin{array}{l}\text { Tratamento do aço em seu estado ainda } \\
\text { líquido com cálcio metálico. }\end{array}$ & $\begin{array}{l}\text { Controle do formato das inclusões de } \\
\text { sulfeto e de óxidos - para que fiquem } \\
\text { arredondadas, de pequenas dimensões e } \\
\text { não sofram deformação durante o } \\
\text { processamento a quente. O uso de cálcio } \\
\text { metálico garante que o tratamento seja } \\
\text { livre de umidade e, assim, minimiza a } \\
\text { entrada de } \mathrm{H} \text {. }\end{array}$ \\
\hline $\begin{array}{c}\text { Desgaseificação a vácuo pelo método RH } \\
\text { (Rurhstahl Heraeus). }\end{array}$ & $\begin{array}{l}\text { Remoção de } \mathrm{H} \text { e de } \mathrm{N} \text { em solução e } \\
\text { controle do superaquecimento do aço } \\
\text { fundido, que influencia significativamente } \\
\text { na segregação de elementos de liga. }\end{array}$ \\
\hline Uso de teores baixos de C, Mn, S e P. & $\begin{array}{c}\text { Garantir que a segregação de elementos de } \\
\text { liga seja baixa. }\end{array}$ \\
\hline $\begin{array}{l}\text { (1) Uso de baixo superaquecimento } \\
\text { (menor do que } 25^{\circ} \mathrm{C} \text { ) e velocidade de }\end{array}$ & $\begin{array}{l}\text { Minimização de cavidades de } \\
\text { encolhimento. Estas se formam na }\end{array}$ \\
\hline
\end{tabular}




\begin{tabular}{|c|c|}
\hline $\begin{array}{c}\text { fundição baixa; (2) uso do método de } \\
\text { Dynamic Soft Reduction. }\end{array}$ & $\begin{array}{c}\text { microestrutura a partir do encolhimento } \\
\text { do material, decorrente do processo de } \\
\text { solidificação. }\end{array}$ \\
\hline
\end{tabular}

Atualmente, os aços comerciais usados neste tipo de aplicação possuem dois projetos de microestrutura básicos, de ferrita/perlita e de ferrita/ferrita acicular, e os graus API 5L vão até o X80 [16, 19]. Aços com graus X100 e X120 vêm sendo desenvolvidos e estudados, também, para uso em ambientes sour, tendo microestrutura constituída de ferrita/ferrita acicular/bainita e, às vezes, com martensita junto desses outros três microconstituintes [28, 19]. Em alguns casos também são encontrados os microconstituintes MA (martensitaaustenita), porém, em fração volumétrica muito baixa [5]. As Figuras de 2 a 6 contêm exemplos de microestruturas de diferentes aços sour para oleodutos/gaseodutos, retiradas de diversos artigos pesquisados.

As Figuras 2A e 2B, retiradas de [29], apresentam as microestruturas de dois aços grau X52: um usado comercialmente para transporte local de gás sour (Figura 2A) e outro em estágio experimental, que tem a particularidade de não apresentar junta soldada (Figura 2B). Cada tubo foi fornecido por uma empresa e as diferenças em suas composições químicas e nos parâmetros de fabricação e processamento levaram às microestruturas distintas. $\mathrm{O}$ aço da Figura 2A é composto, basicamente, por ferrita e perlita e o da Figura 2B, por ferrita acicular refinada [29].


Figura 2. Micrografias ópticas de dois tubos X52, fornecidos por diferentes empresas. (A) Microestrutura de tubo usado comercialmente em ambientes sour, composta por ferrita (claro) e perlita (escuro). (B) Microestrutura de tubo em estágio experimental, composta por ferrita acicular refinada. Aumento não informado pelo autor. Retirado de [29]. 
A Figura 3 mostra as microestruturas de dois aços para tubo X60, como laminados, produzidos e processados pela mesma empresa (mesmas práticas de fabricação e de processamento), porém com composições químicas diferentes. O aço representado pela Figura 3A é constituído por $79 \%$ de ferrita, $21 \%$ de perlita e em torno de $1 \%$ do microconstituinte MA; já o aço da Figura 3B possui 95\% de ferrita, 3\% de perlita e 2\% de microconstituinte MA [5].
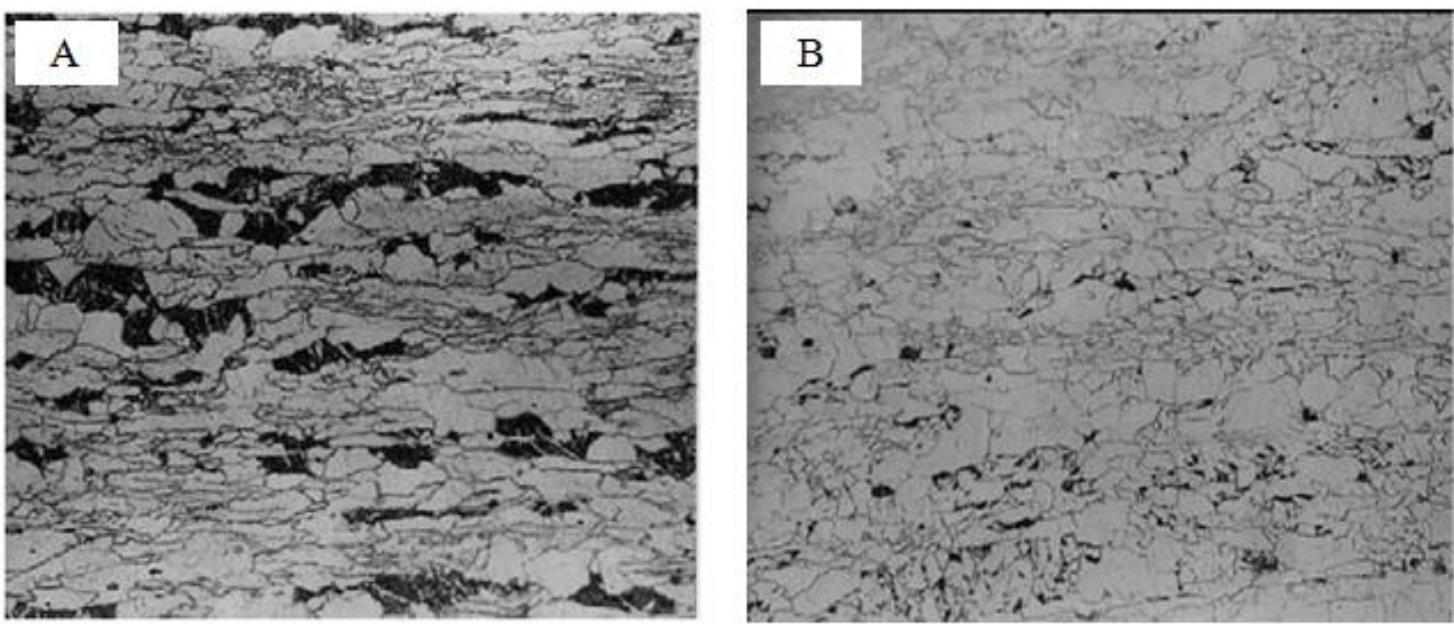

Figura 3. Micrografias ópticas de dois aços para tubos X60, do mesmo fabricante e com composições químicas diferentes. (A) Microestrutura composta por $79 \%$ de ferrita e 21\% de perlita, (B) Microestrutura composta por $95 \%$ de ferrita e $3 \%$ de perlita. Aumento de 500 x. Retirado de [5].

A Figura 4 apresenta a microestrutura de um tubo X65 sour, estudado por Fallahmohammadi et. al. [30], que passou pelos tratamentos de têmpera e revenimento, após a laminação e antes de sua construção. De acordo com os autores, e como se pode observar pela Figura 4, a microestrutura é composta por ferrita equiaxial e ferrita acicular. A Figura 5 apresenta uma micrografia de elétrons secundários retirada de outro trabalho deste mesmo grupo de pesquisa [31], na qual se podem ver finos precipitados, de cor branca, ao longo dos contornos de grão de ferrita. Estes carbonetos foram obtidos durante a etapa de revenimento e só podem ser observados em grandes aumentos, devido a suas pequenas dimensões. 


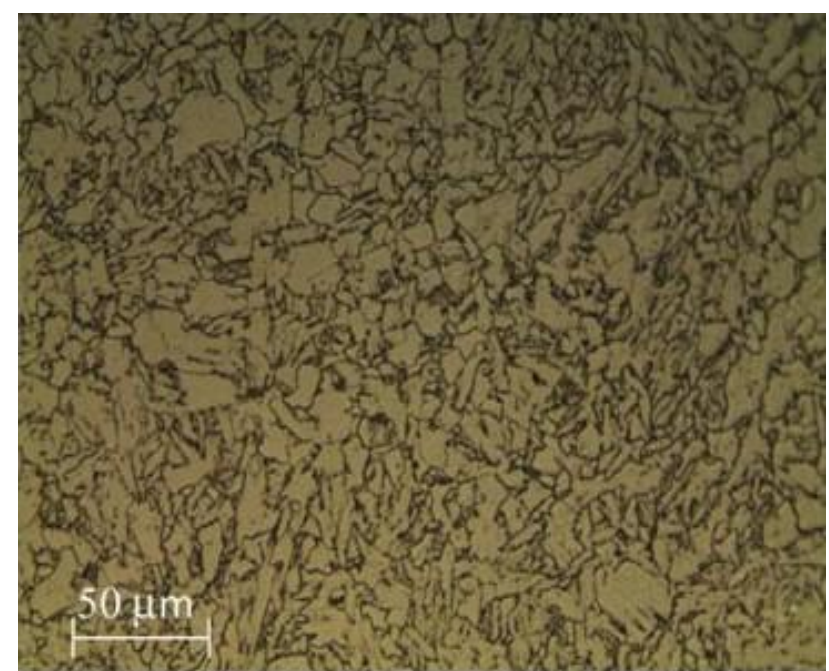

Figura 4. Microestrutura de amostra de um tubo API X65 sour, composta por ferrita equiaxial e ferrita acicular. Aumento não informado pelo autor. Retirado de [30].

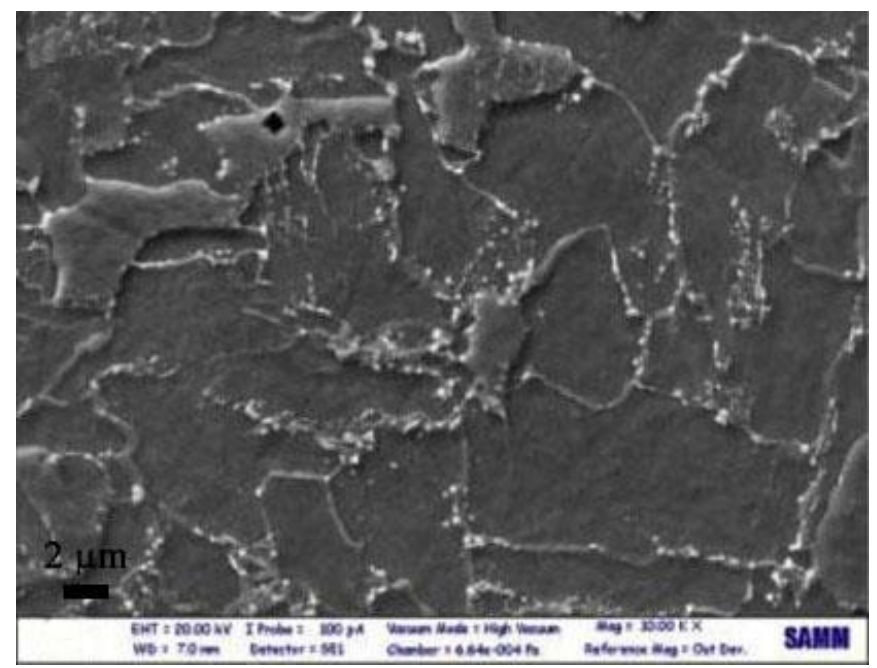

Figura 5. Micrografia de elétrons secundários do aço X65 após revenimento, mostrando carbonetos (brancos) precipitados preferencialmente nos contornos de grão. Aumento de 10000 x. Retirada de [31].

A Figura 6, retirada do trabalho de Haq et. al. [32], apresenta micrografias de dois aços grau X70, com diferentes teores de $\mathrm{Mn}$ - na Figura 6A se tem a microestrutura do aço com 1,14\% em massa de Mn e na Figura 6B, o aço com 0,5\% em massa de Mn. Nas duas microestruturas é possível observar a presença de ferrita (matriz) e perlita (escura) [32]; na Figura 6A nota-se que as colônias de perlita se mostram maiores do que na Figura 6B e, no topo da Figura 6A, observa-se o que pode ser uma banda de perlita. A estrutura de banda pode ser formada por conta de segregação de Mn, entre outros elementos de liga, no aço. 

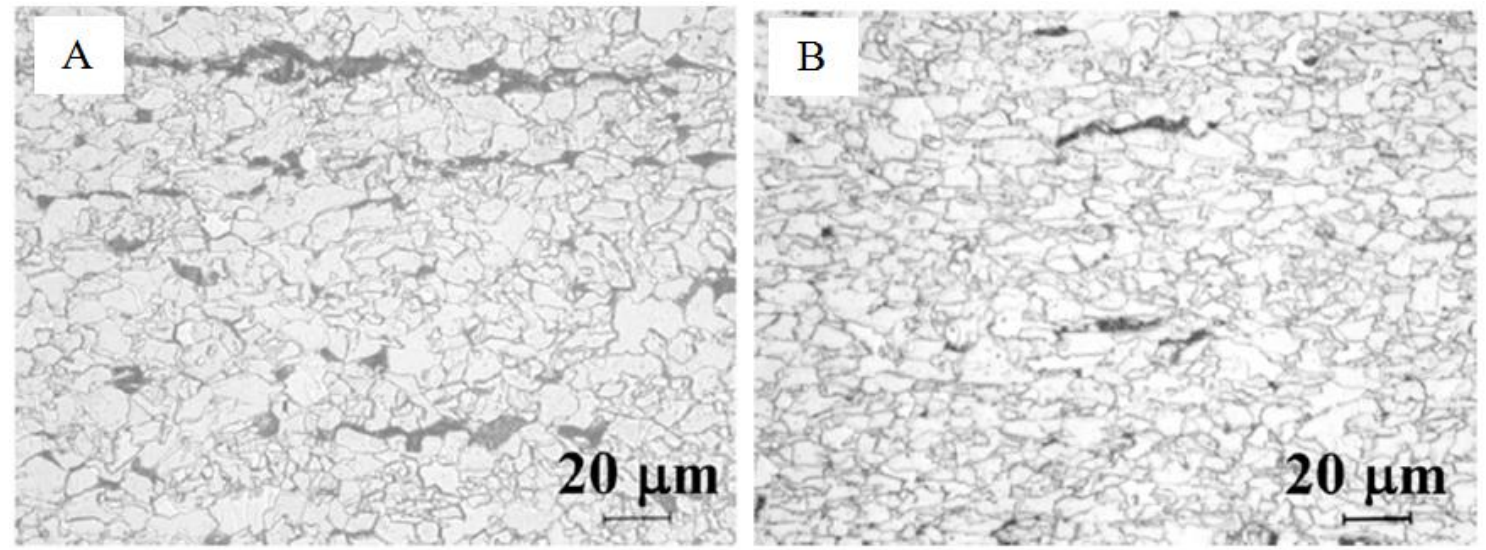

Figura 6. Microestruturas de dois aços HSLA grau X70, com diferentes teores de Mn. (a) 1,14\% em massa de Mn e (b) 0,5\% em massa de Mn. Aumento não informado pelo autor.Imagens retiradas de [32].

A Figura 7, proveniente do trabalho de Sha e Li [33], apresenta a microestrutura de um aço para tubo X80 experimental, com baixo teor de Mn. O material não contém bandas de microconstituintes (diminuição do teor de elementos de liga que provocam segregação, assim como no caso do X70 da Figura 6B) e é formado, principalmente, por ferrita acicular (AF), bainita granular (GB) e microconstituinte MA [33].

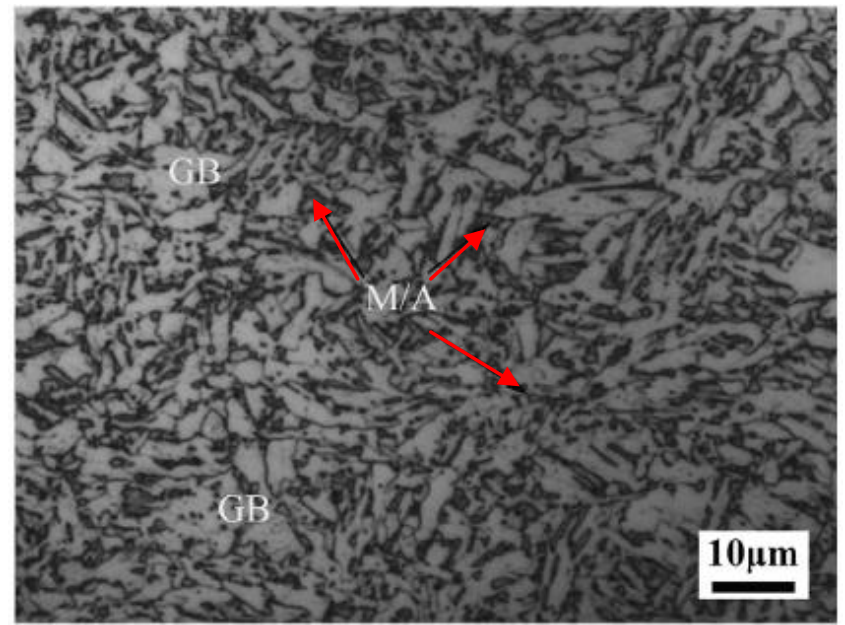

Figura 7. Microestrutura de aço HSLA grau X80; setas vermelhas indicam o microconstituinte MA e as regiões identificadas por GB correspondem à bainita granular. Aumento não informado pelo autor. Imagem retirada de [33].

Já a Figura 8 mostra a microestrutura de um aço na forma de tubo API X100, com alto Mn. Na imagem, as áreas escuras correspondem à martensita e as regiões claras a colônias de ferrita e de bainita [34]. 


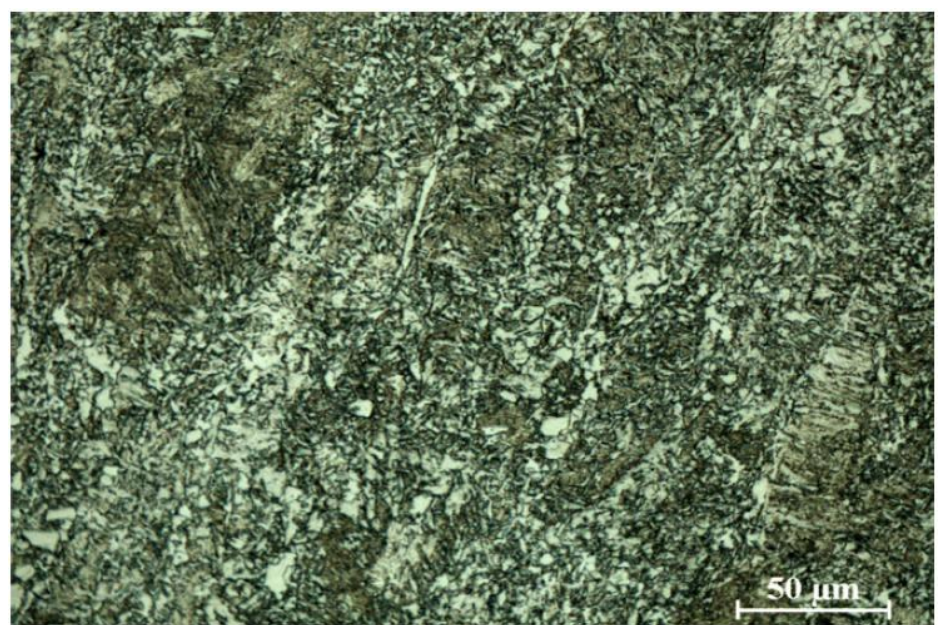

Figura 8. Microestrutura de tubo API X100. Aumento não informado pelo autor. Imagem retirada de [34].

Apesar de serem objetos de pesquisa e desenvolvimento, os aços para tubos API X100 e X120 ainda não têm ampla aplicação pela indústria de transporte de óleo e gás como os outros graus mais baixos. Alguns oleodutos do grau X100 foram instalados no Sistema Trans Canada, porém operando sob tensões muito abaixo de sua capacidade [35].

Um obstáculo à utilização destes graus mais elevados em aplicações sour é que a suscetibilidade aos danos por hidrogênio tende a aumentar com o grau do aço, devido à presença de fases mais duras na microestrutura, como a bainita e a martensita [36]. Assim, o desafio tecnológico destes aços e o que motiva muitas pesquisas atuais, é combinar os elevados valores de resistência mecânica associados a esses graus com excelente resistência aos danos provocados pelo hidrogênio [36]. Um exemplo disso é que os aços para tubos API X100 e X120 vêm sendo considerados para a construção de gaseodutos no Ártico [37]. Além das condições ambientais extremas, os aços devem suportar altas pressões gasosas, ou seja, devem apresentar alta resistência mecânica e, além disso, ter boa resistência à corrosão, uma vez que com o aumento das pressões de trabalho se tem o aumento da suscetibilidade à corrosão sob tensão assistidas por gases, como o $\mathrm{H}_{2} \mathrm{~S}$ [37].

\subsection{Ambientes sour e a fragilização por hidrogênio}

Até o momento, muito se falou da importância da resistência aos danos provocados pelo hidrogênio e das características favoráveis que os aços devem possuir para alcançarem esta propriedade, no entanto, não foi explicado o porquê dessa necessidade. O presente tópico explica como o hidrogênio entra na estrutura do aço, o que acontece no interior do material e qual o efeito da entrada deste elemento nas propriedades do aço. 
Primeiro, a superfície do aço é exposta ao ambiente ácido e sour, rico em $\mathrm{H}_{2} \mathrm{~S}$. A partir disso, se dá a corrosão do Fe, de acordo com o conjunto de Reações 1-3 (Reações 1 e 2 são as parciais e a Reação 3 é a global) [28]:

$$
\begin{gathered}
\mathrm{Fe} \rightarrow \mathrm{Fe}^{2+}+2 e^{-} \text {(anodo) } \\
2 \mathrm{H}^{+}+2 e^{-} \rightarrow 2 H_{a t} \text { (catodo) } \\
\mathrm{Fe}+\mathrm{H}_{2} \mathrm{~S} \rightarrow \mathrm{FeS}+2 \mathrm{H}_{a t}(\text { global })
\end{gathered}
$$

Outros ácidos presentes no meio de trabalho podem levar à corrosão do Fe, junto do $\mathrm{H}_{2} \mathrm{~S}$. Na presença de $\mathrm{H}_{2} \mathrm{~S}$, a corrosão do Fe é acompanhada da formação de uma camada fina de sulfeto na superfície do aço, que torna o processo mais complexo. Esta camada de sulfeto pode alterar a taxa de corrosão do aço, dependendo de fatores como a pressão parcial de $\mathrm{H}_{2} \mathrm{~S}$, a temperatura e o $\mathrm{pH}$ do meio - quanto maior o $\mathrm{pH}$, maior é a taxa de formação da camada de sulfeto de ferro. Existem dois trabalhos de Zhou C et. al., entre outros, que tratam com mais detalhes essas questões [38, 39].

Os átomos de $\mathrm{H}$ produzidos pela Reação (3), inicialmente adsorvidos pela superfície metálica, podem se recombinar e formar gás $\mathrm{H}_{2}$ que é liberado para a atmosfera e não provoca nenhum dano ao aço (Reação 4) [12, 13, 16, 17, 28]:

$$
H_{a t}+H_{a t} \rightarrow H_{2}
$$

Todavia, o $\mathrm{H}_{2} \mathrm{~S}$, conhecido por ser um veneno catódico, retarda o processo expresso pela Reação 4, diminuindo a sua taxa, e fazendo com que parte do $\mathrm{H}_{\mathrm{at}}$ produzido entre e se difunda na estrutura metálica. A Reação 4 pode ser, então, reescrita da seguinte forma:

$$
\mathrm{H}_{\mathrm{at}}+\mathrm{H}_{\mathrm{at}} \stackrel{\mathrm{H}_{2} \mathrm{~S}}{\longrightarrow} \mathrm{H}_{2}
$$

A esquematização da Figura 9 ilustra o processo descrito.

Uma vez no interior da estrutura do aço, os átomos de $\mathrm{H}$ se difundem rapidamente, mesmo em baixas temperaturas, devido ao seu tamanho extremamente pequeno e à presença de gradiente de concentração através da estrutura metálica [12, 13, 16, 17]. No entanto, 
mesmo com a facilidade que o $\mathrm{H}$ tem para se difundir, as características microestruturais dos aços afetam a sua mobilidade, tornando a difusão mais lenta. Por esse motivo, o H não apresenta a sua difusividade de rede, $\mathrm{D}_{1}$ (lattice diffusivity), e sim a chamada difusividade efetiva, $\mathrm{D}_{\text {eff }}$ (effective diffusivity), que leva em conta a presença de todos os obstáculos ao movimento atômico do $\mathrm{H}[40,41]$.

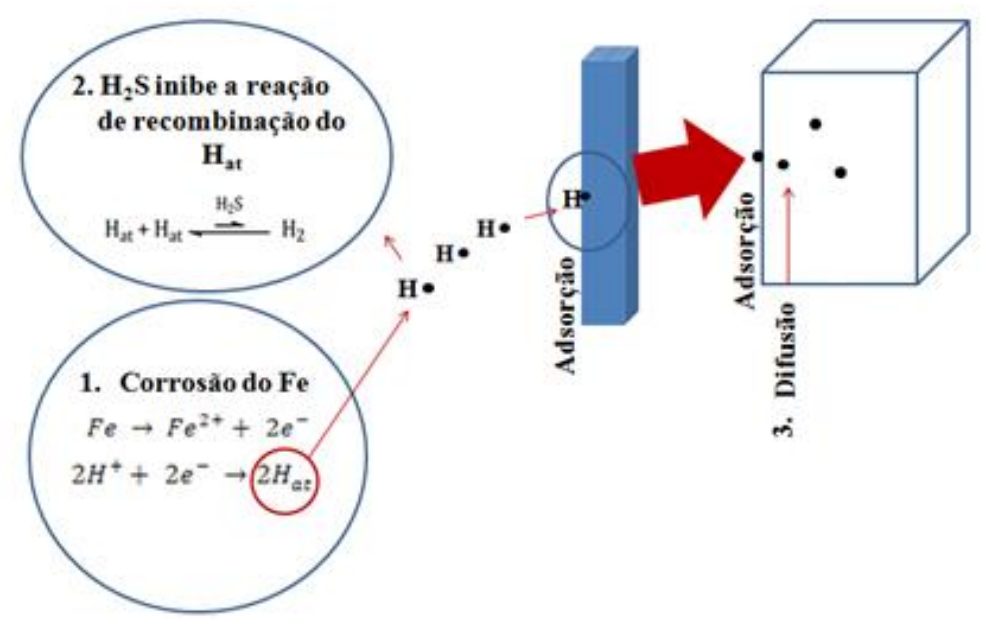

Figura 9. Esquematização que mostra o processo de entrada de $\mathrm{H}$ atômico na estrutura do aço, em meio sour.

Os microconstituintes presentes, os contornos de grão, a presença de lacunas e de discordâncias, interfaces com inclusões não metálicas, precipitados e átomos substitucionais podem atuar como armadilhas (traps), ou sítios de aprisionamento de hidrogênio [32, 42, 43]. Caso não existissem os traps, o $\mathrm{H}$ migraria pela estrutura através de saltos aleatórios nas posições intersticiais e o tempo de residência dos átomos de $\mathrm{H}$ em cada posição seria muito curto [42].

Quando aprisionados no interior dos aços, os átomos de $\mathrm{H}$ podem se recombinar, formando bolhas de $\mathrm{H}_{2}$ (blisters), outros produtos gasosos, hidretos, soluções sólidas, entre outros [43]. Estes compostos podem induzir a degradação de suas propriedades mecânicas sem levá-lo à fratura, ou seja, fragilizam o material, ou podem provocar trincas. $\mathrm{O}$ trincamento é mais facilmente iniciado em regiões com concentradores de tensão, como microconstituintes de alta dureza e inclusões não metálicas. Na presença de tensões, aplicadas ou residuais, a falha pode acontecer tanto por corrosão sob tensão assistida por sulfeto (Sulfide Stress Corrosion Cracking - SSCC) ou por trincamento induzido pelo hidrogênio orientado sob tensão (Stress Oriented Hydrogen Induced Cracking - SOHIC) [5]. 


\subsection{Sítios de aprisionamento de hidrogênio (traps)}

Os sítios de aprisionamento de $\mathrm{H}$ são classificados de maneira simplificada pela norma ASTM G148-97 [40] como reversíveis ou irreversíveis, dependendo basicamente de dois parâmetros que, entre si, são diretamente proporcionais: (1) o valor da energia de ligação $\mathrm{E}_{\mathrm{B}}$ do trap com o átomo de $\mathrm{H}$, em relação à energia normal de difusão pela rede e (2) o tempo de permanência do átomo de $\mathrm{H}$ no sítio, em comparação com a escala de tempo do teste de permeabilidade ao $\mathrm{H}$, ensaio discutido detalhadamente na seção 3.7 do presente texto [40,41]. Quando a energia de ligação é baixa e, consequentemente, o tempo de permanência do $\mathrm{H}$ no sítio é relativamente curto, o trap é classificado como reversível. Quando a energia de ligação é alta e o tempo de residência do H é infinito ou muito longo, o trap é chamado de irreversível [40]. Contornos de grãos, discordâncias, e átomos substitucionais são exemplos de traps reversíveis; inclusões não metálicas e precipitados são exemplos de traps irreversíveis [13, $32,41]$.

Outro parâmetro que também auxilia na caracterização e classificação dos traps é a energia de ativação do trap $\mathrm{E}_{\mathrm{aT}}$, que corresponde à energia necessária para que um átomo de $\mathrm{H}$ se desprenda de um sítio de aprisionamento e migre para um sítio normal da rede cristalina. Lee e Lee [44] fizeram um tratamento matemático detalhado para determinar os valores de $E_{a T}$ e $E_{B}$, a partir de curvas obtidas por análise de dessorção térmica. Para entender melhor o que são essas energias, é apresentado abaixo na Figura 10 um modelo que representa os níveis de energia do hidrogênio em torno de um sítio de aprisionamento [44].

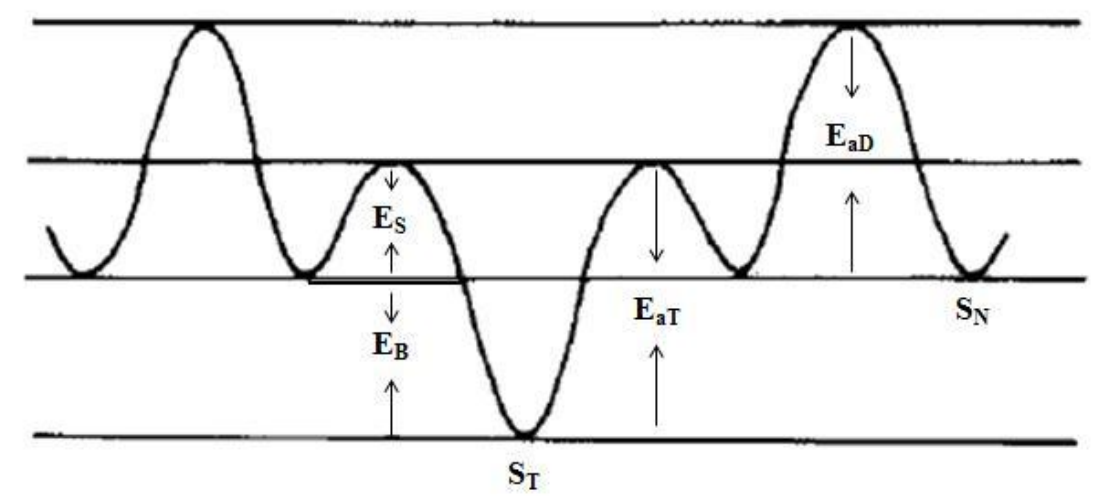

Figura 10. Níveis de energia adquiridos pelo hidrogênio em torno de um trap. Na figura, $\mathrm{E}_{\mathrm{S}}=$ energia de ativação necessária para migração de um átomo de $\mathrm{H}$ a partir de um sítio da rede cristalina para um trap; $\mathrm{E}_{\mathrm{B}}=$ energia de ligação do átomo de $\mathrm{H}$ com o trap; $\mathrm{S}_{\mathrm{T}}=$ energia do átomo de $\mathrm{H}$ no trap; $\mathrm{E}_{\mathrm{aT}}=$ energia de ativação para que o átomo de $\mathrm{H}$ escape do trap $; \mathrm{E}_{\mathrm{aD}}=$ energia de ativação para que o átomo de $\mathrm{H}$ se difunda pela rede cristalina e $\mathrm{S}_{\mathrm{N}}=$ energia do átomo de $\mathrm{H}$ em um sítio intersticial da rede. Modificado de [44]. 
Na Figura 10, E $E_{S}$ corresponde à energia de ativação necessária para que um átomo de $\mathrm{H}$ se desprenda de um sítio da rede cristalina e transite para um trap; $\mathrm{E}_{\mathrm{B}}$ é a energia de ligação do átomo de $\mathrm{H}$ com o trap; $\mathrm{S}_{\mathrm{T}}$ é a energia no trap; $\mathrm{E}_{\mathrm{aT}}$ é a energia de ativação para que o $\mathrm{H}$ escape do trap; $\mathrm{E}_{\mathrm{aD}}$ é a energia de ativação para que o $\mathrm{H}$ se difunda pelos sítios da rede cristalina e $S_{N}$ é a energia de um sítio da rede cristalina [44]. Com base no modelo da Figura 10 pode-se dizer que é mais energeticamente favorável para o átomo de $\mathrm{H}$ se ligar aos defeitos do que se difundir pelos sítios normais da rede cristalina. No entanto, no próprio trabalho de Lee e Lee [44] é sugerido que para alguns tipos de traps, como o TiC, dependendo da temperatura em que o material se encontra, o aprisionamento do $\mathrm{H}$ é energeticamente desfavorável - a $E_{\mathrm{s}}$ é maior do que a $E_{\mathrm{aD}}$. Existem outros modelos para explicar o comportamento energético do H, além deste proposto por Lee e Lee [44], como o de Oriani [45] e de Yang et al [46], que divergem nos valores estimados de energia de ativação e ligação dos traps em relação aos de sítios normais da rede cristalina. Uma discussão sobre as diferenças entre os três modelos mencionados pode ser encontrada no trabalho de HincapieLadino [47].

A técnica de análise térmica mencionada anteriormente, utilizada por Lee e Lee [44], consiste, basicamente, em aquecer a uma taxa constantea amostra, carregada previamente com hidrogênio, e medir o hidrogênio desprendido por cromatografia a gás. A medida do hidrogênio liberado também pode ser feita por espectrometria, como no caso da Técnica de Espectroscopia de Dessorção Térmica (Thermal Desorption Spectroscopy, TDS). Análises do teor de $\mathrm{H}$ são bastante difundidas e usadas para determinar $\mathrm{E}_{\mathrm{B}}$ e $\mathrm{E}_{\mathrm{aT}}$ em outros tipos de aço, como o AERMET 100 de Ultra Alta Resistência [48] e o ODS Eurofer [49].

A Figura 11, retirada do trabalho de Lee e Lee [44], contém um exemplo de curva de taxa de evolução de hidrogênio em função da temperatura.

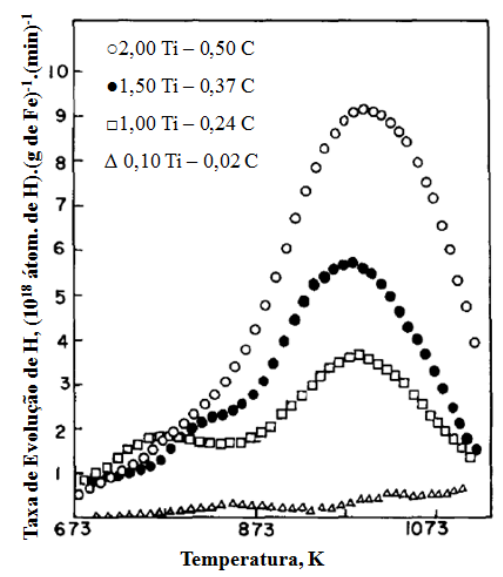

Figura 11. Resultados de análise de dessorção térmica para aços com diferentes teores de Ti e de C, mostrando os picos referentes à interface TiC-Fe. Modificado de [44]. 
O pico de evolução do $\mathrm{H}$, ou seja, o pico que representa a quantidade máxima de $\mathrm{H}$ que escapou do trap, ocorre em temperatura específica para cada tipo de sítio, indicando que cada trap tem uma energia de ativação característica. No exemplo da Figura 11 o trap é a interface TiC-Fe e observa-se que os átomos de H são liberados apenas em temperaturas em torno de $983 \mathrm{~K}$. Também é possível notar que existe uma relação entre a quantidade de $\mathrm{H}$ na estrutura do material e a quantidade de TiC presente - quanto maior esta última, mais $\mathrm{H}$ é aprisionado [44].

A Tabela 4 abaixo apresenta valores de $E_{B}$ e $E_{a T}$ retirados de diversos artigos da literatura para os principais tipos de traps dos materiais metálicos. Os artigos que forneceram os valores das energias são representados entre colchetes, ao lado de cada energia.

Tabela 4. Valores de $\mathrm{E}_{\mathrm{aT}}$ e $\mathrm{E}_{\mathrm{B}}$ para diferentes tipos de traps de hidrogênio em aços. As referências de cada valor são indicadas entre colchetes [].

\begin{tabular}{|c|c|c|}
\hline Tipo de trap & $\begin{array}{c}\text { Energia de ativação do trap, } \mathbf{E}_{\mathrm{aT}}, \\
\left(\mathrm{kJ}^{\left.\mathrm{m} . \mathrm{mol}^{-1}\right)}\right.\end{array}$ & Energia de ligaçãa, $E_{B},\left(k J \cdot m^{-1}\right)$ \\
\hline Contorno de grão (ferrita) & 16,30 [44]; 17,20 [50] & $9,60[50]$ \\
\hline Interface austenita-ferrita & - & $\sim 52,00[51]$ \\
\hline Interface martensita & - & $61,3-62,2[48]$ \\
\hline Interface de cementita & $18,35[44]$ & 10,85 [52]; 8,40-15,70 [53] \\
\hline Discordâncias & $26,04[44] ; 26,8[50]$ & $18,00-59,90[50,53] ; 25,60[54]$ \\
\hline $\begin{array}{l}\text { Microvazio em ferro } \\
\text { laminado a frio }\end{array}$ & $35,15[44]$ & $29,1[54]$ \\
\hline Interface $\mathrm{MnS}$-ferrita & $72,30[44]$ & $72,00[55]$ \\
\hline Interface $\mathrm{Al}_{2} \mathrm{O}_{3}$-ferrita & $78,96[44]$ & $79,00[55]$ \\
\hline $\begin{array}{c}\text { Interface } \mathrm{M}_{2} \mathrm{C} \text {-ferrita - } \\
\text { precipitado coerente }\end{array}$ & - & $11,40-11,60[53]$ \\
\hline Interface VC-ferrita & $33,00-35,00[56]$ & $\sim 28,00[56]$ \\
\hline $\begin{array}{l}\text { Interface TiC-ferrita - } \\
\text { precipitados incoerentes }\end{array}$ & $86,98[44]$ & $\sim 55,80[56]^{*} ; 46,00-116,00[55]$ \\
\hline $\begin{array}{l}\text { Interface } \mathrm{NbC} \text {-ferrita - } \\
\text { precipitados coerentes }\end{array}$ & $39,00-48,00[57]$ & - \\
\hline $\begin{array}{c}\text { Interface NbC-ferrita - } \\
\text { precipitados semicoerentes }\end{array}$ & - & $28,00-56,00[53]$ \\
\hline $\begin{array}{l}\text { Interface } \mathrm{NbC} \text {-ferrita - } \\
\text { precipitados incoerentes }\end{array}$ & $63,00-68,00[57]$ & - \\
\hline
\end{tabular}

* No artigo citado, a faixa de valores de energia de ligação é de precipitados semicoerentes de TiC. 
Como se pode observar pela Tabela 4, os valores de energia de ativação e de ligação de carbonetos dependem de sua coerência com a matriz. Quanto maior o grau de coerência, menores os valores de energia de ativação e de ligação.

Hincapie-Ladino [47] em sua tese de doutorado faz importantes observações a respeito dos valores de energia de ativação e de ligação dos traps: boa parte deles, inclusive de alguns mostrados pela Tabela 4, foi determinada há duas ou três décadas para aços com diferentes teores de $\mathrm{C}$ e de $\mathrm{S}$ dos usados atualmente e, por isso, é de interesse da comunidade científica que novas medidas dessas energias sejam feitas em novos aços [47].

Em um artigo de revisão, Bhadeshia [55] discute a classificação dos traps em reversíveis e irreversíveis de forma mais completa do que a apresentada pela norma ASTM G48-97 [40]. Para o autor, o termo irreversível implica que, em determinadas condições de serviço e supondo que as mesmas se mantenham constantes ao longo do período de utilização do aço, o H aprisionado não será capaz de retornar à rede cristalina e se unir aos átomos de $\mathrm{H}$ difusíveis. Ainda, de acordo com o autor, a classificação que se baseia apenas nos valores de energia de ligação é falha, pois não considera o tempo e o ambiente de trabalho do aço [55]. O autor explica que em um ensaio de dessorção térmica, o H liberado em baixas temperaturas é fracamente aprisionado, enquanto que o $\mathrm{H}$ aprisionado de modo irreversível será liberado apenas em temperaturas mais elevadas; contudo, as temperaturas dos picos dependem das taxas de aquecimento usadas que, por sua vez, dão ênfase à influência do tempo no processo de desaprisionamento de $\mathrm{H}$ [55]. Conhecer a temperatura de trabalho também é essencial para classificar os traps de modo mais adequado: um trap com energia de ligação de $100 \mathrm{~kJ} / \mathrm{mol}$, por exemplo, é considerado irreversível à temperatura ambiente, porém, se torna reversível quando a temperatura é suficientemente elevada [55].

Apesar das incertezas associadas aos valores de energia de ativação e de ligação apresentados pela Tabela 4 e encontrados em diversos artigos da literatura o seu conhecimento é essencial para entender o comportamento do $\mathrm{H}$ nos aços. Também é interessante determinar um valor limiar de energia de ligação, aproximado para cada temperatura de trabalho (ou faixa de temperatura de trabalho), acima do qual um trap pode ser considerado irreversível. Uma boa referência para se consultar este valor é o clássico artigo de Pressouyre GM, de 1979 [58]. Nele, o valor limiar a partir do qual o trap pode ser classificado

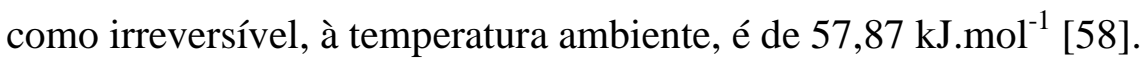


Os traps de $\mathrm{H}$ têm fundamental importância nos mecanismos de fragilização. Além dos tipos existentes, as suas distribuições pelo volume do material podem ser fatores decisivos para que ocorra perda de propriedades mecânicas, trincamento ou fratura [58].

As próximas seções discutem com mais detalhes alguns tipos de traps que possuem maior relevância para o presente trabalho.

\subsubsection{Inclusões}

As inclusões não metálicas, principalmente as de $\mathrm{MnS}$ que apresentam formato alongado, consistem em um dos mais perigosos tipos de sítio de aprisionamento de $\mathrm{H}$.

Os átomos de $\mathrm{H}$, supondo que estejam saturando completamente o volume do aço, vão se ancorar, preferencialmente, por toda extensão da interface inclusão/matriz, porém, as pontas das extremidades da inclusão consistem no grande problema. As pontas atuam como concentradores de tensão da matriz e, adicionalmente, criam microcavidades (ou microvazios) na interface inclusão/matriz, que atraem ainda mais os átomos de H [7, 27]. Dessa forma, as tensões na matriz ao redor das pontas da inclusão se tornam maiores, e passam a constituir sítios mais propensos para nucleação de trincas. É possível dizer, então, que na região em torno de uma inclusão pode haver uma combinação de fatores que promovem a fragilização do aço: a própria interface matriz/inclusão, as microcavidades derivadas deste tipo de interface e os campos de tensão na matriz ao redor das pontas da inclusão.

As microcavidades formadas nas interfaces de inclusões podem ser classificadas como traps dinâmicos, ou traps não saturáveis, uma vez que sua capacidade de aprisionamento é aumentada em função da entrada de $\mathrm{H}$ no metal e do aumento da pressão de gás $\mathrm{H}_{2}$ em seu interior [59]. Quando a pressão de $\mathrm{H}_{2}$ em um microvazio é suficientemente alta, um blister é formado.

A Figura 12, retirada do artigo de Huang F et. al. [37], mostra uma trinca iniciada em uma inclusão de $\mathrm{Al}_{2} \mathrm{O}_{3}$ com formato irregular. Estes autores estudaram três chapas de aços para tubos API X120, com altos teores de Mn (variando de 1,92 a 2,14\% em massa de Mn) e com microestruturas compostas, basicamente, por ripas de bainita e bainita globular, distribuídas simetricamente ao longo dos contornos de grão austeníticos, que estavam visíveis. Apesar de a inclusão apresentada ser de $\mathrm{Al}_{2} \mathrm{O}_{3}$, os autores comentam que os tipos de inclusões encontrados em seus aços eram, além deste mencionado, de MnS [37]. 


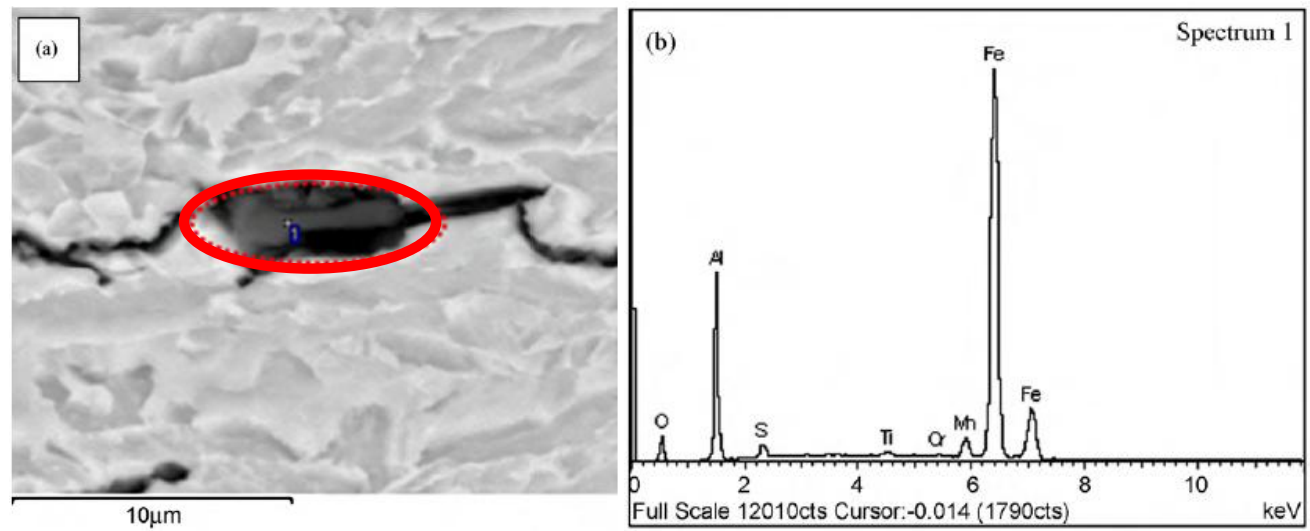

Figura 12. (a) Micrografia de elétrons retroespalhados que mostra trinca iniciada em inclusão. (b) Análise química composicional, obtida por EDS, da inclusão destacada em (a). Aumento usado não indicado pelos autores [37].

Segundo Lee e Lee [44], as temperaturas dos picos de $\mathrm{H}$ liberado de interfaces de inclusões de $\mathrm{MnS}$ e de $\mathrm{Al}_{2} \mathrm{O}_{3}$ são de, respectivamente, $495^{\circ} \mathrm{C}$ e $580{ }^{\circ} \mathrm{C}$ [44]; portanto, estes tipos de traps podem ser considerados irreversíveis a temperatura ambiente, na qual boa parte dos ensaios de permeabilidade ao $\mathrm{H}$ é realizada, e a $50{ }^{\circ} \mathrm{C}$ [29], temperatura de operação de oleodutos e gaseodutos.

\subsubsection{Segregação de elementos de liga e traps dela decorrentes: átomos}

\section{de soluto, bandeamento e cavidades de encolhimento}

Durante a solidificação de um aço ocorre a partição de elementos químicos entre o líquido e o cristal em crescimento, resultando na distribuição não uniforme dos elementos de liga pelo volume do produto solidificado. Essa partição, ou segregação, pode ser observada macroscopicamente como uma linha central em produtos fundidos continuamente, ou nos topos e faces inferiores, além das linhas centrais, de lingotes [60].

Microscopicamente, a segregação se dá entre as dendritas de uma seção solidificada e, durante processos de laminação a quente, é alinhada longitudinalmente, formando bandas. As bandas são mais evidentes nos aços quando compostas por diferentes microconstituintes (por exemplo, bandas de ferrita e de perlita), estando presentes em maior ou menor grau em todos os tipos de aços laminados [60].

As regiões de segregação de elementos de liga, em especial as centrais, nas quais a segregação é mais pronunciada, são altamente prejudiciais para a boa resistência à fragilização por H. Primeiro porque os próprios átomos substitucionais ou intersticiais segregados são sítios de aprisionamento de H. Segundo, porque a segregação de elementos de 
liga dá origem ao bandeamento da microestrutura, a microconstituintes de dureza mais elevada e a cavidades (ou microcavidades) de encolhimento, também conhecidas como rechuoes [27] (mesma natureza das microcavidades formadas próximas às interfaces inclusão/matriz).

$\mathrm{O}$ aprisionamento de $\mathrm{H}$ por átomos substitucionais ou intersticiais é relatado por vários autores [55, 61, 62, 63]. Segundo Bhadeshia [55], átomos individuais de elementos químicos em solução são capazes de atrair apenas alguns poucos átomos de $\mathrm{H}$ e suas energias de ligação são determinadas, na maior parte das vezes, por métodos computacionais e de relaxação magnética - o uso de espectroscopia de dessorção térmica, nesse caso, não é o mais adequado porque os solutos provocam alterações na microestrutura e, consequentemente, inserem outros tipos de traps na análise [55]. De acordo com um levantamento bibliográfico feito por Bhadeshia [55], os valores de energia de ligação entre o H e alguns átomos de soluto, obtidos por cálculos de primeiros princípios, cálculos elásticos/eletrônicos e relaxação

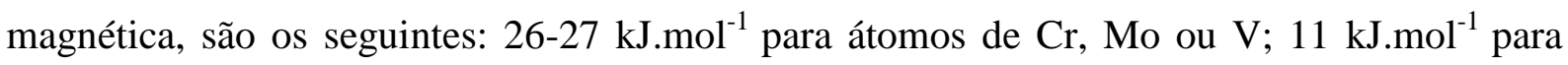
$\mathrm{Mn} ; 3 \mathrm{~kJ} . \mathrm{mol}^{-1}$ para o C e $13 \mathrm{~kJ} . \mathrm{mol}^{-1}$ para o N [55]. Alguns destes valores informados por [55] contradizem os resultados de Counts et al [63]. Counts et al [63], através de cálculos de DFT (Density Functional Theory, Teoria de Densidade Funcional) encontraram que a energia de ligação máxima do $\mathrm{H}$ com $\mathrm{Cr}$, Mn, Co e Mo é de $0 \mathrm{eV}$ (zero), indicando que estes átomos não interagem com o H [63]. De qualquer modo, independente do valor da energia de ligação do soluto com o $\mathrm{H}$, a região segregada irá concentrar mais átomos de $\mathrm{H}$ do que as regiões sem segregação, o que pode levar à falha em serviço.

Elementos como o C, Mn, S, P e O, quando segregados, influenciam a cinética de transformação dos aços e, assim, dão origem a microconstituintes diferentes dos encontrados em outras regiões do material [7]. Assim como no caso dos solutos, os tipos diferentes de microconstituintes distribuídos de maneira heterogênea pelo volume irão fragilizar o material - o H irá se ligar aos pontos que já são concentradores de tensão e irá torná-los sítios mais propícios para nucleação de trincas.

Outro desdobramento da segregação de elementos de liga é a formação de bandeamento, que pode levar à anisotropia do coeficiente de difusão efetiva do H pelo aço [64]. Dependendo da orientação da seção de entrada de H no aço, a difusão do H pode ser dificultada: as bandas de microestrutura podem atuar como obstáculos à movimentação do $\mathrm{H}$ [64]. 
Por último, porém não menos importante, a segregação é responsável pela formação de poros (cavidades) de encolhimento na linha central dos aços durante o lingotamento contínuo. Quando H em excesso se acumula nestas cavidades, a sua aniquilação durante o processamento a quente é dificultada; os átomos de $\mathrm{H}$ se recombinam formando moléculas de $\mathrm{H}_{2}$ e, quando a pressão é alta o bastante, ocorre o trincamento na linha central [7,27]. Além de serem consideradas traps não saturáveis [59], as cavidades podem ser classificadas como traps irreversíveis. Como o $\mathrm{H}$ nas cavidades tende a se recombinar e formar moléculas de $\mathrm{H}_{2}$, estas últimas teriam de se dissociar para, depois, o $\mathrm{H}$ abandonar o trap e retornar à rede cristalina [55].

A Figura 13, retirada de [27], mostra um exemplo de trinca tipicamente encontrada em linhas centrais de lingotes/chapas.

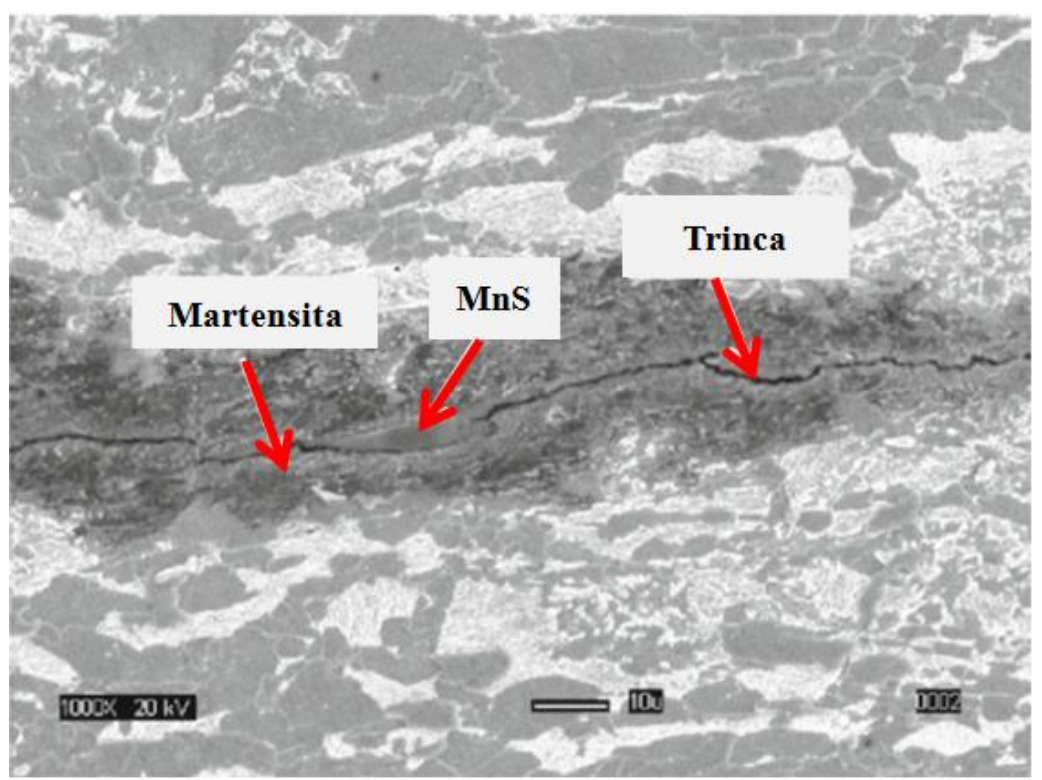

Figura 13. Micrografia que mostra o trincamento induzido por hidrogênio na linha central de uma chapa de aço X70. Aumento: 1000 x. Modificado de [27].

De acordo com os autores [27] a trinca apresentada pela Figura 13 teve início na interface martensita/MnS e se propagou ao longo da região segregada.

\subsubsection{Precipitados de microadições de elementos de liga}

As microadições de elementos de liga como Nb, V e Ti em aços HSLA têm a principal função de formar precipitados finos, como carbonetos ou carbonitretos, durante o processo de laminação controlada dos aços. Estes precipitados têm o papel de ancorar os contornos de grão de austenita quando é feito o reaquecimento do aço e, assim, mantê-los com pequenas 
dimensões durante a etapa de recristalização. Dessa forma, é obtido o elevado grau de refinamento de grão ferrítico característico deste tipo de processamento - e que garante que os aços tenham boa resistência mecânica e ductilidade. O processo é melhor explicado no Anexo A, ao final do presente trabalho. Essa pode ser considerada como a principal maneira de precipitados serem inseridos na microestrutura de aços HSLA. Outro meio para obtenção de precipitados na microestrutura é o tratamento de têmpera e revenimento, como mostrado pela Figura 5 e feito por Fallahmohamadi et.al. [30]. Tendo isso em mente, espera-se que aços HSLA laminados de forma controlada apresentem precipitados em sua microestrutura, mesmo que a sua caracterização só possa ser feita com técnicas mais avançadas, como Microscopia Eletrônica de Transmissão.

A Tabela 4 apresenta energias de ligação e de ativaçãode alguns tipos de precipitados; também se observa que o valor de energia de ligação depende do grau de coerência dos precipitados com a matriz: quanto mais incoerente for o precipitado, maior o valor da energia de ligação com o H. De um modo geral, os precipitados incoerentes são classificados como traps irreversíveis de $\mathrm{H}$, devido a sua alta energia de ligação. No caso de precipitados coerentes ou semicoerentes com a matriz, essa classificação é discutível - segundo Findley et. al. [53] e Liu et. al. [65] precipitados coerentes e semicoerentes são traps reversíveis.

Os traps reversíveis são considerados mais danosos para o aço do que os traps irreversíveis (traps irreversíveis não concentradores de tensão) $[53,55,56]$. O H aprisionado por um trap reversível pode retornar com relativa facilidade à rede cristalina e interagir com outros átomos de H difusível e defeitos da microestrutura. Já o H ligado a um trap irreversível não consegue retornar à rede e, uma vez saturado, o trap irreversível se torna inativo - não se liga mais a átomos de $\mathrm{H}$ e nem influencia na difusão dos mesmos.

O modo como os traps irreversíveis estão distribuídos pelo volume do aço pode melhorar consideravelmente a resistência aos danos pelo H. O uso de nanoprecipitados, como carbonetos, nitretos e carbonitretos, distribuídos de maneira homogênea pela microestrutura, tem sido comentado e estudado por diversos autores [36, 48, 53, 55, 56, 57, 66]. As nanopartículas são vistas como uma solução para a melhora da resistência à fragilização por $H$ em aços com graus API mais elevados (martensíticos, normalmente, ou com outras estrutruras aciculares). Os resultados mostram que os nanoprecipitados, além de promoverem o aumento da resistência mecânica, melhoram consideravelmente a resistência aos danos por H. Com a distribuição homogênea dos traps e, consequentemente, do $\mathrm{H}$ imobilizado por eles, não são 
criadas regiões concentradoras de tensão e, assim, a nucleação de microtrincas e trincas é prevenida [36].

\subsubsection{Interface cementita/ferrita (perlita) e contornos de grão de}

\section{ferrita}

Como se pode observar pela Tabela 4 , tanto as interfaces de cementita/ferrita como os contornos de grão ferríticos possuem baixos valores de energia de ativação e de ligação - as energias para os dois tipos de traps podem ser consideradas iguais. Assim, estes tipos de interface e de contornos podem ser classificados como traps reversíveis.

Hong e Lee [52] estudaram a influência da quantidade de interface ferrita/cementita na permeabilidade e difusividade do $\mathrm{H}$ em aços carbono. Os aços foram produzidos especificamente para isso, a partir da fusão de ferro eletrolítico e grafita em um forno de indução. Para que fossem avaliados somente os efeitos da quantidade de interfaces ferrita/cementita, os lingotes obtidos apresentavam a mesma composição química, com exceção dos teores de C, que eram de 0,12 e 0,49\% em massa, e também passaram pelos mesmos tratamentos térmicos de normalização. Deste modo os autores puderam assumir que o número e natureza dos demais tipos de traps existentes fossem os mesmos nos dois aços. Os ensaios de permeabilidade mostraram que a difusividade e a permeabilidade ao $\mathrm{H}$ diminuíram com o aumento da quantidade de interface ferrita/cementita - aumento da fração volumétrica de perlita [52]. Também foram realizados ensaios de dessorção térmica e, através deles, os autores determinaram que a energia de ligação do $\mathrm{H}$ com este tipo de interface era baixa, de $10,85 \mathrm{~kJ} \mathrm{~mol}^{-1}$. Os autores estimaram os níveis de energia do $\mathrm{H}$ nas proximidades de uma interface ferrita/cementita e montaram uma curva similar à apresentada pela Figura 10, e que é reproduzida abaixo pela Figura 14 [52]. 


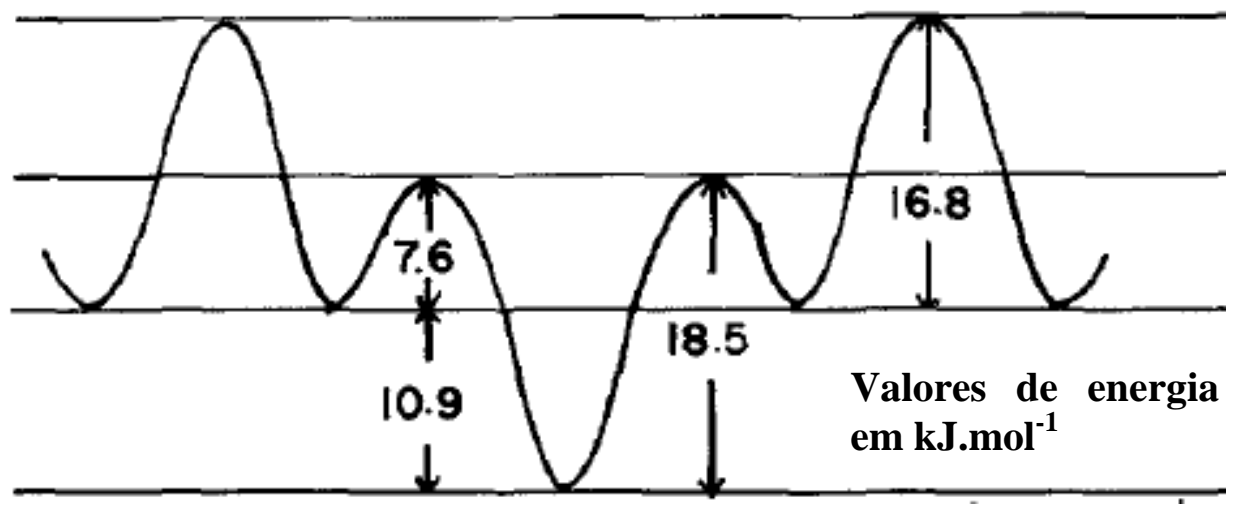

Figura 14. Níveis de energia apresentados pelo átomo de $\mathrm{H}$ em torno de uma interface ferrita/cementita; valores de energia em kJ.mol ${ }^{-1}$. Modificado de [52].

Os valores da Figura 14 mostram que a energia $E_{s}$, requerida para o $\mathrm{H}$ migrar de um sítio normal da rede para uma interface ferrita/cementita, é mais baixa $\left(7,6 \mathrm{~kJ} \mathrm{~mol}^{-1}\right)$ do que a energia de ativação $\mathrm{E}_{\mathrm{aD}}\left(16,8 \mathrm{~kJ} \cdot \mathrm{mol}^{-1}\right)$, necessária para que os átomos de $\mathrm{H}$ se difundam pelos sítios intersticiais da rede cristalina. Em outras palavras, é mais favorável energeticamente para o $\mathrm{H}$ migrar para o trap do que permanecer na rede cristalina. Ainda, pode-se inferir que com esse valor baixo de $\mathrm{E}_{\mathrm{s}} \mathrm{o} \mathrm{H}$ pode ser aprisionado pela interface ferrita/cementita à temperatura ambiente. Através da Figura 14 também é possível verificar que a interface ferrita/cementita tem baixa capacidade de aprisionamento de $\mathrm{H}$ : apesar de ser um trap e de ser mais favorável para o $\mathrm{H}$ migrar para ela, a sua energia de ligação com o $\mathrm{H}$ e a energia de ativação para escape do $\mathrm{H}$ são baixas, de 10,9 $\mathrm{kJ}^{\mathrm{mol}}{ }^{-1}$ (arredondamento dos 10,85 kJ.mol ${ }^{-1}$ informados) e de 18,5 $\mathrm{kJ} \mathrm{mol}^{-1}$, respectivamente [52]. Outros autores, como Wei e Tsuzaki [56], que escreveram excelente capítulo sobre o aprisionamento de $\mathrm{H}$ em aços martensíticos, no livro "Gaseous Hydrogen Embrittlement of Materials in Energy Technologies", também informam que a cementita não demonstra ter capacidade significativa de aprisionamento de $\mathrm{H}$ em aços martensíticos com teores baixos e médios de carbono, devido às fracas ligações formadas com o $\mathrm{H}[56]$.

Choo e Lee [50] determinaram as energias de ligação e de ativação de contornos de grão ferríticos, discordâncias e de microvazios no ferro puro. Para estudar os contornos de grão, uma série de quatro amostras de ferro puro foi submetida a um mesmo grau de deformação a frio e a diferentes tempos de recozimento, de modo que a densidade de discordâncias e microvazios fossem mantidas constantes e o tamanho de grão ferrítico fosse alterado. Após caracterização microestrutural, os ensaios de dessorção térmica foram 
realizados. Os resultados de dessorção térmica e de caracterização microestrutural são apresentados pela Figura 15 [50].
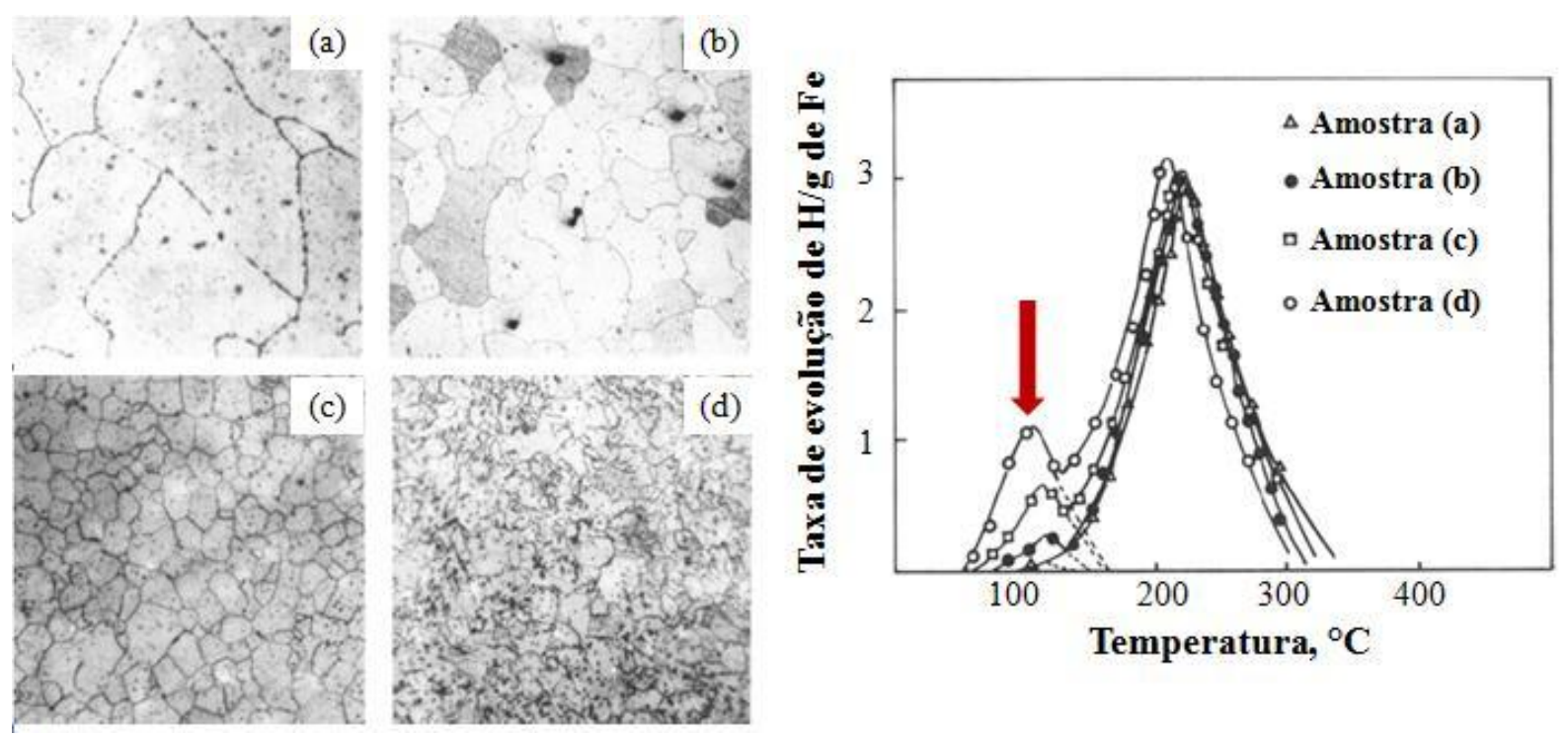

Figura 15. À esquerda: micrografias óticas de amostras de ferrita pura com diferentes tamanhos de grão ASTM (a) ASTM n ${ }^{\circ}$, (b) $\operatorname{ASTM~n}^{\circ}$ 4, (c) $\operatorname{ASTM~n}^{\circ} 7$ e (d) ASTM n ${ }^{\circ}$ 9. Aumento usado para todas as micrografias: 65 x. À direita: resultados de dessorção térmica para as mesmas amostras. O pico associado aos contornos de ferrita é indicado pela seta vermelha. Modificado de [50].

Na Figura 15 podem-se observar dois picos de dessorção diferentes: um a $112{ }^{\circ} \mathrm{C} \mathrm{e}$ outro a $215{ }^{\circ} \mathrm{C}$. Os picos a $215{ }^{\circ} \mathrm{C}$ de todas as amostras apresentam alturas iguais; já a altura do primeiro pico aumentou em função do tamanho de grão de cada amostra. Conforme o tamanho de grão de ferrita diminuía, o pico a $112{ }^{\circ} \mathrm{C}$ aparecia mais alto, ou seja, conforme a quantidade de contornos de grão de ferrita aumentava, maior teor de $\mathrm{H}$ entrava no material. Este experimento permitiu identificar o pico característico de contornos de grão de ferrita e a determinar a energia de ligação com o $\mathrm{H}$ e a energia de ativação do trap, de 9,6 e de 17,2 $\mathrm{kJ} . \mathrm{mol}^{-1}$ respectivamente [50]. $\mathrm{O}$ pico a $215^{\circ} \mathrm{C}$ foi associado às discordâncias.

O experimento realizado por Choo e Lee [50], sozinho, não permite o entendimento do papel dos contornos de grão na difusão dos átomos de H. Alguns autores comentam sobre a possibilidade dos contornos de grão atuarem como caminhos mais favoráveis para a difusão do $\mathrm{H}$ pelo material, ou como obstáculos ao movimento do $\mathrm{H}$, dependendo de seu alinhamento $[32,64,67]$. Contornos de grão em regiões onde se encontram alinhados podem ser caminhos preferenciais para os átomos de $\mathrm{H}$ e pontos onde contornos se unem podem dificultar a movimentação dos átomos de $\mathrm{H}[32,64,67]$. 
A influência de alguns traps na difusividade do $\mathrm{H}$, como os contornos de grão e o bandeamento microestrutural, é um dos objetos de estudo do presente trabalho. Assim, estes tópicos serão discutidos mais detalhadamente na seção 3.7, junto da influência da textura; antes disso é descrito e discutido o ensaio de permeabilidade ao $\mathrm{H}$, técnica que permite calcular o coeficiente de difusão do $\mathrm{H}$ no aço, entre outros parâmetros.

\subsection{Ensaio de permeabilidade ao hidrogênio}

Uma importante ferramenta usada para entender os mecanismos envolvidos na fragilização por $\mathrm{H}$ e, assim, para avaliar a suscetibilidade de aços aos danos por $\mathrm{H}$, é a técnica de permeabilidade ao H. Desenvolvida por Devanathan e Stachurski [68], a técnica consiste, basicamente, em promover a entrada de átomos de $\mathrm{H}$ em uma amostra metálica, que irão atravessá-la, e medir o fluxo de $\mathrm{H}$ que alcança a face de saída da amostra. Para isso é usado um sistema com duas células eletroquímicas, que devem ser separadas somente pela amostra de interesse. A Figura 16, modificada de [68], contém uma esquematização do sistema básico de células e amostra normalmente usado.

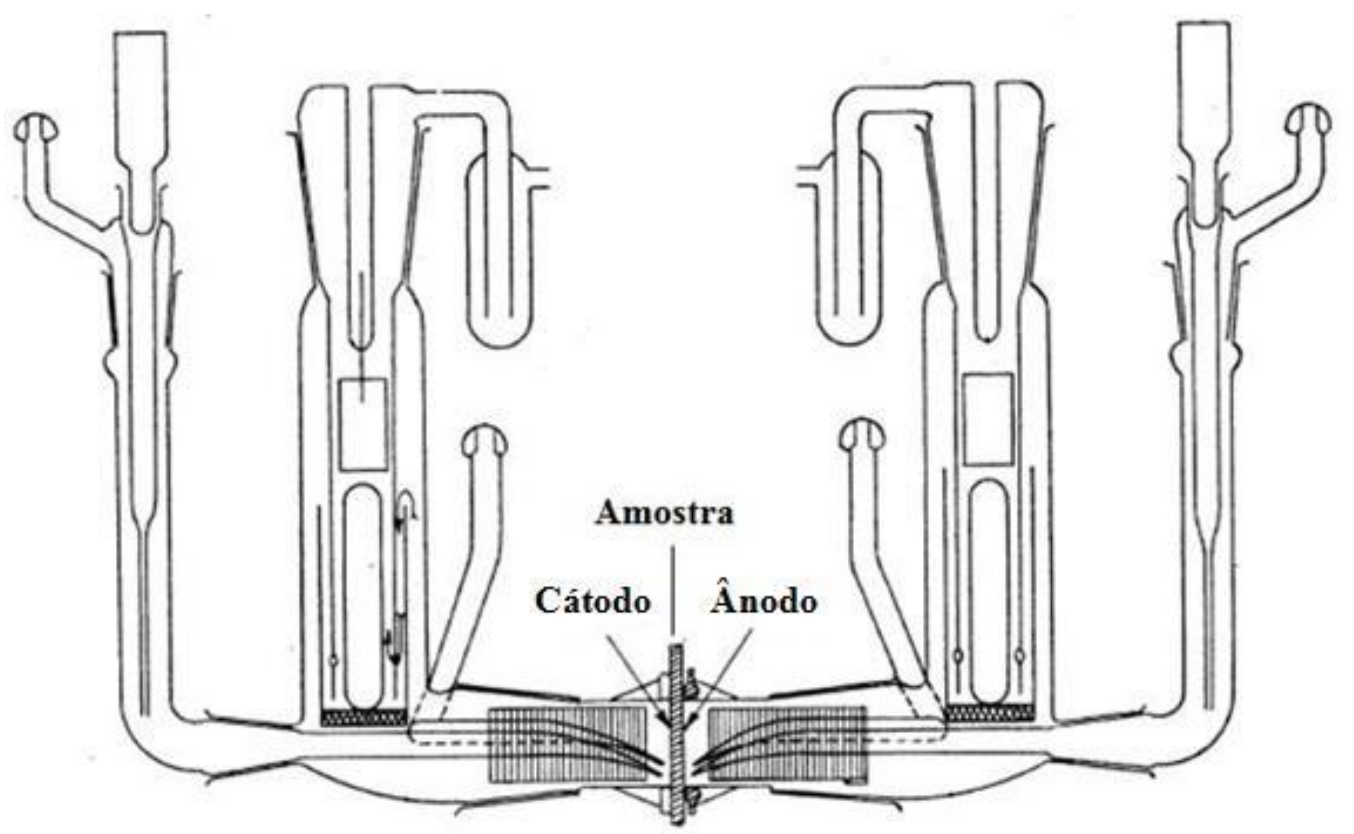

Figura 16. Esquematização do sistema básico de células eletroquímicas usado no ensaio de permeabilidade ao H. Modificado de [68].

Na Figura 16, os átomos de H são gerados no cátodo (célula de redução, ou célula de geração de H) e, após permear a amostra, são detectados no ânodo (célula de oxidação). Para 
que ocorra difusão, é necessário que exista diferença de concentração de $\mathrm{H}$ entre as duas células e este requisito pode ser facilmente satisfeito de diversas maneiras. Originalmente, Devanathan e Stachurski [68] utilizaram dois potenciostatos, um conectado em cada célula eletroquímica, para polarizar anódica e catodicamente cada face da amostra, e o eletrólito usado nas duas células foi uma solução de $0,1 \mathrm{M}$ de $\mathrm{NaOH}$. Nesse caso, através de aplicação de potencial (ou corrente), a polarização catódica foi responsável pela ocorrência da reação de formação de $\mathrm{H}$ atômico (Reação 5), e, conseqüentemente, pela concentração $\mathrm{C}_{\mathrm{o}}$ de hidrogênio na face da amostra voltada para o cátodo - a Reação 5 ocorre na superfície da amostra. O lado anódico do sistema de células tem concentração de $\mathrm{H}$ igual a zero e, dessa forma, é estabelecida a diferença de concentrações de $\mathrm{H}$, que é a força motriz para a difusão [68].

Existem outros tipos de arranjos para este ensaio, como utilização de potenciostato na célula de oxidação e de solução com veneno catódico na célula de redução, sem o segundo potenciostato; uso de dois potencistatos com injeção de gases [32, 38, 41, 64]. No caso do carregamento feito sem o uso de potenciostato, é essencial que esteja presente o veneno catódico - por exemplo, com a injeção constante de $\mathrm{H}_{2} \mathrm{~S}$, o que simula de forma mais realista o ambiente a que os aços são submetidos durante o serviço. Na ausência de potenciostato do lado catódico do sistema, o meio de trabalho é o responsável pela corrosão do aço e ocorrência da Reação 5 de formação de H, e o veneno catódico tem o papel de intensificar a entrada de $\mathrm{H}$ atômico na superfície da amostra.

$\mathrm{Na}$ célula de oxidação do $\mathrm{H}$, localizada na parte anódica do sistema, se faz crucial a utilização do potenciostato, que irá aplicar potencial anódico ao sistema e irá orientar a saída dos átomos de $\mathrm{H}$ pela amostra, que são oxidados a $\mathrm{H}^{+}$quando entram em contato com o meio desta célula. $\mathrm{O}$ potencial anódico aplicado faz com que os átomos de $\mathrm{H}$ se distribuam pelo volume de material delimitado pelas áreas expostas aos eletrólitos, e não pela amostra inteira. A Figura 17 ilustra o volume da amostra que é saturado com H, após aplicação de potencial ou corrente anódica. 


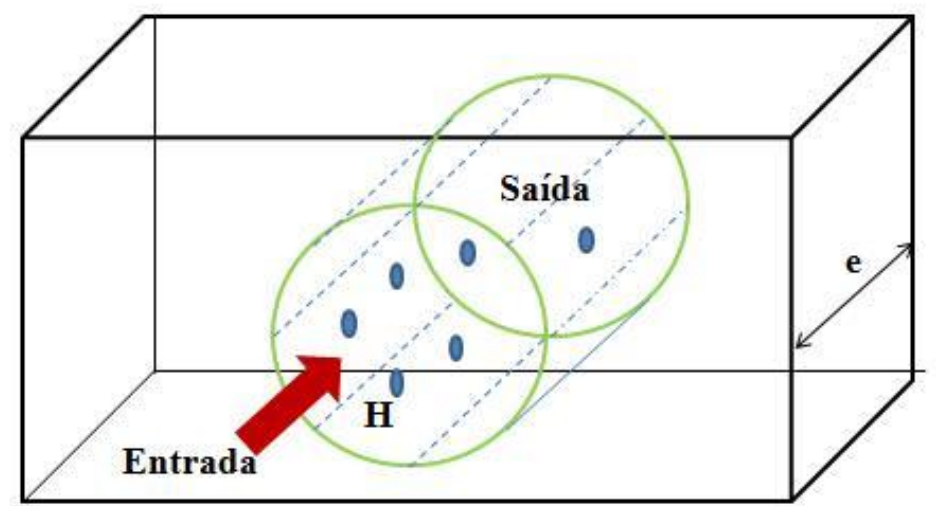

Figura 17. Ilustração do volume de amostra que é saturado e percorrido por $\mathrm{H}$ durante o ensaio de permeabilidade, com aplicação de potencial anódico.

Na Figura 17, a dimensão indicada por "e" é a espessura da amostra, a seta vermelha indica a direção e o sentido do fluxo de $\mathrm{H}$, devido à aplicação de potencial anódico e os pequenos círculos azuis representam os átomos de H. É importante explicar que a representação de $\mathrm{H}$ atômico no interior do material é feita de modo simplificado; o $\mathrm{H}$ dissolvido, na verdade, interage com a estrutura metálica como se fosse um próton que cedeu seu elétron à nuvem eletrônica metálica [69].

Ao final desta seção, a Tabela 5 apresenta alguns tipos de eletrólitos e parâmetros eletroquímicos, como potencial e densidade de corrente, usados em ensaios de permeabilidade ao $\mathrm{H}$ por diversos autores da literatura. Para garantir que apenas as reações envolvendo entrada e permeabilidade de $\mathrm{H}$ ocorram, é importante que os eletrólitos e células sejam desaerados antes do início do ensaio [40], bem como que a face de saída de $\mathrm{H}$ da amostra seja recoberta com algum metal protetor, como paládio ou níquel [40, 70]. Todavia, há na literatura alguns trabalhos que utilizaram meios aerados, o que levou à obtenção de resultados duvidosos, já que outras reações eletroquímicas aconteceram em paralelo. Esta condição aerada é mostrada pela Tabela 5.

Os ensaios de permeabilidade de hidrogênio fornecem curvas de corrente (A) - que podem ser transformadas em densidade de corrente $\left(\mathrm{A} \cdot \mathrm{cm}^{-2}\right)$ - em função do tempo (s). A Figura 18, retirada do trabalho clássico de Devanathan e Stachurski [68], apresenta uma curva ideal, com a densidade de corrente convertida para $\mu \mathrm{A} . \mathrm{cm}^{-2}$, pois, normalmente, os valores observados das correntes medidas são dessa ordem. 


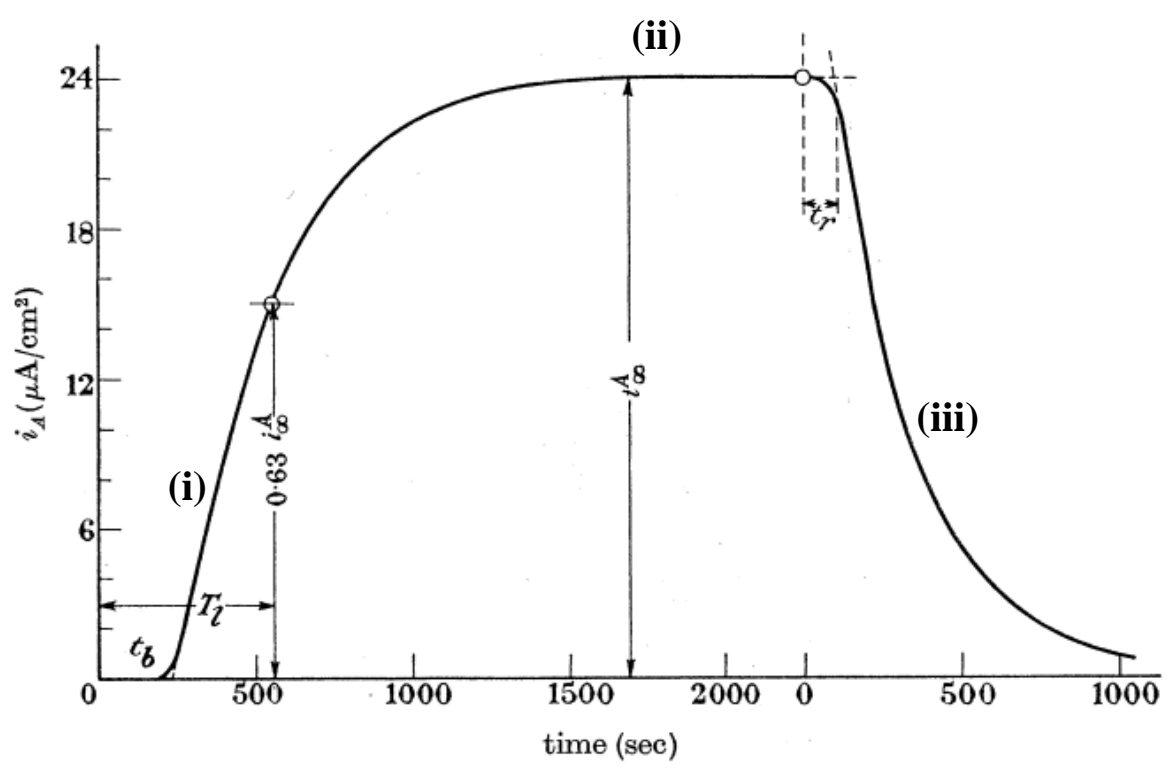

Figura 18. Desenho de uma curva ideal resultante de um ensaio de permeabilidade ao hidrogênio. Em (i) região do transiente, na qual a densidade de corrente $\left(\mathrm{i}_{\mathrm{A}}\right)$ aumenta com o tempo, em (ii) a região do estado estacionário, onde $\mathrm{i}_{\mathrm{A}}$ é constante ao longo do tempo e (iii) região de decaimento, em que $\mathrm{i}_{\mathrm{A}}$ diminui com o tempo. Retirada de [68].

Na curva da Figura 18 podem ser observadas três regiões distintas: (i) transiente, com $i_{A}$ aumentando em função do tempo, (ii) estado estacionário, em que $i_{A}$ torna-se constante ao longo do tempo e passa a ser chamada de $i_{A \infty}$ e (iii) região de decaimento, em que $i_{A}$ diminui com o tempo, quando é suspendida a geração de hidrogênio. Em (i) os átomos de hidrogênio penetram a face da amostra voltada para a célula redutora (geração de hidrogênio), atravessam o material e atingem a face da amostra voltada para a célula de oxidação, na qual são detectados. Quando a quantidade de átomos de hidrogênio que entram na amostra se torna igual à quantidade de átomos que deixam a amostra, se tem o estado estacionário, que corresponde à parte (ii) da curva. Por fim, na região (iii) de decaimento, a fonte geradora de átomos de $\mathrm{H}$ é interrompida (por exemplo, $\mathrm{H}_{2} \mathrm{~S}$ deixa de ser injetado na célula de geração), ou seja, cessa a entrada de $\mathrm{H}$ na amostra, e os átomos que estavam aprisionados na rede e em sítios reversíveis, principalmente, começam a escapar do interior do material.

A corrente eletroquímica medida pelo potenciostato, que forma a curva de $i_{A} x t$, tem origem na oxidação dos átomos de hidrogênio que, ao serem expostos à célula de oxidação, quando atravessam a amostra, se oxidam formando íons $\mathrm{H}^{+}$e elétrons. A Reação 6 mostra o fenômeno eletroquímico descrito:

$$
H \rightarrow H^{+}+e^{-}
$$


A partir das curvas de permeabilidade ao $\mathrm{H}$, é possível calcular uma série de parâmetros importantes para a compreensão dos mecanismos de fragilização e do comportamento do H no interior das estruturas metálicas. São eles:

- $\quad D_{\text {eff }}\left(\mathrm{cm}^{2} . \mathrm{s}^{-1}\right)$ : o coeficiente de difusão efetiva do hidrogênio no aço, ou seja, que considera a presença de traps reversíveis e irreversíveis na estrutura do material;

- $\quad \mathrm{C}_{0}\left(\mathrm{~mol} . \mathrm{cm}^{-3}\right)$ : concentração de hidrogênio atômico na sub-superfície da face de carregamento da amostra;

- $\quad \mathrm{N}_{\mathrm{t}}\left(\mathrm{cm}^{-3}\right)$ : número de sítios de aprisionamento de $\mathrm{H}$ por unidade de volume.

Para o cálculo destes parâmetros são usadas informações fornecidas pela curva de permeabilidade, que aparecem em destaque na Figura 18, e uma série de equações, apresentadas a seguir.

O coeficiente de difusão efetiva do hidrogênio pode ser calculado de duas maneiras diferentes: pelos métodos do time-lag e do time-breakthrough. Na Figura 18, o time-lag é identificado por $\mathrm{T}_{1}$, porém, será chamado de $\mathrm{t}_{\mathrm{lag}}$ no presente texto; este corresponde ao tempo em que $i_{\mathrm{A}}=0,63 i_{A \infty}$. Já o time-breakthrough, identificado na Figura 18 por $\mathrm{t}_{\mathrm{b}}$, equivale ao tempo decorrido para que os primeiros átomos de hidrogênio atravessem a amostra. Sua determinação gráfica se dá pela extrapolação da região reta do transiente. A Equação 1 apresenta a fórmula para cálculo de $\mathrm{D}_{\text {eff }}$ pelo método do time-lag; a Equação 2 mostra como se calcula $\mathrm{D}_{\text {eff }}$ pelo método do time-breakthrough $[32,40,58,68]$.

$$
D_{e f f}=\frac{e^{2}}{6 t_{l a g}}
$$

Onde: $\mathrm{e}=$ espessura do material, em $\mathrm{cm} ; \mathrm{t}_{\text {lag }}=$ tempo em que $\mathrm{i}_{\mathrm{A}}=0,63 i_{A \infty}$.

$$
D_{e f f}=\frac{e^{2}}{15,3 t_{b}}
$$

Para o cálculo de $\mathrm{C}_{0}$ é usada a Equação 3, retirada de [40]:

$$
C_{0}=\frac{J_{\infty} e}{D_{e f f}}
$$


Onde: $J_{\infty}=$ fluxo de hidrogênio atômico no estado estacionário.

A corrente pode ser transformada em fluxo atômico de hidrogênio através da Equação 4 [40]:

$$
J=\frac{I}{A F}
$$

Onde: $\mathrm{J}=$ fluxo de hidrogênio atômico, em mol.s $\mathrm{s}^{-1} \cdot \mathrm{cm}^{-2} ; \mathrm{I} / \mathrm{A}=\mathrm{i}_{\mathrm{A}}=$ densidade de corrente (corrente dividida pela área) e F = constante de Faraday, 9,6485 x 10 $\mathrm{C}^{4} \mathrm{~mol}^{-1}$.

Por fim, o número de traps por unidade de volume, $\mathrm{N}_{\mathrm{t}}$ pode ser calculado pela Equação 5 [45, 58]:

$$
N_{T}=\frac{C_{0}}{3}\left(\frac{D_{l}}{D_{e f f}}-1\right)
$$

Onde: $\mathrm{D}_{1}=$ coeficiente de difusão de rede do $\mathrm{H}$, em $\mathrm{cm}^{2} \cdot \mathrm{s}^{-1}$ e $\mathrm{C}_{0}=$ concentração de átomos de $\mathrm{H}$ no metal na unidade número de átomos. $\mathrm{cm}^{-3}$.

Ao se apresentar os resultados na forma de curvas de permeabilidade de $\mathrm{H}$, é comum normalizar os dados. Primeiro, a densidade de corrente é transformada em fluxo atômico, pela Equação 4. Depois, os valores de fluxo são apresentados em relação ao fluxo no estado estacionário (de valor teoricamente constante), ou seja, na forma $J / J_{\infty}$, sendo adimensionais. Para remover a influência da espessura da amostra nos resultados, o tempo também é normalizado (T), de acordo com a Equação 6, e passa a ter a unidade de $\mathrm{s.cm}^{-2}$ [40]:

$$
T=\frac{t}{e^{2}}
$$

Para maiores informações sobre a origem e dedução das Equações 1-6, pode-se consultar a tese de doutorado de Hincapie-Ladino [47], que explica de maneira clara e objetiva todo o desenvolvimento matemático por trás da técnica de permeabilidade.

A Tabela 5 mostra diferentes condições de ensaio (eletrólito, potencial, densidade de corrente, injeção de gases) usadas por autores da literatura, junto de valores de $\mathrm{D}_{\text {eff }}$ calculados pelo método do time-lag. 
Tabela 5. Condições de ensaio de permeabilidade ao $\mathrm{H}$ e os valores do coeficiente de difusão efetiva do $\mathrm{H}\left(\mathrm{D}_{\text {eff }}\right)$ para diferentes aços e microestruturas.

\begin{tabular}{|c|c|c|c|c|}
\hline Ref. & Aço & Microestrutura & Condições de ensaio & $\begin{array}{c}D_{\text {eff }} \\
\left(\mathrm{cm}^{2} \cdot \mathrm{s}^{-1}\right)\end{array}$ \\
\hline [71] & $\begin{array}{l}\text { Médio C, } \\
\text { temperado e } \\
\text { revenido }\end{array}$ & $\begin{array}{c}\text { martensita }+ \\
\text { ilhas de austenita } \\
\text { retida }\end{array}$ & $\begin{array}{l}\text { Catódico: } \mathrm{i}=10 \mathrm{~mA} \cdot \mathrm{cm}^{-2} \\
0,1 \mathrm{M} \mathrm{NaOH}+1 \mathrm{~g} \cdot \mathrm{L}^{-1} \\
\mathrm{Na}_{2} \mathrm{HAsO}_{4} \cdot 7 \mathrm{H}_{2} \mathrm{O} \\
\text { Anódico: } \mathrm{E}=+100 \mathrm{mV} / \mathrm{SCE} ; 0,2 \\
\mathrm{M} \mathrm{NaOH} . \\
\text { Não mencionado se o meio foi } \\
\text { desaerado. }\end{array}$ & $1,5 \times 10^{-7}$ \\
\hline [72] & HSLA & $\begin{array}{c}\text { ferrita quase- } \\
\text { poligonal }+ \\
\text { ferrita acicular }+ \\
\text { MA }\end{array}$ & $\begin{array}{l}\text { Catódico: } \mathrm{i}=40 \mathrm{~mA} \cdot \mathrm{cm}^{-2} ; 0,5 \mathrm{M} \\
\mathrm{H}_{2} \mathrm{SO}_{4}+0,2 \mathrm{~g} \cdot \mathrm{L}^{-1} \mathrm{As}_{2} \mathrm{O}_{3} \\
\text { Anódico: } \mathrm{E}=+300 \mathrm{mV} / \mathrm{Ag}- \\
\mathrm{AgCl} ; 0,1 \mathrm{M} \mathrm{NaOH} \\
\text { Meio desaerado (injeção de } \mathrm{N}_{2} \text { ) }\end{array}$ & $3,29 \times 10^{-6}$ \\
\hline [73] & $\begin{array}{l}\text { HSLA API } \\
\text { X65 }\end{array}$ & ferrita + perlita & $\begin{array}{l}\text { Catódico: } \mathrm{E}=-1100 \mathrm{mV} / \mathrm{SCE} \text {; } \\
0,42 \mathrm{M} \mathrm{NaCl}, \mathrm{pH}=8,22 \\
\text { Anódico: } 0,1 \mathrm{M} \mathrm{NaOH} \text {; foi usada } \\
\text { densidade de corrente, porém o } \\
\text { valor não foi informado. } \\
\text { Meio desaerado (injeção de } \mathrm{N}_{2} \text { ) }\end{array}$ & $2,35 \times 10^{-6}$ \\
\hline [74] & $\begin{array}{l}\text { HSLA API } \\
\text { X80 }\end{array}$ & $\begin{array}{l}\text { ferrita }+ \text { ferrita } \\
\text { acicular refinada }\end{array}$ & $\begin{array}{l}\text { Catódico: Sem aplicação de } \\
\text { potencial ou corrente; solução } \\
\text { NACE TM0177-A: } 5 \% \mathrm{NaCl}+ \\
0,5 \% \text { ácido acético + saturação } \\
\text { com } \mathrm{H}_{2} \mathrm{~S} \text {. } \\
\text { Anódico: } \mathrm{E}=+250 \mathrm{mV} / \mathrm{SCE} ; 0,1 \\
\mathrm{M} \mathrm{NaOH} \text {. } \\
\text { Meio desaerado (injeção de } \mathrm{N}_{2} \text { ); } \\
\text { célula de carregamento desaerada } \\
+ \text { injeção de } \mathrm{H}_{2} \mathrm{~S} \text {. }\end{array}$ & $\begin{array}{l}\text { Não calculado; } \\
\text { apresentação } \\
\text { das curvas de } \\
\text { permeabilidade } \\
\text { e relação do } \\
\text { valor da } \\
\text { corrente de } \\
\text { estado } \\
\text { estacionário } \\
\text { com fração de } \\
\text { ferrita acicular. }\end{array}$ \\
\hline
\end{tabular}


Os artigos de Haq et al [32] e de Fallahmohammadi et al [31] contém tabelas similares à Tabela 5, e podem ser consultados para mais exemplos de condições de ensaio e resultados obtidos, ou como guias para busca de trabalhos.

\subsection{Difusão do $H$ pela ferrita, influência de textura, de bandeamento e de contornos de grão ferríticos}

De acordo com Jiang e Carter [75], a difusividade do H à temperatura ambiente na ferrita pura é alta, da ordem de $1 \times 10^{-4} \mathrm{~cm}^{2}$. $\mathrm{s}^{-1}$ (o C e o $\mathrm{N}$ têm difusividades da ordem de $1 \mathrm{x}$ $10^{-16} \mathrm{~cm}^{2} . \mathrm{s}^{-1}$ ) [75]. É bem estabelecido pela literatura que os átomos de $\mathrm{H}$, devido a seu pequeno diâmetro ( 1 $\AA$ [69]), quando não ligados a algum trap, ocupam os sítios intersticiais do ferro BCC $[53,55,59,75]$ e, preferencialmente, os sítios tetraédricos $[59,63,75]$. O raio do sítio tetraédrico é duas vezes maior que do sítio octaédrico e, portanto, é capaz de acomodar melhor os átomos de H [58]; Counts et. al. [63] e Jiang e Carter [75] mostraram através de cálculos de DFT que o sítio tetraédrico é o mais estável para o H.

A difusão de átomos pela rede, assim como outras propriedades, como tensões mecânicas, condutividade elétrica e propriedades ópticas, depende da orientação cristalográfica e, conseqüentemente, da textura (orientação preferencial de cristais em um agregado policristalino) $[76,77,78]$.

Cao et. al. [78] estudaram a influência de textura em parâmetros de permeabilidade ao $\mathrm{H}$, dentre eles o coeficiente de difusão efetiva do $\mathrm{H}$, em membranas de níquel policristalinas, com estrutura cristalina do tipo CFC. Membranas com texturas (111), (110), (100) e aleatória (sem textura) foram submetidas a ensaios de permeabilidade ao $\mathrm{H}$ e os autores encontraram os seguintes resultados: (1) a membrana com textura aleatória apresentou o coeficiente de difusão efetiva de $\mathrm{H}$ mais baixo de todos e (2) para as membranas com textura, o coeficiente de difusão efetiva do $\mathrm{H}$ foi mais alto para a membrana com textura (111), seguido da (110) e, por último, da (100) [78]. Os coeficientes de difusão foram determinados por meio de tratamento matemático igual ao descrito na seção 3.5 do presente trabalho e a Tabela 6 apresenta seus valores como relatados por Cao et. al. [78].

Cao et. al. observaram que o coeficiente de difusão efetiva do $\mathrm{H}$ é maior para as estruturas cristalinas que são mais abertas [78]. No caso da estrutura CFC, planos $\{111\}$ são os de maior densidade atômica e, como conseqüência, são os mais amplamente espaçados [78, 79]. 
Tabela 6. Coeficientes de difusão efetiva do $\mathrm{H}$ em membranas de níquel policristalino com diferentes texturas, obtidos por Cao et. al. [78].

\begin{tabular}{|c|c|}
\hline Estrutura superficial da membrana & Coeficiente de difusão efetiva do $\mathbf{H}\left(\mathbf{1 0}^{\mathbf{- 9}} \mathbf{c m}^{\mathbf{2}} \mathbf{.} \mathbf{- 1}^{\mathbf{- 1}}\right) \mathbf{\pm \mathbf { 5 } \%}$ \\
\hline Sem textura & 2,6 \\
\hline$(100)$ & 3,4 \\
\hline$(110)$ & 6,5 \\
\hline$(111)$ & 8,5 \\
\hline
\end{tabular}

Para a estrutura CCC apresentada pela ferrita, os planos de maior densidade atômica são os da família $\{110\}$ e, portanto, estes tendem a ser mais abertos [79] e podem facilitar a difusão do H. Segundo Jiang e Carter [75], as superfícies (100) e (110) de monocristais de Fe CCC (ferrita) são as mais favoráveis para entrada e difusão dos átomos de $\mathrm{H}$ para o bulk [75].

A textura também tem efeitos em outras propriedades, como resistência ao HIC, e o seu controle consiste em uma das abordagens atuais estudadas para melhorar a resistência à fragilização por $\mathrm{H}$ dos aços [26, 80, 81].

Outra característica microestrutural conhecida por influenciar a difusividade do $\mathrm{H}$ em um aço é o bandeamento. É bem estabelecido pela literatura [64, 82, 83] que, à temperatura ambiente e em um aço com microestrutura composta por bandas de ferrita e de perlita, o H irá se difundir preferencialmente pelos contornos de grão ferríticos, presentes nas bandas de ferrita, e pelas interfaces de ferrita-perlita (ou seja, a interface entre as duas bandas). As colônias de perlita, por sua vez, atuam como barreiras para a movimentação dos átomos de $\mathrm{H}$.

Tau e Chan [64] publicaram em 1996 um artigo que discute o efeito do bandeamento na difusividade do H. O estudo foi realizado em uma chapa de aço AISI 4130, que previamente passou por laminação controlada, em duas condições: (I) como recebida, com microestrutura formada por bandas de perlita e de ferrita, e (II) após tratamentos térmicos de homogeneização e de reaustenitização, para que a microestrutura deixasse de ser bandeada e se tornasse homogênea, com tamanho de grão próximo ao do material como recebido. Então, os autores verificaram a influência de dois tipos de microestrutura na permeabilidade e difusividade do H: microestrutura bandeada, composta por ferrita e perlita, e microestrutura aleatória e homogênea, também composta por ferrita e perlita [64]. Foram encontradas diferenças significativas para o Deff do aço AISI 4130 como recebido, ou seja, bandeado, em função da direção ensaiada; para Tau e Chan [64], o Deff diminuiu na sequência: longitudinal, transversal e topo. Essa diminuição do Deff foi relacionada à presença de placas/ilhas de perlita atuando como obstáculos na direção de fluxo considerada. Na seção do topo da chapa, 
os átomos de $\mathrm{H}$ precisam contornar o volume da placa/ilha de perlita para se moverem, ou passarem por suas lamelas, enfrentando assim alta densidade de interfaces ferrita/cementita. Já na seção longitudinal, devido à microestrutura em bandas, com grãos alongados e orientados na direção de laminação, o H se difunde mais facilmente ao longo das bandas de ferrita, que possuem menor quantidade de interfaces para aprisionar os átomos de $\mathrm{H}$ do que as bandas de perlita. Já para a microestrutura aleatória, homogênea e livre de bandeamento, os valores de $\mathrm{D}_{\text {eff }}$ para as três seções foram aproximadamente iguais [64]. 


\section{Materiais e Métodos}

\subsection{Materiais}

As composições químicas dos aços HSLA para fabricação de tubos API grau X65 são apresentadas pela Tabela 7 abaixo. Ambos foram recebidos na forma de chapas, obtidas pelo processo termomecânico de laminação controlada (TMCR).

Tabela 7. Composições químicas dos aços HSLA API grau X65 estudados.

\begin{tabular}{|c|c|c|c|c|c|c|c|c|c|c|c|c|}
\hline Aço & $\mathbf{C}$ & $\mathbf{S i}$ & $\mathbf{M n}$ & $\mathbf{P}$ & $\mathbf{S}$ & $\mathbf{C r}$ & $\mathbf{N i}$ & $\mathbf{A l}_{\text {total }}$ & $\mathbf{C u}$ & $\mathbf{N b}$ & $\mathbf{T i}$ & $\mathbf{N}$ \\
\hline Baixo Mn & 0,038 & 0,223 & 0,533 & 0,007 & 0,0011 & 0,441 & 0,139 & 0,023 & 0,267 & 0,089 & 0,011 & 0,0048 \\
\hline Alto Mn & 0,095 & 0,230 & 1,490 & 0,018 & 0,002 & - & - & 0,044 & - & 0,048 & $0,015^{* *}$ & 0,005 \\
\hline
\end{tabular}

A chapa de aço baixo $\mathrm{Mn}$ apresentava espessura de $16 \mathrm{~mm}$, enquanto que a de alto $\mathrm{Mn}$ tinha espessura de $17 \mathrm{~mm}$. A chapa de aço baixo Mn foi recentemente desenvolvida pela POSCO e seus processos de fabricação e de laminação envolveram as mais altas tecnologias, para obter limpeza e homogeneidade microestrutural - características muito importantes para a aplicação em ambientes ricos em $\mathrm{H}_{2} \mathrm{~S}$, que facilmente podem fragilizar uma estrutura metálica. Já o aço alto Mn foi produzido há, pelo menos, 10 anos, pela antiga COSIPA, atual USIMINAS, e foi projetado para aplicação em ambientes doces, nos quais a resistência à fragilização por hidrogênio não é um requisito tão importante.

\subsection{Métodos}

\subsubsection{Caracterização Microestrutural por Microscopia Óptica e Eletrônica de Varredura}

Para os dois aços foram analisadas as microestruturas das seções longitudinal, transversal (em relação à direção de laminação) e do topo da chapa. Na Figura 19 é apresentada uma esquematização das seções avaliadas. As amostras foram lixadas até 1000 meshes, polidas com suspensões de diamante de 6, 3 e $1 \mu \mathrm{m}$ e, por fim, atacadas com Nital $2 \%$. 




Figura 19. Faces da chapa analisadas com relação à direção de laminação (DL).

Para caracterização dos microconstituintes após ataque com Nital 2\%, as amostras das duas chapas de aço foram observadas ao longo de sua espessura e, como seus formatos eram retangulares, fez-se a seguinte delimitação de regiões para análise, ilustrada pela Figura 20: (i) borda superior, (ii) 1/4 borda superior, (iii) centro, (iv) 1/4 borda inferior e (v) borda inferior.



Figura 20. Representação das regiões das amostras analisadas por microscopia.

Para análise das inclusões presentes, os dois aços foram observados através do microscópio óptico sem ataque, apenas com as superfícies lixadas e polidas. Em cada seção analisada, fez-se uma varredura com o microscópio óptico, em aumento de 100 x e com base na norma ASTM E45-13 [84], de modo a se obter 9 imagens/seção. A Figura 21 apresenta uma esquematização desta varredura, com indicação dos pontos analisados. 


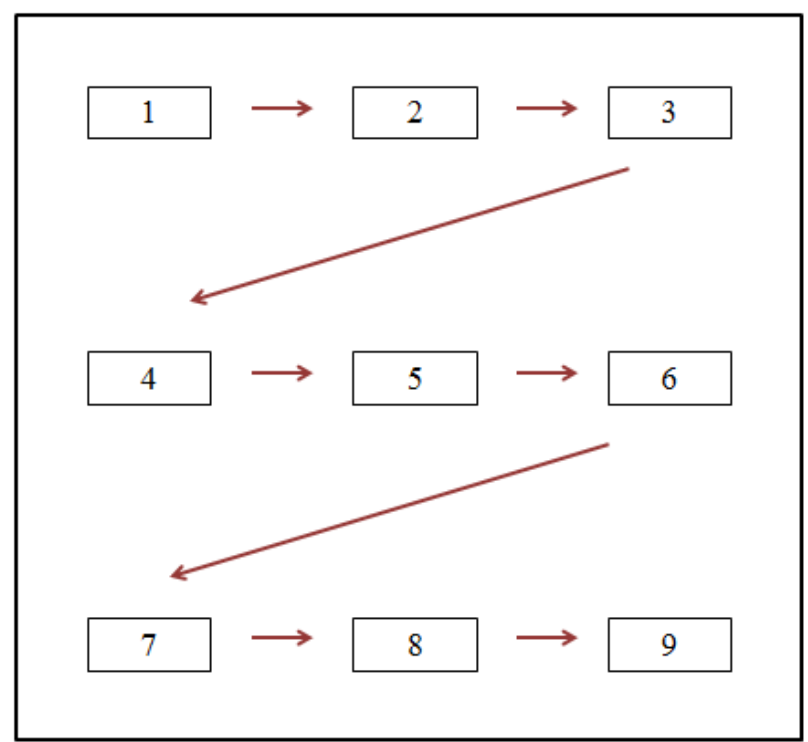

Figura 21. Esquematização da varredura superficial, para cada seção, feita com o microscópio óptico para análise das inclusões.

Dessa forma foi possível ter uma visão geral das inclusões ao longo das espessuras das chapas, ou seja, de suas formas, distribuição e dispersão pela superfície.

As imagens de microscopia óptica foram adquiridas com microscópio Olympus BX60M, acoplado com sistema de aquisição de imagens Altra 20, localizado no Laboratório de Caracterização Microestrutural "Hubertus Colpaert", do PMT-EPUSP; as imagens de microscopia eletrônica de varredura e análises químicas foram obtidas com microscópio eletrônico de varredura com emissão de campo FEI Inspect F50, acoplado com EDS EDAX, pertencente ao LabMicro do PMT-EPUSP.

\subsubsection{Microdureza Vickers}

Medidas de microdureza Vickers foram realizadas com base na norma ASTM E 38411 [85] para todos os tipos de amostras estudados. Para as amostras longitudinais e transversais as medidas foram feitas ao longo da espessura e para as amostras dos topos das chapas, de modo aleatório pelas superfícies. Os parâmetros usados para fazer as medidas são apresentados pela Tabela 8 abaixo. O equipamento usado foi o microdurômetro Shimadzu HMV-2TQDW, localizado no LabMicro do PMT-EPUSP. 
Tabela 8. Parâmetros usados para as medidas de microdureza Vickers.

\begin{tabular}{|c|c|c|c|}
\hline Tipo de penetrador & Carga & $\begin{array}{c}\text { Tempo de aplicação } \\
\text { da carga }\end{array}$ & $\begin{array}{c}\text { Total de medidas } \\
\text { por amostra }\end{array}$ \\
\hline Piramidal & $0,3 \mathrm{~kg}$ & $10 \mathrm{~s}$ & 10 \\
\hline
\end{tabular}

\subsubsection{Metalografia quantitativa}

\subsubsection{Determinação de frações volumétricas de microconstituintes}

As medidas de fração volumétrica dos microconstituintes, para os dois aços, foram feitas com o analisador de imagens Leica Application Suite - LAS 4,5 da Leica, no Laboratório de Petrografia Sedimentar (LabPetro) do Instituto de Geociências da USP, e com base na norma ASTM E1245-03 [86]. Foram analisadas, em cada seção dos aços, 9 imagens de elétrons secundários, em aumento de $2500 \mathrm{x}$, totalizando 54 imagens para serem medidas (seções longitudinal, transversal e topo dos aços baixo e alto $\mathrm{Mn}$ ).

Imagens obtidas por MEV são dadas em tons de cinza e, apesar de ser possível diferenciar microconstituintes com base em suas diferentes tonalidades e morfologias, o analisador não é capaz de fazer essa distinção, visto que a microestrutura como um todo não apresenta regiões de cores bem definidas. Para resolver esta questão, foi preciso contornar os microconstituintes desejados, em cada imagem, com a cor vermelha.

O analisador é capaz de medir uma série de parâmetros, dentre eles a área dos microconstituintes detectados. A fração volumétrica $\left(\mathrm{V}_{\mathrm{V}}\right)$ é obtida a partir da fração de área; esta última é dada pela Equação 7 a seguir:

$$
\mathrm{A}_{\mathrm{A}}=\frac{\mathrm{A}_{\mathrm{i}}}{\mathrm{A}_{\mathrm{T}}}
$$

Onde: $A_{A}=$ fração de área; $A_{i}=$ área (soma) dos componentes detectados em cada campo; $\mathrm{A}_{\mathrm{T}}=$ área do campo de medida.

Como $\mathrm{V}_{\mathrm{v}}=\mathrm{A}_{\mathrm{A}}$, a fração volumétrica é calculada diretamente com a equação (7). 


\subsubsection{Determinação de tamanho de grão}

No aço com $0,5 \%$ em massa de Mn, o tamanho de grão foi calculado de acordo com o método planimétrico [87]. Para cada seção, foram usadas 6 imagens obtidas no microscópio óptico, após ataque com Nital 2\%, com aumento de $500 \mathrm{x}$ - a norma pede um número mínimo de 3 campos para que se possa fazer uma média razoável dos valores. Em cada imagem, traçou-se uma circunferência com raio $\mathrm{r}=39,89 \mathrm{~mm}$, ou seja, com área de $5000 \mathrm{~mm}^{2}$, como pede a norma ASTM E112-13 [87]; foram contados pelo menos 50 grãos por área de circunferência. Usando a escala do microscópio óptico é possível fazer a conversão do tamanho da circunferência, medido em $\mathrm{mm}$, para $\mu \mathrm{m}^{2}$, unidade compatível com a magnificação do microscópio óptico e com a microestrutura do aço.

A norma utiliza algumas equações para determinação da área média do grão, em mm².

São as seguintes:

$$
\begin{gathered}
\mathrm{N}_{\mathrm{T}}=\mathrm{N}_{\mathrm{i}}+\frac{1}{2}\left(\mathrm{~N}_{\text {inter }}\right) \\
\mathrm{N}_{\mathrm{A}}=\mathrm{f}\left(\mathrm{N}_{\mathrm{T}}\right) \\
f=M^{2} / A \\
\bar{A}=1 / \mathrm{N}_{\mathrm{A}}
\end{gathered}
$$

Onde:

$\mathrm{N}_{\mathrm{i}}=$ grãos no interior da circunferência;

$\mathrm{N}_{\text {inter }}=$ grãos interceptados pela circunferência;

$\mathrm{N}_{\mathrm{T}}=$ total de grãos contados;

$\mathrm{N}_{\mathrm{A}}=$ número de grãos. $\mathrm{mm}^{-2}$;

$\mathrm{f}=$ multiplicador de Jeffries;

$\mathrm{M}$ = magnificação do microscópio;

$\mathrm{A}=$ área da circunferência, em $\mathrm{mm}^{2} \mathrm{e}$

$\overline{\mathrm{A}}=$ área média do grão, em $\mathrm{mm}^{2}$.

Como a escala de micrografia usada foi diferente da utilizada pela norma, para dedução das equações (9) e (10), não se pode aplicar o multiplicador de Jeffries na obtenção do número de grãos.mm ${ }^{-2}$. O uso direto das equações (8) a (11), sem a conversão de área da 
circunferência traçada a partir da escala da micrografia, leva a resultados completamente errados, não condizentes com o que é observado nas micrografias. Em vez de usar o multiplicador de Jeffries, nesses casos, o correto é fazer a conversão do tamanho da circunferência de $\mathrm{mm}^{2}$ (medidos manualmente, com uso de régua ou do recurso do analisador de imagens) para $\mu \mathrm{m}^{2}$, como explicado anteriormente. Então, o novo valor da área, em $\mu \mathrm{m}^{2}$, precisa ser convertido novamente para $\mathrm{mm}^{2}$, para que se possa calcular o $\mathrm{N}_{\mathrm{A}}$ com a equação 12 abaixo:

$$
N_{A}=\mathrm{N}_{\mathrm{T}} / \mathrm{A}_{\text {corrigida }}
$$

Em que: $\mathrm{A}_{\text {corrigida }}=$ área da circunferência, em mm², após a conversão a partir da escala da micrografia.

Os valores e etapas para o cálculo da $\mathrm{A}_{\text {corrigida }}$ são apresentados pela Tabela 9; os parâmetros e equações modificadas do método de Jeffries são apresentadas pela Tabela 10.

Tabela 9. Valores e etapas para cálculo de $\mathrm{A}_{\text {corrigida. }}$

\begin{tabular}{|c|c|c|c|c|c|}
\hline $\begin{array}{c}\text { Raio da } \\
\text { circ. } \\
(\mathbf{m m})\end{array}$ & $\begin{array}{c}\text { Área da } \\
\text { circ. } \\
\left(\mathrm{mm}^{2}\right)\end{array}$ & $\begin{array}{l}\text { Valor, em mm, da barra } \\
\text { de escala de } 50 \mu \mathrm{m} \text { da } \\
\text { micrografia (aumento de } \\
500 \mathrm{x} \text { ) }\end{array}$ & $\begin{array}{l}\text { Raio da } \\
\text { circ. }(\mu \mathrm{m})\end{array}$ & $\begin{array}{c}\text { Área da } \\
\text { circ. } \\
\left.\left(\mu^{2}\right)^{2}\right)\end{array}$ & $\begin{array}{c}\mathbf{A}_{\text {corrigida }} \\
\left(\mathbf{m m}^{2}\right)\end{array}$ \\
\hline 39,89 & 4998,94 & 48 & 41,55 & 5423,65 & $5,42 \times 10^{-3}$ \\
\hline
\end{tabular}

Tabela 10. Parâmetros e equações usados alterados para determinação do tamanho de grão com base no método de Jeffries.

\begin{tabular}{|c|c|c|}
\hline $\mathrm{N}_{\mathrm{T}}$, total de grãos contados & $\mathrm{N}_{\mathrm{A}}\left(\right.$ grãos.mm $\left.{ }^{-2}\right)$ & $\overline{\mathbf{A}},\left(\mathbf{m m}^{2}\right)$ \\
\hline $\mathrm{N}_{\mathrm{T}}=\mathrm{N}_{\mathrm{i}}+\frac{1}{2}\left(\mathrm{~N}_{\text {inter }}\right)$ & $N_{A}=\mathrm{N}_{\mathrm{T}} / \mathrm{A}_{\text {corrigida }}$ & $\bar{A}=1 / \mathrm{N}_{\mathrm{A}}$ \\
\hline
\end{tabular}

O método usado para determinação do tamanho de grão do aço com alto $\mathrm{Mn}$ foi diferente. O aço baixo $\mathrm{Mn}$, como será visto no tópico Resultados e Discussão, tem microestrutura que pode ser considerada monofásica e, por esta razão, não houve problemas para se calcular o tamanho de grão pela metodologia de Jeffries. O aço com alto Mn, no entanto, é composto por dois principais microconstituintes e o cálculo do tamanho de grão, 
nesse caso, se torna um pouco mais complexo. O método do intercepto linear de Heyn é particularmente útil nesse caso. Com ele é possível contar os grãos interceptados por linhas retas, que podem ser paralelas ou apresentar diferentes orientações. A sua utilidade em materiais com mais de uma fase se dá ao permitir que a contagem dos grãos seja realizada em regiões específicas da micrografia, nas quais somente a fase de interesse esteja presente requisito, segundo a norma ASTM E112-13 [87], para fazer qualquer tipo de medição em materiais com várias fases presentes.

Assim, uma grade composta por 8 linhas horizontais e paralelas foi sobreposta a cada imagem e contaram-se os grãos de interesse interceptados por cada linha $\left(\mathrm{N}_{\text {inter } \alpha}\right)$. Para cada seção do material foram feitos 6 campos de imagem e medições em 6 das 8 linhas da grade dessa forma garantiu-se um mínimo de 50 grãos contados por imagem. As imagens foram obtidas com o microscópio, com aumento de 500 x. Assim como foi feito no caso anterior, o comprimento total da linha, inicialmente em $\mathrm{mm}$, foi convertido para $\mu \mathrm{m}$ e, depois, transformado em mm novamente. A conversão final para mm é necessária porque as equações da norma foram todas deduzidas para se trabalhar nesta unidade de medida - o uso destas equações com valores em $\mu \mathrm{m}$ leva a resultados equivocados, que não concordam com a microestrutura observada através das micrografias. Para o cálculo do intercepto médio linear $\bar{l}_{\alpha}$, são usadas as equações (13) e (14).

$$
\begin{gathered}
N_{L}=N_{\text {inter }} / L_{\text {corrigido }} \\
\bar{l}_{\alpha}=\left(1 / N_{L}\right) V_{V \alpha}
\end{gathered}
$$

Onde:

$\mathrm{N}_{\mathrm{L}}=$ número de grãos $/ \mathrm{mm}$;

$\mathrm{N}_{\text {inter }}=$ número de grãos interceptados pela linha de teste;

$\mathrm{L}_{\text {corrigido }}=$ comprimento da linha de teste após as conversões, para adequação à micrografia, em mm;

$\overline{l_{\alpha}}=$ intercepto médio linear do microconstituinte de interesse, em mm (pode ser transformado em $\mu \mathrm{m}$, fazendo-se a multiplicação do seu valor por 1000) e

$V_{V \alpha}=$ fração volumétrica do microconstituinte de interesse.

A Tabela 11 mostra o passo a passo para conversão dos valores de linha de teste adotado, assim como foi feito na Tabela 9, e resume as características da grade. 
Tabela 11. Parâmetros e equações para determinação do tamanho de grão pelo método do intercepto linear de Heyn.

\begin{tabular}{|c|c|c|c|c|}
\hline $\begin{array}{c}\text { Comprimento } \\
\text { de } 1 \text { linha da } \\
\text { grade (mm) }\end{array}$ & $\begin{array}{c}\text { L (mm) }-\mathbf{6} \\
\text { linhas usadas } \\
\text { para medição }\end{array}$ & $\begin{array}{c}\text { Valor, em mm, da barra de } \\
\text { escala de } \mathbf{5 0} \boldsymbol{\mu m} \text { da } \\
\text { micrografia (aumento de }\end{array}$ & $\begin{array}{c}\text { L } \\
(\boldsymbol{\mu m})\end{array}$ & $\begin{array}{c}\mathbf{L}_{\text {corrigido }} \\
(\mathbf{m m})\end{array}$ \\
\hline 224 & 1344 & $\mathbf{5 0 0} \mathbf{x})$ & \multirow{2}{*}{1400} & 1,4 \\
\hline
\end{tabular}

\subsubsection{Determinação de área de contornos de grão por unidade de volume $\left(S_{v}\right)$}

Medidas quantitativas da área de contornos de grão por unidade de volume $\left(\mathrm{S}_{\mathrm{v}}\right)$ foram realizadas. Para o aço com $0,5 \%$ em massa de $\mathrm{Mn}$, o método usado foi o de intercepto circular de Hilliard [87], em micrografias obtidas por elétrons secundários com aumento de $2500 \mathrm{x}$. Este método é recomendado para quando se trabalha com materiais deformados, que apresentam grãos não-equiaxiais, uma vez que, com uma única circunferência traçada, grãos com diferentes orientações podem ser analisados - com um método linear isso não seria possível; várias linhas precisariam ser traçadas, uma para cada orientação.

Por se tratar de um método de intercepto, as conversões de medidas em mm para $\mu \mathrm{m}$ foram feitas de maneira igual à apresentada no tópico anterior. A Tabela 12 apresenta os parâmetros usados para o cálculo de $S_{\mathrm{v}}$ e a Equação 15 mostra a fórmula utilizada.

$$
\mathrm{Sv}=2 \mathrm{~N}_{\mathrm{L}}
$$


Tabela 12. Dados usados para o cálculo de $S_{\mathrm{v}}$.

\begin{tabular}{|c|c|c|c|}
\hline $\begin{array}{c}\text { Diâmetro da } \\
\text { circunferência } \\
(\mathbf{m m})\end{array}$ & $\begin{array}{c}\text { Valor, em mm, da barra de } \\
\text { escala de } \mathbf{5 0} \boldsymbol{\mu m} \text { da } \\
\text { micrografia (aumento de } \\
\mathbf{2 5 0 0} \mathbf{x})\end{array}$ & $\begin{array}{c}\text { L, perímetro } \\
\text { da } \\
\text { circunferência }\end{array}$ & $\begin{array}{c}\mathbf{L}_{\text {corrigido }} \\
(\mathbf{m m})\end{array}$ \\
\hline 100 & $(\boldsymbol{\mu m})$ & \\
\hline & & 1400 & 1,4 \\
\hline
\end{tabular}

Para o aço com alto Mn, utilizou-se para contagem dos grãos o método do intercepto linear de Heyn, já descrito no item 4.2.3.2, com a mesma grade de linhas horizontais da Tabela 11, a equação de $\mathrm{N}_{\mathrm{L}}$ apresentada pela Equação 13 e, para o cálculo de $\mathrm{S}_{\mathrm{v}}$, como se trata de material com mais de uma fase, utilizou-se a Equação 16 abaixo, retirada da norma ASTM E112-13 [87]:

$$
S_{V}=4 N_{L}
$$

Como a contagem dos grãos é feita para somente um microconstituinte, o $\mathrm{N}_{\mathrm{L}}$ é multiplicado por 4, para compensar as interfaces que não foram consideradas com os grãos do outro tipo de microconstituinte.

Assim como para o aço baixo Mn, foram usadas micrografias de elétrons secundários e aumento de $2500 \mathrm{x}$ e, também para efeito de comparação, calculou-se o valor de $S_{\mathrm{v}}$ para o aço baixo Mn com o método do intercepto linear.

\subsubsection{Difração de Elétrons Retroespalhados (EBSD)}

Quando empregada como uma ferramenta adicional de caracterização no MEV, a técnica de EBSD permite a determinação da orientação de grãos individuais, de textura local, correlações de orientação ponto a ponto e identificação de fases e suas distribuições, tamanho de grão, comprimento de contornos de grão, entre várias outras [88].

Um padrão de EBSD é obtido a partir da superfície plana de uma amostra da seguinte maneira: um feixe estacionário de elétrons é posicionado na amostra, no interior do MEV, e os elétrons retroespalhados pelo volume do material são difratados pelos planos cristalinos segundo a Lei de Bragg [89]. Como os elétrons retroespalhados são facilmente absorvidos 
pela amostra, a mesma deve ser inclinada em $70^{\circ}$ para que uma quantidade suficiente de dados possa ser gerada [89]. Os padrões de difração assim obtidos são coletados por uma tela de fósforo; apresentam-se na forma de linhas claras, paralelas e arranjadas de forma regular, e são chamados de Linhas de Kikuchi ou Padrões de Kikuchi - estes padrões fornecem as informações sobre a cristalografia do material [88].

O preparo de amostras para EBSD é trabalhoso e delicado, sendo muito importante que a superfície da amostra já apresente alta planicidade assim que for cortada. Isso foi conseguido utilizando a cortadeira Secotom-10 da Struers. Também faz muita diferença, durante o preparo, trabalhar com amostras de pequenas dimensões, de, no máximo, $1 \mathrm{~cm}^{2} \mathrm{de}$ área - é difícil distribuir a pressão sobre a amostra de maneira homogênea quando as suas dimensões são grandes, o que resulta em heterogeneidades no paralelismo da superfície e impede que o padrão seja obtido em toda área analisada.

A preparação da amostra foi feita com base nas considerações de Koll et. al. [90] e de Ariza [91]. A Tabela 13 resume os passos e parâmetros adotados para preparo da amostra. Quanto menor o tempo de permanência nas lixas e panos, menor é a formação de planos de deformação na superfície da amostra, que impedem a obtenção do padrão de EBSD. Assim, como a qualidade do corte com cortadeiras de precisão é alta, não se faz necessário o uso de lixas inferiores a 600 meshes.

As análises de EBSD foram realizadas com o MEV com emissão de campo FEI Inspect F50, acoplado com câmara EDAX de difração de elétrons retroespalhados, pertencente ao LabMicro do PMT-EPUSP. O principal intuito destas análises foi o de detectar presença de textura nas diferentes faces dos aços; adicionalmente à textura, utilizaram-se as informações sobre tamanho de grão e comprimento de contorno de grão (contornos de baixo e alto ângulo). O software usado para tratamento dos dados de EBSD foi o TSL OIM Analysis 7 $x 64$. Três áreas escolhidas aleatoriamente de cada amostra foram analisadas; o aumento usado foi de $1500 \mathrm{x}$ e o passo (step-size) de $0,8 \mu \mathrm{m}$. 
Tabela 13. Etapas para preparo de amostras para EBSD e os parâmetros adotados.

\begin{tabular}{|c|c|c|c|c|}
\hline \multicolumn{5}{|c|}{ Lixamento } \\
\hline Abrasivo & \multicolumn{3}{|c|}{$\mathrm{SiC}$} & $\mathrm{SiC}$ \\
\hline Lixa (mesh) & \multicolumn{3}{|c|}{$\# 600$} & $\# 1000$ \\
\hline Lubrificante & \multicolumn{3}{|c|}{ Água } & Água \\
\hline $\begin{array}{c}\text { Velocidade } \\
\text { de rotação } \\
\text { da lixadeira } \\
\text { (RPM) }\end{array}$ & \multicolumn{3}{|c|}{300} & 300 \\
\hline Força $(\mathbf{N})$ & \multicolumn{3}{|c|}{30} & 30 \\
\hline $\begin{array}{c}\text { Tempo } \\
\text { (min) }\end{array}$ & \multicolumn{3}{|c|}{1} & 1 \\
\hline \multicolumn{5}{|c|}{ Polimento } \\
\hline Abrasivo & $\begin{array}{c}\text { Suspensão } \\
\text { de } \\
\text { Diamante }\end{array}$ & $\begin{array}{l}\text { Suspensão } \\
\text { de } \\
\text { Diamante }\end{array}$ & $\begin{array}{l}\text { Suspensão } \\
\text { de } \\
\text { Diamante }\end{array}$ & $\begin{array}{c}\text { Sílica (uso da VibroMet, da } \\
\text { Buehler) }\end{array}$ \\
\hline $\begin{array}{l}\text { Tamanho de } \\
\text { partícula } \\
(\mu \mathrm{m})\end{array}$ & 6 & 3 & 1 & 0,02 \\
\hline Lubrificante & Álcool & Álcool & Álcool & Água destilada \\
\hline $\begin{array}{c}\text { Velocidade } \\
\text { de rotação } \\
\text { da politriz } \\
\text { (RPM) }\end{array}$ & 150 & 150 & 150 & 30 \\
\hline Força $(\mathbf{N})$ & 3 & 3 & 3 & 3 \\
\hline $\begin{array}{c}\text { Tempo } \\
\text { (min) }\end{array}$ & $1-2 \min$ & $1-2 \min$ & $10-20 \mathrm{~min}$ & $180 \mathrm{~min}$ \\
\hline
\end{tabular}




\subsubsection{Permeabilidade ao hidrogênio}

Todas as amostras foram cortadas na forma de lâminas com espessuras de, aproximadamente, $1 \mathrm{~mm}$. Os ensaios foram realizados baseados na Norma ASTM G 148-97 [40], seguindo a metodologia desenvolvida pelo grupo de pesquisa do LPE/LabH2S do Departamento de Engenharia Metalúrgica e de Materiais da EPUSP [92] e utilizando as dependências deste mesmo laboratório.

O procedimento pode ser dividido em quatro etapas: preparo das amostras para o ensaio, recobrimento metálico (niquelação) de uma das faces da amostra, remoção do hidrogênio da amostra (decaimento) e permeabilidade de hidrogênio. Após o corte das amostras em lâminas de $\sim 1 \mathrm{~mm}$ de espessura, uma de suas faces foi lixada até 600 meshes e, a outra, até 1200 meshes. Nesta segunda face foi feito o recobrimento com níquel (niquelação), para impedir a sua corrosão nas etapas seguintes. A Figura 22 e a Tabela 14 mostram, respectivamente, a célula eletroquímica e a composição do eletrólito usados durante a niquelação.

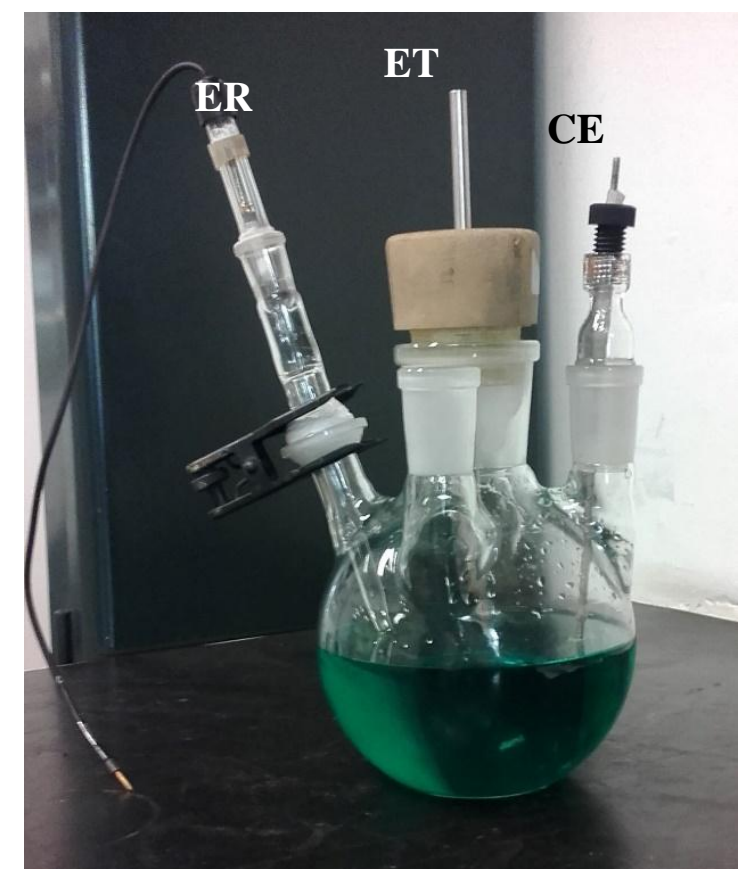

Figura 22. Célula eletroquímica usada para niquelação; $\mathrm{CE}=$ contra-eletrodo de níquel, $\mathrm{ER}=$ eletrodo de referência de calomelano saturado e ET = eletrodo de trabalho (amostra a ser niquelada). 
Tabela 14. Composição química do eletrólito para niquelação. Valores de \% em massa para o preparo de $1 \mathrm{~L}$ de solução.

\begin{tabular}{|c|c|}
\hline Reagente & $\begin{array}{c}\text { \% em massa, } \\
\text { por L }\end{array}$ \\
\hline $\mathrm{NiSO}_{4} \cdot 7 \mathrm{H}_{2} \mathrm{O}$ & $15 \%$ \\
\hline $\mathrm{NH}_{4} \mathrm{Cl}$ & $1,5 \%$ \\
\hline $\mathrm{H}_{3} \mathrm{BO}_{3}$ & $1,5 \%$ \\
\hline $\mathrm{H}_{2} \mathrm{O}$ destilada & $\begin{array}{c}\text { Volume } \\
\text { restante }\end{array}$ \\
\hline
\end{tabular}

$\mathrm{Na}$ Figura 22, ER corresponde ao eletrodo de referência de calomelano saturado, ET é o eletrodo de trabalho (amostra) e CE é o contra eletrodo de níquel, que atua como anodo. Para que a camada de níquel depositada seja homogênea, a amostra deve estar com a superfície em excelentes condições de lixamento e limpeza: os riscos da lixa precisam estar paralelos entre si e a superfície da amostra deve estar livre de gorduras e outras impurezas. Durante a niquelação, hidrogênio gasoso é formado e, portanto, hidrogênio na sua forma atômica pode penetrar a estrutura do material. Por esta razão, deseja-se que o tempo de niquelação seja o mínimo possível para formação de uma camada protetora e, segundo testes realizados por [92], este tempo é de $10 \mathrm{~min}$, para aplicação de potencial catódico que resulte em uma densidade de corrente de $1 \mathrm{~mA} . \mathrm{cm}^{-2}$, e foi adotado para os ensaios.

Para as duas últimas etapas foram usadas duas células eletroquímicas conectadas entre si através da amostra analisada. A Figura 23 apresenta uma fotografia do sistema formado pelas células e a amostra.

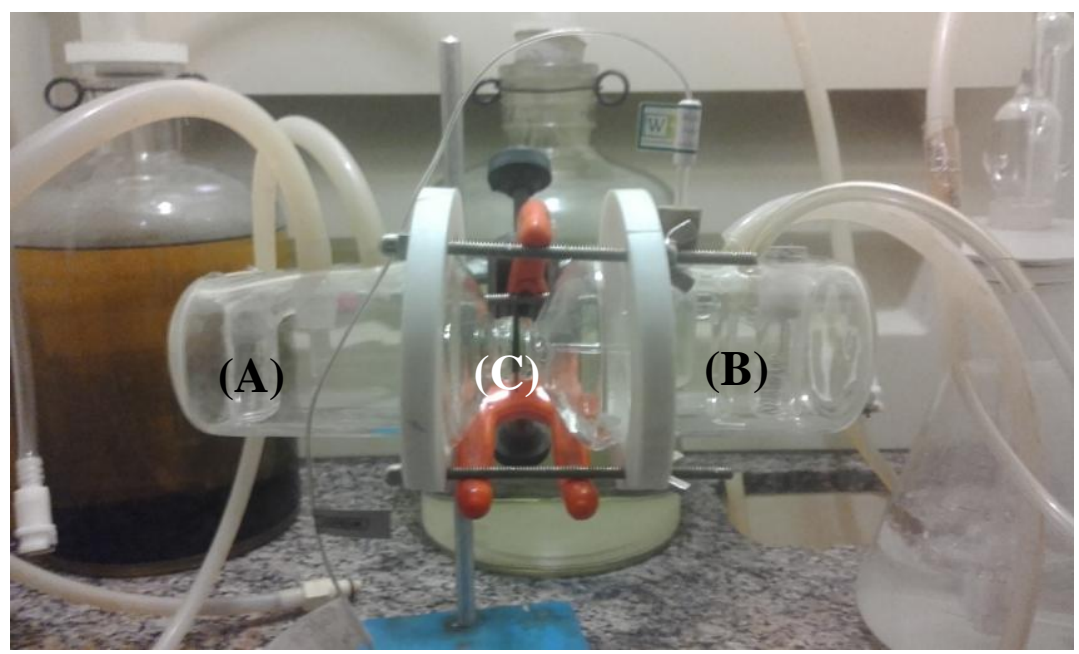

Figura 23. Células eletroquímicas montadas para ensaio de permeabilidade. Em (A) tem-se a célula de geração de hidrogênio, em (B), a célula de oxidação e em (C) a amostra. 
Na Figura 23, a célula de geração de hidrogênio é indicada por (A); a célula de oxidação é indicada por (B) e a amostra, por (C). Para as duas últimas etapas foram usadas duas soluções diferentes, cujas composições químicas são mostradas pela Tabela 15. As células eletroquímicas e as soluções foram desaeradas previamente, por meio da injeção de $\mathrm{N}_{2}$ ao sistema. $\mathrm{Na}$ célula de oxidação são colocados o eletrodo de referência de $\mathrm{Ag} / \mathrm{AgCl}$ e o contra eletrodo de platina; estes dois eletrodos e a amostra (eletrodo de trabalho) são conectados ao potenciostato.

Tabela 15. Eletrólitos usados nas etapas de decaimento e de permeabilidade ao hidrogênio.

\begin{tabular}{|c|c|}
\hline Eletrólito & \multicolumn{1}{|c|}{ Composição } \\
\hline $\begin{array}{c}\text { Solução A } \\
\text { (célula de geração de } \\
\text { hidrogênio) }\end{array}$ & $\begin{array}{l}5 \% \\
\text { destilada, saturada com } \mathrm{H}_{2} \mathrm{~S} \text { e desaerada. Valores para } 1 \mathrm{~L} \\
\text { de solução. }\end{array}$ \\
\hline $\begin{array}{c}\text { Solução } \mathrm{NaOH} \text { (célula de } \\
\text { oxidação) }\end{array}$ & \multicolumn{1}{|c|}{ Solução aquosa e desaerada de $0,2 \mathrm{M} \mathrm{NaOH}}$. \\
\hline
\end{tabular}

Primeiro, a célula de oxidação foi preenchida com a solução desaerada de 0,2 $\mathrm{M}$ $\mathrm{NaOH}$. Com isso, fez-se a remoção de átomos de hidrogênio pré-existentes da amostra, provenientes de processos como a niquelação, mediante a aplicação de potencial de +200 $\mathrm{mV}, \mathrm{Ag} / \mathrm{AgCl}$. Depois, a célula de geração de hidrogênio foi preenchida com solução A desaerada e saturada com $\mathrm{H}_{2} \mathrm{~S}$ para que a etapa de permeabilidade ocorresse, também sob potencial de $+200 \mathrm{mV}, \mathrm{Ag} / \mathrm{AgCl}$.

O potenciostato utilizado foi o PAR 273A da marca EG\&G, juntamente do softwarePower Suite 2.58. A Figura 24 contém fotos de amostra submetida ao ensaio de permeabilidade ao $\mathrm{H}$.
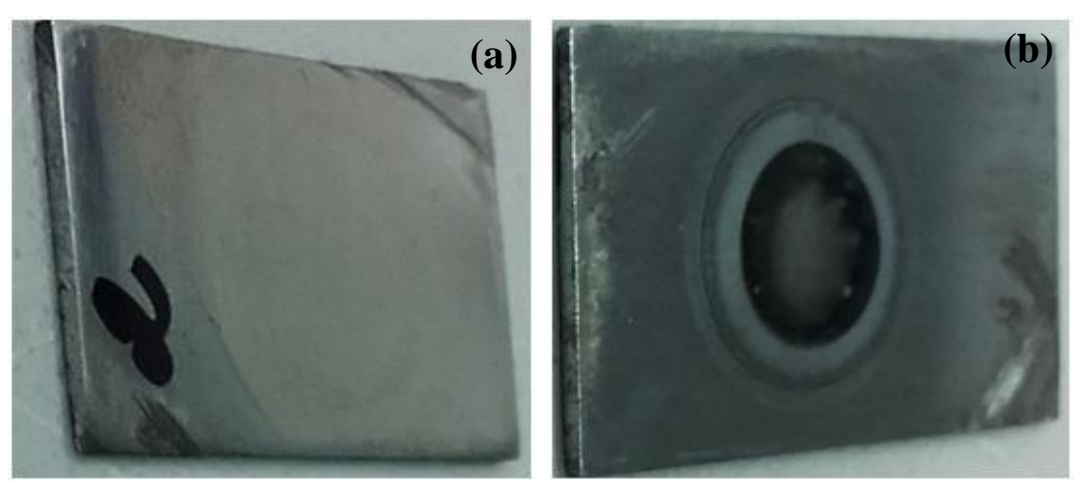

Figura 24. Exemplo de amostra após o ensaio de permeabilidade ao hidrogênio. (a) Face de saída dos átomos de $\mathrm{H}$, niquelada, exposta à célula de oxidação e (b) face de entrada dos átomos de $\mathrm{H}$, exposta à célula de geração de H. 
A Figura 24(a) apresenta a face niquelada e a Figura 24(b), a face de carregamento corroída. A área corroída é delimitada pela marca do o-ring que é colocado nas duas células eletroquímicas para fazer a vedação das mesmas e fixar a amostra entre elas.

Os ensaios foram repetidos até que se conseguisse um mínimo de 3 curvas com perfis próximos do ideal mostrado pela Figura 18, ou seja, que mostrassem apenas as interações do $\mathrm{H}$ com o material. $\mathrm{O}$ ensaio de permeabilidade ao $\mathrm{H}$ é relativamente complexo de ser feito. Qualquer defeito na camada de níquel prejudica completamente a sua execução, pois a amostra sofre corrosão e outros tipos de reações, além da oxidação do $\mathrm{H}$, passam a ser medidas; a montagem do sistema de células e de injeção de gases não é rápida, se houver entrada de ar em alguma das células ou eletrólitos os resultados são comprometidos, entre outros. Estas questões prejudicam a reprodutibilidade da técnica e, por isso, não foi possível fazer um número de repetições que permitissem análise estatística dos dados.

\subsubsection{Análise de Dessorção Térmica}

Técnicas de dessorção térmica são amplamente usadas para medir teor de hidrogênio em aços. Normalmente as amostras são aquecidas de maneira controlada e o gás desprendido é medido por cromatografia ou espectrometria.

Amostras longitudinais, transversais e topo dos dois aços, de espessuras de aproximadamente $1 \mathrm{~mm}$, passaram, primeiro, pelo processo de carregamento com hidrogênio por via eletroquímica e, depois, pelas medidas de dessorção térmica. Os ensaios foram todos realizados no Laboratório Nacional de Nanotecnologia (LNNano), no CNPEM, Barão Geraldo - SP; e o equipamento usado para as análises de dessorção térmica foi o Hydrogen Analyzer G4 HD Phoenix, da Bruker.

\subsubsection{Carregamento com Hidrogênio}

O ensaio de carregamento com $\mathrm{H}$ feito no LNNano é baseado nas normas AWS-A4.3 [93] e ISO 3690-2012 [94] para determinação de hidrogênio em metais soldados. O método é relativamente simples: utiliza solução de $0,5 \mathrm{M}$ de $\mathrm{H}_{2} \mathrm{SO}_{4}$ (para $1 \mathrm{~L}$ de solução, $5,5 \mathrm{~mL}$ de $\mathrm{H}_{2} \mathrm{SO}_{4}$ ) e $10 \mathrm{mg} . \mathrm{L}^{-1}$ de $\mathrm{As}_{2} \mathrm{O}_{3}$ (solução de alta periculosidade, por causa do arsênio, que é o veneno catódico) e aplicação de corrente catódica de $20 \mathrm{~mA} \cdot \mathrm{cm}^{-2}$. Uma fonte de tensão é 
usada para aplicar a corrente catódica. A Figura 25 mostra o arranjo experimental para o carregamento com $\mathrm{H}$.

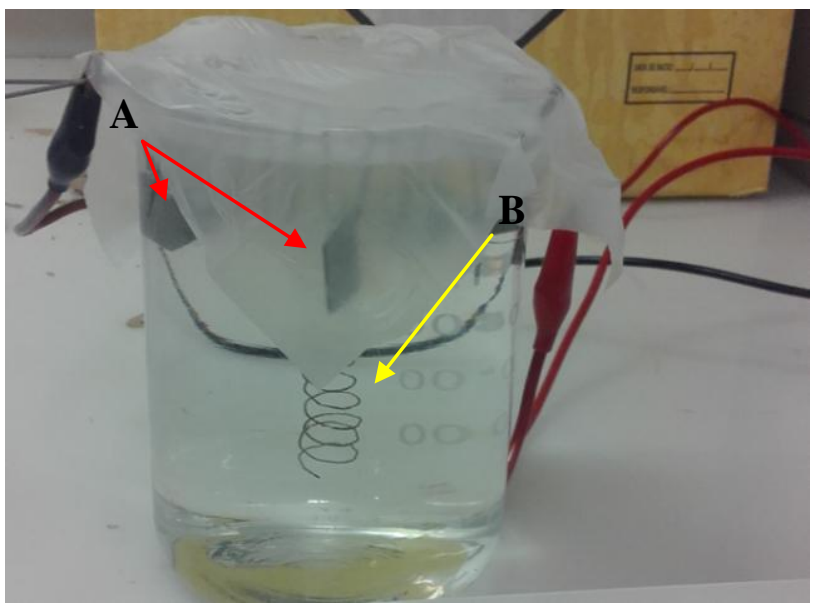

Figura 25. Arranjo experimental usado para fazer o carregamento com H no LNNano. Em A, conexão das amostras (indicadas pelas setas vermelhas) com a fonte de tensão; em B, conexão do contra-eletrodo de platina (indicado pela seta amarela) com a fonte de tensão.

Na Figura 25 são apresentados os seguintes componentes do sistema de carregamento:

- A: conector preto que conecta o eletrodo de trabalho à fonte de tensão. O eletrodo de trabalho é o suporte com as amostras (indicadas pelas setas vermelhas).O suporte das amostras era composto por aço inoxidável e tomou-se o cuidado de não cobri-lo com o eletrólito;

- B: conector vermelho que conecta o contra-eletrodo à fonte de tensão. $\mathrm{O}$ contra eletrodo é a platina, indicada pela seta amarela;

- Recobriu-se o béquer com parafilme para minimizar a evaporação do eletrólito durante o ensaio.

Como se pode observar pela Figura 25, o sistema é bastante simples, não permite o monitoramento da entrada de $\mathrm{H}$ e da saturação do material e não é desaearado. Na verdade, o único ensaio que permite monitorar a entrada de $\mathrm{H}$ é o de permeabilidade, pois mede a corrente elétrica oriunda da reação de oxidação do $\mathrm{H}$ atômico a $\mathrm{H}^{+}$.

Essas condições são completamente diferentes das utilizadas durante o ensaio de permeabilidade ao $\mathrm{H}$ - célula desaerada, injeção de $\mathrm{H}_{2} \mathrm{~S}$ e eletrólito composto pela solução A da NACE. O tempo para saturação com o método do $\mathrm{H}_{2} \mathrm{SO}_{4}$ e arsênico é desconhecido, enquanto que para o ensaio de permeabilidade sabe-se que a saturação por $\mathrm{H}$ destas amostras ocorre após 40-60 min de carregamento. Uma possibilidade era carregar as amostras com $\mathrm{H}$ no PMT-EPUSP, com método similar ao usado no ensaio de permeabilidade e, depois, levá- 
las ao LNNano, porém, o transporte das mesmas era complicado de se fazer. O hidrogênio difusível e, dependendo dos valores de $\mathrm{E}_{\mathrm{aT}}$ e $\mathrm{E}_{\mathrm{b}}, \mathrm{o}$ hidrogênio aprisionado por traps reversíveis escapam com facilidade do aço, mais especificamente da ferrita, à temperatura ambiente [75]. A imersão das amostras carregadas em nitrogênio líquido $\left(-196{ }^{\circ} \mathrm{C}\right)$ garante que os átomos de H se mantenham aprisionados em seu interior por até 14 dias [49] e, portanto, as amostras carregadas no PMT precisariam ser imediatamente congeladas em nitrogênio líquido e transportadas até o LNNano. A montagem de um sistema para isso era complexa e, então, preferiu-se fazer o carregamento no LNNano. Para compensar o uso do meio aerado, o tempo de carregamento com $\mathrm{H}$ das amostras no LNNano foi de $17 \mathrm{~h}$.

\subsubsection{Medidas de dessorção térmica}

Para impedir que, após o carregamento, os átomos de hidrogênio escapassem das amostras, as mesmas, primeiro, foram retiradas do eletrólito e imersas em banho de gelo; assim que a primeira amostra foi inserida no analisador e a medida de teor de hidrogênio teve início, as demais foram armazenadas em nitrogênio líquido.

Antes de se iniciar a medida de dessorção térmica, a amostra deve ser pesada em balança analítica, pois o valor da massa é um dos parâmetros necessários para programação da análise. Os procedimentos de secar a amostra (que estava no nitrogênio líquido ou no banho de gelo), pesagem, inserção no analisador de hidrogênio e programação da análise foram todos realizados em um total de 5 min para cada amostra, de modo que a quantidade de hidrogênio perdida fosse a menor possível e que esta perda fosse igual para todas elas.

É importante mencionar que o analisador deve ser calibrado e que cada calibração tem validade de $6 \mathrm{~h}$ - ou seja, em todos os dias de análise fez-se a calibração do equipamento antes de qualquer outra medição e, após 6 h de funcionamento, o mesmo era calibrado de novo.

$\mathrm{O}$ analisador de $\mathrm{H}$ é equipado com forno tubular infravermelho que aquece as amostras da temperatura ambiente até $400{ }^{\circ} \mathrm{C}$ em poucos segundos (em torno de $4 \mathrm{~s}$ ) para medir o hidrogênio difusível desprendido. O módulo que permite o uso de rampas de aquecimento e de detecção do hidrogênio liberado por diferentes tipos de traps não estava instalado na época em que as análises foram feitas e, por essa razão, conseguiu-se medir apenas a quantidade total de hidrogênio no interior de cada amostra. 


\section{Resultados}

\subsection{Caracterização Microestrutural por Microscopia Óptica e Eletrônica de Varredura}

\subsubsection{Análise de inclusões}

As Figuras 26 e 27 contêm micrografias representativas das seções longitudinais e transversais dos dois aços sem ataque, para comparação dos tipos de inclusões presentes nos mesmos.

As Figuras 26 (a) e (b) apresentam as superfícies das amostras longitudinal e transversal, respectivamente, do aço baixo $\mathrm{Mn}$, sem ataque e com aumento de $100 \mathrm{x}$.

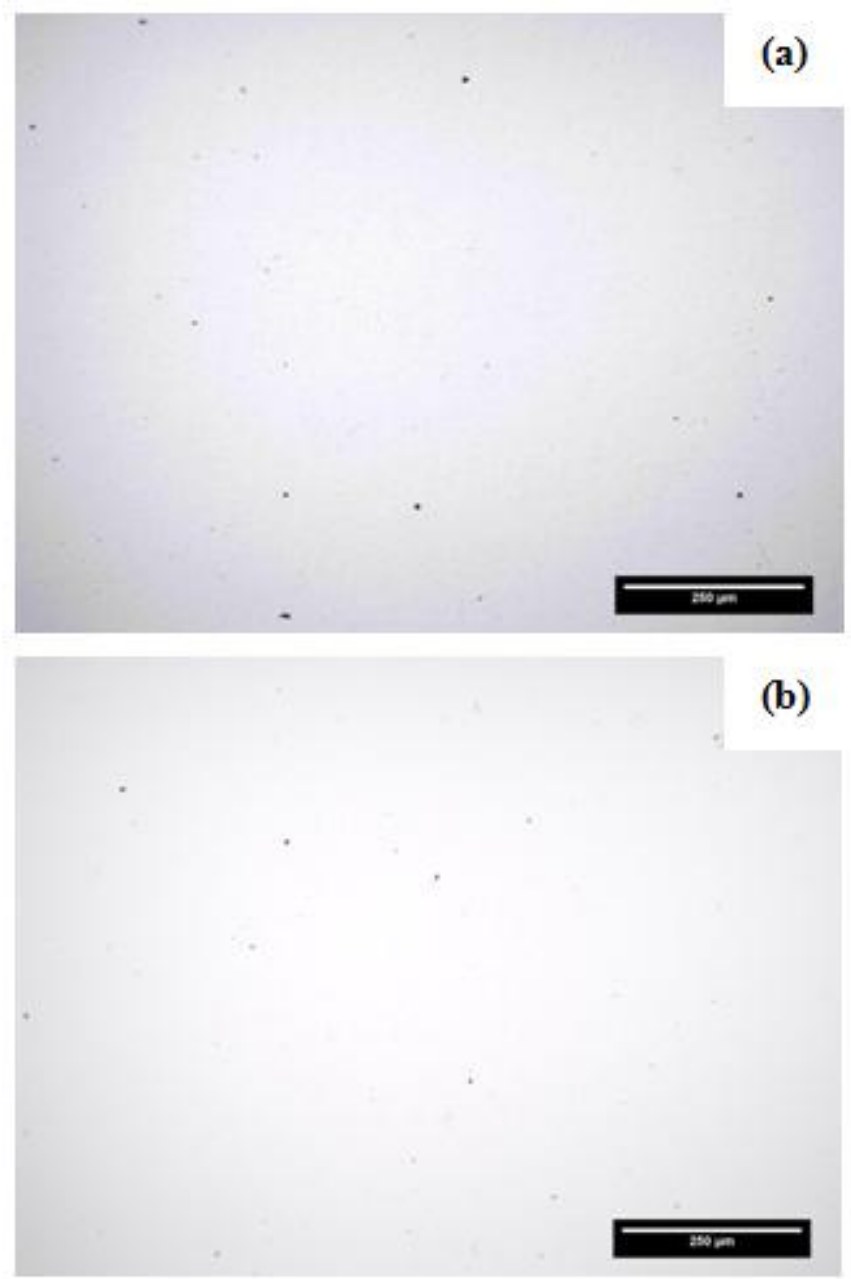

Figura 26. Inclusões presentes no aço baixo Mn. (a) Seção longitudinal da chapa e (b) seção transversal. Aumento: $100 \mathrm{x}$, sem ataque.

Pelas Figuras 26(a) e 26(b), observa-se que as inclusões presentes no aço com baixo Mn têm formatos globulares, encontram-se distribuídas de maneira homogênea e com 
dispersão aleatória pela superfície e que, qualitativamente, possuem pequenas dimensões. Ainda, de acordo com a classificação proposta pela norma ASTM E45-13 [84], estas inclusões podem ser classificadas como tipo D2, da série fina. Não se nota diferença significativa entre as duas seções apenas com as imagens obtidas por microscópio ótico, sendo necessário um estudo mais detalhado com o uso do microscópio eletrônico de varredura e que será apresentado mais adiante no texto.

As inclusões nas amostras do aço alto Mn apresentaram morfologias e distribuições mais heterogêneas e, por isso, na Figura 27 é apresentado um número maior de micrografias do que na Figura 26. As Figuras 27 (a), (b) e (c) foram retiradas de regiões equivalentes às 3 (canto superior direito), 5 (centro) e 9 (canto inferior direito) indicadas pela Figura 21, da seção longitudinal da chapa de aço alto Mn.
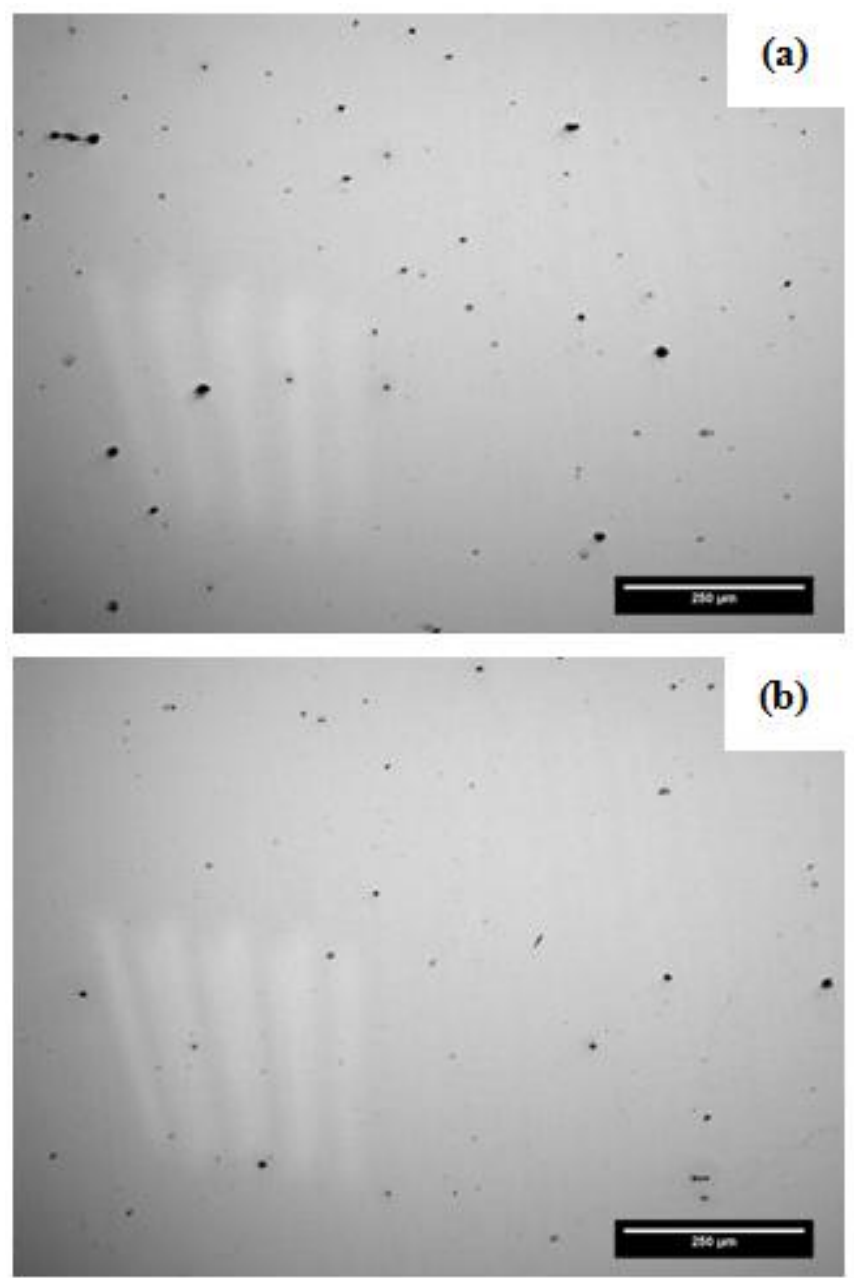

Figura 27. Inclusões presentes no aço alto Mn, na seção longitudinal. (a) Região superior direita da amostra, (b) centro da amostra e (c) região inferior direita. Aumento: 100 x, sem ataque. 


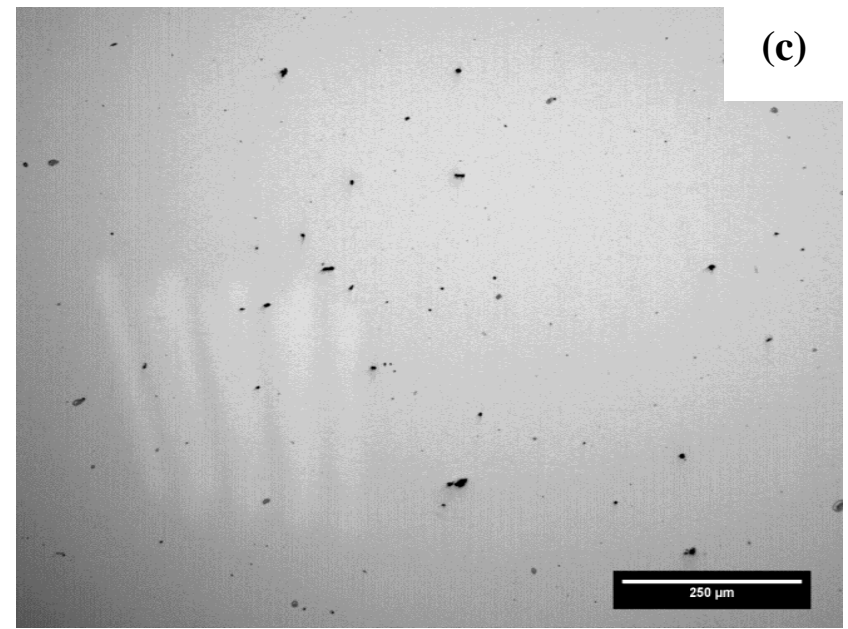

Figura 27. (Continuação) Inclusões presentes no aço alto Mn, na seção longitudinal. (a) Região superior direita da amostra, (b) centro da amostra e (c) região inferior direita. Aumento: 100 x, sem ataque.

As Figuras 27 (d), (e) e (f) apresentam as micrografias da seção transversal da chapa de aço com alto Mn e correspondem, respectivamente, às regiões 2 (centro da faixa superior), 5 (centro) e 7 (canto inferior esquerdo) da Figura 21.



Figura 27 (Continuação). Inclusões presentes no aço alto Mn, na seção transversal. (d) Região superior central da amostra, (e) centro da amostra e (f) região inferior esquerda. Aumento: 100 x, sem ataque. 

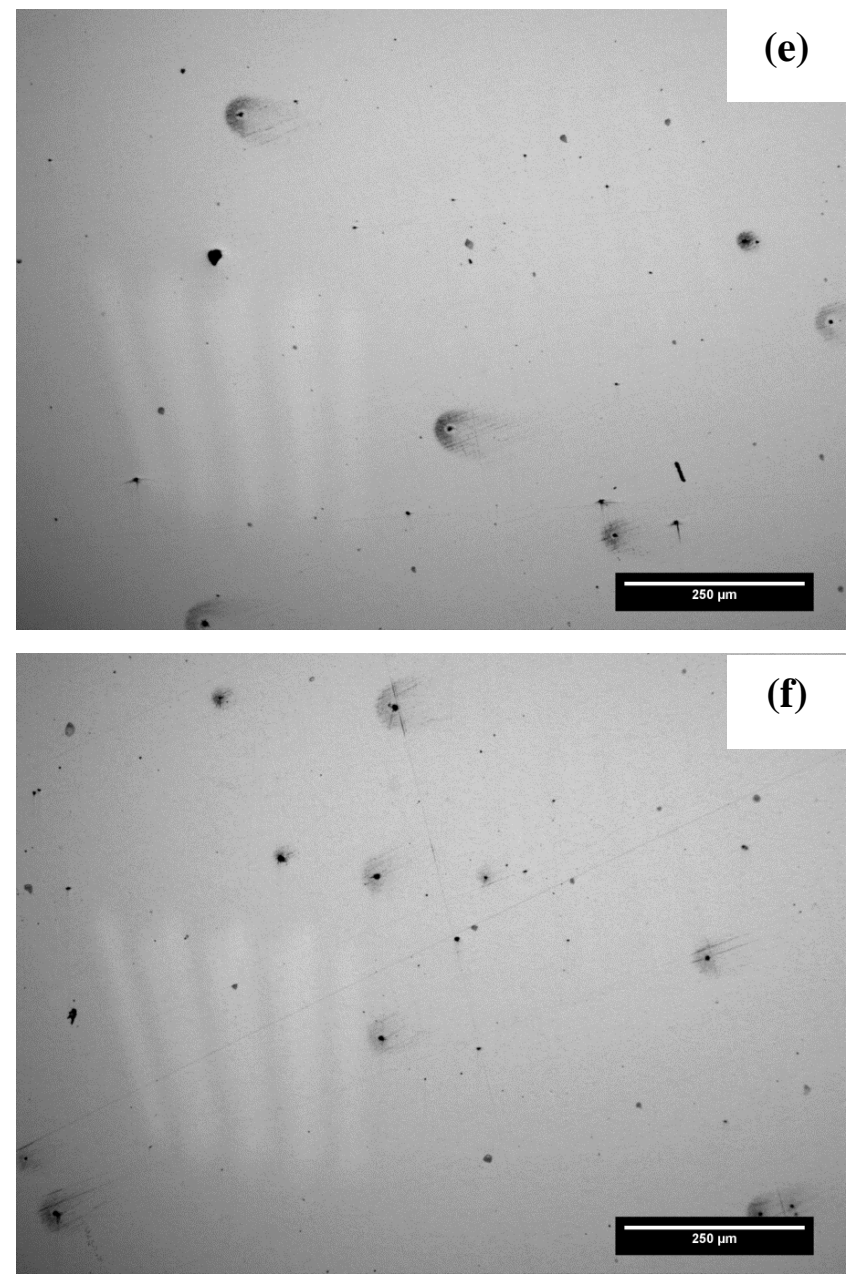

Figura 27(Continuação). Inclusões presentes no aço alto Mn, na seção transversal. (d) Região superior central da amostra, (e) centro da amostra e (f) região inferior esquerda. Aumento: 100 x, sem ataque.

Através das micrografias observa-se que as inclusões no aço com alto Mn possuem formatos mais variados do que as presentes no aço baixo $\mathrm{Mn}$ : algumas são levemente alongadas, outras têm forma mais próxima da globular. Ainda, estas inclusões são classificadas como D3 da série fina, de acordo com a norma ASTM E45-13 [81]. Os tamanhos das inclusões, qualitativamente, variam entre si, a sua dispersão é aleatória ao longo da espessura e a sua distribuição é heterogênea - algumas regiões se mostraram mais ricas em inclusões do que outras. Qualitativamente, as inclusões presentes no aço alto Mn apresentam maiores dimensões do que as do aço baixo $\mathrm{Mn}$.

Análises mais detalhadas das morfologias das inclusões e estimativas de suas composições químicas foram realizadas através das técnicas de microscopia eletrônica de varredura e de espectroscopia de energia dispersiva. As Figuras 28, 29 e 30 apresentam micrografias de elétrons retroespalhados do aço baixo Mn, junto das análises químicas feitas por EDS. A micrografia da Figura 28 foi obtida de amostra longitudinal do aço baixo Mn. 

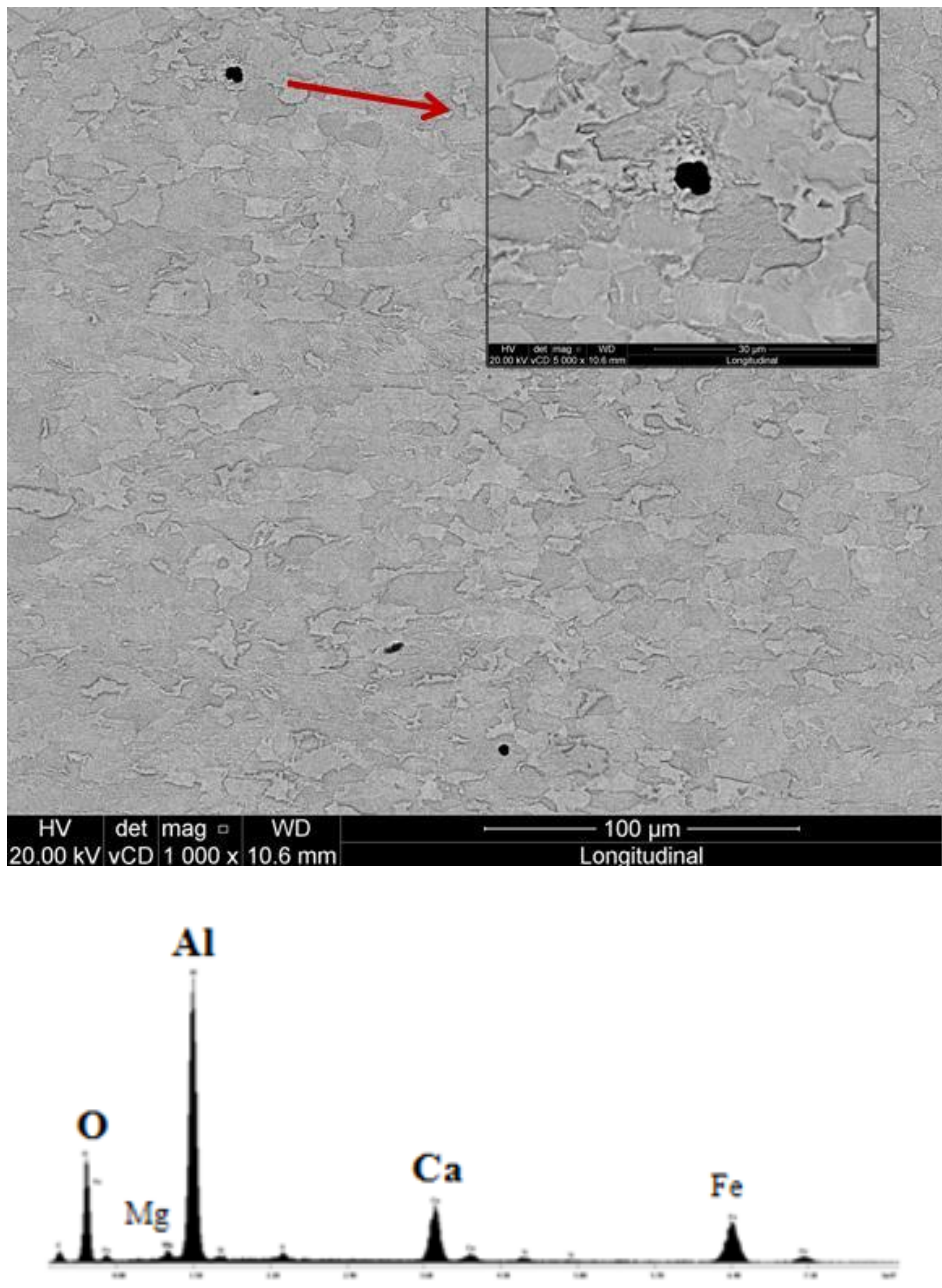

Figura 28. Micrografia de elétrons retroespalhados da superfície longitudinal ao sentido de laminação da chapa de aço baixo Mn; aumento de 1000 x. Destaque: inclusão com aumento de 5000 x. Abaixo, composição química da inclusão mostrada em destaque. Ataque: Nital $2 \%$.

Apesar da maior parte das inclusões observadas no aço baixo Mn possuírem forma arredondada, foi possível encontrar exceções. A Figura 29 a seguir, obtida a partir da superfície transversal ao sentido de laminação, mostra um caso de inclusão alongada. 



Figura 29. Micrografia de elétrons retroespalhados da superfície transversal ao sentido de laminação da chapa de aço baixo Mn; aumento de 5000 x. Abaixo, composição química da inclusão no centro da imagem. Ataque: Nital $2 \%$. 

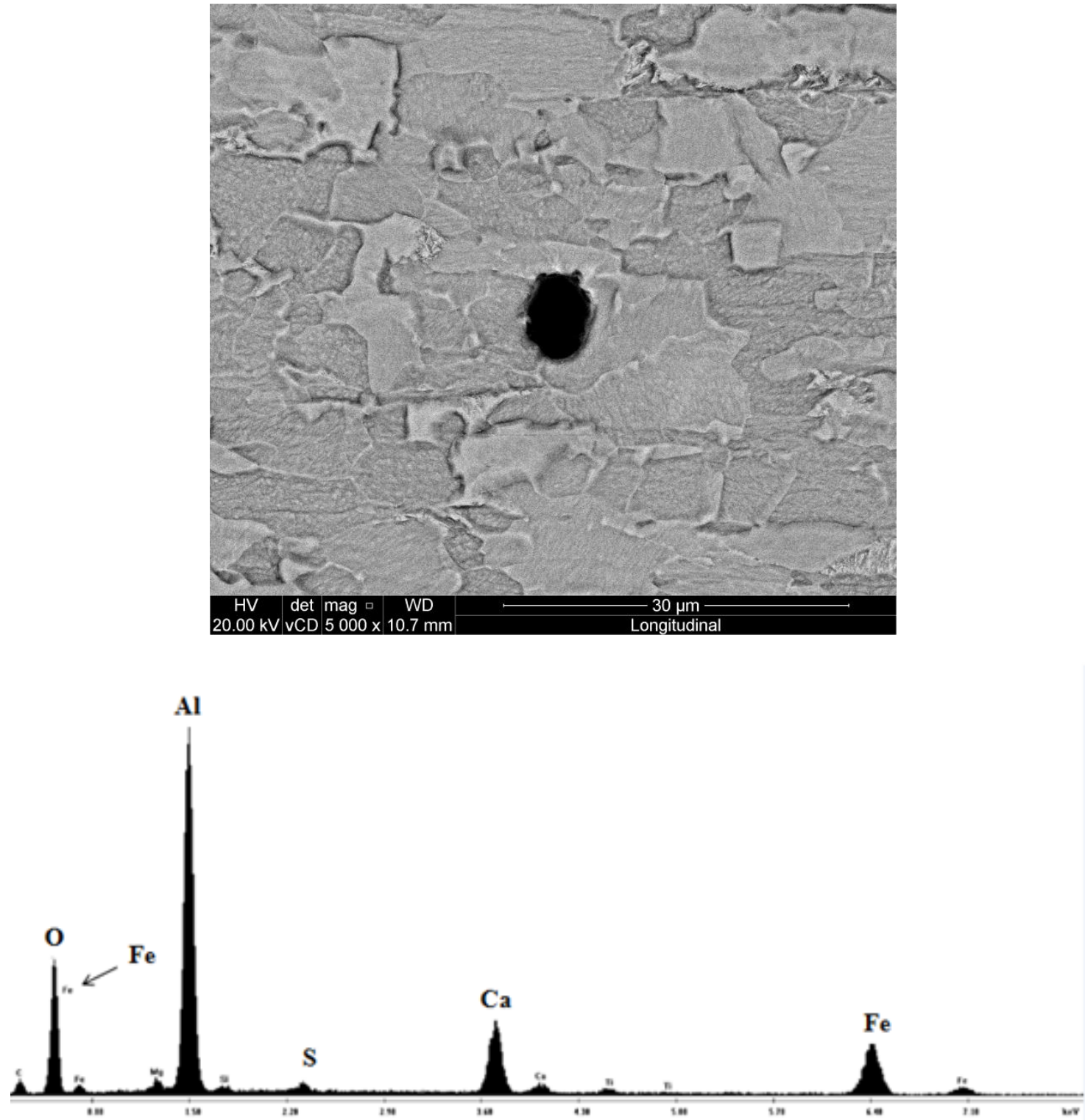

Figura 30. Micrografia de elétrons retroespalhados da superfície longitudinal ao sentido de laminação da chapa de aço baixo Mn; aumento de 5000 x. Ataque: Nital 2\%. Abaixo, composição química da inclusão no centro da imagem.

As imagens de MEV mostraram com mais clareza o formato arredondado das inclusões. Como se pode observar pelas análises químicas feitas com EDS, as inclusões presentes no aço baixo $\mathrm{Mn}$ são compostas, principalmente, por $\mathrm{Al}, \mathrm{Ca}$ e $\mathrm{O}$, com baixos teores de S.

A seguir, são apresentadas as micrografias de elétrons restroespalhados para o aço alto Mn, junto de suas respectivas análises químicas. Primeiro, na Figura 31, têm-se as imagens para a seção longitudinal ao sentido de laminação. Devido a maior diversidade de formatos encontrados nas inclusões deste aço, assim como foi feito para as micrografias ópticas, será 
apresentado um número maior de micrografias eletrônicas para ele, em comparação com o baixo Mn.
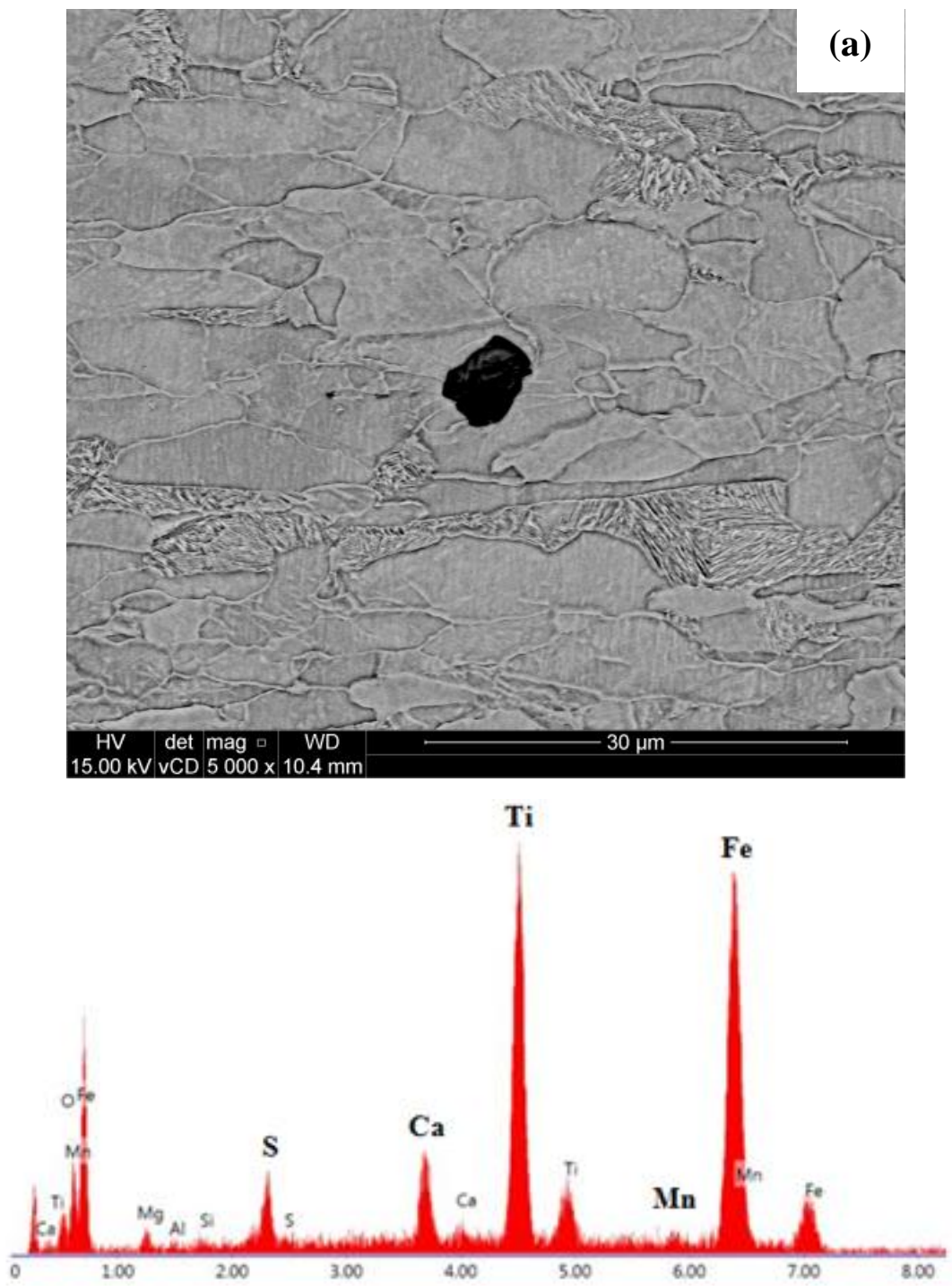

Figura 31(a). Micrografia de elétrons retroespalhados da superfície longitudinal ao sentido de laminação da chapa de aço alto Mn; aumento de 5000 x. Ataque: Nital 2\%. Abaixo, composição química da inclusão no centro da imagem. 

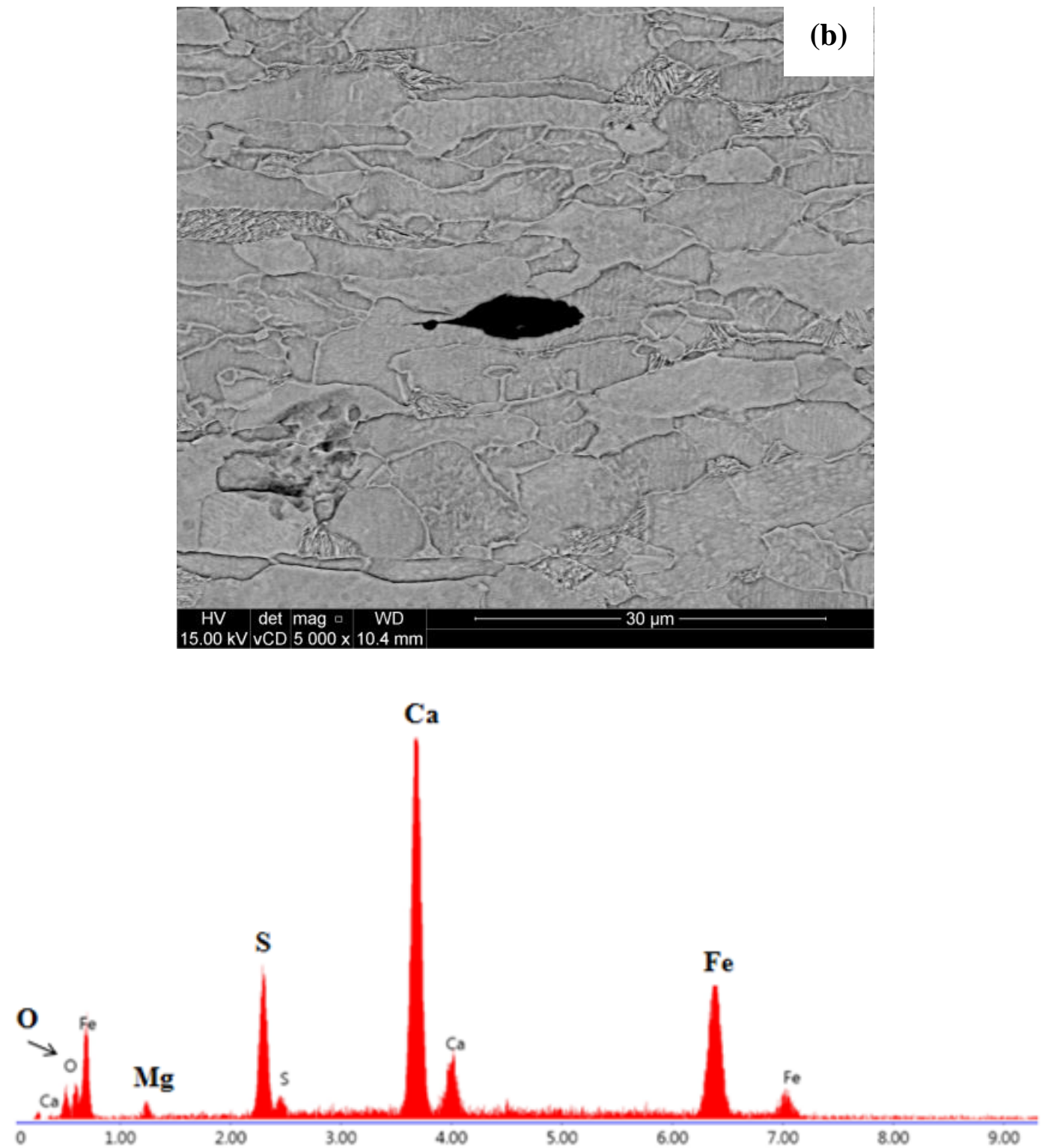

Figura 31(b). Micrografia de elétrons retroespalhados da superfície longitudinal ao sentido de laminação da chapa de aço alto Mn; aumento de 5000 x. Ataque: Nital 2\%. Abaixo, composição química da inclusão no centro da imagem. 

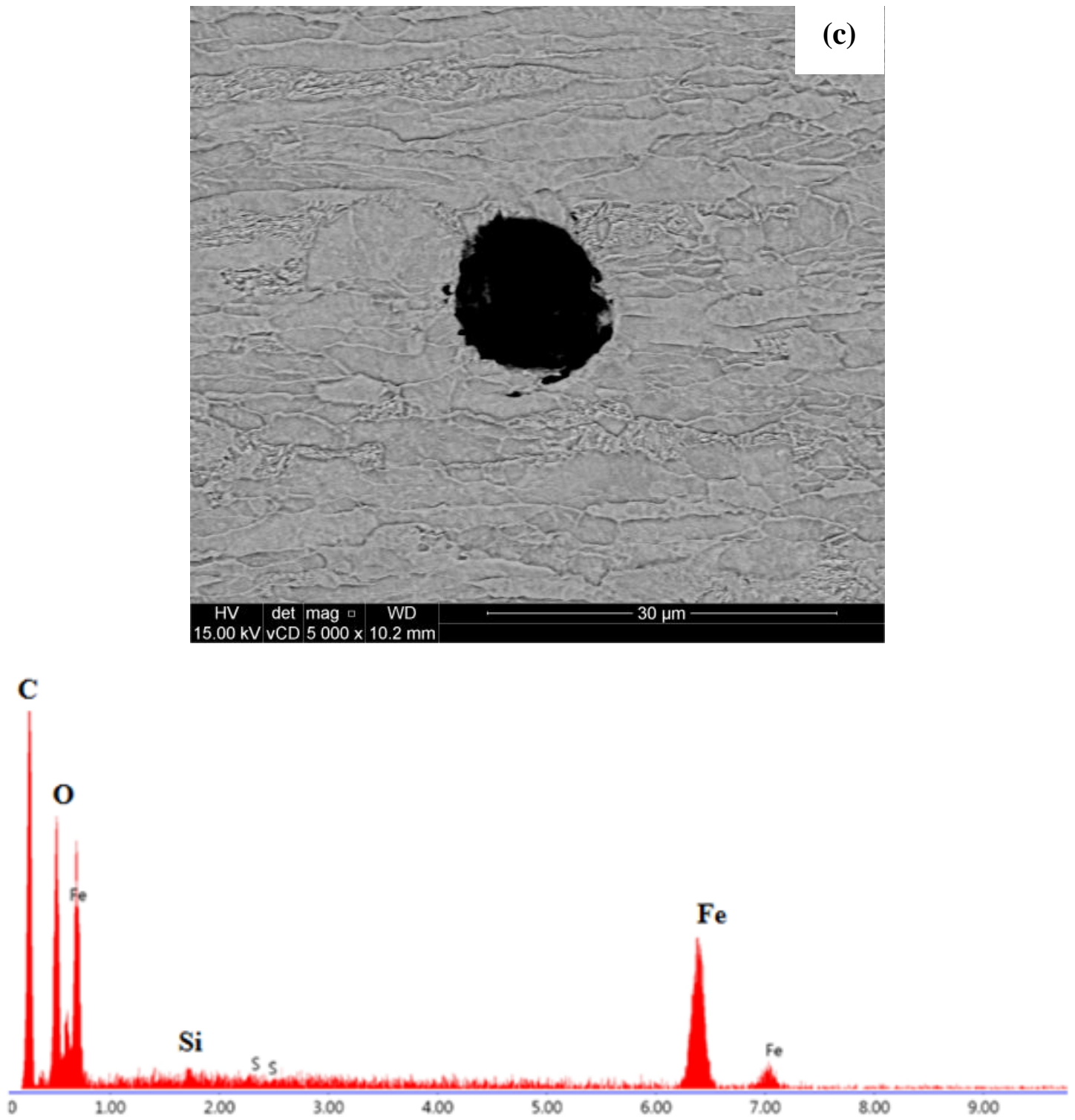

Figura 31(c). Micrografia de elétrons retroespalhados da superfície longitudinal ao sentido de laminação da chapa de aço alto Mn; aumento de 5000 x. Ataque: Nital 2\%. Abaixo, composição química da inclusão no centro da imagem. 

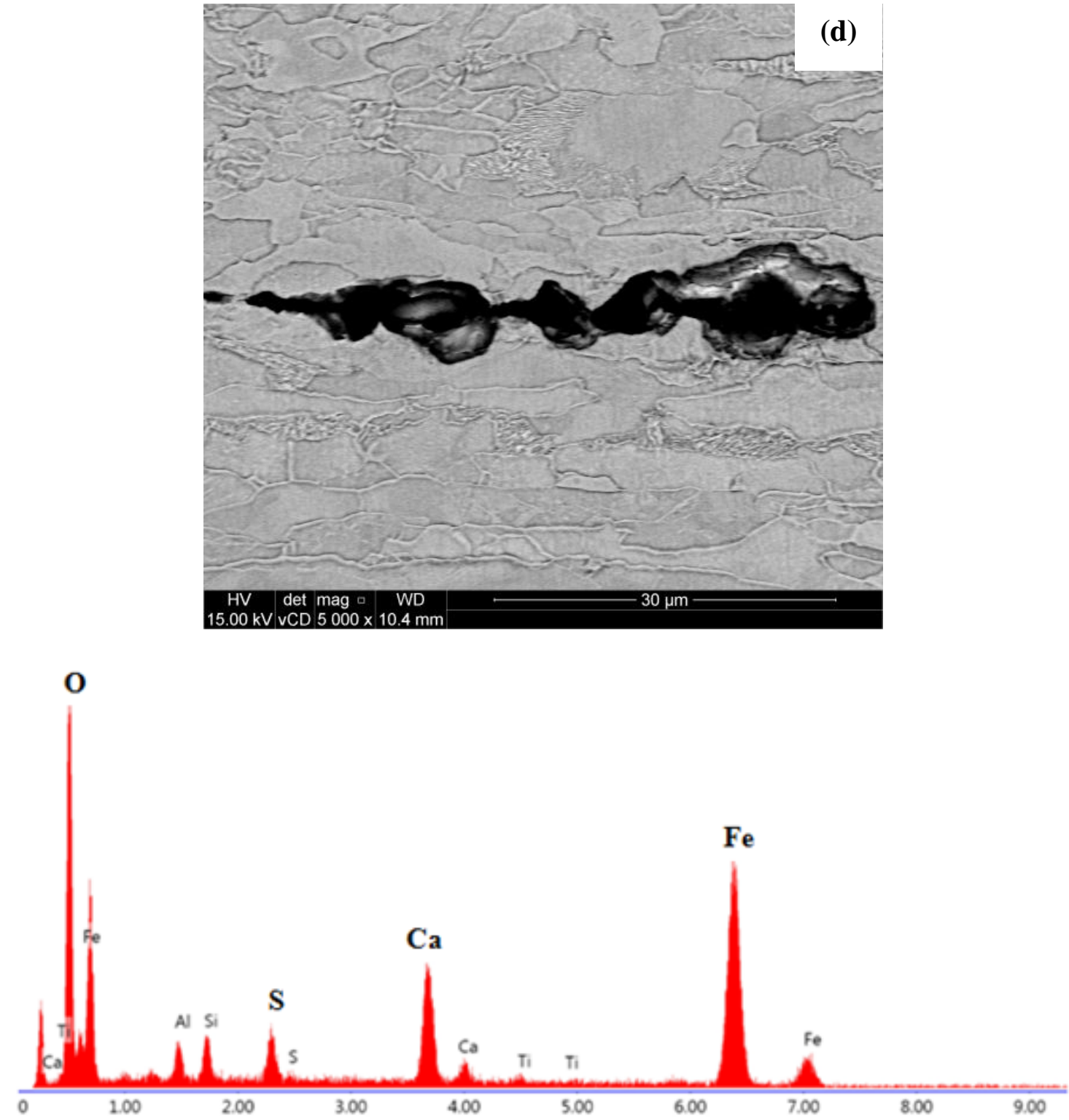

Figura 31(d). Micrografia de elétrons retroespalhados da superfície longitudinal ao sentido de laminação da chapa de aço alto Mn; aumento de 5000 x. Ataque: Nital 2\%. Abaixo, composição química da inclusão no centro da imagem.

Pelas micrografias ópticas foi possível observar que as inclusões presentes na seção longitudinal do aço alto Mn apresentavam diferenças morfológicas entre si mais pronunciadas do que as da seção transversal e, por meio das micrografias de elétrons retroespalhados, isso pode ser confirmado. Qualitativamente, notou-se maior fração de inclusões alongadas na amostra longitudinal do que na transversal. Isso é um efeito da laminação - o processo é responsável pelo alongamento dos microconstituintes no sentido em que é realizado. Assim, na Figura 32 são apresentadas as micrografias de elétrons retroespalhados da superfície da amostra transversal de aço alto Mn. 

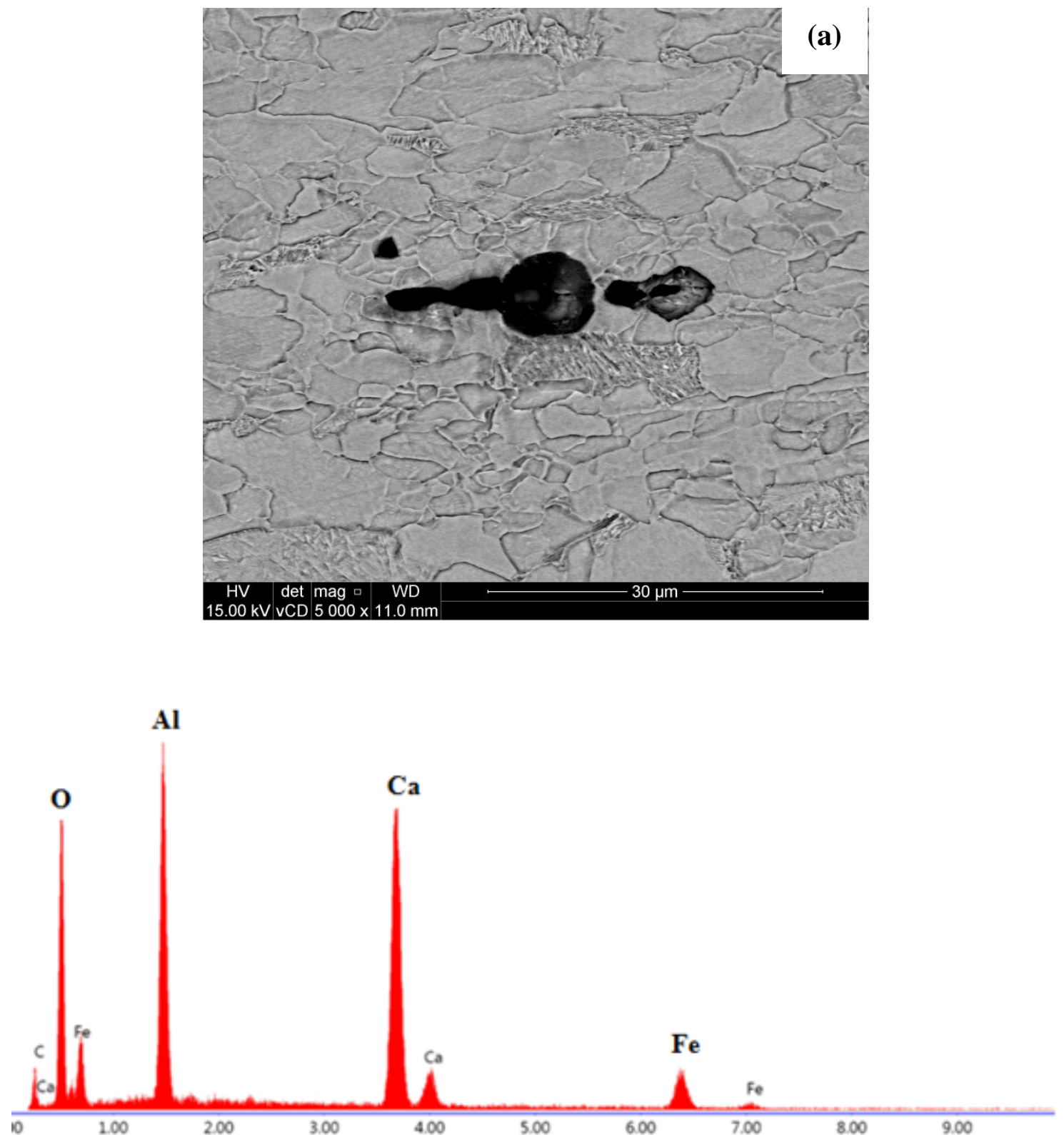

Figura 32(a). Micrografia de elétrons retroespalhados da superfície transversal ao sentido de laminação da chapa do aço alto Mn; aumento de 5000 x. Ataque: Nital 2\%. Abaixo, composição química da inclusão no centro da imagem. 

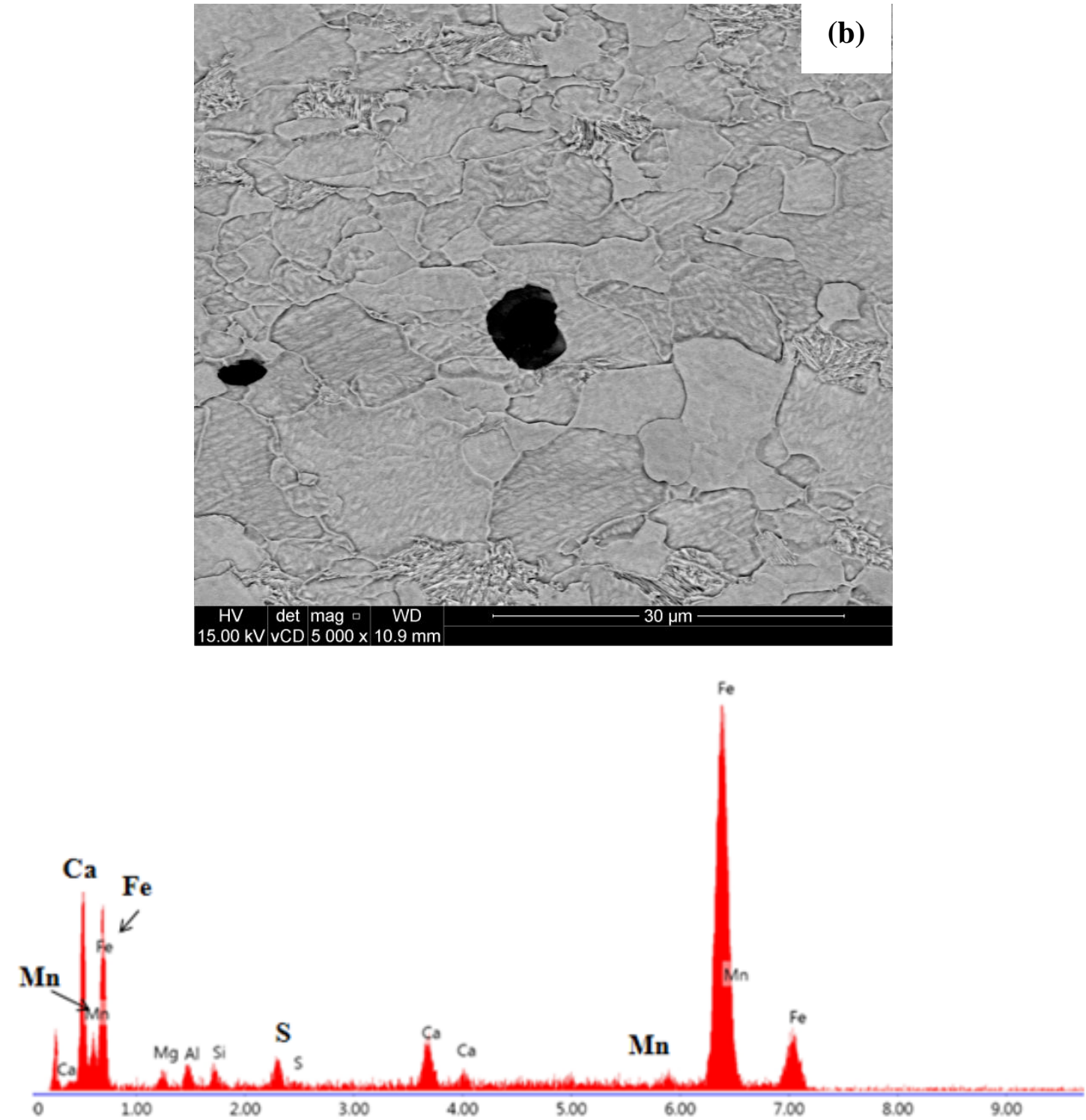

Figura 32(b). Micrografia de elétrons retroespalhados da superfície transversal ao sentido de laminação da chapa de aço alto Mn; aumento de 5000 x. Ataque: Nital 2\%. Abaixo, composição química da inclusão no centro da imagem. 

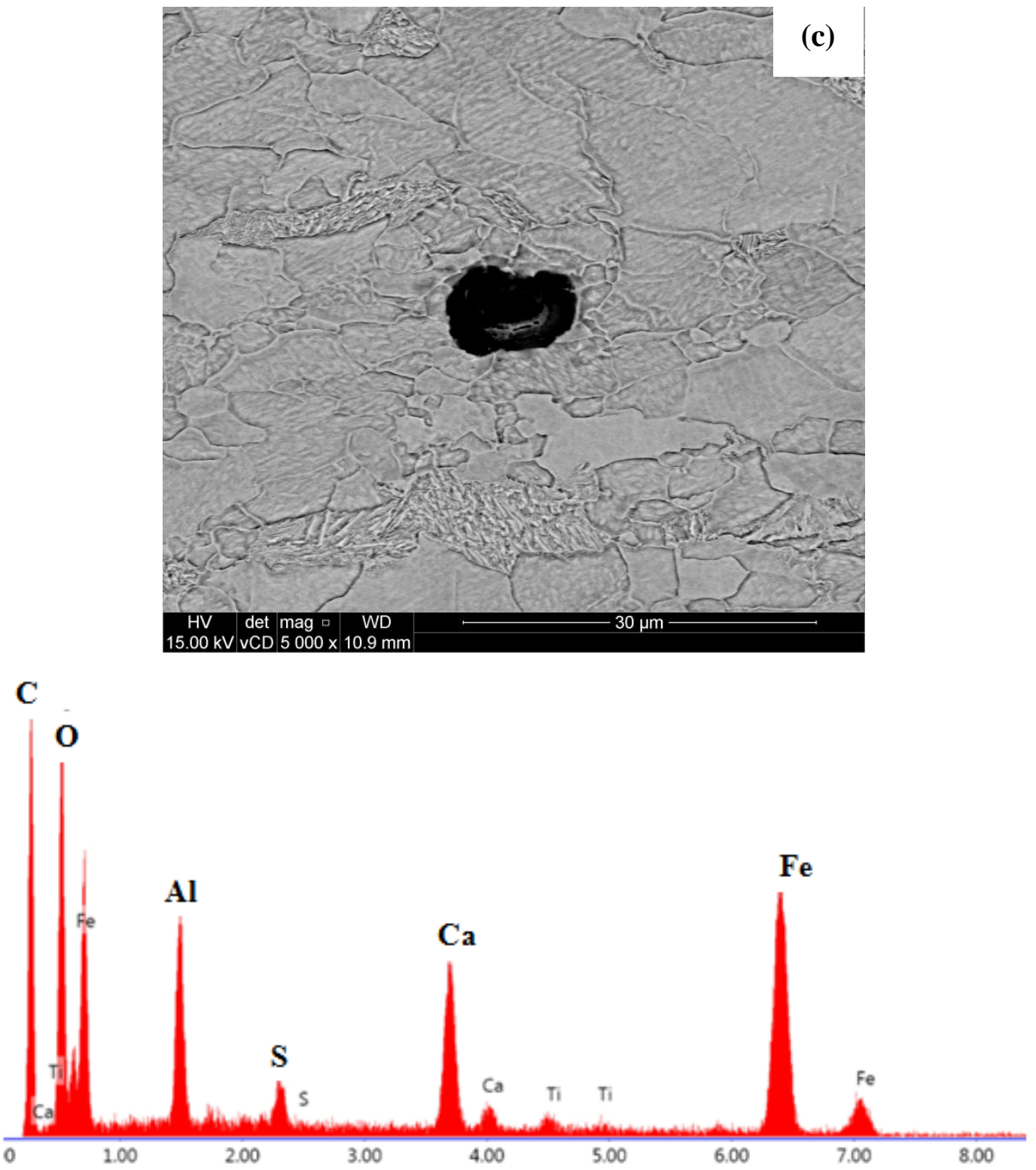

Figura 32(c). Micrografia de elétrons retroespalhados da superfície transversal ao sentido de laminação da chapa de aço alto Mn; aumento de 5000 x. Ataque: Nital 2\%. Abaixo, composição química da inclusão no centro da imagem.

A composição química das inclusões do aço com alto Mn é, de um modo geral, diferente das do aço com baixo Mn. Elementos como o Ti e o Mn aparecem com frequência considerável nas análises químicas das inclusões do aço alto $\mathrm{Mn}$; e, nesse caso de modo similar ao aço baixo $\mathrm{Mn}$, é possível ver que o tratamento com $\mathrm{Ca}$, para arredondar o formato das inclusões, também foi realizado. No entanto, dado à presença de inclusões alongadas no aço alto Mn, pode-se dizer que o tratamento com Ca não teve a mesma eficácia que o do aço baixo Mn. Algumas razões para explicar a menor eficácia desse tratamento no aço alto Mn são: (1) na época em que o aço alto Mn foi fabricado não se tinha a tecnologia avançada de 
hoje e (2) como o aço era destinado àaplicação em ambiente doce, esse tipo de controle das inclusões não tinha a mesma importância que se tem atualmente.

\subsubsection{Análise da microestrutura}

As amostras das duas chapas de aço foram observadas com microscópio ótico ao longo de sua espessura (Figura 20), em todos os aumentos disponíveis $(50 \mathrm{x}, 100 \mathrm{x}, 200 \mathrm{x}$, 500 x e 1000 x). Como o número de micrografias obtidas para cada seção foi consideravelmente grande, em torno de 30 micrografias por seção, serão apresentadas as mais representativas. A Figura 33 compara as microestruturas das três seções da chapa de aço baixo Mn.


Figura 33. Microestruturas das seções (a) longitudinal, (b) transversal e (c) topo do aço baixo Mn. Ataque: Nital $2 \%$. Aumento de $500 \mathrm{x}$. 


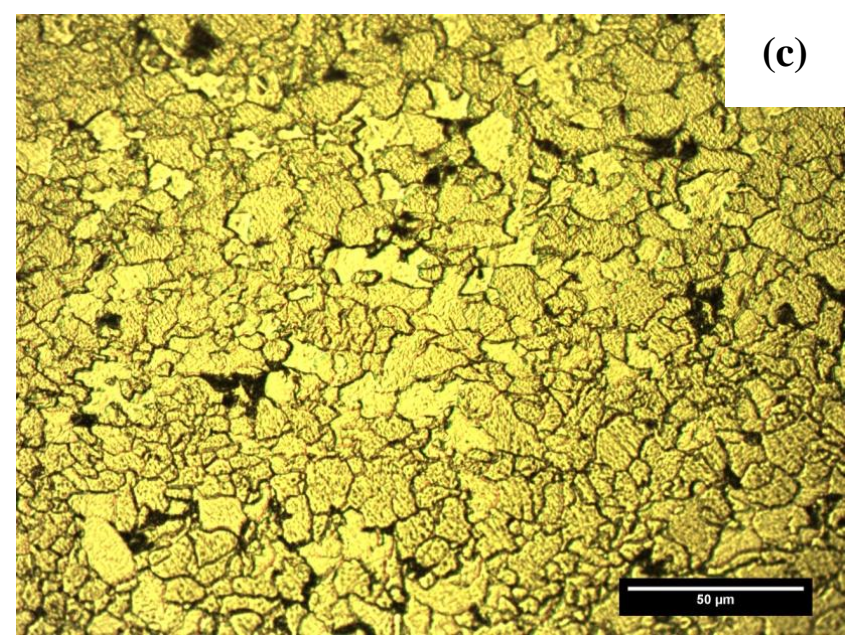

Figura 33. (Continuação) Microestruturas das seções (a) longitudinal, (b) transversal e (c) topo do aço baixo Mn. Ataque: Nital 2\%. Aumento de 500 x.

A microestrutura do material se mostrou homogênea, sem bandeamento, ao longo da espessura de cada amostra e com tamanho de grão bastante refinado - com aumentos inferiores a 500 x é difícil distinguir os grãos com clareza. As amostras longitudinal e transversal continham a espessura da chapa em sua extensão e, portanto, pode-se dizer que a homogeneidade mencionada foi observada por toda a espessura da chapa, em duas diferentes seções. Em princípio, quando se secciona uma placa de aço laminada, espera-se que a seção longitudinal apresente um alongamento significativo dos grãos, enquanto que a seção transversal tende a mostrar um arredondamento dos mesmos. No presente caso, nota-se uma diferença de alongamento dos grãos, entre as duas seções, pouco acentuada. Isso, junto do refinamento de grão, se deve ao processo de laminação controlada (TMCR) utilizado. É importante mencionar que esse grau de homogeneidade obtido nessa placa leva ao aumento da resistência aos danos provocados pelo hidrogênio. Pela Figura 33(c), nota-se que os grãos do topo da chapa mostram-se, também, arredondados e, de forma qualitativa,mais equiaxiais do que os das outras seções, devido ao tipo de vista proporcionado pelo corte nesta orientação.

A Figura 34 apresenta micrografias ópticas das seções longitudinal, transversal e do topo da chapa do aço alto Mn. Este aço, ao contrário do baixo Mn, possui microestrutura heterogênea e, por esta razão, micrografias obtidas em diferentes regiões das superfícies são exibidas. À esquerda, na Figura 34, são mostradas as regiões periféricas das amostras (bordas e $1 / 4$ de bordas) e, à direita, as regiões centrais. As imagens foram obtidas com aumento de 200 $\mathrm{x}$, permitindo que se tenha uma visão mais geral da microestrutura. 

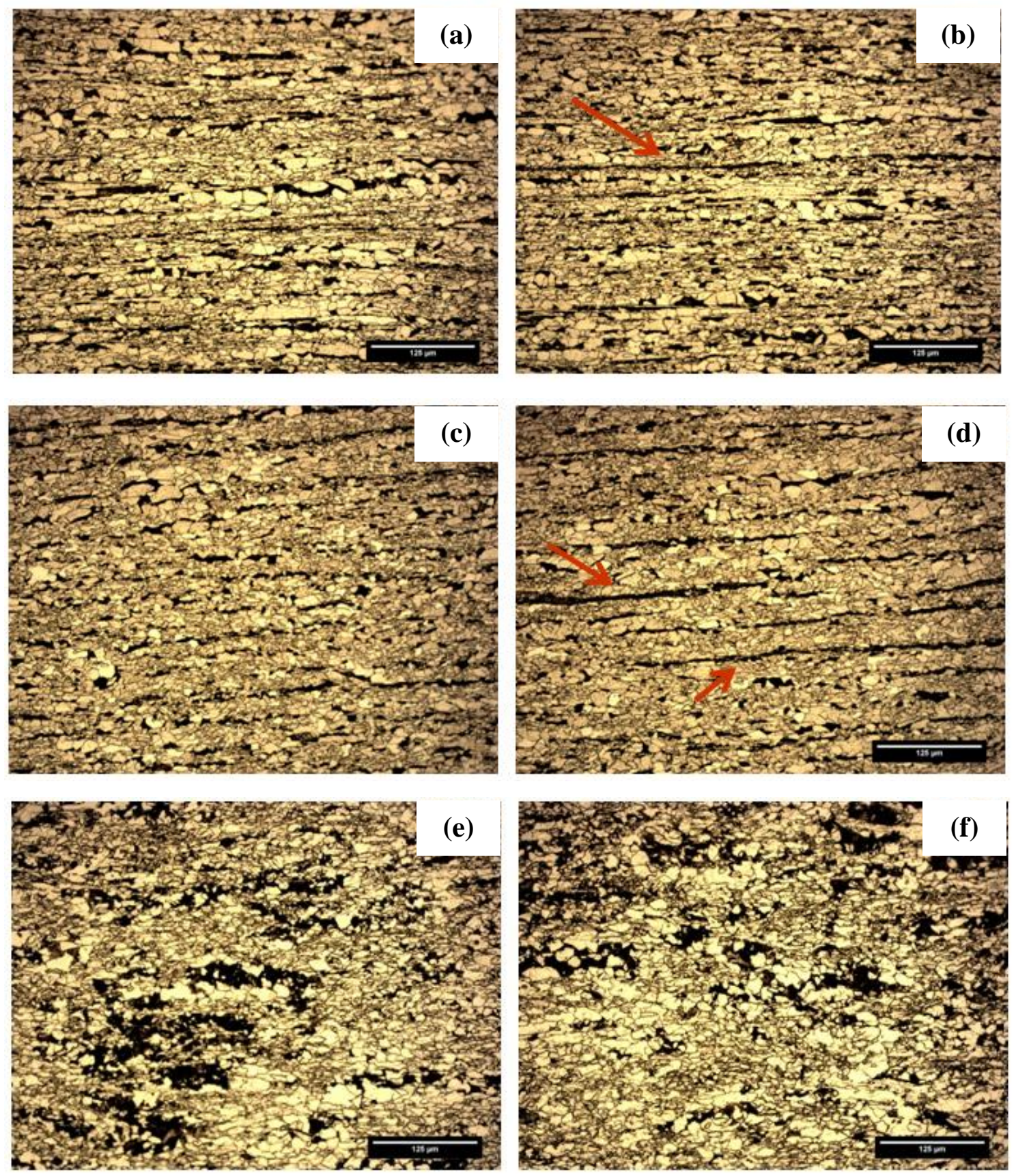

Figura 34. Micrografias ópticas das diferentes seções do aço alto Mn. (a) região periférica e (b) região central da superfície longitudinal; (c) região periférica e (d) região central da superfície transversal; (e) região periférica e (f) região central do topo da chapa. As setas vermelhas em (b) e (d) mostram bandas centrais compostas por microconstituintes diferentes dos demais componentes do aço, devido à segregação de elementos de liga. Ataque: Nital 2\%. Aumento: $200 \mathrm{x}$.

Nas Figuras 34(b) e 34(d) é possível observar a presença de "linhas", indicadas pelas setas vermelhas, escuras e contínuas (ou quase contínuas, na Figura 34(b)), ao longo da largura das micrografias, nas microestruturas das duas amostras, longitudinal e transversal, respectivamente. Tais linhas correspondem a bandas de microconstituintes diferentes dos encontrados nas outras regiões das amostras (Figuras 34(a) e 34(c)), formadas por conta de diferenças na composição química do material ao longo de sua espessura. As Figuras 34(e) e 
34(f), do topo da chapa, mostram placas de microconstituintes, em vez de bandas, devido ao tipo de vista proporcionado pelo corte.

A Figura 35 apresenta micrografias das regiões centrais das três amostras, em aumento de 500 x. Ao contrário do que foi observado para o aço baixo Mn, ao longo da espessura, o tamanho dos grãos e suas morfologias variam consideravelmente, além de se observar com clareza a presença de pelo menos dois microconstituintes - ferrita e perlita. Assim como para o aço baixo Mn, nota-se o alongamento dos grãos na seção longitudinal, por causa da laminação, e que os grãos da amostra do topo (Figuras 35(c) e 35(d)) da chapa também aparentam ser mais equiaxiais do que os da amostra tranversal (Figura 35(b)).
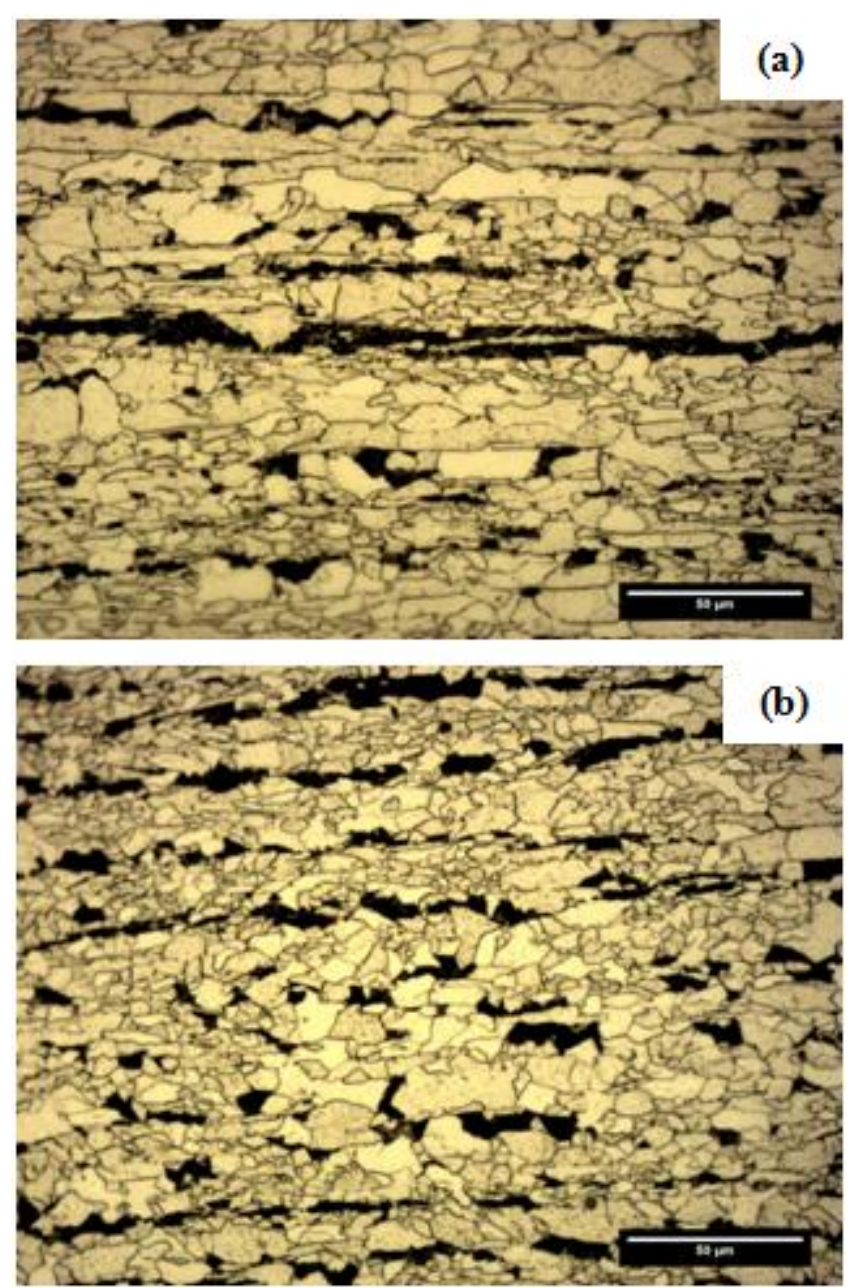

Figura 35. Micrografias ópticas das diferentes seções do aço alto Mn, em suas regiões centrais. (a) Longitudinal, (b) transversal, (c) e (d) topo. Ataque: Nital 2\%. Aumento: 500 x. 

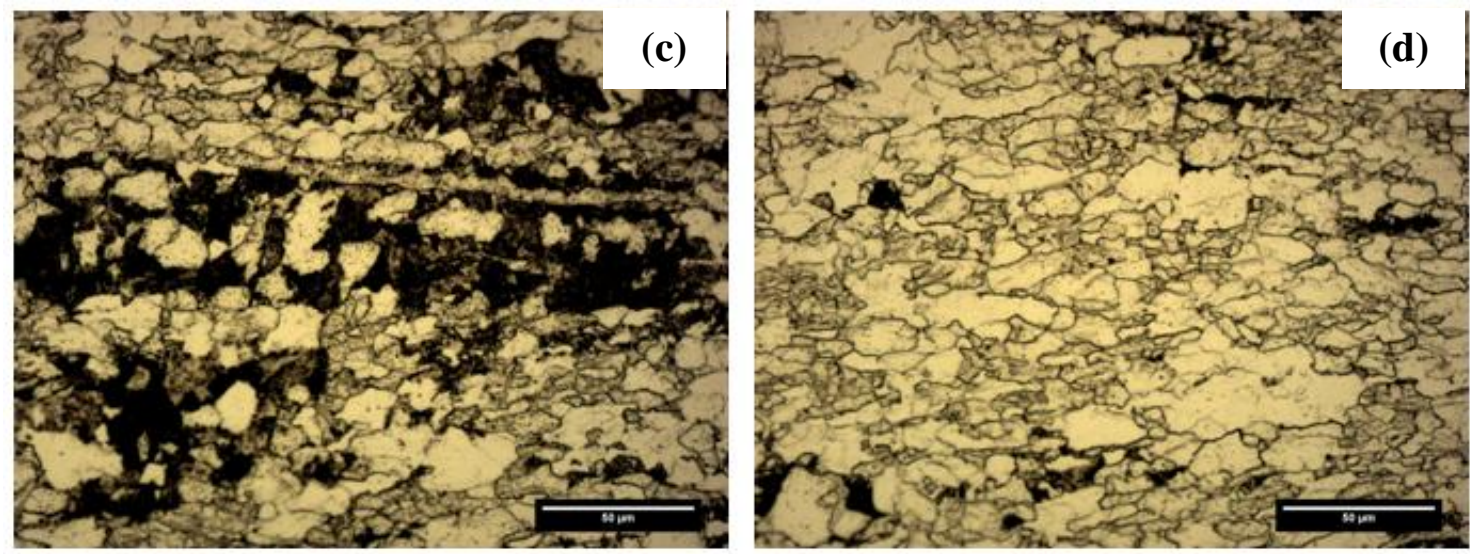

Figura 35. (Continuação) Micrografias ópticas das diferentes seções do aço alto Mn, em suas regiões centrais. (a) Longitudinal, (b) transversal, (c) e (d) topo. Ataque: Nital 2\%. Aumento: 500 x.

A Figura 36 compara as superfícies longitudinais e transversais das amostras dos dois aços, baixo e alto Mn, através de micrografias de elétrons secundários obtidas em baixos aumentos. As micrografias 36(b) e 36(d) mostram com clareza a microestrutura bandeada do aço com alto Mn.
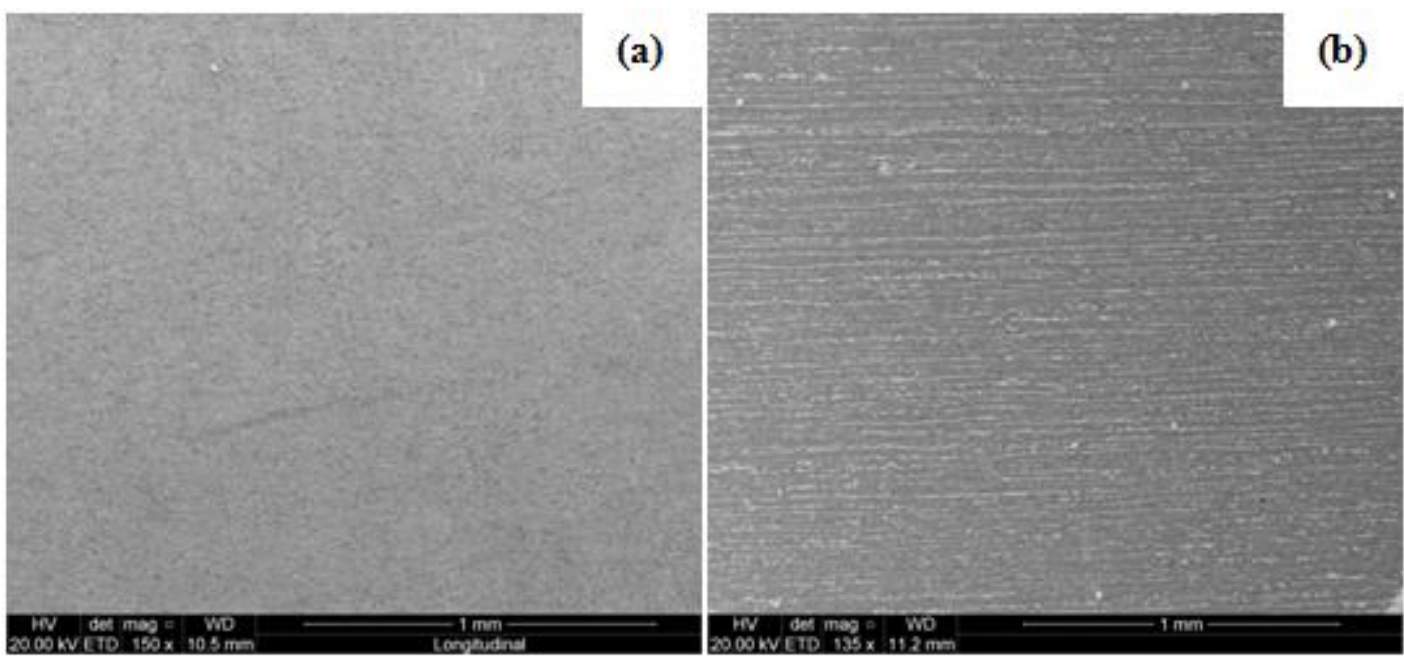

Figura 36. Micrografias de elétrons secundários dos dois aços estudados. (a) Seção longitudinal do aço baixo Mn, (b) seção longitudinal do aço alto Mn, (c) seção transversal do aço baixo Mn e (d) seção transversal do aço alto Mn. Aumentos de 150 x (a e c) e de 135 x (b e d). Ataque: Nital $2 \%$. 


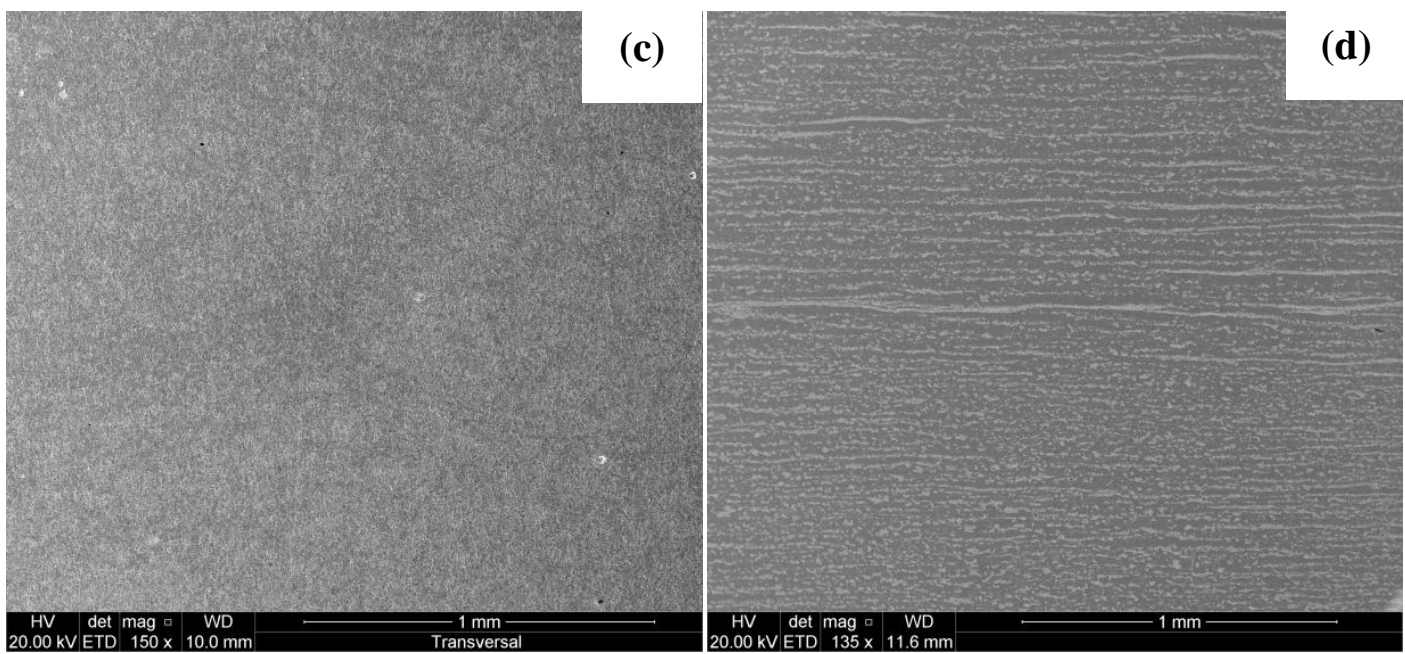

Figura 36. (Continuação) Micrografias de elétrons secundários dos dois aços estudados. (a) Seção longitudinal do aço baixo Mn, (b) seção longitudinal do aço alto Mn, (c) seção transversal do aço baixo Mn e (d) seção transversal do aço alto Mn. Aumentos de 150 x (a e c) e de 135 x (b e d). Ataque: Nital $2 \%$.

A Figura 37 apresenta micrografias de elétrons secundários das três seções do aço baixo $\mathrm{Mn}$, em aumento de $2500 \mathrm{x}$. A microestrutura deste aço é composta por grãos refinados de ferrita e de perlita (cor clara na imagem). Esta última aparece muito fina, degenerada e espalhada homogeneamente pela superfície. Não foram encontrados outros tipos de microconstituintes neste aço. O controle composicional da liga, junto das condições em que foram realizadas o processamento termomecânico de laminação controlada e de fabricação do aço (steelmaking) são responsáveis pela homogeneidade microestrutural da chapa.

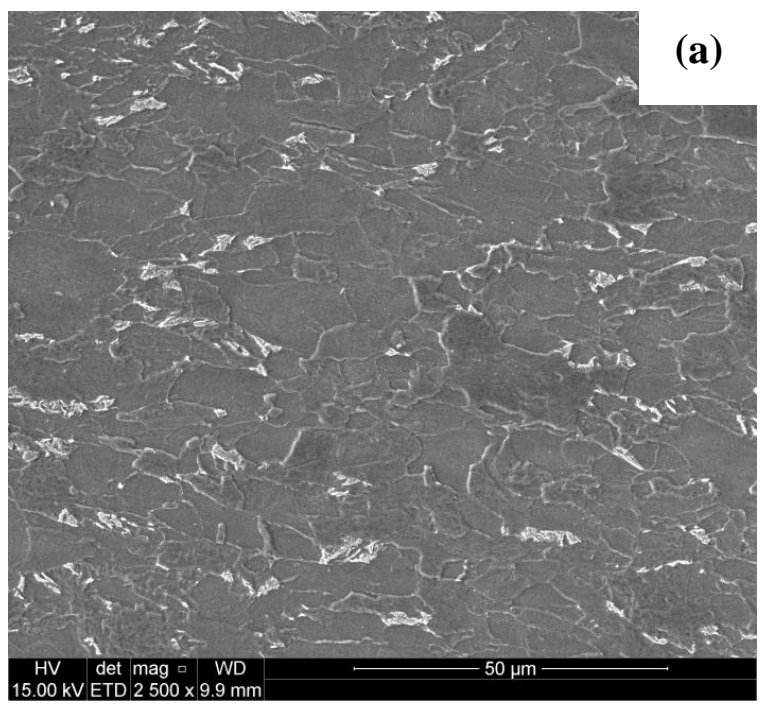

Figura 37. Micrografias de elétrons secundários do aço baixo Mn. (a) Seção longitudinal, (b) transversal e (c) topo. Aumento: 2500 x. Ataque: Nital 2\%. 

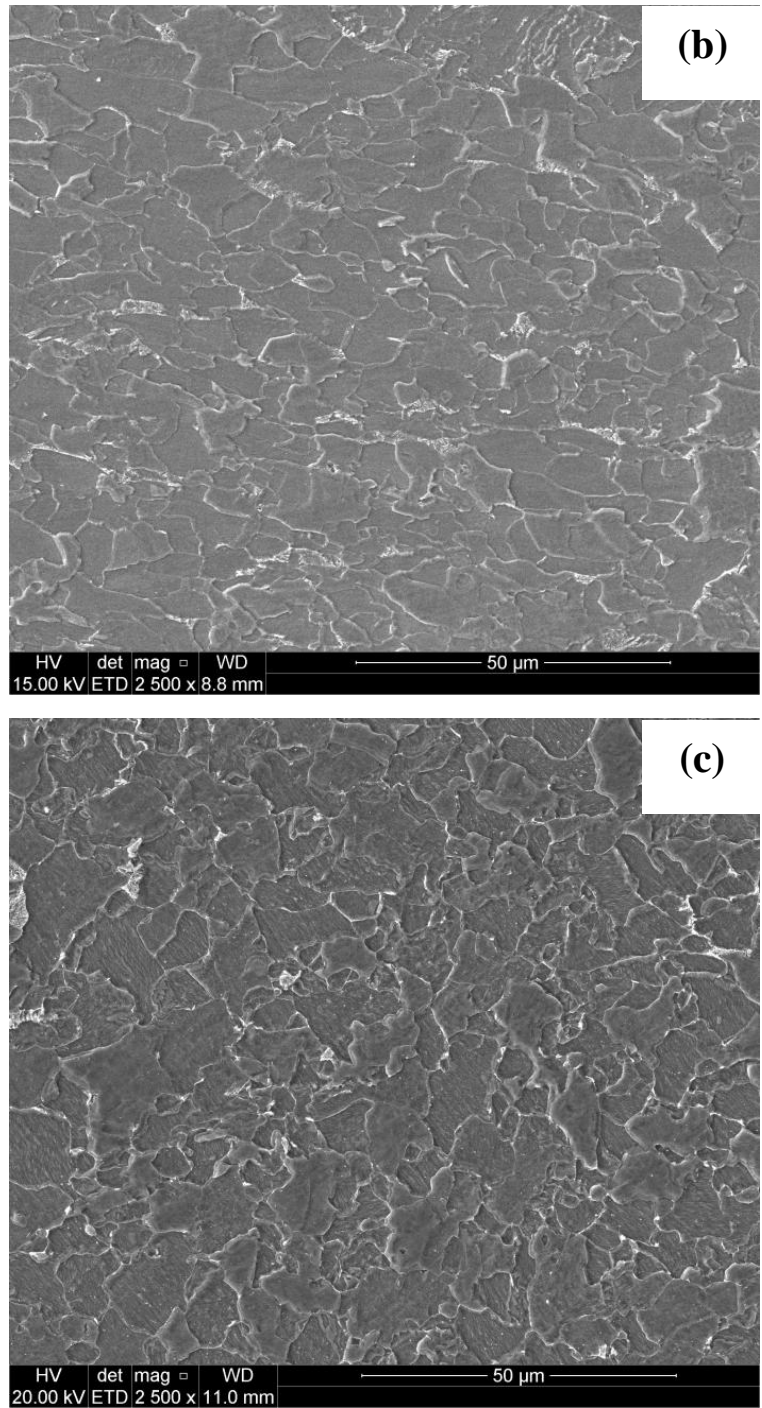

Figura 37. (Continuação) Micrografias de elétrons secundários do aço baixo Mn. (a) Seção longitudinal, (b) transversal e (c) topo. Aumento: 2500 x. Ataque: Nital 2\%.

Na Figura 38 é apresentada uma micrografia de elétrons secundários em aumento de $5000 \mathrm{x}$, para mostrar com mais detalhes as perlitas, indicadas pelas setas vermelhas, presentes no aço baixo Mn. 


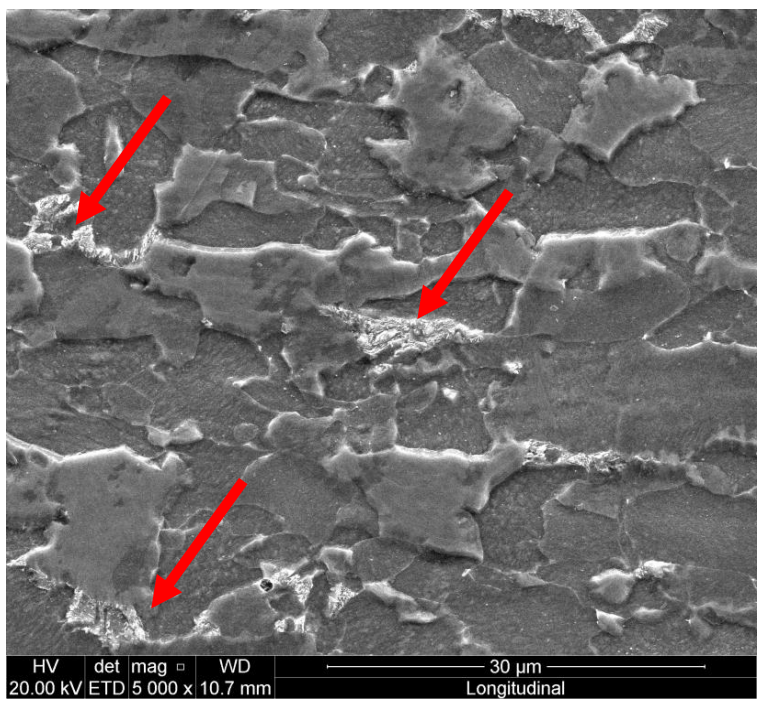

Figura 38. Micrografia de elétrons secundários da amostra longitudinal do aço baixo Mn. As setas em vermelho destacam algumas das perlitas presentes na microestrutura. Aumento: 5000 x. Ataque: Nital 2\%.

A Figura 39 contém imagens das seções longitudinal e transversal do aço alto Mn, em aumentos de $2500 \mathrm{x}$, mostrando as diferentes microestruturas das bandas das regiões centrais das amostras e das bordas.
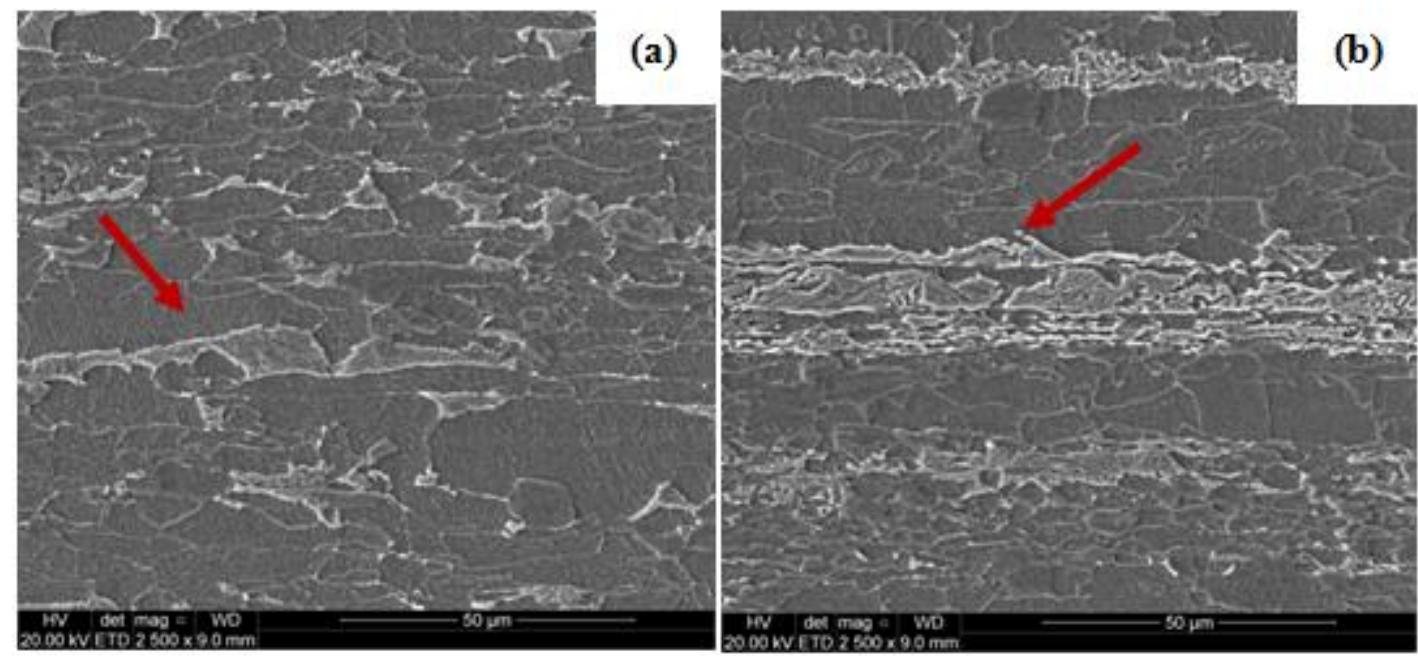

Figura 39. Micrografias de elétrons secundários do aço alto Mn. (a) região periférica da seção longitudinal, seta vermelha indica perlita, (b) região de banda central da seção longitudinal, seta vermelha indica a banda central, (c) região periférica da seção transversal, seta vermelha indica perlita e (d) região de banda central da seção transversal, seta vermelha indica banda central. 


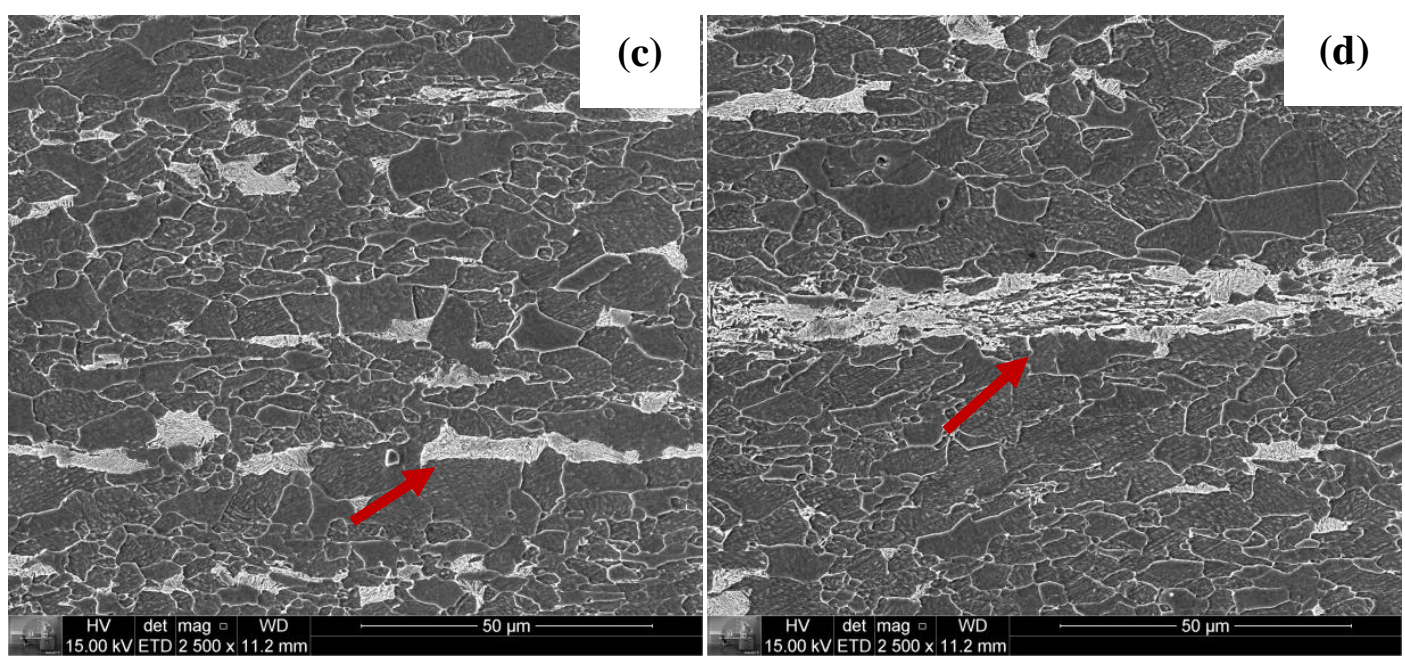

Figura 39. (Continuação) Micrografias de elétrons secundários do aço alto Mn. (a) região periférica da seção longitudinal, seta vermelha indica perlita, (b) região de banda central da seção longitudinal, seta vermelha indica a banda central, (c) região periférica da seção transversal, seta vermelha indica perlita e (d) região de banda central da seção transversal, seta vermelha indica banda central.

$\mathrm{O}$ aço alto $\mathrm{Mn}$, ao contrário do aço baixo $\mathrm{Mn}$, é formado por mais de dois microconstituintes. Pelas imagens da Figura 39, é possível ver que a microestrutura é composta por matriz ferrítica, perlita e, na região central, por alta concentração de agregados eutetóides. Estes agregados eutetóides foram caracterizados por Ogata [18] e, de acordo com o autor, são formados perlita, bainita e martensita, nitretos e carbonetos. Nas Figuras 39(a) e 39(c) são indicadas por setas vermelhas as perlitas, enquanto que nas Figuras 39(b) e 39(d), o destaque é dado para o aglomerado de componentes da linha central da chapa. Como não se podem ver as bandas a partir da seção do topo da chapa, uma micrografia desta amostra é apresentada na Figura 40.

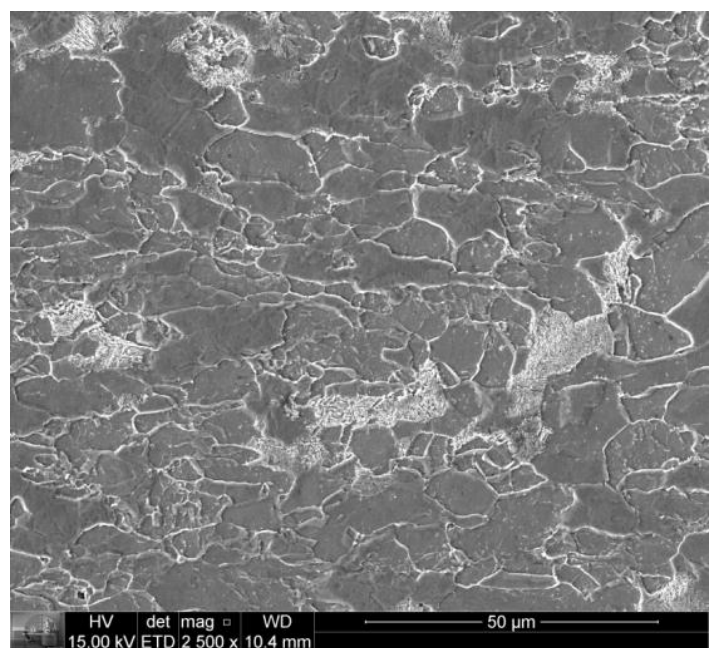

Figura 40. Micrografia de elétrons secundários de amostra retirada do topo da chapa do aço alto Mn. Aumento: 2500 x. Ataque: Nital 2\%. 
As estruturas perlíticas formadas no aço com alto Mn possuem, claramente, dimensões maiores do que as do aço baixo Mn, além da maior variação de tamanho de grãos ferríticos já mencionada. Também é possível notar maiores alongamento e alinhamento dos grãos de ferrita e das perlitas na amostra longitudinal, em comparação com as demais seções do mesmo aço, bem como com relação à seção longitudinal do aço baixo Mn.

As Figuras 41 e 42 mostram um exemplo de nitreto e outro de carboneto, respectivamente, encontrados no aço alto $\mathrm{Mn}$. O bandeamento microestrutural é originado da segregação de elementos de liga. A maior concentração de determinados elementos pode favorecer a formação de estruturas diferentes das observadas em outras regiões. Neste aço em questão, as regiões centrais das amostras têm teor mais elevado de Mn do que as demais. Análises químicas de diferentes áreas das amostras longitudinal e transversal foram realizadas para mostrar a variação do teor de Mn ao longo da espessura da chapa e são apresentadas, também, pelas Figuras 41 e 42.

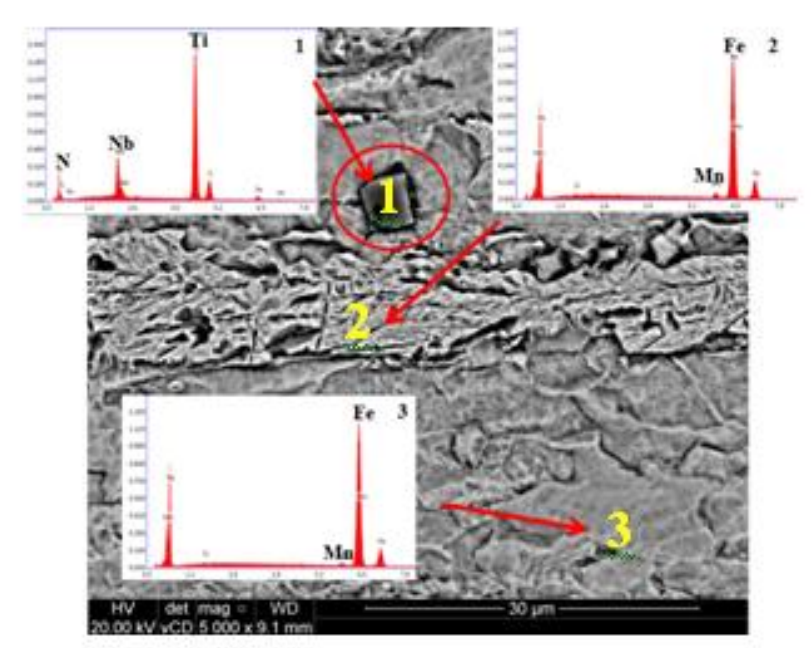

\begin{tabular}{|c|c|c|c|}
\hline \multicolumn{4}{|c|}{ Ponto l } \\
\hline Elemento & N & Nb & Ti \\
\hline \% Massa & 15,61 & 15,01 & 66,13 \\
\hline \multicolumn{4}{|c|}{ Área 2 } \\
\hline Elemento & Si & Mn & Fe \\
\hline \% Massa & 0,37 & 2,73 & $96,90 /$ \\
\hline \multicolumn{5}{|c|}{ Área 3 } \\
\hline Elemento & Si & Mn & Fe \\
\hline \% Massa & 0,28 & 1,60 & 98,13 \\
\hline
\end{tabular}

Figura 41. Micrografia de elétrons retroespalhados de amostra longitudinal do aço alto Mn, junto de espectros de EDS (detalhes na imagem) e tabela com os principais elementos encontrados na análise química. Aumento: 5000 x. Ataque: Nital 2\%.

Como se pode notar pelos dados da Figura 41, o microconstituinte em destaque corresponde a um nitreto rico em Ti, que contém, também, $\mathrm{Nb}$. O teor de $\mathrm{Mn}$ na banda microestrutural (Área 2) é mais elevado do que fora dela (Área 3), justificando as diferenças na microestrutura comentadas. 


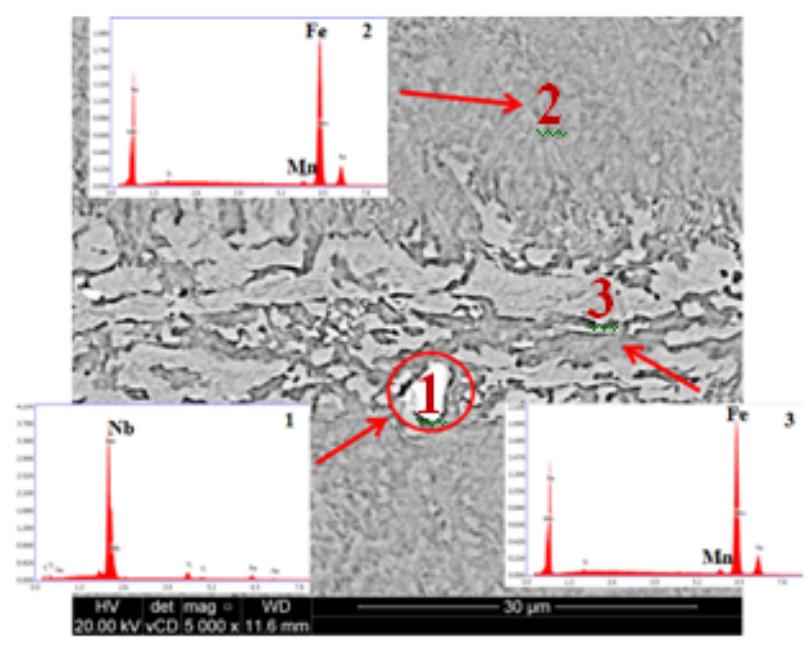

\begin{tabular}{|c|c|c|c|}
\hline \multicolumn{4}{|c|}{ Ponto l } \\
\hline Elemento & C & Nb & Ti \\
\hline \% Massa & 16,94 & 74,37 & 4,65 \\
\hline \multicolumn{4}{|c|}{ Área 2 } \\
\hline Elemento & Si & Mn & Fe \\
\hline \% Massa & 0,41 & 1,85 & 97,73 \\
\hline \multicolumn{4}{|c|}{ Área 3 } \\
\hline Elemento & Si & Mn & Fe \\
\hline \% Massa & 0,50 & 2,59 & 96,90 \\
\hline
\end{tabular}

Figura 42. Micrografia de elétrons retroespalhados de amostra transversal do aço alto Mn, junto de espectros de EDS (detalhes na imagem) e tabela com os principais elementos encontrados na análise química. Aumento: 5000 x. Ataque: Nital $2 \%$.

A Figura 42 mostra um carboneto de $\mathrm{Nb}$ (ponto 1) e também a variação do teor de $\mathrm{Mn}$ em função da espessura da chapa - no centro o teor de Mn é de 2,59\% em massa (área 3), enquanto que, fora dele, é de 1,85\% em massa (área 2). Mesmo com as medidas de EDS não sendo muito exatas, por conta da resolução deste tipo de equipamento, estes resultados, em conjunto com as imagens mostrando o bandeamento, ajudam a perceber a existência da segregação de Mn na linha central da chapa. No total, foram feitas 6 medidas de EDS de área em regiões bandeadas e não bandeadas, para cada tipo de amostra e todos os resultados foram similares aos apresentados.

\subsubsection{Metalografia Quantitativa}

\subsubsection{Fração Volumétrica de Perlita}

A Tabela 16 a seguir apresenta os valores de fração volumétrica média de perlita $\left(\mathrm{V}_{\mathrm{v}}\right.$ média) medidos para os dois aços, seus respectivos desvios padrão, e o total de perlitas contadas em todos os campos analisados, para cada seção. Lembrando que as medidas foram feitas com o analisador de imagens LAS 4,5 da Leica, em imagens de elétrons secundários com aumento de 2500 x. Aumentos menores, como de 500 x ou 200 x, não permitem a visualização clara das perlitas no aço baixo $\mathrm{Mn}$, pois as mesmas têm dimensões pequenas. A Figura 43 contém uma micrografia de cada seção em cada um dos aços, para efeito de ilustração do procedimento usado e de comparação com os valores mostrados pela Tabela 16. 
Tabela 16. Frações volumétricas médias de perlita $\left(\mathrm{V}_{\mathrm{v}}\right.$ perlita média), seus respectivos desvios padrão e o total de perlitas contadas para as seções longitudinal, transversal e topo dos dois aços.

\begin{tabular}{|c|c|c|c|}
\hline \multicolumn{4}{|c|}{ Aço Baixo Mn (0,5\% Mn) } \\
\hline & Longitudinal & Transversal & Topo \\
\hline Total de perlitas contadas & 1179 & 750 & 300 \\
\hline V $_{\text {v perlita média \% } \pm \text { desvio padrão }}$ & $5,9 \pm 0,6$ & $4,1 \pm 0,9$ & $4,6 \pm 2,1$ \\
\hline \multicolumn{4}{|c|}{ Aço Alto Mn (1,49\% Mn) } \\
\hline & Longitudinal & Transversal & Topo \\
\hline Total de Perlitas Contadas & 338 & 525 & 224 \\
\hline V $_{\text {v perlita média \% }} \pm$ desvio padrão & $11,1 \pm 2,1$ & $13,9 \pm 1,5$ & $15,9 \pm 7,5$ \\
\hline
\end{tabular}

Como era esperado, o aço com alto Mn apresenta maior fração volumétrica de perlita do que o aço baixo Mn. Os desvios padrões das medidas, no entanto, se mostraram bastante altos. Isso significa que um maior número de campos precisa ser analisado, para aumentar a precisão dos resultados - estes valores podem ser tomados, então, como uma estimativa da fração volumétrica de perlita nos dois aços. O desvio padrão da amostra Topo, do aço alto Mn, em especial, foi muito grande - cerca de $50 \%$ do valor médio. Esta seção foi a que apresentou maior heterogeneidade de distribuição das perlitas ao longo da superfície, ou seja, algumas regiões mostravam grandes aglomerações de perlita e outras continham pouquíssimas, como se pode observar pelas Figuras 35(c) e 35(d). Isso justifica o alto desvio padrão calculado. 


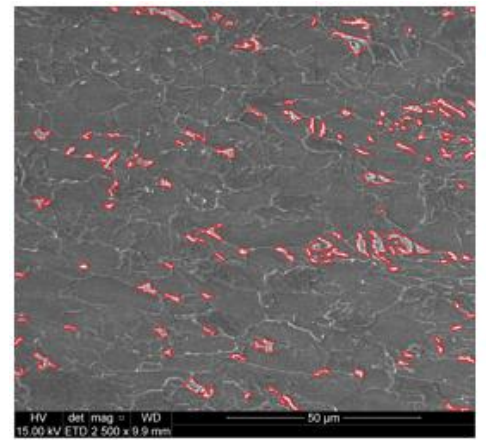

(a)



(d)

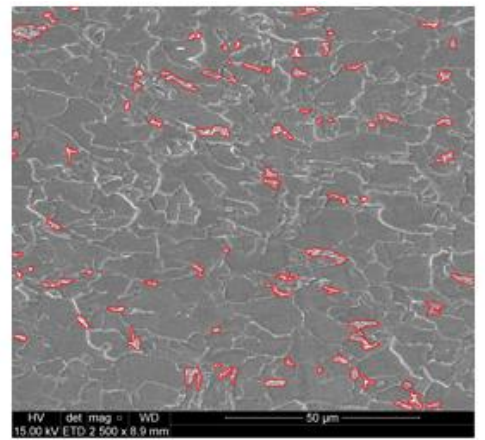

(b)



(e)

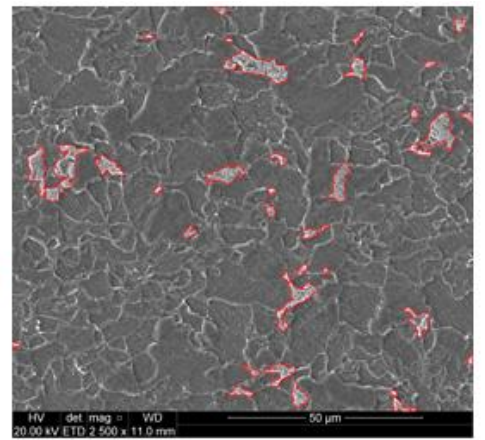

(c)



(f)

Figura 43. Exemplos de micrografias usadas para medição de fração volumétrica de perlita com o analisador de imagens. Aço baixo Mn: (a) seção longitudinal, (b) seção transversal e (c) topo da chapa. Aço alto Mn: (d) seção longitudinal, (e) seção transversal e (f) topo da chapa.

\subsubsection{Tamanho de Grão Ferrítico}

A Tabela 17 apresenta os valores de tamanho médio de grão de ferrita calculados para todas as seções dos dois aços. Para o aço baixo Mn, que foi medido com o método planimétrico além do intercepto linear, e segundo a norma ASTM E112-13 [87], o diâmetro médio do grão pode ser aproximado de acordo com a Equação 17:

$$
d_{\text {Médio }}=\sqrt{A_{\text {Média }}}
$$

Como na Equação 17 o grão é simplificadamente tratado como quadrangular, o valor obtido de $\mathrm{d}_{\text {médio }}$ não possui significado físico relevante, uma vez que a seção de um grão é muito diferente de um quadrado. Assim, o d $\mathrm{d}_{\text {Médio }}$ deve ser considerado uma estimativa e usado para visualizar melhor o resultado de $\mathrm{A}_{\text {Média }}$ dado, que é menos intuitivo do que o de diâmetro.

A Tabela 17 contém as seguintes informações: (i) total de grãos de ferrita contados por seção analisada; para as medidas feitas no aço baixo Mn com o método planimétrico (ii) o número de grãos por unidade de área da circunferência usada $\left(\mathrm{N}_{\mathrm{A}}\right)$, (iii) área média dos grãos 
$\left(\mathrm{A}_{\text {Media }}\right)$ e (iv) diâmetro médio dos grãos $\left(\mathrm{d}_{\text {médio }}\right)$, junto de seus respectivos desvios padrão; para as medidas feitas com o método do intercepto linear, (v) número de grãos por unidade de comprimento da linha de medida $\left(\mathrm{N}_{\mathrm{L}}\right)$ e (vi) intercepto linear médio $(\bar{l})$, também junto dos desvios padrão correspondentes.

Tabela 17. Valores médios de tamanho de grão, calculados pelos métodos Planimétrico e do Intercepto Linear. Número de grãos de ferrita contados, número de grãos por unidade de área $\left(\mathrm{N}_{\mathrm{A}}\right)$, área média dos grãos $\left(\mathrm{A}_{\mathrm{Media}}\right)$, diâmetro médio dos grãos $\left(\mathrm{d}_{\text {Médio }}\right)$, número de grãos por unidade de comprimento $\left(\mathrm{N}_{\mathrm{L}}\right)$, intercepto médio $(\bar{l})$ e seus respectivos desvios padrão, para cada seção dos aços baixo e alto Mn.

\begin{tabular}{|c|c|c|c|}
\hline \multicolumn{4}{|c|}{ Aço Baixo Mn - 0,5\% de Mn (Método Planimétrico) } \\
\hline & Longitudinal & Transversal & Topo \\
\hline $\begin{array}{l}\text { Total de grãos de } \\
\text { ferrita contados }\end{array}$ & 401 & 387 & 398 \\
\hline $\begin{array}{c}\mathrm{N}_{\mathrm{A}}(\text { grãos.mm } \\
\text { desvio padrão }\end{array}$ & $12322,6 \pm 1794,9$ & $11877,0 \pm 946,3$ & $12215,0 \pm 1478,2$ \\
\hline $\begin{array}{l}A_{\text {Media }}\left(\mathbf{m m}^{2}\right) \pm \\
\text { desvio padrão }\end{array}$ & $8,3 \times 10^{-5} \pm 1,2 \times 10^{-5}$ & $8,5 \times 10^{-5} \pm 6,2 \times 10^{-6}$ & $8,3 \times 10^{-5} \pm 9,3 \times 10^{-6}$ \\
\hline $\begin{array}{l}\mathbf{d}_{\text {Médio }}(\mu \mathrm{m}) \pm \\
\text { desvio padrão }\end{array}$ & $9,1 \pm 0,7$ & $9,2 \pm 0,4$ & $9,1 \pm 0,5$ \\
\hline \multicolumn{4}{|c|}{ Aço Baixo Mn - 0,5\% de Mn (Método do Intercepto Linear) } \\
\hline $\begin{array}{l}\text { Total de grãos de } \\
\text { ferrita contados }\end{array}$ & 811 & 872 & 916 \\
\hline $\begin{array}{c}\mathrm{N}_{\mathrm{L}}(\text { grãos.mm } \\
\text { desvio padrão }\end{array}$ & $96,6 \pm 11,7$ & $103,8 \pm 8,1$ & $109,1 \pm 7,2$ \\
\hline $\begin{array}{c}\bar{l}(\mu \mathrm{m}) \pm \text { desvio } \\
\text { padrão }\end{array}$ & $10,5 \pm 1,2$ & $9,7 \pm 0,8$ & $9,2 \pm 0,6$ \\
\hline \multicolumn{4}{|c|}{ Aço Alto Mn - 1,49\% de Mn (Método do Intercepto Linear) } \\
\hline $\begin{array}{l}\text { Total de grãos de } \\
\text { ferrita contados }\end{array}$ & 489 & 816 & 403 \\
\hline $\begin{array}{c}\mathrm{N}_{\mathrm{L}}(\text { grãos.mm } \\
\text { desvio padrão }\end{array}$ & $58,2 \pm 4,4$ & $97,1 \pm 12,8$ & $47,1 \pm 6,1$ \\
\hline $\begin{array}{c}\bar{l}(\mu \mathrm{m}) \pm \text { desvio } \\
\text { padrão }\end{array}$ & $17,3 \pm 1,3$ & $10,4 \pm 1,4$ & $21,2 \pm 3,1$ \\
\hline$\overline{l_{\alpha}}$ & 15,3 & 9,0 & 17,8 \\
\hline
\end{tabular}


A última linha da Tabela 17 corresponde ao valor do intercepto médio linear da ferrita no aço alto Mn, obtido pela Equação 14, reapresentada abaixo, que considera a fração volumétrica de ferrita no material. Portanto, para o cálculo, utilizaram-se os valores de $V_{\mathrm{v}}$ de perlita mostrados pela Tabela 16 do aço alto Mn e as Equações 14 e 18 [84]:

$$
V_{V \alpha}=1-V_{V p e r l i t a}
$$

Os dados da Tabela 17 mostram que o tamanho de grão ferrítico nas três seções do aço baixo Mn é próximo, e que os dois métodos usados para o cálculo forneceram resultados similares. Como era esperado, o tamanho de grão ferrítico no aço alto Mn é maior do que no baixo Mn; e, em concordância com o observado através das micrografias ópticas e eletrônicas de varredura, para o aço alto Mn, o tamanho médio de grão ferrítico é diferente para cada seção: considerando o desvio padrão, o tamanho médio de grão de ferrita das amostras longitudinal e topo são próximos, quase iguais, enquanto que a amostra transversal apresenta tamanho médio de grão menor.

Um dos tipos de informações que podem ser obtidas por EBSD é o diâmetro de grão. As áreas dos grãos são medidas individualmente e, com base nesses valores, diâmetros de grãos são estimados, aproximados como se os grãos tivessem formato circular. Dessa forma são criadas classes de diâmetros de grão, e estas classes são, então, apresentadas na forma de distribuição. A Figura 44 apresenta um exemplo de área analisada na forma de mapa de índice de qualidade (quality index, $Q I$ ) e sua respectiva curva de distribuição de diâmetro de grão. 


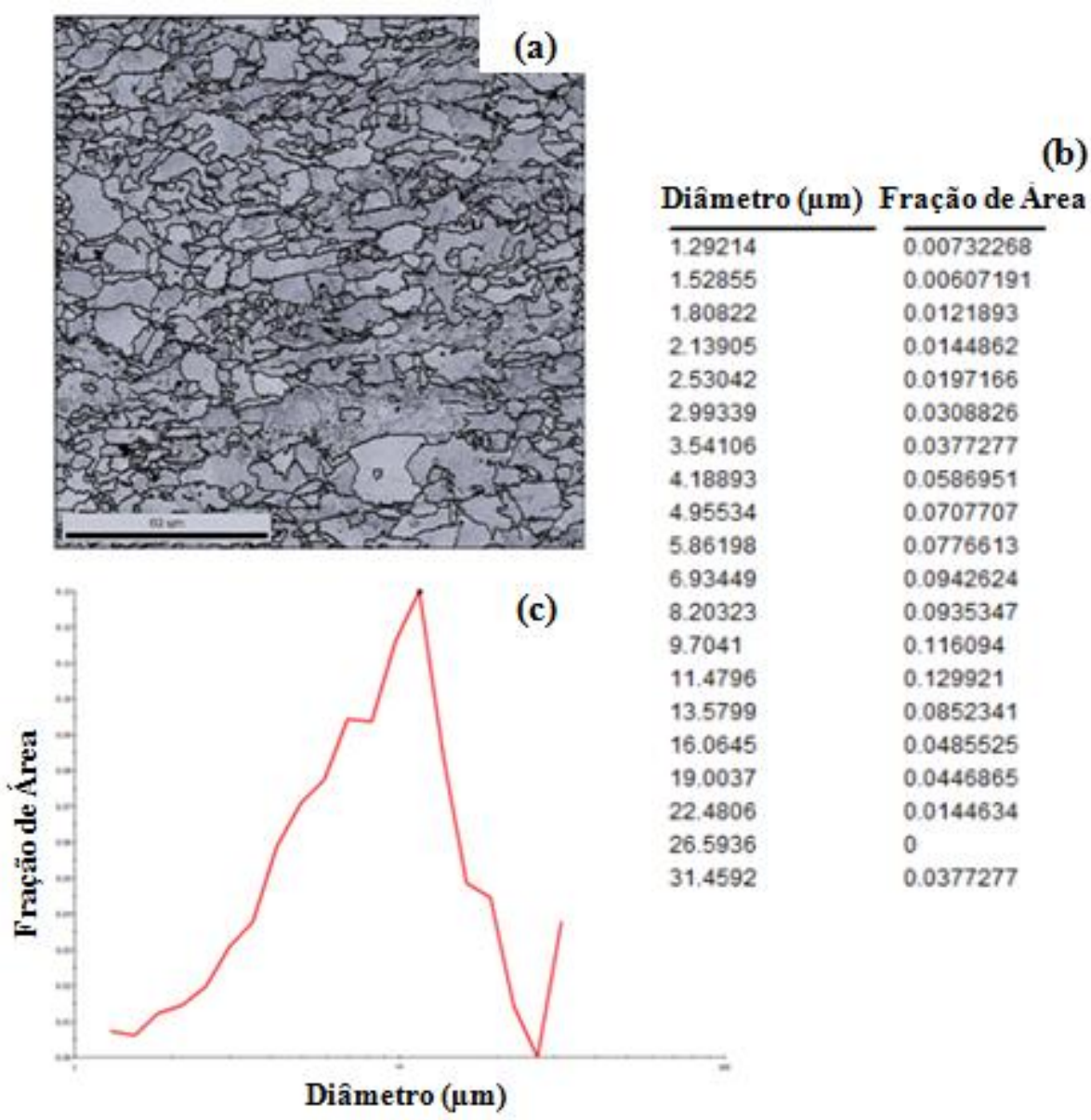

Figura 44. (a) Exemplo de área análisada (frame) por EBSD, (b) tabela com valores de diâmetros de grãos e suas frações de área e (c) curva de distribuição.

As análises de EBSD foram realizadas apenas nas amostras longitudinal, transversal e topo do aço baixo Mn. Para se avaliar quantidade significativa de grãos, fez-se a varredura em três áreas diferentes para cada amostra; portanto, foram obtidas três curvas de distribuição de diâmetro de grão para cada amostra. As frações de área apresentadas são calculadas a partir da Equação 19 abaixo:

$$
\text { Fração de área }=\frac{A_{g r} \text { ãos }, d}{A_{\text {an áliseEBSD }}}
$$

Na Equação 19, Agrãos,d corresponde à área ocupada por grãos de determinada classe de diâmetro d e $\mathrm{A}_{\text {análiseEBSD }}$ é a área total do frame analisado (Figura 44(a)).

Para visualizar melhor a distribuição de tamanho de grão das amostras como um todo, as três áreas de cada frame foram somadas e uma nova distribuição, contendo todos os diâmetros medidos, foi obtida. Para esta nova distribuição $\mathrm{A}_{\text {análiseEBSD }}$ corresponde à soma das áreas dos três frames. As Figuras 45, 46 e 47 contêm as curvas de distribuição de diâmetro de 
grão para as amostras longitudinal, transversal e topo, respectivamente; a Figura 48 apresenta os resultados para todas as amostras juntas.

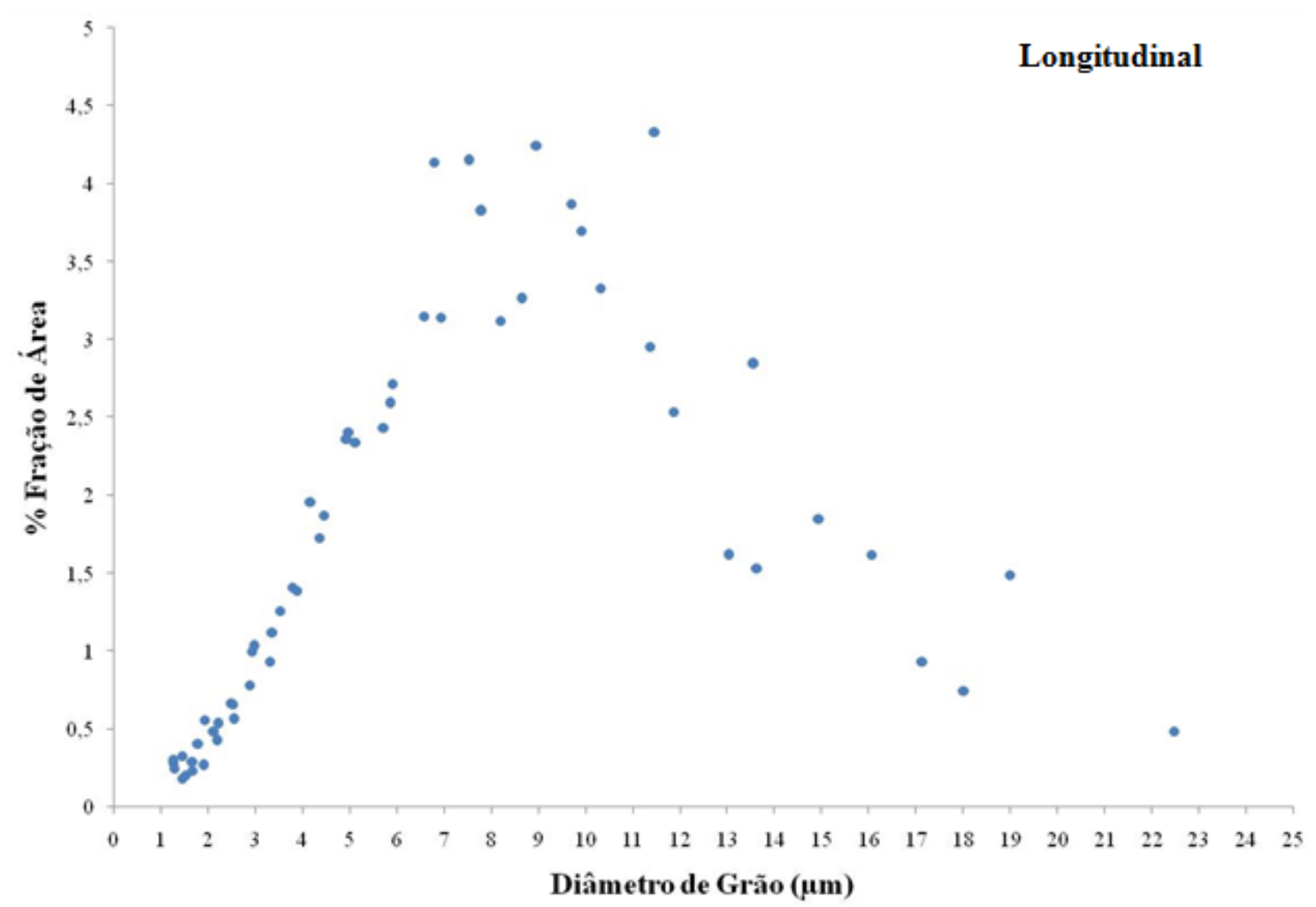

Figura 45. Distribuição de diâmetro de grão para amostra longitudinal do aço baixo Mn.

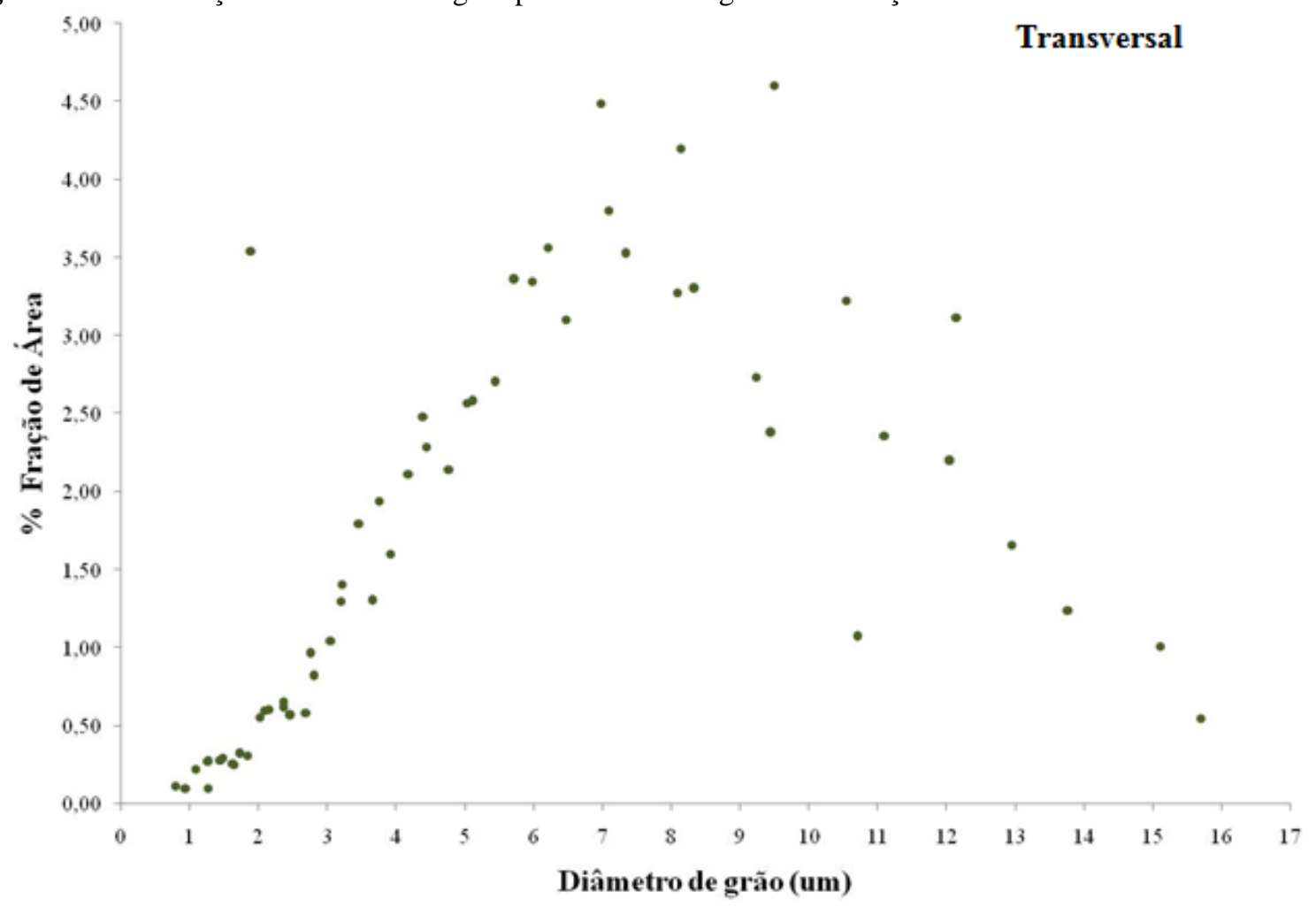

Figura 46. Distribuição de diâmetro de grão para amostra transversal do aço baixo Mn. 


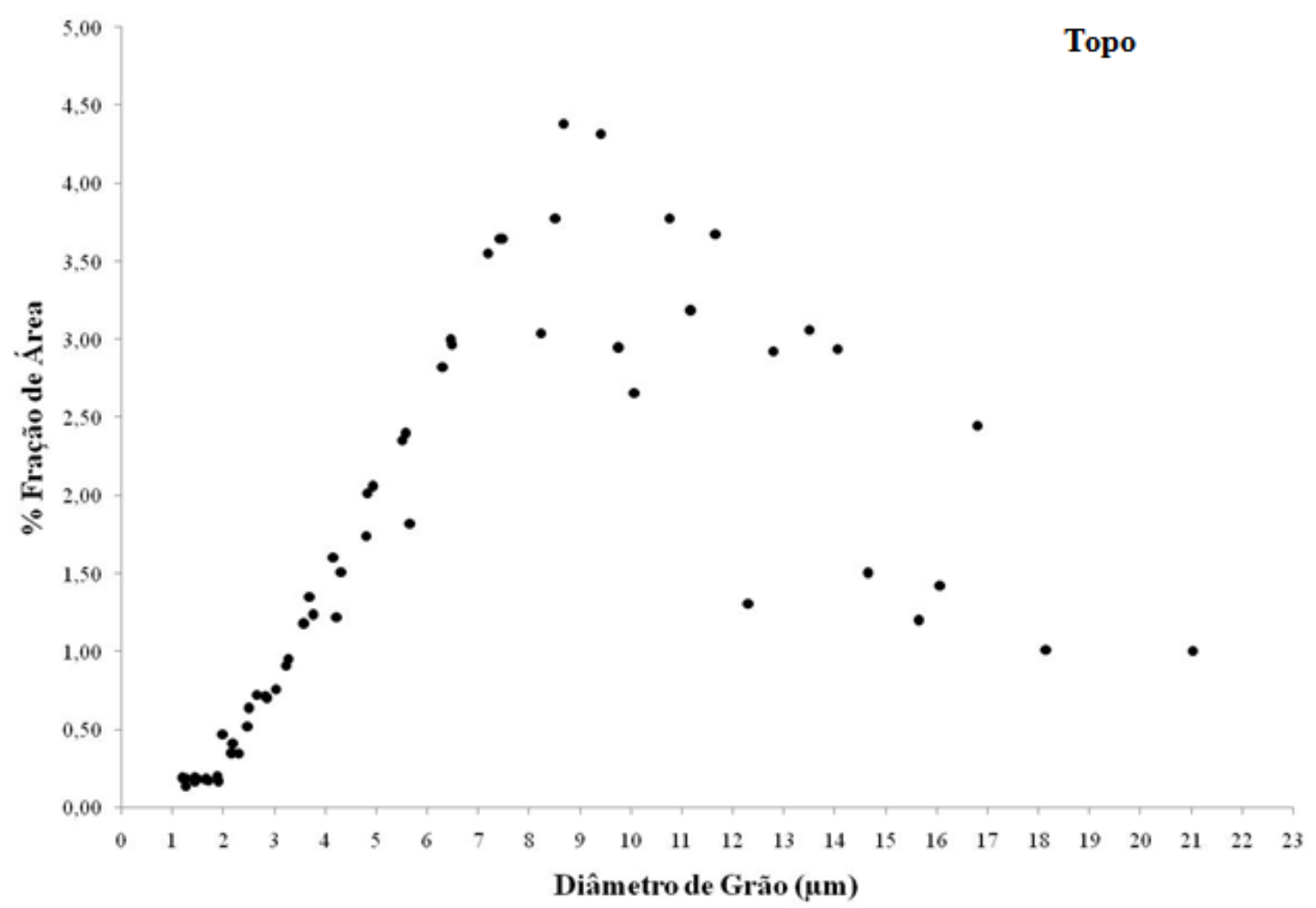

Figura 47. Distribuição de diâmetro de grão para amostra topo do aço baixo Mn.

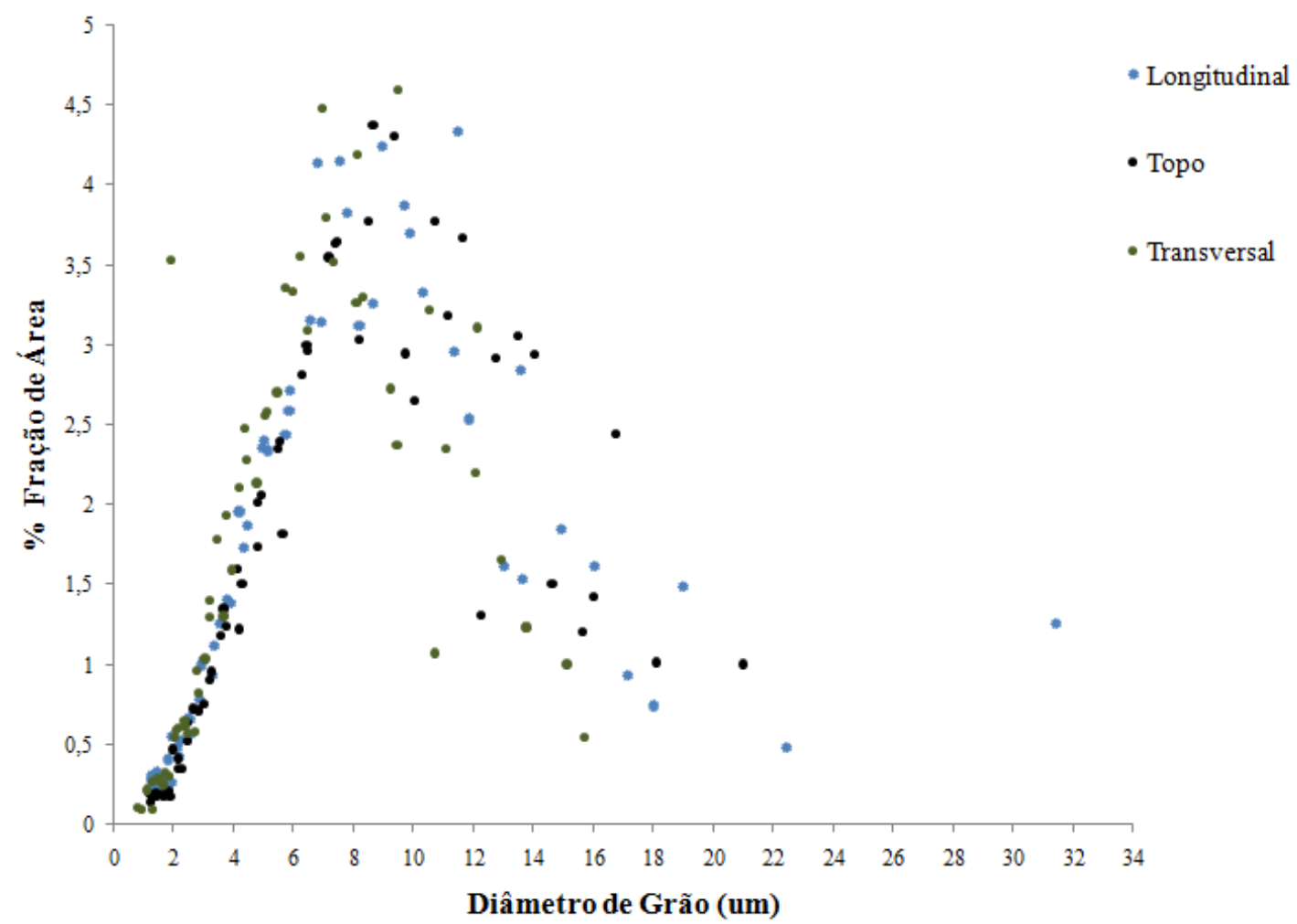

Figura 48. Comparação das curvas de distribuição de diâmetro de grão para todas as amostras do aço baixo Mn. 
Para descrever as distribuições apresentadas pelas Figuras 45-47, calculou-se a média ponderada dos diâmetros dos grãos, utilizando a fração de área ocupada por cada classe de grão como os pesos. $\mathrm{O}$ desvio padrão ponderado corresponde a uma medida da dispersão dos valores de diâmetros na distribuição, não ao erro da medida; estes valores são mostrados na Tabela 18.

Tabela 18. Valores médios ponderados dos diâmetros dos grãos, determinados por EBSD, e seus respectivos desvios padrão ponderados, para cada amostra do aço baixo Mn. Lembrando que os desvios padrão ponderados correspondem a uma medida da dispersão dos valores de diâmetros na distribuição.

\begin{tabular}{|c|c|c|c|}
\hline Amostra & Longitudinal & Topo & Transversal \\
\hline $\begin{array}{c}\text { Valor Médio } \\
\text { ponderado }(\boldsymbol{\mu m}) \pm \\
\text { desvio padrão } \\
\text { ponderado }\end{array}$ & $8,4 \pm 4,8$ & $8,5 \pm 4,1$ & $7,1 \pm 3,3$ \\
\hline
\end{tabular}

As curvas de distribuição e as médias ponderadas mostram que os valores de tamanho de grão para as três amostras são similares entre si, sendo o da amostra transversal ligeiramente mais baixo, e, também, próximos dos valores calculados pelos métodos planimétrico e do intercepto linear.

\subsubsection{3 Área superficial de contornos de grão por unidade de volume} $\left(\mathbf{S}_{\mathrm{v}}\right)$

A Tabela 19 apresenta os valores de área superficial de contornos de grão por unidade de volume, $S_{v}$, calculados para os dois aços, com métodos do intercepto diferentes: método do Intercepto Circular de Hilliard para o aço baixo Mn e método do Intercepto Linear para os dois aços. A justificativa para utilização de dois métodos é dada na seção 4.2.3.3. Além destes resultados, são informados os totais de grãos contados e os números de grãos por unidade de comprimento $\left(\mathrm{N}_{\mathrm{L}}\right)$ para cada seção analisada, acompanhados de seus desvios padrão. 
Tabela 19. Total de grãos de ferrita contados, número de grãos por unidade de comprimento (NL), área superficial de contornos de grão por unidade de volume (Sv) e seus respectivos desvios padrão, obtidos pelo método do Intercepto Circular de Hilliard (aço baixo Mn) e pelo método do Intercepto Linear (dois aços).

\begin{tabular}{|c|c|c|c|}
\hline \multicolumn{4}{|c|}{ Aço Baixo Mn - 0,5\% de Mn (Método do Intercepto Circular de Hilliard) } \\
\hline & Longitudinal & Transversal & Topo \\
\hline $\begin{array}{l}\text { Total de grãos de } \\
\text { ferrita contados }\end{array}$ & 299 & 345 & 284 \\
\hline $\begin{array}{c}\mathrm{N}_{\mathrm{L}}(\mathrm{grãos} / \mathrm{mm}) \pm \\
\text { desvio padrão }\end{array}$ & $148,1 \pm 15,2$ & $170,8 \pm 12,2$ & $140,6 \pm 18,4$ \\
\hline $\begin{array}{c}\mathrm{S}_{\mathrm{v}}\left(\mathrm{mm}^{2} / \mathrm{mm}^{3}\right) \pm \\
\text { desvio padrão }\end{array}$ & $296,1 \pm 30,5$ & $341,7 \pm 24,4$ & $281,2 \pm 36,8$ \\
\hline \multicolumn{4}{|c|}{ Aço Alto Mn - 1,49\% de Mn (Método do Intercepto Linear) } \\
\hline $\begin{array}{l}\text { Total de grãos de } \\
\text { ferrita contados }\end{array}$ & 503,00 & 646 & 465 \\
\hline $\begin{array}{c}\mathrm{N}_{\mathrm{L}}(\mathrm{grãos} / \mathrm{mm}) \pm \\
\text { desvio padrão }\end{array}$ & $78,4 \pm 10,4$ & $100,7 \pm 12,9$ & $72,5 \pm 8,2$ \\
\hline $\begin{array}{c}\mathrm{S}_{\mathrm{v}}\left(\mathrm{mm}^{2} / \mathrm{mm}^{3}\right) \pm \\
\text { desvio padrão }\end{array}$ & $313,8 \pm 42,7$ & $403,0 \pm 51,6$ & $290,1 \pm 33,0$ \\
\hline
\end{tabular}

Para o aço baixo Mn, com base nos desvios padrão obtidos, pode-se dizer que os valores de $S_{\mathrm{v}}$ são próximos para as três seções, assim como são os seus valores de tamanho de grão. Para o aço alto $\mathrm{Mn}$ os resultados de $\mathrm{S}_{\mathrm{v}}$ também se mostraram coerentes com os valores de tamanho de grão apresentados pela Tabela 17. A amostra transversal tem, expressivamente, menor tamanho de grão e, como esperado, a quantidade de área de contornos de grão por unidade de volume foi mais elevada. Em seguida, o $S_{\mathrm{v}}$ da amostra longitudinal foi o segundo maior, concordando com seu valor de tamanho de grão, seguido do $S_{v}$ da amostra topo. Ainda, o $S_{\mathrm{v}}$ do aço alto Mn considera, de modo aproximado, as interfaces ferrita-perlita, enquanto que o $S_{v}$ do aço baixo $M n$ conta apenas os contornos de grão ferríticos - a fração volumétrica de perlita neste último aço é muito baixa e, por isso, pode ser considerado como constituído apenas por ferrita.

\subsubsection{Comprimento de grãos de ferrita no aço baixo Mn}

As análises de EBSD também forneceram o comprimento de contornos de grão presentes nas superfícies examinadas. Os contornos foram classificados, de acordo com seus 
ângulos de rotação, em: (i) baixo ângulo, com rotações entre $2^{\circ}$ e $5^{\circ}$; (ii) médio ângulo, entre $5^{\circ}$ e $15^{\circ}$; e (iii) alto ângulo,com rotações entre $15^{\circ}$ e $180^{\circ}$. O programa utilizado para obtenção dos resultados de EBSD, TSL OIM Analysis, contou como contorno de grão qualquer par de pontos com misorientação superior a $2^{\circ}$. A Figura 49 apresenta exemplos de mapas de EBSD de índice de qualidade (QI) e de contornos de grão, um para cada condição analisada do aço baixo Mn. A Tabela 20 mostra os comprimentos dos diferentes contornos de grão, também para cada seção e suas três diferentes áreas analisadas.
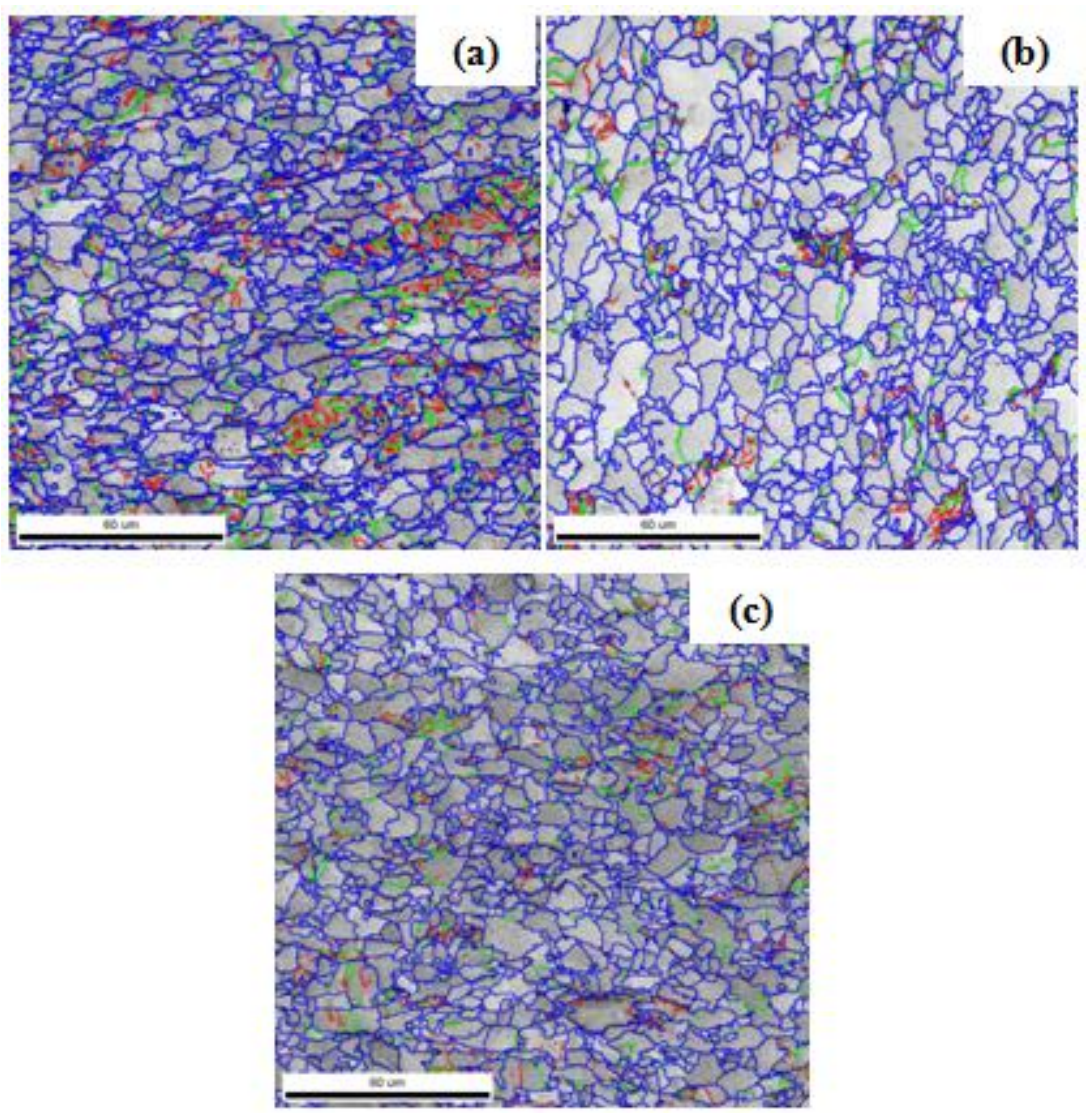

Figura 49. Mapas de índice de qualidade (QI) e de contornos de grão. Contornos em azul: alto ângulo (entre $15^{\circ}$ e $180^{\circ}$ ); em verde: médio ângulo (entre $5^{\circ}$ e $15^{\circ}$ ) e em vermelho: baixo ângulo (entre $2^{\circ}$ e $5^{\circ}$ ). Em (a) amostra longitudinal, (b) topo e (c) transversal do aço baixo Mn. 
Tabela 20. Comprimentos de contornos de grãos em cada amostra analisada por EBSD do aço baixo Mn. As áreas correspondem aos campos analisados para cada amostra.

\begin{tabular}{|c|c|c|c|c|}
\hline \multicolumn{5}{|c|}{ Longitudinal } \\
\hline & \multicolumn{4}{|c|}{ Comprimento $(\mathrm{cm})$} \\
\hline $\begin{array}{c}\text { Tipo de } \\
\text { contorno }\end{array}$ & Área 1 & Área 2 & Área 3 & Soma dos comprimentos das 3 áreas \\
\hline $\begin{array}{c}2^{\circ} \mathbf{e}^{\circ} \text { (baixo } \\
\text { ângulo, } \\
\text { vermelho) }\end{array}$ & 0,22 & 0,37 & 0,27 & 0,86 \\
\hline $\begin{array}{l}5^{\circ} \text { e } 15^{\circ} \text { (médio } \\
\text { ângulo, verde) }\end{array}$ & 0,18 & 0,25 & 0,22 & 0,65 \\
\hline $\begin{array}{c}15^{\circ} \text { e } 180^{\circ} \\
\text { (médio ângulo, } \\
\text { verde) }\end{array}$ & 1,20 & 1,23 & 1,36 & 3,79 \\
\hline Total & 1,60 & 1,84 & 1,85 & 5,29 \\
\hline \multicolumn{5}{|c|}{ Topo } \\
\hline & \multicolumn{4}{|c|}{ Comprimento (cm) } \\
\hline $\begin{array}{l}\text { Tipo de } \\
\text { contorno }\end{array}$ & Área 1 & Área 2 & Área 3 & Soma dos comprimentos das 3 áreas \\
\hline $\begin{array}{c}2^{\circ} \text { e }^{\circ} \text { (baixo } \\
\text { ângulo, } \\
\text { vermelho) }\end{array}$ & 0,12 & 0,11 & 0,08 & 0,31 \\
\hline $\begin{array}{l}5^{\circ} \text { e } 15^{\circ} \text { (médio } \\
\text { ângulo, verde) }\end{array}$ & 0,12 & 0,12 & 0,10 & 0,33 \\
\hline $\begin{array}{l}15^{\circ} \text { e } 180^{\circ} \text { (alto } \\
\text { ângulo, verde) }\end{array}$ & 1,12 & 1,15 & 1,12 & 3,39 \\
\hline Total & 1,35 & 1,37 & 1,30 & 4,02 \\
\hline \multicolumn{5}{|c|}{ Transversal } \\
\hline & \multicolumn{4}{|c|}{ Comprimento $(\mathrm{cm})$} \\
\hline $\begin{array}{l}\text { Tipo de } \\
\text { contorno }\end{array}$ & Área 1 & Área 2 & Área 3 & Soma dos comprimentos das 3 áreas \\
\hline $\begin{array}{c}2^{\circ} \text { e }^{\circ} \text { (baixo } \\
\text { ângulo, } \\
\text { vermelho) }\end{array}$ & 0,19 & 0,14 & 0,16 & 0,49 \\
\hline $\begin{array}{l}5^{\circ} \text { e } 15^{\circ} \text { (médio } \\
\text { ângulo, verde) }\end{array}$ & 0,20 & 0,13 & 0,14 & 0,47 \\
\hline $\begin{array}{l}15^{\circ} \text { e } 180^{\circ} \text { (alto } \\
\text { ângulo, verde) }\end{array}$ & 1,41 & 1,39 & 1,34 & 4,14 \\
\hline Total & 1,80 & 1,66 & 1,64 & 5,09 \\
\hline
\end{tabular}

Os comprimentos de contornos de grão determinados por EBSD são resultados importantes, pois permitem que se analise de modo mais detalhado esta característica da microestrutura. Para o cálculo de $S_{v}$ com os métodos de intercepto não se fez distinção dos 
tipos de contornos de grão: na verdade, apenas os contornos de alto ângulo foram contados, já que são mais facilmente visualizados do que os demais. Outras diferenças entre os métodos de intercepto e as medições com EBSD que devem ser consideradas são: (1) o aumento usado para análise com EBSD foi de $1500 \mathrm{x}$, enquanto que para o cálculo de $\mathrm{S}_{\mathrm{v}}$ trabalhou-se com imagens obtidas com aumento de 2500 x e (2) não se fez tratamento estatístico dos resultados obtidos por EBSD, uma vez que o número de repetições não é alto o suficiente para isso.

Ao se olhar apenas para os valores de comprimento de contornos de alto ângulo, observa-se que, assim como com os valores de $S_{v}$, a amostra topo apresenta menor comprimento de contornos, seguida da amostra longitudinal e, por último, da transversal. Quando os contornos de baixo e médio ângulo são contabilizados, a amostra topo continua sendo a que apresenta menor quantidade de contornos e as amostras longitudinal e transversal mostram valores muito próximos $-5,29 \mathrm{~cm}$ e $5,09 \mathrm{~cm}$, respectivamente; as duas têm, aproximadamente, $1 \mathrm{~cm}$ a mais de comprimento de contornos do que a amostra topo. A diferença entre os resultados de $S_{\mathrm{v}}$ e de comprimento de contornos de grão está nas quantidades de contornos de baixo e médio ângulo, maiores para a amostra longitudinal.

\subsection{Microdureza Vickers}

Os valores médios de microdureza Vickers para os dois aços são apresentados pela Tabela 21. Para as amostras longitudinal e transversal as medidas foram realizadas ao longo da espessura, porém, não na forma de perfil de dureza: não se definiu uma distância fixa entre cada endentação e também as medidas não foram realizadas nas bordas das chapas - pode-se considerar que foram feitas abaixo da região (i) e acima da região (v) ilustradas na Figura 20. Para as amostras topo, as medidas foram feitas de maneira aleatória por toda a superfície.

Tabela 21. Valores médios de microdureza e seus respectivos desvios padrão (DV) para as seções longitudinal, transversal e topo dos dois aços.

\begin{tabular}{|c|c|c|c|}
\hline \multicolumn{4}{|c|}{ Aço baixo Mn (0,5\% em massa de Mn) } \\
\hline Amostra & Longitudinal & Tranversal & Topo \\
\hline HV (0,3 kg) \pm DV & $202 \pm 3$ & $202 \pm 3$ & $191 \pm 6$ \\
\hline \multicolumn{4}{|c|}{ Aço alto Mn (1,49\% em massa de Mn) } \\
\hline Amostra & Longitudinal & Tranversal & Topo \\
\hline HV (0,3 kg) \pm DV & $205 \pm 4$ & $201 \pm 6$ & $207 \pm 5$ \\
\hline
\end{tabular}


Os valores médios de dureza dos dois aços são parecidos e não se observou variação significativa da dureza em função da seção analisada.

O perfil de dureza para cada aço havia sido levantado por outros integrantes do grupo de pesquisa do LTF $[18,95]$, antes do período de início do presente mestrado. Por isso estes tipos de medidas não foram repetidos. Ogata [18], em sua dissertação de metrado, apresentou o perfil de microdureza Vickers ao longo da espessura da chapa de aço alto Mn e, para realizar as medições, utilizou a mesma carga de 0,3 kg. Em seu trabalho, Ogata [18] mostrou que a dureza varia ao longo da espessura da chapa: as regiões das bordas da chapa têm dureza mais elevada do que o centro da chapa, em torno de $220 \mathrm{HV}$ para a borda superior, aproximadamente $195 \mathrm{HV}$ para o centro da chapa e $205 \mathrm{HV}$ para a borda inferior [18]. Os valores medidos por Ogata [18] concordam com os apresentados pela Tabela 21. Ainda, Ogata [18] mediu a microdureza em uma banda central, composta por agregados eutetóides, e em uma região formada apenas por ferrita, e obteve que a dureza média da ferrita era em torno de $186 \pm 12 \mathrm{HV}$ e no agregado eutetóide, de $251 \pm 22$ HV. Hernández [95] fez caracterização microestrutural, de propriedades mecânicas e ensaios de HIC no aço baixo Mn, medindo o perfil de microdureza Vickers deste aço. A carga utilizada também foi de $0,3 \mathrm{~kg}$ e não houve variação significativa no valor da dureza em função da espessura da chapa. A dureza média encontrada foi de $213 \pm 8 \mathrm{HV}$; valor comparável ao que foi apresentado pela Tabela 21 [95].

\subsection{Análise de textura por EBSD}

O motivo principal para utilização da técnica de EBSD foi determinar as texturas cristalográficas nas três seções do aço baixo Mn. Em aços laminados a frio, a textura é normalmente mais pronunciada nas seções que contém planos paralelos à direção e ao sentido de laminação; em aços laminados a quente, no entanto, segundo [96], não são desenvolvidas fortes texturas ou gradientes de textura, uma vez que os mesmos passam pela transformação da austenita em ferrita durante o resfriamento, o que torna a textura em grande parte aleatória [96]. A textura e a microestrutura dos aços laminados costumam ser heterogêneas ao longo da espessura das chapas [96] e, por esta razão, as análises de EBSD são feitas em amostras retiradas de diferentes camadas das chapas. No presente trabalho isso não foi considerado porque o interesse maior era na superfície do topo da chapa, na qual os ensaios de permeabilidade ao hidrogênio foram realizados e que tem contato direto com o meio sour. 
A Figura 50 abaixo apresenta os mapas de figura de polo inverso (Inverse Pole Figures, IPF) combinados com o índice de qualidade (Quality Index, QI) para as amostras longitudinal, transversal e topo do aço baixo Mn. São mostradas as três áreas analisadas de cada amostra.
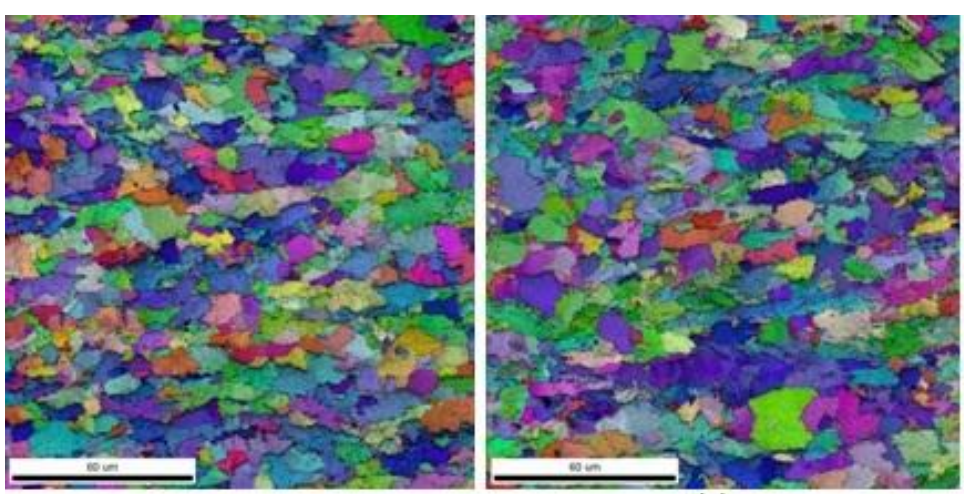

(a)
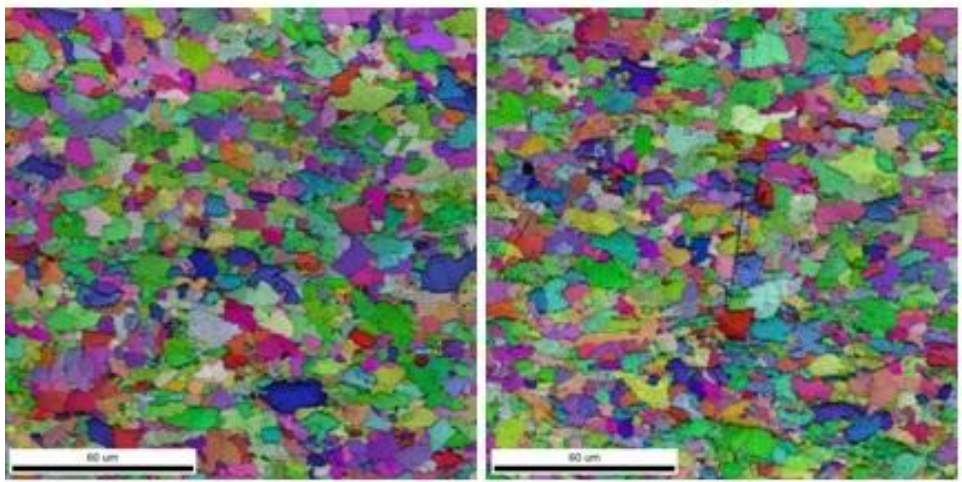

(b)
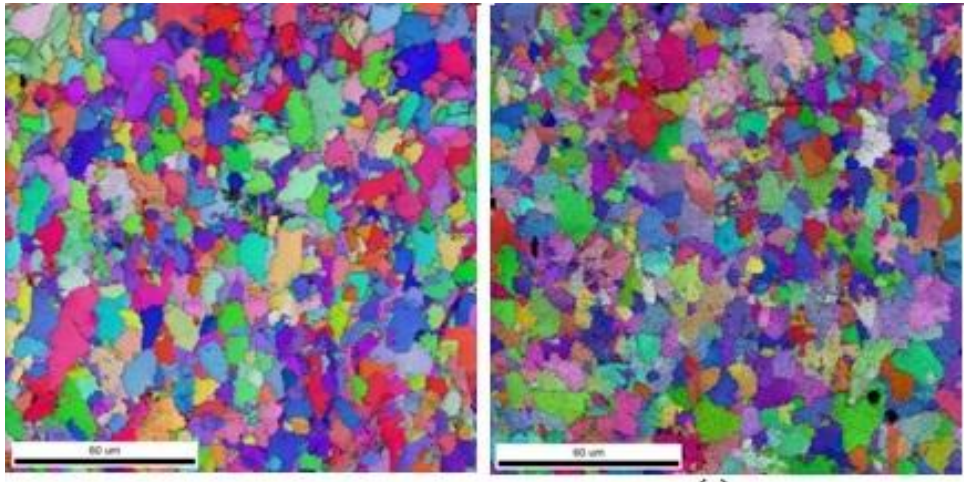

(c)

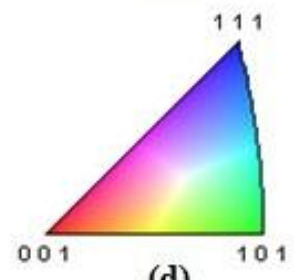

(d)
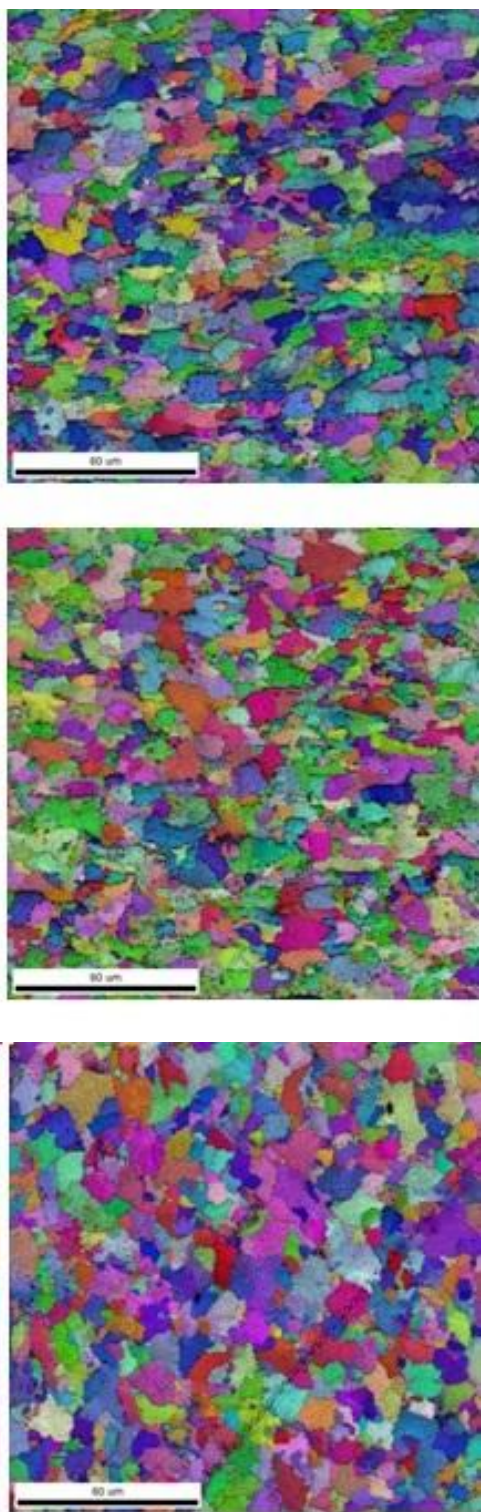

(ب)




Através dos mapas apresentados pela Figura 50 é possível dizer que, qualitativamente, a amostra longitudinal aparenta ter a maior parte de seus grãos nas superfícies $\{111\}$ (azuis), seguidos de $\{101\}$ (verdes). A amostra transversal, por sua vez, parece ter quantidade de grãos na superfícies $\{101\}$ levemente superior às $\{001\}$, seguido de $\{111\}$; enquanto que a amostra topo tende a apresentar textura mais aleatória, como era esperado, uma vez que o aço baixo Mn passou pelo processo termomecânico de laminação controlada, que envolve laminação a quente e transformação da austenita em ferrita.

Os resultados de EBSD aqui apresentados são preliminares e precisam ser mais explorados em trabalhos futuros.

\subsection{Permeabilidade ao Hidrogênio}

Para facilitar o entendimento dos resultados, algumas definições e equações apresentadas na seção 3.6. Ensaio de permeabilidade ao hidrogênio, da Revisão Bibliográfica, serão reproduzidas abaixo:

- $\quad D_{\text {eff }}\left(\mathrm{cm}^{2} \cdot \mathrm{s}^{-1}\right)$ : o coeficiente de difusão efetiva do hidrogênio no aço, ou seja, que considera a presença de traps reversíveis e irreversíveis na estrutura do material;

- $\quad \mathrm{C}_{0}\left(\mathrm{~mol} . \mathrm{cm}^{-3}\right)$ : concentração de hidrogênio atômico na sub-superfície da face de carregamento da amostra;

- $\quad \mathrm{N}_{\mathrm{t}}\left(\mathrm{cm}^{-3}\right)$ : número de sítios de aprisionamento de $\mathrm{H}$ por unidade de volume.

Esses resultados são obtidos a partir de informações contidas nas curvas de permeabilidade, do valor de espessura da amostra e das Equações 1-6:

$$
\begin{gathered}
D_{e f f}=\frac{e^{2}}{6 t_{\text {lag }}} \\
D_{e f f}=\frac{e^{2}}{15,3 t_{b}} \\
C_{0}=\frac{J_{\infty} e}{D_{e f f}} \\
J=\frac{I}{A F} \\
N_{T}=\frac{C_{0}}{3}\left(\frac{D_{l}}{D_{e f f}}-1\right) \\
T=\frac{t}{e^{2}}
\end{gathered}
$$


Nas quais: $\mathrm{e}=$ espessura da amostra em $\mathrm{cm} ; \mathrm{t}_{\mathrm{lag}}=$ tempo em que $\mathrm{i}=0,63 I_{\infty} ; \mathrm{t}_{\mathrm{b}}=$ tempo decorrido para que os primeiros átomos de hidrogênio atravessem a amostra; $J_{\infty}=$ fluxo de hidrogênio atômico no estado estacionário; $\mathrm{J}$ = fluxo de hidrogênio atômico, em mol.s $\mathrm{s}^{-1} . \mathrm{cm}^{-2}$; $\mathrm{I} / \mathrm{A}=$ densidade de corrente (corrente dividida pela área da amostra exposta ao eletrólito); $\mathrm{F}=$ constante de Faraday, 9,6485 x $10^{4} \mathrm{C}_{\mathrm{mol}}{ }^{-1}$ e $\mathrm{D}_{\mathrm{l}}=$ coeficiente de difusão de rede do $\mathrm{H}$.

As amostras de seções longitudinais, transversais e do topo das chapas dos dois aços foram submetidas a ensaios de permeabilidade ao $\mathrm{H}$ e passaram pelo tratamento de dados descrito na seção 3.5, Equações 1-6 (parte da revisão bibliográfica que trata de permeabilidade ao hidrogênio). Com exceção do cálculo de $\mathrm{C}_{0}$, que depende do valor de $J_{\infty}$, os demais parâmetros foram determinados utilizando-se os dados não normalizados, para minimização de erros no valor final - erros provenientes de arredondamentos.

As Tabelas 22 e 23 apresentam os valores de coeficiente de difusão efetiva, $D_{\text {eff, }}$ calculados pelos métodos do $\mathrm{t}_{\mathrm{lag}} \mathrm{e}$ do $\mathrm{t}_{\mathrm{b}}$, para o aço baixo $\mathrm{Mn}$ e para o alto $\mathrm{Mn}$, respectivamente.

Tabela 22. Valores de coeficiente de difusão efetiva, $\mathrm{D}_{\text {eff }}$, calculados pelos métodos do time-lag $\left(\mathrm{t}_{\text {lag }}\right)$ e do timebreakthrough $\left(\mathrm{t}_{\mathrm{b}}\right)$, espessuras das amostras $(\mathrm{e})$ e valores de corrente no estado estacionário $\left(\mathrm{I}_{\infty}\right)$, para o aço baixo Mn.

\begin{tabular}{|c|c|c|c|c|c|c|}
\hline \multicolumn{7}{|c|}{ Aço Baixo Mn (0,5 Mn) } \\
\hline & e (cm) & $I_{\infty}(\mu \mathbf{A})$ & $\mathbf{t}_{\text {lag }}(\mathbf{s})$ & $\begin{array}{r}D_{\text {eff }} t_{\text {lag }} \\
\left(\mathrm{cm}^{2} \cdot \mathrm{s}^{-1}\right)\end{array}$ & $\mathbf{t}_{\mathbf{b}}(\mathbf{s})$ & $\begin{array}{c}D_{\text {eff }} t_{b} \\
\left(\mathrm{~cm}^{2} \cdot \mathbf{s}^{-1}\right)\end{array}$ \\
\hline \multirow{3}{*}{ Longitudinal } & 0,145 & 84,8 & 534,6 & $6,6 \times 10^{-6}$ & 210,0 & $6,5 \times 10^{-6}$ \\
\hline & 0,128 & 95,7 & 523,8 & $5,2 \times 10^{-6}$ & 140,0 & $7,7 \times 10^{-6}$ \\
\hline & - & - & - & - & - & - \\
\hline \multirow{3}{*}{ Transversal } & 0,119 & 124,5 & 442,8 & $5,4 \times 10^{-6}$ & 162,0 & $5,8 \times 10^{-6}$ \\
\hline & 0,098 & 135,7 & 340,2 & $4,7 \times 10^{-6}$ & ND & ND \\
\hline & 0,180 & 103,7 & 766,8 & $6,8 \times 10^{-6}$ & 350,0 & $5,9 \times 10^{-6}$ \\
\hline \multirow{3}{*}{ Topo } & 0,128 & 97,0 & 626,4 & $4,4 \times 10^{-6}$ & 250,0 & $4,3 \times 10^{-6}$ \\
\hline & 0,096 & 93,2 & 878,4 & $1,8 \times 10^{-6}$ & 230,0 & $2,6 \times 10^{-6}$ \\
\hline & 0,163 & 68,9 & 1468,8 & $3,0 \times 10^{-6}$ & 600,0 & $2,9 \times 10^{-6}$ \\
\hline
\end{tabular}


Tabela 23. Valores de coeficiente de difusão efetiva, $\mathrm{D}_{\text {eff }}$, calculados pelos métodos do time-lag $\left(\mathrm{t}_{\text {lag }}\right)$ e do timebreakthrough $\left(\mathrm{t}_{\mathrm{b}}\right)$, espessuras das amostras (e) e valores de corrente no estado estacionário $\left(\mathrm{I}_{\infty}\right)$, para o aço alto $\mathrm{Mn}$.

\begin{tabular}{|c|c|c|c|c|c|c|}
\hline \multicolumn{7}{|c|}{ Aço Alto Mn (1,49 Mn) } \\
\hline & e $(\mathbf{c m})$ & $\boldsymbol{I}_{\infty}(\boldsymbol{\mu} \mathbf{A})$ & $\mathbf{t}_{\text {lag }}(\mathbf{s})$ & $\begin{array}{r}D_{\text {eff }} \mathbf{t}_{\text {lag }} \\
\left(\mathrm{cm}^{2} \cdot \mathbf{s}^{-1}\right)\end{array}$ & $\mathbf{t}_{\mathbf{b}}(\mathbf{s})$ & $\begin{array}{c}D_{\text {eff }} \mathbf{t}_{\mathrm{b}} \\
\left(\mathrm{cm}^{2} \cdot \mathrm{s}^{-1}\right)\end{array}$ \\
\hline \multirow{3}{*}{ Longitudinal } & 0,157 & 61,2 & 772,2 & $5,3 \times 10^{-6}$ & 360,0 & $4,5 \times 10^{-6}$ \\
\hline & 0,142 & 63,7 & 820,8 & $4,1 \times 10^{-6}$ & 300,0 & $4,4 \times 10^{-6}$ \\
\hline & 0,167 & 59,5 & 993,6 & $4,7 \times 10^{-6}$ & 450,0 & $4,1 \times 10^{-6}$ \\
\hline \multirow{3}{*}{ Transversal } & 0,152 & 63,8 & 799,2 & $4,8 \times 10^{-6}$ & 318,6 & $4,7 \times 10^{-6}$ \\
\hline & 0,161 & 59,7 & 766,8 & $5,6 \times 10^{-6}$ & 250,0 & $6,8 \times 10^{-6}$ \\
\hline & 0,152 & 62,8 & 788,4 & $4,9 \times 10^{-6}$ & 318,6 & $4,7 \times 10^{-6}$ \\
\hline \multirow{3}{*}{ Topo } & 0,098 & 81,9 & 360 & $4,5 \times 10^{-6}$ & 136,8 & $4,6 \times 10^{-6}$ \\
\hline & 0,084 & 59,9 & 421,2 & $2,8 \times 10^{-6}$ & 120,0 & $3,9 \times 10^{-6}$ \\
\hline & 0,131 & 53,3 & 831,6 & $3,4 \times 10^{-6}$ & 390,0 & $2,9 \times 10^{-6}$ \\
\hline
\end{tabular}

Como o número de ensaios repetidos que deram certo foi relativamente baixo, em vez de se calcular média e desvio padrão optou-se por apresentar os três resultados associados às melhores curvas de permeabilidade obtidas, ou seja, com perfis mais próximos ao ideal apresentado pela Figura 18. Somente para a amostra longitudinal do aço baixo Mn dois resultados foram utilizados, não foi possível obter um terceiro, devido a problemas externos ao ensaio. Boa parte dos valores de $\mathrm{D}_{\text {eff }}$ calculados pelo método do $\mathrm{t}_{\mathrm{lag}}$ foram próximos dos $\mathrm{D}_{\mathrm{eff}} \mathrm{t}_{\mathrm{b}}$, o que pode ser considerado um indicador da qualidade das curvas de permeabilidade obtidas experimentalmente. A determinação de $t_{b}$ é facilmente comprometida por qualquer instabilidade do arranjo experimental no momento em que o ensaio é realizado, levando a irregularidades no início da curva e no transiente. Como mais da metade dos $D_{\text {eff }}$ obtidos pelos dois métodos concordou entre si, pode-se afirmar que as curvas que originaram os resultados das Tabelas 22 e 23 mediram realmente o comportamento do $\mathrm{H}$ e não foram comprometidas por eventos externos. Contudo, apesar dos bons resultados de $t_{b}$, devido à maior confiabialidade proporcionada pelo $t_{\text {lag }}$, para cálculos de $\mathrm{N}_{\mathrm{t}}$ e $\mathrm{C}_{0}$ foram usados os valores de $\mathrm{D}_{\text {eff }} \mathrm{t}_{\text {lag. }}$.

As Tabelas 22 e 23 mostram o seguinte: (1) os $D_{\text {eff }} t_{\text {lag }}$ das amostras longitudinais são iguais aos das amostras transversais, tanto para o aço baixo Mn como para o aço alto Mn; (2) ao se comparar as seções dos dois aços, ou seja, seção longitudinal do aço baixo Mn com seção longitudinal do aço alto Mn e assim por diante, observa-se que os $\mathrm{D}_{\text {eff }}$ dos dois aços são 
muito próximos, mas que existe uma tendência do aço baixo Mn ter $\mathrm{D}_{\text {eff }}$ um pouco mais elevados e (3) as amostras dos topos das duas chapas de aços apresentam alta dispersão nos valores de $\mathrm{D}_{\text {eff }} \mathrm{e}$, na média, estes coeficientes são menores do que as outras duas seções.

Como se pode observar por meio de comparação das Tabelas 22 e 23 com a Tabela 5, os valores de $\mathrm{D}_{\text {eff }}$ aqui apresentados estão, todos, na mesma ordem de grandeza que os $\mathrm{D}_{\text {eff }}$ obtidos por diferentes autores da literatura.

A Figura 51 apresenta curvas de permeabilidade representativas, obtidas para os dois aços, com e sem normalização dos dados - com este último formato se considera a influência da espessura da amostra no tempo decorrido até o estado estacionário e, também, no valor de densidade de corrente atingido. Como os valores de $\mathrm{D}_{\text {eff }}$ calculados para as amostras topo têm alta dispersão, as três curvas destas amostras são apresentadas separadamente das demais. 


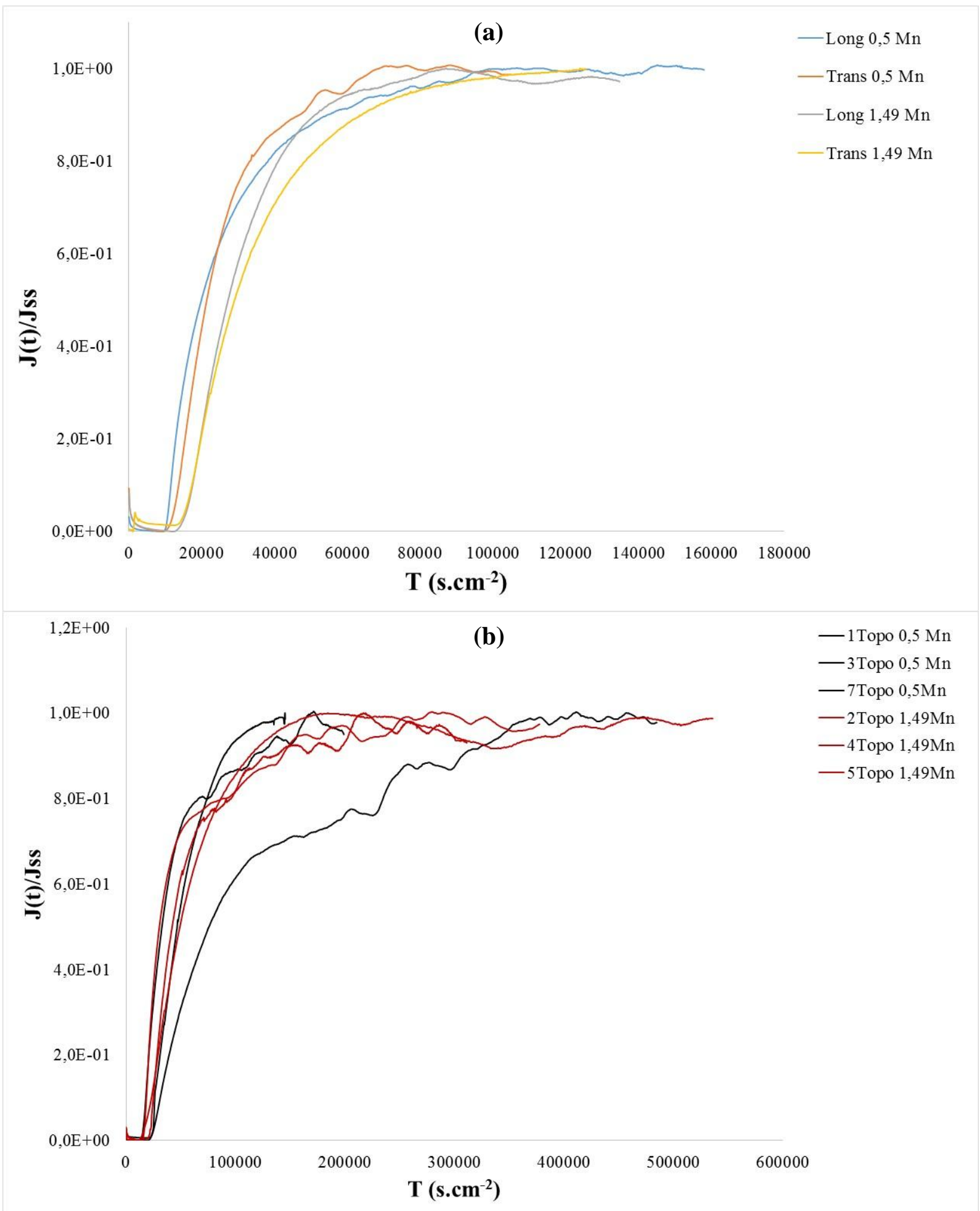

Figura 51. Curvas de permeabilidade ao $\mathrm{H}$ para amostras dos aços baixo e alto $\mathrm{Mn}$. (a) curvas normalizadas das amostras longitudinais e transversais, (b) curvas normalizadas das amostras topo, (c) curvas não normalizadas amostras longitudinais e transversais e (d) curvas não normalizadas amostras topo. 

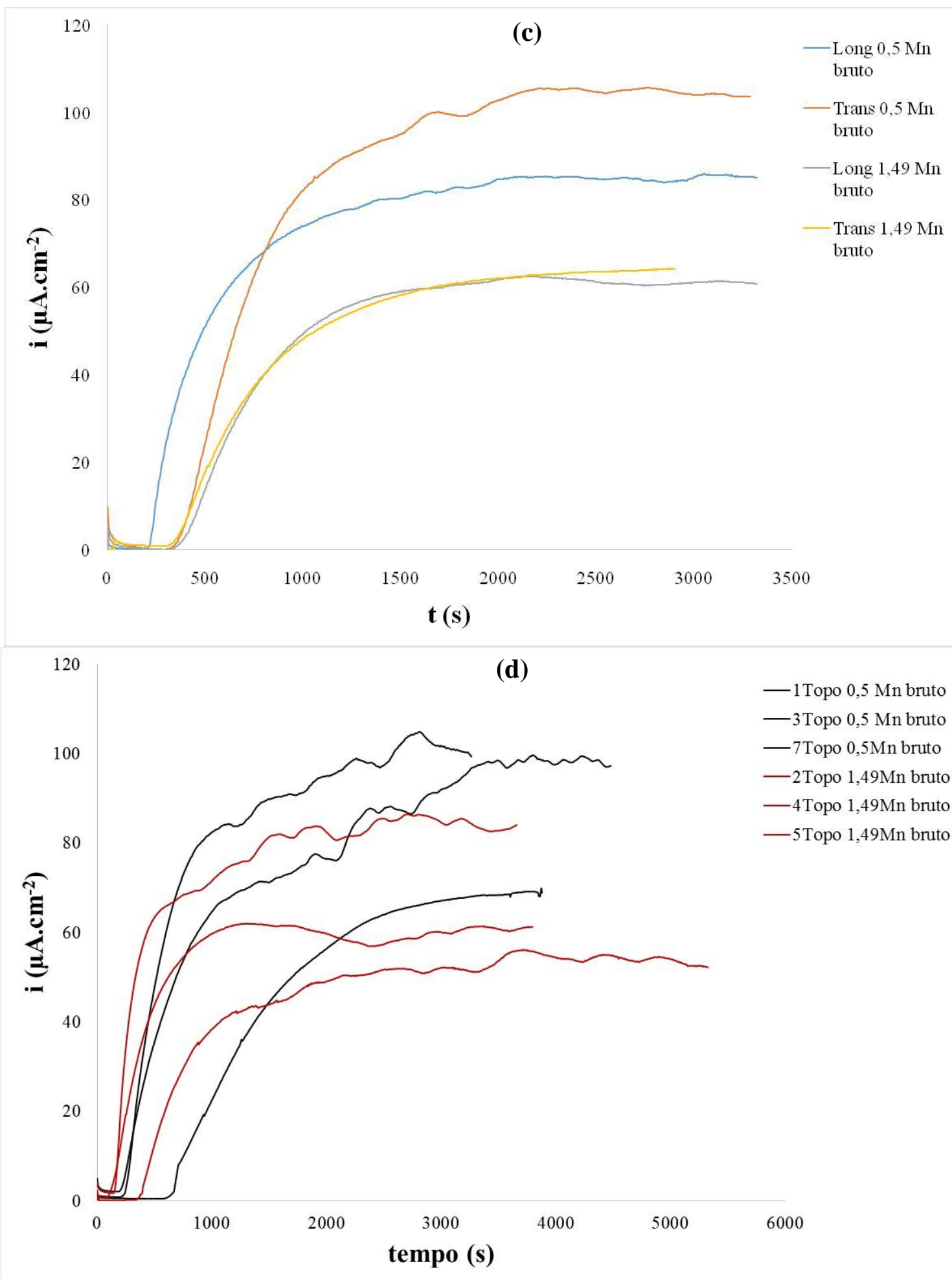

Figura 51. (Continuação) Curvas de permeabilidade ao $\mathrm{H}$ para amostras dos aços baixo e alto Mn. (a) curvas normalizadas das amostras longitudinais e transversais, (b) curvas normalizadas das amostras topo, (c) curvas não normalizadas amostras longitudinais e transversais e (d) curvas não normalizadas amostras topo. 
A região do transiente das curvas se relaciona com a entrada de $\mathrm{H}$ no material e a sua

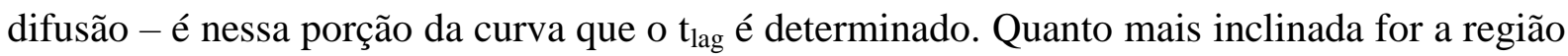
transiente, menor será o $\mathrm{t}_{\mathrm{lag}} \mathrm{e}$, portanto, maior será o coeficiente de difusão efetiva do $\mathrm{H}$ no material. A Figura 51(a) mostra as curvas normalizadas das amostras longitudinais e transversais dos dois aços. Pode-se observar que as curvas para o aço baixo $\mathrm{Mn}(0,5 \mathrm{Mn})$ praticamente coincidem entre si, assim como as do aço alto Mn (1,49 Mn); ainda, as curvas do aço baixo Mn são mais deslocadas para a esquerda do que as outras duas e são ligeiramente mais inclinadas. Essas características concordam com as informações das Tabelas 22 e 23: os valores de $\mathrm{D}_{\text {eff }} \mathrm{t}_{\text {lag }}$ para o aço baixo $\mathrm{Mn}$ tendem a ser ligeiramente mais elevados dos que os do aço alto Mn. A Figura 51(b), por sua vez, mostra as curvas de permeabilidade normalizadas para as amostras topo dos dois aços, que também ilustram os resultados das Tabelas 22 e 23: a difusão do $\mathrm{H}$ a partir dos topos das chapas é mais difícil do que nas outras duas seções, e pode atingir valores baixos ou um pouco mais altos, mas ainda inferiores aos das amostras longitudinais e transversais. Também é possível notar que, o trecho onde a curva muda do transiente para o estado estacionário, é bastante irregular para as amostras topo dos dois aços, em comparação com os outros dois tipos. Isso também indica a presença de mais obstáculos à movimentação dos átomos de $\mathrm{H}$.

As curvas das Figuras 51(c) e 51(d) refletem o mesmo comportamento descrito para as curvas das Figuras 51(a) e 51(b), porém, nas primeiras, ou seja, nas curvas não-normalizadas, nota-se a influência da espessura das amostras. Por exemplo, a amostra longitudinal do aço baixo Mn, mostrada pela Figura 51(c) tem espessura de $0,145 \mathrm{~cm}$, enquanto que a amostra tranversal para o mesmo aço e apresentada pela mesma Figura, tem espessura de 0,180 cm. A amostra transversal, mais espessa, levou mais tempo para atingir o estado estacionário e atingiu maiores valores de densidade de corrente do que a longitudinal, devido à maior quantidade de aço que os átomos de $\mathrm{H}$ tinham para percorrer.

A Figura 52 mostra graficamente os valores de $\mathrm{D}_{\text {eff }} \mathrm{t}_{\text {lag }}$ para cada tipo de amostra dos dois aços, de modo a facilitar a visualização dos resultados das Tabelas 22 e 23. 


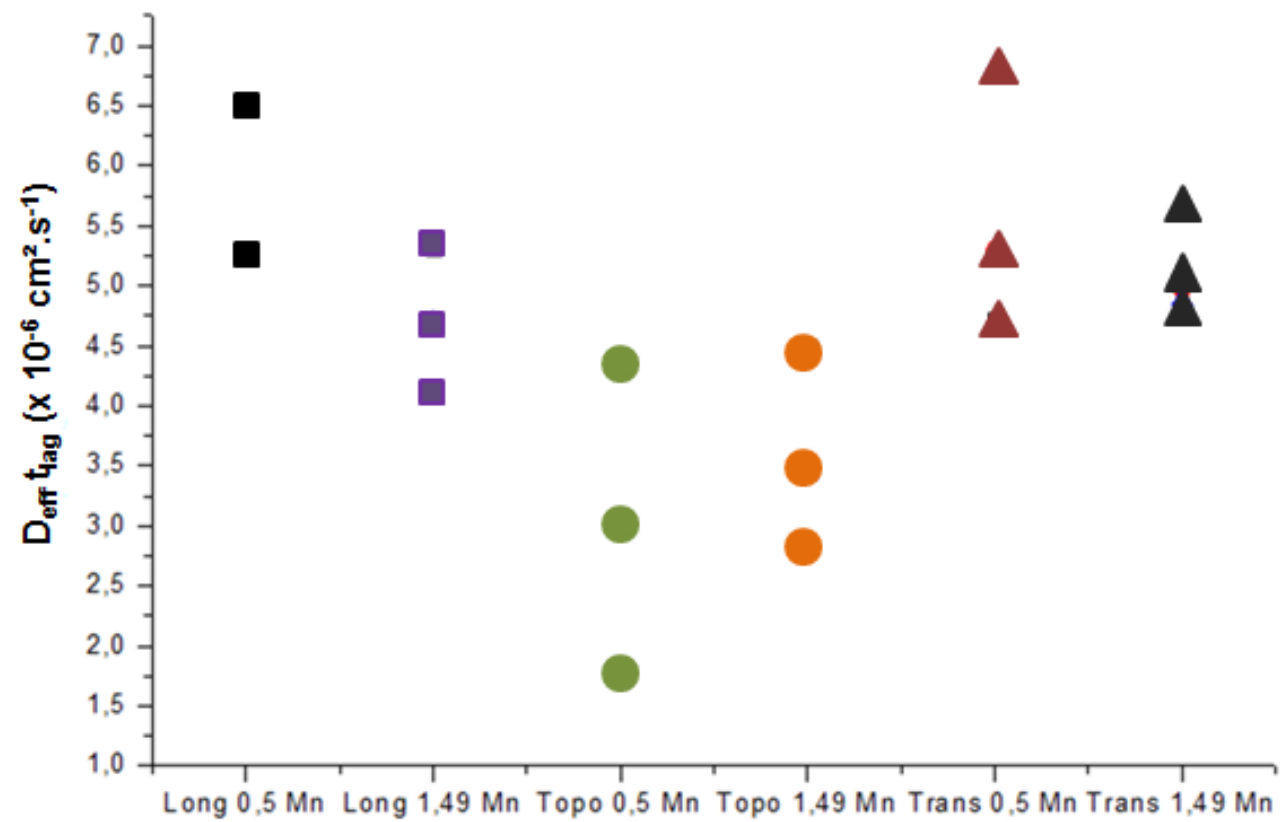

Figura 52. Comparação entre os valores de coeficiente de difusão efetiva calculados pelo método do $t_{\text {lag }}\left(D_{\text {eff }} t_{\text {lag }}\right)$ para os dois aços.

As Tabelas 24 e 25 apresentam os valores de concentração de H na subsuperfície do aço $\left(\mathrm{C}_{0}\right)$ e do número de sítios de aprisionamento por unidade de volume $\left(\mathrm{N}_{\mathrm{t}}\right)$ para os aços baixo e alto $\mathrm{Mn}$, respectivamente, junto dos valores de fluxo no estado estacionário $\left(\mathrm{J}_{\infty}\right)$ e $\mathrm{D}_{\text {eff }}$ $\mathrm{t}_{\text {lag }}$ usados para calculá-los (Equações 3 e 5). O valor do coeficiente de difusão de rede do hidrogênio na ferrita pura, a temperatura ambiente, adotado foi $D_{1}=7,2 \times 10^{-5} \mathrm{~cm}^{2} / \mathrm{s}[32]$.

Tabela 24. Valores de concentração de $\mathrm{H}$ na subsuperfície do aço $\left(\mathrm{C}_{0}\right)$ e de número de sítios de aprisionamento $\left(\mathrm{N}_{\mathrm{T}}\right)$ calculados para o aço baixo $\mathrm{Mn}$. Também são apresentados os valores de coeficiente de difusão efetiva do hidrogênio, obtidos pelo método do time-lag e de fluxo de H no estado estacionário, utilizados para os cálculos.

\begin{tabular}{|c|c|c|c|c|}
\hline \multicolumn{5}{|c|}{ Aço Baixo Mn (0,5 Mn) } \\
\hline & $\begin{array}{r}D_{\text {eff }} \mathbf{t}_{\text {lag }} \\
\left(\mathrm{cm}^{2} \cdot \mathbf{s}^{-1}\right)\end{array}$ & $\begin{array}{c}J_{\infty} \\
\left(\mathbf{m o l} \cdot \mathrm{cm}^{-2} \cdot \mathrm{s}^{-1}\right)\end{array}$ & $\begin{array}{c}\mathrm{C}_{0} \times 10^{19} \\
(\text { átomos.cm } \\
\text {-3) }\end{array}$ & $\begin{array}{c}\mathrm{N}_{\mathrm{T}} \times \mathbf{1 0}^{19} \\
(\text { sítios.cm } \\
\end{array}$ \\
\hline \multirow{2}{*}{ Longitudinal } & $6,6 \times 10^{-6}$ & $1,1 \times 10^{-9}$ & 1,5 & 5,0 \\
\hline & $5,2 \times 10^{-6}$ & $1,3 \times 10^{-9}$ & 1,9 & 8,0 \\
\hline \multirow{3}{*}{ Transversal } & $4,7 \times 10^{-6}$ & $1,8 \times 10^{-9}$ & 2,3 & 11,0 \\
\hline & $5,3 \times 10^{-6}$ & $1,8 \times 10^{-9}$ & 2,4 & 10,0 \\
\hline & $6,8 \times 10^{-6}$ & $1,4 \times 10^{-9}$ & 2,2 & 7,0 \\
\hline \multirow{3}{*}{ Topo } & $4,4 \times 10^{-6}$ & $1,4 \times 10^{-9}$ & 2,4 & 13,0 \\
\hline & $1,8 \times 10^{-6}$ & $1,3 \times 10^{-9}$ & 4,3 & 57,0 \\
\hline & $3,0 \times 10^{-6}$ & $9,2 \times 10^{-10}$ & 2,9 & 22,0 \\
\hline
\end{tabular}


Tabela 25. Valores de concentração de $H$ na subsuperfície do aço $\left(\mathrm{C}_{0}\right)$ e de número de sítios de aprisionamento $\left(\mathrm{N}_{\mathrm{T}}\right)$ calculados para o aço alto Mn. Também são apresentados os valores de coeficiente de difusão efetiva do hidrogênio, obtidos pelo método do time-lag e de fluxo de H no estado estacionário, utilizados para os cálculos.

\begin{tabular}{|c|c|c|c|c|}
\hline \multicolumn{5}{|c|}{ Aço Alto Mn (1,49 Mn) } \\
\hline & $\begin{array}{c}D_{\text {eff }} t_{\text {lag }} \\
\left(\mathrm{cm}^{2} \cdot \mathbf{s}^{-1}\right)\end{array}$ & 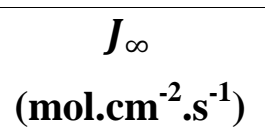 & $\begin{array}{c}\mathrm{C}_{0} \times 10^{19} \\
(\text { átomos.cm } \\
\text {-3 })\end{array}$ & $\begin{array}{c}\mathrm{N}_{\mathrm{T}} \mathrm{X} \mathbf{1 0}^{20} \\
(\text { sítios.cm } \\
\text {-3) }\end{array}$ \\
\hline \multirow{3}{*}{ Longitudinal } & $5,3 \times 10^{-6}$ & $8,3 \times 10^{-10}$ & 1,5 & 6,0 \\
\hline & $4,1 \times 10^{-6}$ & $8,8 \times 10^{-10}$ & 1,8 & 10,0 \\
\hline & $4,7 \times 10^{-6}$ & $8,0 \times 10^{-10}$ & 1,7 & 8,0 \\
\hline \multirow{3}{*}{ Transversal } & $5,6 \times 10^{-6}$ & $6,7 \times 10^{-10}$ & 1,2 & 4,5 \\
\hline & $4,9 \times 10^{-6}$ & $6,7 \times 10^{-10}$ & 1,3 & 6,0 \\
\hline & $4,8 \times 10^{-6}$ & $8,5 \times 10^{-10}$ & 1,6 & 7,0 \\
\hline \multirow{3}{*}{ Topo } & $4,5 \times 10^{-6}$ & $1,1 \times 10^{-9}$ & 1,5 & 7,0 \\
\hline & $2,8 \times 10^{-6}$ & $8,1 \times 10^{-10}$ & 1,5 & 12,0 \\
\hline & $3,4 \times 10^{-6}$ & $7,4 \times 10^{-10}$ & 1,7 & 11,0 \\
\hline
\end{tabular}

Os valores obtidos de $\mathrm{C}_{0}$ e $\mathrm{N}_{\mathrm{T}}$ são compatíveis com os encontrados na literatura, possuindo mesma ordem de grandeza [29, 31, 32, 57].

Com base nas Tabelas 24 e 25 é possível observar uma correlação geral, já esperada, entre coeficiente de difusão, concentração de $\mathrm{H}$ no metal e número de traps por unidade de volume: quanto menor o coeficiente de difusão efetiva do H no material, maiores são os outros dois parâmetros. O baixo coeficiente de difusão indica que os átomos de $\mathrm{H}$ estão com mobilidade mais baixa e isso acontece devido a presença dos traps, aos quais os átomos de $\mathrm{H}$ são aprisionados.

As Figuras 53 e 54 apresentam graficamente os valores de $\mathrm{C}_{0}$ e $\mathrm{N}_{\mathrm{t}}$ calculados para os dois aços. 


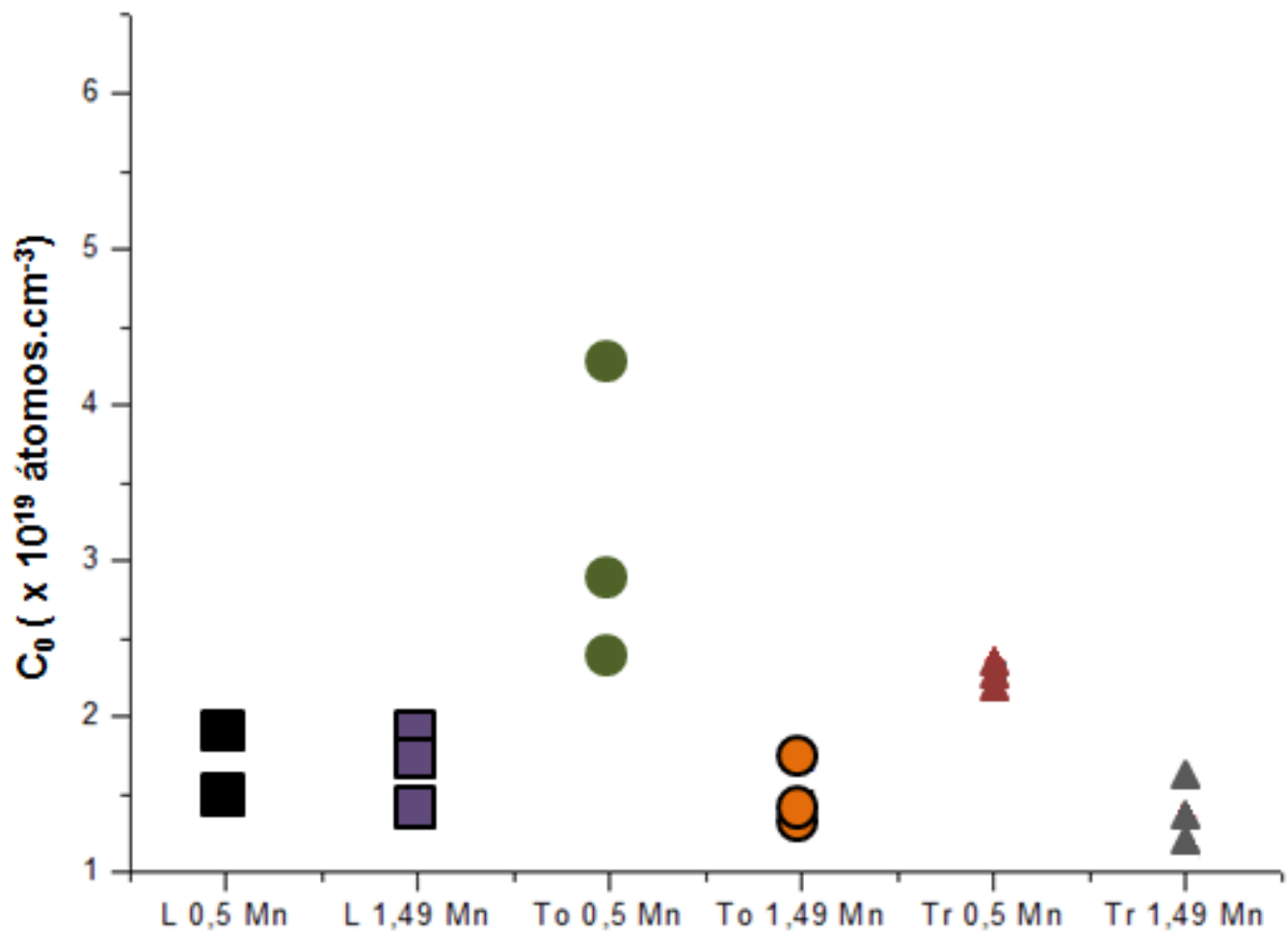

Figura 53. Comparação entre os valores de concentração de $H$ na subsuperfície do aço $\left(\mathrm{C}_{0}\right)$ calculados para os dois aços.

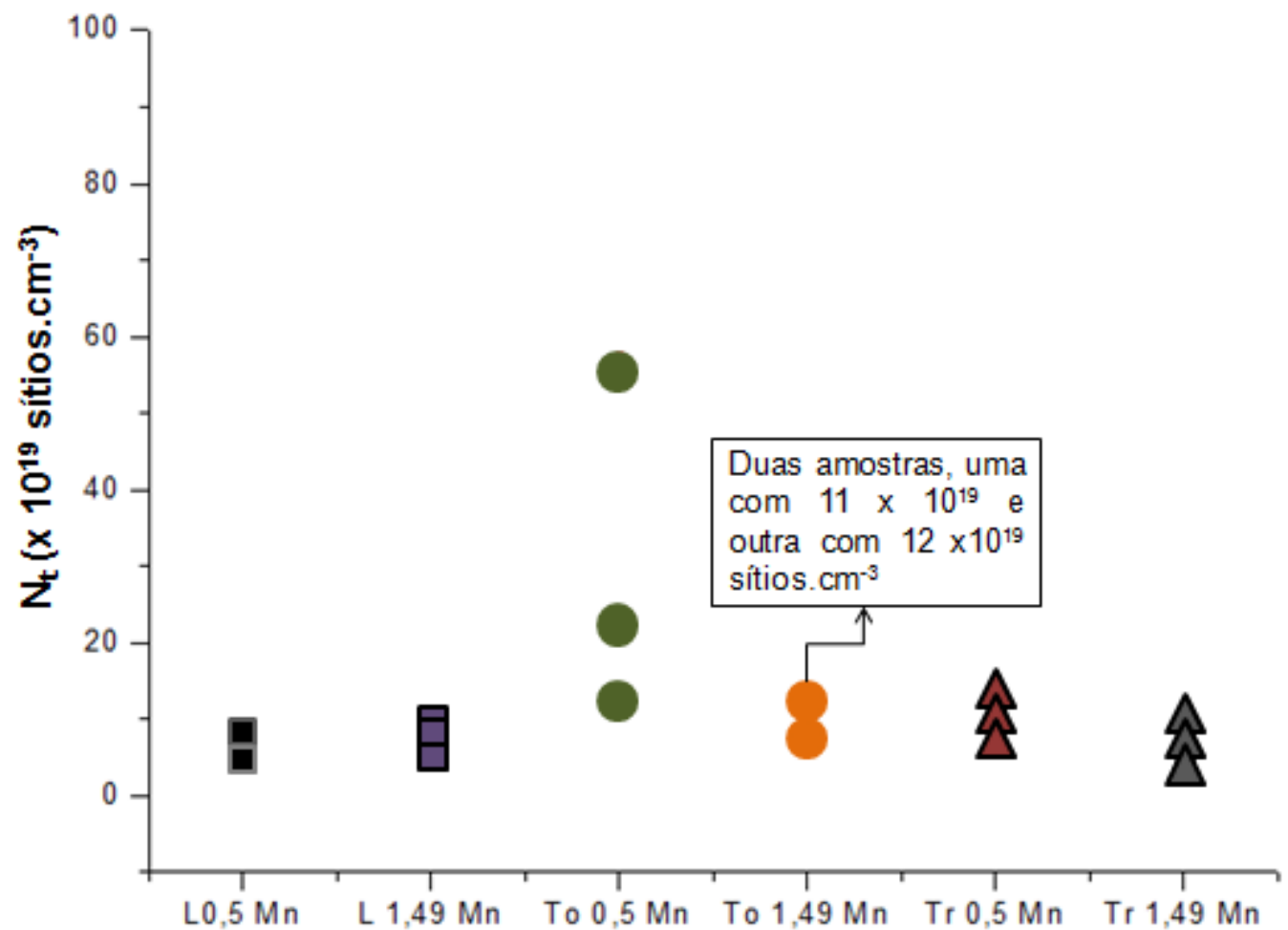

Figura 54. Comparação entre os números de sítios de aprisionamento de hidrogênio por unidade de volume $\left(\mathrm{N}_{\mathrm{t}}\right)$ calculados para os dois aços. 
Na Figura 53, analisando somente o aço baixo Mn, observa-se que as amostras transversais têm valores de $\mathrm{C}_{0}$ ligeiramente superiores das longitudinais, o que pode ser considerado um reflexo do fluxo de $\mathrm{H}$ nestas amostras. Ainda avaliando somente o aço baixo $\mathrm{Mn}$, as amostras do topo com $\mathrm{D}_{\text {eff }}$ inferiores apresentaram $\mathrm{C}_{0}$ mais elevados. Já as amostras do aço alto $\mathrm{Mn}$ apresentaram valores de $\mathrm{C}_{0}$ mais próximos entre si e, de modo geral, um pouco mais baixos do que as amostras do outro aço. O fluxo de $\mathrm{H}$ no aço alto $\mathrm{Mn}$ é uma ordem de grandeza menor do que no aço baixo Mn.

$\mathrm{O}$ comportamento observado através da Figura 54 para o número de traps, $\mathrm{N}_{\mathrm{t}}$, é parecido com o descrito para o $\mathrm{C}_{0}$. $\mathrm{O}$ mais intrigante é a comparação entre os valores de $\mathrm{N}_{\mathrm{t}}$ das amostras do topo dos dois aços. Os valores de $\mathrm{D}_{\text {eff }}$ destes tipos de amostras são iguais, o tipo de variação no $\mathrm{D}_{\text {eff }}$ para cada repetição do ensaio de permeabilidade é o mesmo; a diferença entre os valores de fluxo de $\mathrm{H}$ dessas amostras é a mesma observada para as amostras longitudinais e transversais, contudo, os valores de $\mathrm{N}_{t}$ para as amostras do topo do aço baixo Mn são consideravelmente maiores do que das amostras topo alto Mn.

\subsection{Análise de Dessorção Térmica}

Medidas de dessorção térmica foram realizadas para os dois aços. Como se trataram de medidas preliminares e como o equipamento, no período de execução dos ensaios, não estava habilitado para utilização de rampas de aquecimento, que permitiriam investigações do hidrogênio liberado por traps específicos, foi possível apenas medir o teor total de $\mathrm{H}$ aprisionado pelos aços à temperatura ambiente e liberados a $400{ }^{\circ} \mathrm{C}$. Estas medidas puderam, então, ser usadas para complementar e validar os resultados de $\mathrm{C}_{0}$ e $\mathrm{N}_{\mathrm{t}}$, que são obtidos de maneira indireta a partir do ensaio de permeabilidade ao $\mathrm{H}$.

A Figura 55 apresenta, então, os teores totais de fluxo de $\mathrm{H}$ desprendido por cada tipo de amostra estudada. Lembrando que as amostras foram carregadas por $17 \mathrm{~h}$ em solução contendo $\mathrm{H}_{2} \mathrm{SO}_{4}$ e $\mathrm{As}_{2} \mathrm{O}_{3}$ (veneno catódico), com aplicação de corrente catódica de 20 $\mathrm{mA} . \mathrm{cm}^{-2}$ e que só foi possível fazer uma medida por amostra (não foram feitas repetições). 


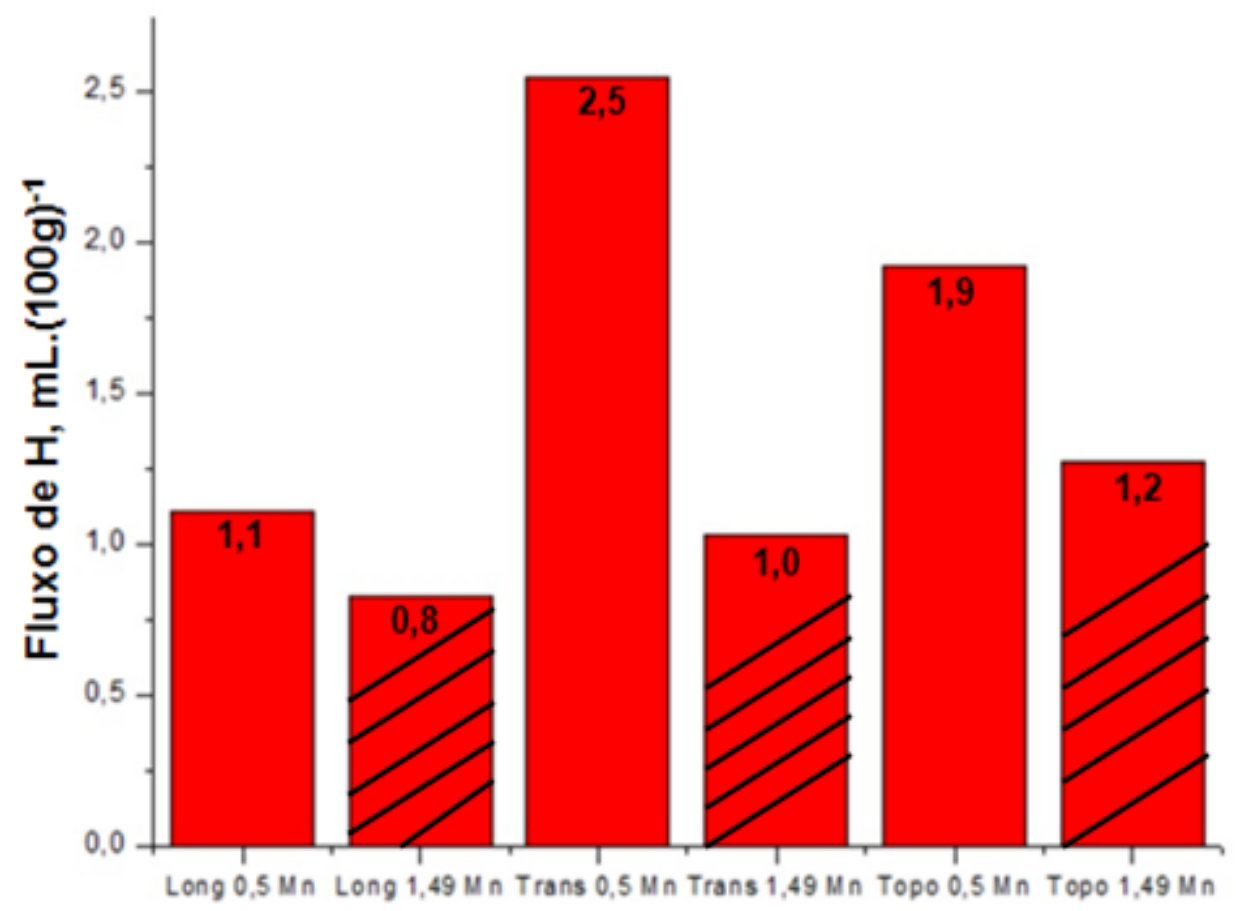

Figura 55. Valores de fluxo de $\mathrm{H}$ desprendidos pelos aços baixo Mn (vermelho) e alto Mn (hachurado) durante ensaio de dessorção térmica.

Os valores de fluxo de $\mathrm{H}$ desprendido das amostras concordam com os de $\mathrm{C}_{0}$ e de $\mathrm{N}_{\mathrm{t}}$, apesar de não ter sido possível fazer repetições desses ensaios. Observa-se que o aço baixo $\mathrm{Mn}$ aprisionou mais $\mathrm{H}$ do que o alto $\mathrm{Mn}$, e que as amostras topo e transversal do aço baixo Mn desprenderam mais $\mathrm{H}$ do que as demais. 


\section{Discussão}

A discussão foi elaborada de acordo com os três seguintes blocos: (1) primeiro, são comparados e discutidos os resultados de caracterização microestrutural e de permeabilidade ao hidrogênio dos dois aços; (2) em seguida, é feita a análise dos valores de $\mathrm{D}_{\text {eff }} \mathrm{t}_{\text {lag }}$ obtidos para as diferentes seções do aço alto Mn, com foco na presença de bandeamento e (3) por fim, são analisados os valores de $\mathrm{D}_{\text {eff }} \mathrm{t}_{\mathrm{lag}}$ para as três seções do aço baixo Mn, utilizando-se dos resultados de EBSD de textura e de comprimentos de contornos de grão de baixo, médio e alto ângulo.

\subsection{Comparação entre os dois aços: características microestruturais e resultados do ensaio de permeabilidade ao $\mathbf{H}$}

Para facilitar a discussão, a Tabela 26 resume os resultados de caracterização microestrutural apresentados ao longo da seção 5.1 para os dois aços.

Tabela 26. Principais características microestruturais dos aços baixo e alto Mn, já apresentadas na seção 5.1. do presente trabalho.

\begin{tabular}{|c|c|}
\hline Aço baixo Mn & Aço alto Mn \\
\hline $\begin{array}{l}\text { - Pequenas inclusões de formato arredondado, que } \\
\text { podem ser classificadas como do tipo D2 série } \\
\text { fina [81]; } \\
\text { - Distribuição homogênea das inclusões pela } \\
\text { microestrutura; } \\
\text { - Compostas por } \mathrm{Al}, \mathrm{O}, \mathrm{Ca} \text { e, às vezes, baixos } \\
\text { teores de } \mathrm{S} \text {. }\end{array}$ & $\begin{array}{l}\text { - Inclusões com formatos variados; } \\
\text { - Maiores dimensões que a do aço baixo Mn } \\
\text { (qualitativamente); } \\
\text { - Podem ser classificadas como do tipo D3 série fina } \\
\text { [81]; } \\
\text { - Distribuição heterogênea pela microestrutura; } \\
\text { - Inclusões aparecem mais alongadas na seção } \\
\text { longitudinal do que na transversal, devido à } \\
\text { laminação; } \\
\text { - Compostas por } \mathrm{Al}, \mathrm{O}, \mathrm{Ca}, \mathrm{Mn}, \mathrm{S} \text { e Ti. }\end{array}$ \\
\hline
\end{tabular}


Tabela 26. (Continuação) Principais características microestruturais dos aços baixo e alto Mn, já apresentadas na seção 5.1. do presente trabalho.

\begin{tabular}{|c|c|}
\hline Aço baixo Mn & Aço alto Mn \\
\hline $\begin{array}{l}\text { - Matriz de ferrita refinada, com tamanho médio de } \\
\text { grão aproximado de } 9 \mu \mathrm{m} \text {, e pequenas ilhas de } \\
\text { perlita degenerada; } \\
\text { - Distribuição homogênea das perlitas pela matriz; } \\
\text { - Baixa fração volumétrica de perlita, em torno de } \\
5 \% \text {; } \\
\text { - Microestrutura homogênea ao longo da espessura } \\
\text { e sem bandeamento; } \\
\text { - Seção longitudinal apresenta grãos ligeiramente } \\
\text { mais alongados do que a seção transversal; seção } \\
\text { do topo da chapa tem os grãos mais equiaxiais do } \\
\text { que as outras duas. }\end{array}$ & $\begin{array}{l}\text { - Microestrutura formada por bandas de ferrita e de } \\
\text { perlita; } \\
\text { - Bandas de ferrita têm grãos menos refinados que o } \\
\text { aço baixo Mn (tamanho médio de grão de } 15,3,9,0 \\
\text { e } 17,8 \text { para as seções longitudinal, transversal e } \\
\text { topo, respectivamente); } \\
\text { - As perlitas que compõem as bandas têm dimensões } \\
\text { maiores do que as ilhas de perlita do aço baixo Mn; } \\
\text { - Fração volumétrica de perlita em torno de } 13 \% \text {; } \\
\text { Microestrutura é heterogênea ao longo da } \\
\text { espessura: além das bandas, os tamanhos de grão } \\
\text { de ferrita variam consideravelmente ao longo da } \\
\text { espessura da chapa; } \\
\text { Presença de marcada linha central com segregação } \\
\text { de elementos de liga e formação de carbonetos, } \\
\text { nitretos, martensita/bainita (agregados eutetóides); } \\
\text { - Seção longitudinal com grãos muito mais } \\
\text { alongados do que os da seção transversal; grãos do } \\
\text { topo da chapa são mais equiaxiais do que os } \\
\text { demais. }\end{array}$ \\
\hline
\end{tabular}

O aço baixo Mn foi produzido recentemente para uso em meio sour, com a utilização das novas tecnologias descritas ao longo das seções 3.1, 3.2 e 3.3, enquanto que o aço alto Mn foi desenvolvido há vários anos, com técnicas menos sofisticadas e para uso em ambientes não-sour. As características microestruturais dos dois aços refletem claramente as suas diferentes rotas de processamento.

Inclusões não metálicas, junto da segregação de elementos de liga, bandeamento, porosidade e microvazios correspondem aos defeitos mais prejudiciais para a resistência aos danos provocados pelo hidrogênio [7]. Para ser usado em ambientes sour, o aço deve conter a menor fração volumétrica possível de inclusões de sulfetos e de óxidos, sendo que as 
inclusões remanescentes devem ser refinadas e ter formatos globulares, caso contrário, durante o processamento (a quente ou a frio), as inclusões são alongadas e/ou fracionadas, o que leva ao aumento da quantidade de interface inclusão/matriz e da fração volumétrica de microcavidades, formadas nesse tipo de interface [7, 27, 44]. Isso faz com que o potencial para aprisionamento de hidrogênio e fragilização aumente [27]. A redução dos teores de Mn e de $S$, junto de tratamentos com Ca metálico para arredondamento das inclusões, consistem em métodos cruciais para eliminação das inclusões alongadas de $\mathrm{MnS}$. O aço baixo Mn passou por estes processos e, como pode-se ver pela Tabela 26, suas inclusões têm as características necessárias para o bom desempenho em meios sour [7]. O aço alto Mn também passou por tratamento com $\mathrm{Ca}$, porém a sua eficiência foi inferior, uma vez que nele foram encontradas algumas inclusões alongadas e fracionadas (Figuras 31(d) e 32 (a)).

A ausência de bandas de segregação no aço baixo Mn, junto de outras características favoráveis ao bom desempenho em meios sour, listadas na Tabela 26, é resultante da redução do teor de Mn, entre outros elementos com tendência à segregação, e do uso de soft reduction durante a fabricação da placa. Bandas de segregação, em particular a banda central de segregação, com inclusões alongadas e interfaces de ferrita, perlita e microconstituinte MA, constituem locais preferenciais para a nucleação e propagação de trincas induzidas por $\mathrm{H}$. Interfaces de microconstituintes de alta dureza atuam como caminhos preferenciais para a propagação de trincas, enquanto que uma matriz ferrítica é mais dúctil e, mesmo que nela seja gerada uma microtrinca, a sua propagação dificilmente ocorrerá: a matriz ferrítica é capaz de absorver a energia de deformação gerada pela trinca recém-nucleada, impedindo a sua propagação [6, 7, 16, 19, 27]. Assim, com base na discussão sobre a microestrutura dos dois aços, pode-se dizer que o aço baixo Mn aparenta ter melhor resistência aos danos por $\mathrm{H}$ do que o aço alto $\mathrm{Mn}$ - para confirmar esta tendência seria necessário fazer ensaios de resistência ao trincamento induzido por $\mathrm{H}$, por exemplo.

Um dos objetivos estabelecidos no início do mestrado foi comparar as difusividades do H no aço baixo Mn e no aço alto Mn. Esperava-se que o coeficiente de difusão efetiva obtido para o primeiro fosse muito mais alto do que para o segundo, devido à suposta menor quantidade de traps do aço baixo Mn atuando como obstáculos ao movimento dos átomos de H. No entanto, os resultados apresentados pelas Tabelas 22, 23 e a comparação feita através da Figura 52 contrariam as expectativas iniciais: os valores de $D_{\text {eff }} t_{\text {lag }}$ para as seções longitudinais e transversais do aço baixo Mn são apenas ligeiramente superiores aos dessas mesmas seções no aço alto Mn (Figura 51(a), Figura 52). Para explicar este comportamento é 
preciso, antes, identificar os tipos de traps que puderam ser observados nos dois aços, que aparecem listados pela Tabela 27.

Tabela 27. Tipos de traps identificados nos dois aços através de microscopia óptica e eletrônica de varredura.

\begin{tabular}{|c|c|}
\hline Aço baixo Mn & Aço alto Mn \\
\hline Contornos de grão de ferrita & Contornos de grão de ferrita \\
\hline $\begin{array}{c}\text { Interfaces ferrita/cementita, derivadas das } \\
\text { pequenas ilhas de perlita degenerada }\end{array}$ & $\begin{array}{c}\text { Interfaces ferrita/cementita, provenientes das } \\
\text { placas de perlita bandeadas }\end{array}$ \\
\hline Inclusões de $\mathrm{Al}, \mathrm{Ca}, \mathrm{O}$ e S & Inclusões $\mathrm{Al}, \mathrm{Ca}, \mathrm{O}, \mathrm{S}$ e Mn \\
\hline- & Microconstituintes aciculares presentes nas \\
& bandas centrais da chapa \\
\hline- & Carbonetos de Nb e nitretos de Ti, também \\
& presentes nas linhas centrais da chapa \\
\hline
\end{tabular}

Os contornos de grão de ferrita, como já discutido na seção 3.5.4, são traps reversíveis de $\mathrm{H}$ e, de acordo com [50], apresentam energia de ligação com o $\mathrm{H}\left(\mathrm{E}_{\mathrm{b}}\right)$ de 9,6 kJ.mol${ }^{-1}$ e energia de ativação para aprisionamento/desaprisionamento de $\mathrm{H}\left(\mathrm{E}_{\mathrm{at}}\right)$, em módulo, de 17,2 $\mathrm{kJ} \mathrm{mol}^{-1}$. As interfaces ferrita/cementita também são consideradas traps reversíveis, pois apresentam baixos valores de $\mathrm{E}_{\mathrm{b}}$ e de $\mathrm{E}_{\mathrm{aT}}$, entre 8,40 a $15,70 \mathrm{~kJ}^{\mathrm{mol}} \mathrm{m}^{-1}[52,53]$ e $18,35 \mathrm{~kJ} \mathrm{~mol}^{-1}$ [44], respectivamente; na verdade, os valores de energias de ligação e ativação para este segundo tipo de interface são próximos dos contornos de grão ferríticos. Logo, pensando apenas nos valores de energia dados, sem levar em conta a distribuição das interfaces, formato e seu alongamento, é possível dizer que as interfaces ferrita/cementita e os contornos de grão ferríticos interagem de maneiras semelhantes com o $\mathrm{H}$ e influenciam de modo parecido a difusão do $\mathrm{H}$ - é como se, ao comparar os dois aços, o $\mathrm{H}$ enxergasse a interface ferrita/cemenetita como um contorno de grão ferrítico e vice-versa.

A Tabela 19 apresenta valores de $S_{\mathrm{v}}$ parecidos para os aços baixo e alto Mn. Estas quantidades de interface foram medidas do seguinte modo (método já apresentado na seção 4.2.3.3.): primeiro, se fez a contagem dos grãos de ferrita com contornos de alto ângulo que interceptavam a linha teste - estes são os tipos de contornos distinguíveis a olho nu, uma vez que não foi utilizado analisador de imagens nessa etapa - depois, fez-se o cálculo de $\mathrm{N}_{\mathrm{L}}$ (número de grãos por unidade de comprimento $(\mathrm{mm})$ ) e, por fim, para as amostras do aço baixo Mn multiplicou-se o valor de $\mathrm{N}_{\mathrm{L}}$ por 2 e para o aço alto $\mathrm{Mn}$ o valor de $\mathrm{N}_{\mathrm{L}}$ foi multiplicado por 4, para considerar a presença das perlitas (Equações 15 e 16, 
respectivamente). Este método é descrito pela norma ASTM E112-13 [87] e seus resultados devem ser lidos como uma aproximação bastante simplificada, principalmente para o aço alto Mn. O aço alto Mn contém em torno de $13 \%$ de fração volumétrica de perlita, que forma bandas ao longo da espessura do aço, e em grandes aumentos, a partir de 5000 x no MEV, são identificadas como colônias de perlita fina. A Figura 56 contém micrografia de elétrons secundários de uma das colônias de perlita presentes em amostra longitudinal do aço alto Mn.

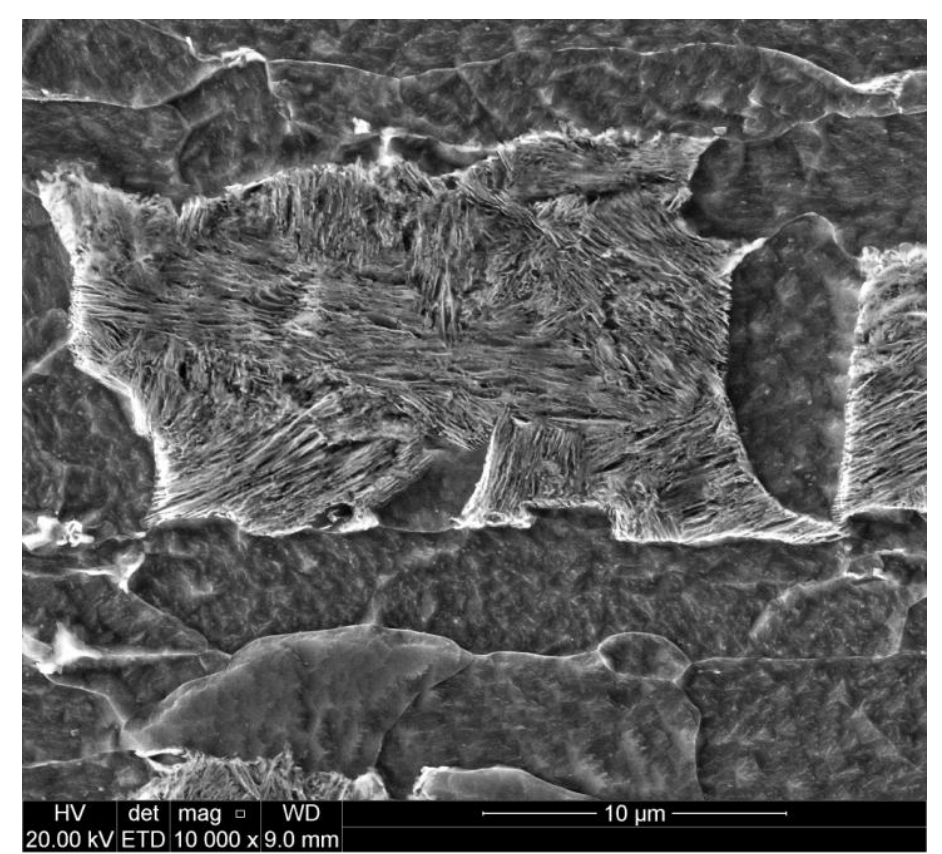

Figura 56. Micrografia de elétrons secundários mostrando colônia de perlita fina presente em amostra longitudinal do aço alto Mn. Ataque: Nital 2\%; Aumento: 10000x.

As finas lamelas da perlita fornecem quantidade de interface ferrita/cementita que não foi contabilizada no cálculo de $S_{\mathrm{v}}$ do aço alto $\mathrm{Mn}$ e que, se forem contadas, com certeza tornarão o valor de $S_{v}$ deste aço maior. O aço baixo $M n$, por sua vez, possui grãos de ferrita mais refinados do que o outro e, por esta razão, apresenta maior quantidade de contornos ferríticos do que o aço alto $\mathrm{Mn}$ (multiplicando o $\mathrm{N}_{\mathrm{L}}$ do segundo aço por 2, em vez de 4, o valor obtido é mais baixo do que o $S_{\mathrm{v}}$ do baixo $M n$ ). Já a fração volumétrica de perlita do aço baixo Mn é mais baixa, em torno de 5\%, e suas dimensões são menores do que as do aço alto Mn e, assim, sua contribuição para o $S_{v}$ é menor (as interfaces ferrita/cementita do aço baixo Mn também não entraram no cálculo de $S_{\mathrm{v}}$ ). Ao se analisar todas as contribuições de interfaces ferrita/cementita e ferrita/ferrita, pode-se dizer que o aço alto $\mathrm{Mn}$ tem maior quantidade destes tipos de interface de baixa energia de ligação $\mathrm{E}_{\mathrm{b}}$ do que o baixo $\mathrm{Mn}$.

As inclusões presentes nos dois aços, apesar das diferenças morfológicas já apresentadas pela Tabela 26 e discutidas na presente seção e ao longo da seção 5.1., podem 
ser consideradas como de mesma natureza e, para a análise da difusão do $\mathrm{H}$, as suas morfologias não têm grande influência. As morfologias de inclusões têm papel mais importante ao se avaliar os resultados de ensaios de resistência ao trincamento induzido por H, por exemplo, que envolvem mecanismos de propagação de trincas e fratura. As frações volumétricas de inclusões em cada aço são informações mais interessantes para a análise de difusividade do $\mathrm{H}$ nos aços, porém, não foram realizadas.

$\mathrm{O}$ aço alto Mn apresenta outros tipos de traps que o aço baixo Mn não possui: microconstituintes aciculares, carbonetos micrométricos e facetados de $\mathrm{Nb}$ e nitretos de $\mathrm{Ti}$, todos localizados nas bandas centrais da chapa. Os carbonetos facetados de $\mathrm{Nb}$ e nitretos de Ti estão presentes, qualitativamente, em baixas frações volumétricas e, por este motivo, o efeito dos mesmos na difusão do $\mathrm{H}$ não parece ser pronunciado. Os microconstituintes aciculares, apesar de restritos à banda central da chapa, fornecem quantidade de interface mais relevante para dificultar a movimentação dos átomos de $\mathrm{H}$ do que os carbonetos e nitretos mencionados. Ainda, estas interfaces de microconstituintes têm energias de ligação com o H mais elevadas do que os contornos de grão ferríticos e as interfaces ferrita/cementita (Tabela 4).

Então, após essa análise dos traps presentes nos dois aços, pode-se concluir que o aço alto $\mathrm{Mn}$, além de apresentar maior quantidade de interface de baixa energia de ligação com o $\mathrm{H}$ do que o aço baixo Mn (balanço entre as interfaces ferrita/ferrita e ferrita/cementita dos dois aços), possui um adicional de interfaces de microconstituintes de elevada dureza, que não são encontrados no aço baixo Mn. Assim, considera-se que a quantidade de interface seja maior no volume total do aço alto Mn, não apenas nas superfícies de entrada de H. Isso justifica os menores valores de $\mathrm{D}_{\text {eff }} \mathrm{t}_{\text {lag }}$ do $\mathrm{H}$ no aço alto $\mathrm{Mn}$, em comparação com o aço baixo $\mathrm{Mn}$.

Os outros dois parâmetros que foram calculados a partir dos ensaios de permeabilidade são o $\mathrm{C}_{0}$ e o $\mathrm{N}_{\mathrm{t}}$ e espera-se que eles variem de modo inversamente proporcional ao $\mathrm{D}_{\text {eff, }}$ como se pode ver pelas Equações 3 e 5: quanto maior o valor de $D_{\text {eff }}$, menores os valores de $\mathrm{N}_{\mathrm{t}}$ e de $\mathrm{C}_{0}$. Essa relação é bastante coerente, uma vez que a presença de traps dificulta a difusão do $\mathrm{H}$ e, quanto maior a quantidade de traps na microestrutura, maior a concentração de $\mathrm{H}$ aprisionado. Contudo, as Figuras 53 e 54 mostram que os valores de $\mathrm{N}_{\mathrm{t}}$ e de $\mathrm{C}_{0}$ do aço baixo Mn são iguais ou superiores, dependendo da seção analisada, aos do aço alto $\mathrm{Mn}$, contrariando as expectativas. Os resultados de dessorção térmica apresentados pela Figura 55, mesmo precisando de repetições para aumento de sua confiabilidade, concordam com a 
tendência mostrada pelas Tabelas 24 e 25 e Figuras 53 e 54: o aço baixo Mn aprisiona mais H do que o alto Mn.

Existem duas hipóteses que podem explicar a pouca diferença entre os $\mathrm{D}_{\text {eff }}$ dos dois aços e os resultados de $\mathrm{N}_{\mathrm{t}}$ e de $\mathrm{C}_{0}$ : (1) a fração volumétrica de inclusões do aço baixo Mn é mais elevada do que a do aço alto Mn e (2) o aço baixo Mn contém maior fração volumétrica de nanoprecipitados de microadições de liga, em especial de nanocarbonetos de $\mathrm{Nb}$ do que o aço alto Mn, compensando as contribuições das perlitas neste último.

A hipótese 1 não envolve discussões muito profundas: o aço baixo Mn pode ter sido produzido com maior fração volumétrica de inclusões refinadas e arredondadas de Al, Ca e O do que o aço alto Mn. As pequenas inclusões esféricas, poderiam, inclusive, auxiliar a diminuir a suscetibilidade do aço aos danos por $\mathrm{H}$ - através do aprisionamento, diminuem a quantidade de $\mathrm{H}$ difusível e de $\mathrm{H}$ ligado a traps reversíveis, ou seja, os que são considerados mais prejudiciais para as propriedades mecânicas dos aços. No entanto, esta hipótese tem um problema relacionado com os resultados de dessorção térmica. Nestes ensaios, as amostras foram aquecidas a $400{ }^{\circ} \mathrm{C}$ e, nesta temperatura, o aço baixo $\mathrm{Mn}$ liberou mais $\mathrm{H}$ do que o aço alto Mn. De acordo com [44], como já mostrado na seção 3.5.1., o pico associado à liberação de $\mathrm{H}$ de inclusões contendo $\mathrm{Al}$ e $\mathrm{O}$ ocorre a $580{ }^{\circ} \mathrm{C}$ e, portanto, os fluxos apresentados pela Figura 55 não podem ter sido parcialmente originados da liberação de $\mathrm{H}$ a partir de inclusões.

A hipótese 2, então, se torna a maior aposta para explicar os resultados de permeabilidade ao H. Sabe-se que as microadições são adicionadas nos aços microligados para melhorar a resistência mecânica dos mesmos, tanto pelo mecanismo de endurecimento por precipitação, como através do refino de grão - durante o TMCR, os nanoprecipitados de microadições ancoram os contornos de grão da austenita, impedindo que cresçam durante a recristalização e garantindo que a microestrutura final ferrítica seja altamente refinada. Como o próprio nome sugere, todo aço microligado apresenta microadições. Logo, os dois aços, alto e baixo Mn, contém microadições de elementos de liga. Abaixo é reproduzida a Tabela 7, renomeada de Tabela 28, que contém as composições químicas dos dois materiais.

Tabela 28. Composições químicas dos aços HSLA API grau X65 estudados.

\begin{tabular}{|c|c|c|c|c|c|c|c|c|c|c|c|c|}
\hline Aço & $\mathbf{C}$ & $\mathbf{S i}$ & $\mathbf{M n}$ & $\mathbf{P}$ & $\mathbf{S}$ & $\mathbf{C r}$ & $\mathbf{N i}$ & $\mathbf{A l}_{\text {total }}$ & $\mathbf{C u}$ & $\mathbf{N b}$ & $\mathbf{T i}$ & $\mathbf{N}$ \\
\hline Baixo Mn & 0,038 & 0,223 & 0,533 & 0,007 & 0,0011 & 0,441 & 0,139 & 0,023 & 0,267 & 0,089 & 0,011 & 0,0048 \\
\hline Alto Mn & 0,095 & 0,230 & 1,490 & 0,018 & 0,002 & - & - & 0,044 & - & 0,048 & $0,015^{* *}$ & 0,005 \\
\hline
\end{tabular}


Como se pode ver pela Tabela 28, os dois aços apresentam teores parecidos de Ti e o aço baixo Mn possui, aproximadamente, o dobro do teor de $\mathrm{Nb}$ do aço alto $\mathrm{Mn}$.

Uma das abordagens mais recentes para se melhorar a resistência aos danos por $\mathrm{H}$, principalmente de aços com graus API 5L mais elevados, é utilizar nanoprecipitados de microadições de liga, distribuídos de maneira homogênea pelo volume do material, para aprisionar irreversívelmente os átomos de H (mesmo papel das inclusões esféricas e finas). Todavia, não são todos os tipos de precipitados que conseguem influenciar de maneira positiva a resistência à fragilização por $\mathrm{H}$. De acordo com [56] existem três requisitos básicos que um trap irreversível deve possuir para aprisionar $\mathrm{H}$ de maneira favorável às propriedades mecânicas de um aço: (1) alta capacidade de aprisionamento de H, para atração de quantidades suficientemente grandes de átomos de H; (2) interação moderada com os átomos de H e (3) não ser um concentrador de tensão. A energia de ligação do trap deve ser forte o suficiente para que o átomo de $\mathrm{H}$ aprisionado não escape e volte a se difundir pela rede e, ao mesmo tempo, a energia não pode ser muito alta, pois pode fazer com que o sítio sature muito rapidamente. O mais desejável é que o trap se comporte como um capacitor: que absorva o $\mathrm{H}$ rapidamente e o liberte vagarosamente [56].

Muitos estudos sobre o potencial do TiC como trap irreversível já foram realizados [44, 66, 97 e 98] e, com exceção de [66], indicaram que este tipo de carboneto, quando incoerente, não é capaz de aprisionar átomos de $\mathrm{H}$ à temperatura ambiente. A energia de ativação (o $\mathrm{E}_{\mathrm{s}}$ da Figura 10) necessária para um átomo de $\mathrm{H}$ migrar de um sítio da rede cristalina para o TiC incoerente é tão alta que o fenômeno só é capaz de ocorrer em temperaturas elevadas [44, 53, 55, 56, 97, 98]. Depover e Verbeken [66], no entanto, encontraram efeitos benéficos para a resistência à fragilização por $\mathrm{H}$ associados à presença de TiC. Outros tipos de carbonetos e precipitados nanométricos vêm sendo estudados e considerados para essa aplicação de melhorar a resistência aos danos por $\mathrm{H}$, como o $\mathrm{NbC}$ e precipitados ricos em $\mathrm{Cu}[36]$.

$\mathrm{O} \mathrm{NbC}$ semicoerente tem maior capacidade para aprisionar $\mathrm{H}$ do que o $\mathrm{TiC}$ e o $\mathrm{VC}$ semicoerentes, e é uma das grandes promessas para melhora de propriedades dos aços [56, 57]. De acordo com [56], o pico de dessorção associado ao NbC semicoerente se dá em torno de $212{ }^{\circ} \mathrm{C}$ e o do $\mathrm{TiC}$ semicoerente, em $150{ }^{\circ} \mathrm{C}$ e, ainda, para frações volumétricas iguais destes carbonetos semicoerentes, o NbC aprisiona mais $\mathrm{H}$ do que o TiC [56]. Wallaert et.al. [57] encontraram que o $\mathrm{H}$ aprisionado por $\mathrm{NbC}$ de pequenas dimensões, carregados com $\mathrm{H}$ por via eletrolítica à temperatura ambiente, têm picos de dessorção em torno de $250{ }^{\circ} \mathrm{C}$ [57]. 
Tendo em mente que os dois aços estudados no presente mestrado apresentam mais $\mathrm{Nb}$ do que Ti em sua composição, que o teor de Ti é praticamente o mesmo nos dois, que o aço baixo $\mathrm{Mn}$ tem o dobro de $\mathrm{Nb}$ do aço alto $\mathrm{Mn}$, e as temperaturas dos picos de dessorção informadas no parágrafo anterior, a hipótese 2 ganha mais força: os responsáveis pelos valores de $\mathrm{N}_{\mathrm{t}}$ e $\mathrm{C}_{0}$ do aço baixo $\mathrm{Mn}$ podem ser, sim, os $\mathrm{NbC}$ - no caso, semicoerentes com a matriz ferrítica. Os aços baixo e alto Mn podem conter, também, TiC coerentes ou semicoerentes, porém, dada a composição química dos dois aços, a fração volumétrica deste tipo de precipitado será menor do que a fração de $\mathrm{NbC}$.

Fiori et.al. [99], pertencentes ao grupo de pesquisa do LPE/LabH2S do PMT-EPUSP, e Haq et. al. [32], encontraram resultados parecidos com os aqui apresentados. Nesses dois trabalhos, ensaios de permeabilidade ao $\mathrm{H}$ foram conduzidos em aços microligados com diferentes teores de $\mathrm{Mn}$ e de $\mathrm{Nb}$ e foi observado que aços com menores teores de $\mathrm{Mn}$ e maiores teores de $\mathrm{Nb}$ apresentavam altos valores de $\mathrm{N}_{\mathrm{t}}$. Estes autores também associaram estes resultados à presença de $\mathrm{NbC}$, sendo que Haq et. al. [32] fizeram a caracterização destes precipitados.

Portanto, é essencial que sejam feitas análises de microscopia eletrônica de transmissão, principalmente no baixo $\mathrm{Mn}$, para caracterizar os $\mathrm{NbC}$.

Com o Thermo-Calc foi possível calcular a fração molar de NbC presente nos dois aços, em função da temperatura; os resultados são apresentados pela Figura 57. 

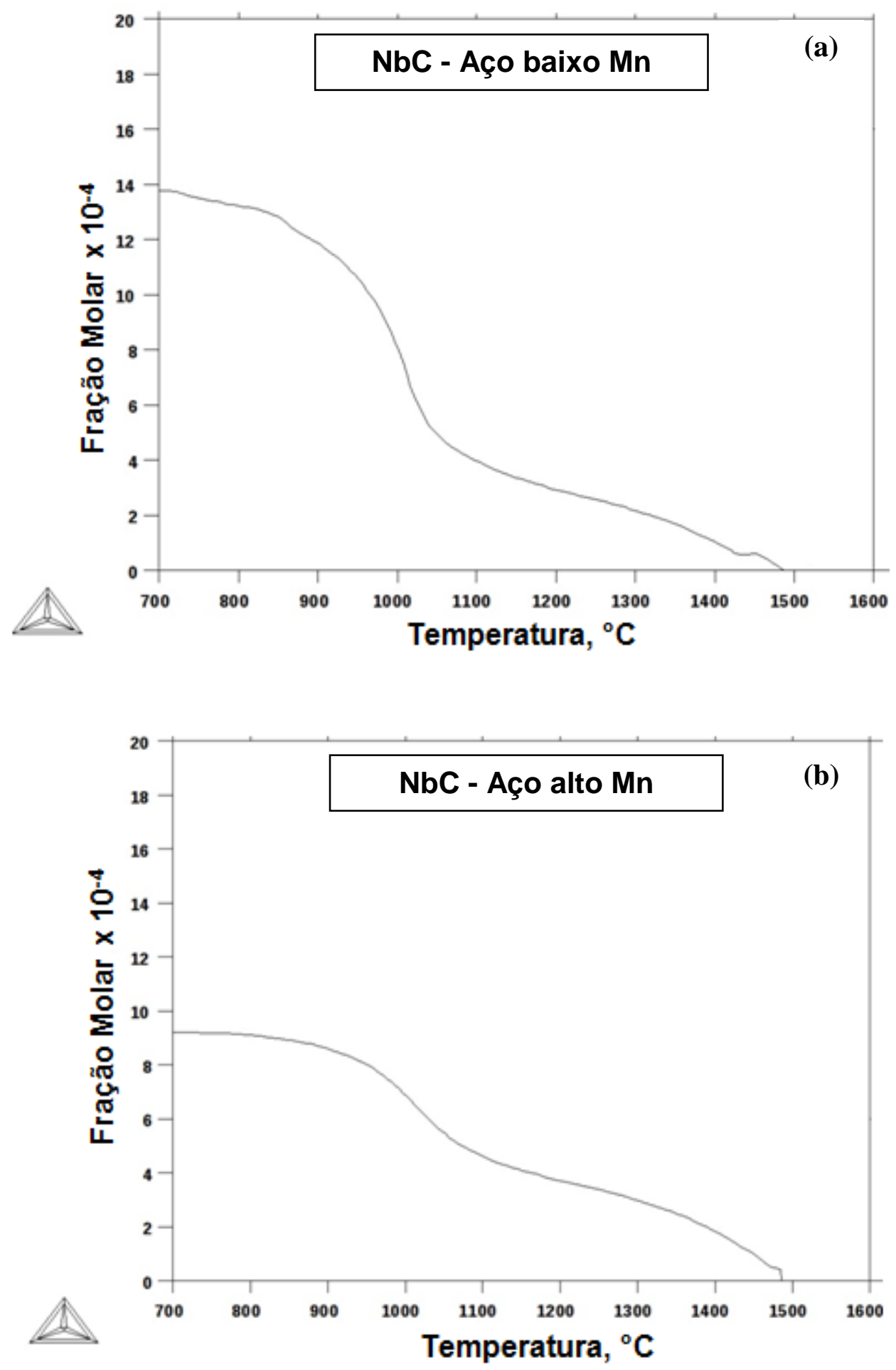

Figura 57. Frações molares de NbC em função da temperatura, obtidas por Thermo-Calc. (a) Aço baixo Mn, (b) aço alto $\mathrm{Mn}$.

Os resultados de Thermo-Calc mostram-se de acordo com o que era esperado: como o aço baixo $\mathrm{Mn}$ tem maior teor de $\mathrm{Nb}$ do que o alto $\mathrm{Mn}$, é coerente que a sua fração molar de $\mathrm{NbC}$ seja maior. 


\subsection{Análise do aço alto Mn: efeito do bandeamento}

Nesta seção são discutidos os resultados obtidos apenas para o aço alto Mn; porém, antes, é interessante comentar quais foram as motivações para que se escolhesse fazer os ensaios de permeabilidade nas seções longitudinal, transversal e do topo das chapas; o que motivou foram as seguintes perguntas: a quantidade de contornos de grão na superfície de entrada da amostra, associada ao formato dos grãos, pode influenciar a difusão do hidrogênio pelo material? Dependendo da seção da chapa (longitudinal, transversal ao sentido de laminação e do topo da chapa), o valor do coeficiente de difusão vai variar? Qual a influência de bandeamento na difusividade do $\mathrm{H}$ em aços? Para dar suporte teórico a estas perguntas, tomou-se como base o trabalho de Tau e Chan [64], discutido anteriromente, na seção 3.7.

Tau e Chan [64] trabalharam com amostras de uma chapa de aço AISI 4130 como recebidas, com microestrutura bandeada, e após tratamento térmico para eliminação do bandeamento, com microestrutura aleatória. As amostras como recebidas e tratadas termicamente foram retiradas das seções longitudinal, transversal e do topo da chapa, em relação ao sentido de laminação. Após ensaios de permeabilidade ao $\mathrm{H}$, os autores encontraram que o coeficiente de difusão efetiva do $\mathrm{H}$ no aço bandeado variou em função da seção ensaiada, enquanto que para o aço após o tratamento térmico, com microestrutura aleatória, o coeficiente de difusão efetiva do $\mathrm{H}$ apresentou valores similares para cada seção [64]. Neste espaço o foco será dado para a análise do aço alto Mn e, portanto, os resultados para o aço com microestrutura aleatória de Tau e Chan [64] não serão discutidos aqui.

$\mathrm{O}$ coeficiente de difusão efetiva do $\mathrm{H}\left(\mathrm{D}_{\text {eff }}\right)$ no aço bandeado de Tau e Chan variou da seguinte maneira: $D_{\text {eff }}$ longitudinal $>D_{\text {eff }}$ transversal $>D_{\text {eff }}$ topo; como já discutido na seção 3.7, esse comportamento foi atribuído à presença de bandas de ferrita e de perlita no material. As bandas de ferrita presentes na seção longitudinal, com menor quantidade de interface para aprisionar os átomos de $\mathrm{H}$, atuam como caminhos preferenciais para a sua difusão pelo aço, enquanto que, na seção do topo, a microestrutura é vista como uma matriz de ferrita com placas de perlita, com alta densidade de interface e, ao entrar no material pela seção do topo, os átomos de $\mathrm{H}$ têm sua mobilidade reduzida por estas placas. A microestrutura na seção transversal do aço bandeado de Tau e Chan [64] é composta por bandas de ferrita com algumas ilhas/placas de perlita em seu interior e é por esta razão que o coeficiente de difusão do $\mathrm{H}$ nesta seção tem valor intermediário às outras duas. A Figura 58, modificada do artigo de Tau e Chan [64], ilustra o exposto acima. 


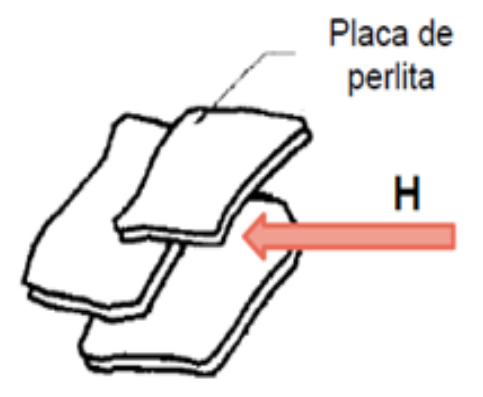

Longitudinal
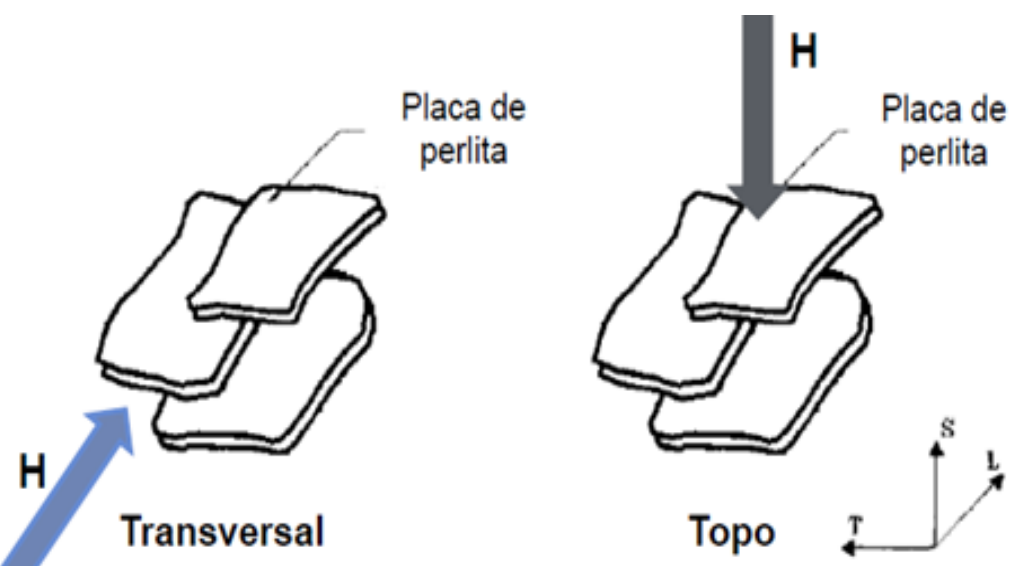

Figura 58. Esquematização para mostrar átomos de $H$ frente às placas de perlita, para cada seção de um aço bandeado. Modificado de [64].

Na esquematização da Figura 58, as setas coloridas indicam a direção e sentido dos átomos de $\mathrm{H}$ orientados por um campo elétrico, simulando o que acontece no ensaio de permeabilidade ao H (aplicação de corrente anódica orienta os átomos de H). Os espaços entre as placas de perlita consistem nas bandas de ferrita.

A Tabela 29 compara os valores de $\mathrm{D}_{\text {eff }} \mathrm{t}_{\text {lag }}$ do aço alto Mn (médias de cada seção) com os $\mathrm{D}_{\text {eff }}$ determinados por Tau e Chan [64] para seu aço com microestrutura bandeada. Os autores [64] não apresentaram desvio padrão de suas medidas de $\mathrm{D}_{\text {eff. }}$.

Tabela 29. Valores médios de coeficiente de difusão efetiva, calculados pelo método do time-lag, $\left(\mathrm{D}_{\text {eff }} \mathrm{t}_{\text {lag }}\right)$, para as seções longitudinal, transversal e topo do aço alto $\mathrm{Mn}$, junto de seus respectivos desvios padrão, e valores de $\mathrm{D}_{\text {eff }}$ do aço bandeado de Tau e Chan [64].

\begin{tabular}{|c|c|c|}
\hline & $\begin{array}{c}\text { Tau e Chan bandeada [64] } \\
\mathbf{D}_{\text {eff }}\left(\mathbf{c m}^{\mathbf{2} . \mathbf{s}^{-1}}\right)\end{array}$ & $\begin{array}{c}\text { X65 Alto Mn } \\
\mathbf{D}_{\text {eff }} \mathbf{t}_{\text {lag }}\end{array}$ \\
\hline Longitudinal & $7,7 \times 10^{-7}$ & $\left(\mathbf{c m}^{2} \cdot \mathbf{s}^{-1} \pm \mathbf{d e s v i o ~ p a d r a ̃ o}\right)$ \\
\hline Transversal & $4,2 \times 10^{-7}$ & $4,7 \times 10^{-6} \pm 6,0 \times 10^{-7}$ \\
\hline Topo & $2,2 \times 10^{-7}$ & $5,2 \times 10^{-6} \pm 4,0 \times 10^{-7}$ \\
\hline
\end{tabular}

A análise dos resultados da Tabela 29 permite que sejam feitas as seguintes observações: (1) os $\mathrm{D}_{\text {eff }}$ obtidos por Tau e Chan são uma ordem de grandeza mais baixos do

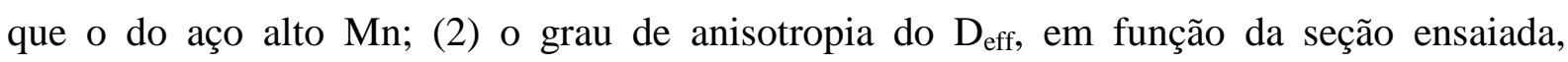
encontrado pelos autores é maior do que o do aço alto Mn. A ordem de grandeza a menos que os $D_{\text {eff }}$ de Tau e Chan [64] possuem, em comparação com os $D_{\text {eff }} t_{\text {lag }}$ dos aços estudados no 
presente trabalho (o aço baixo Mn também possui $D_{\text {eff }}$ na ordem de $10^{-6} \mathrm{~cm}^{2} \cdot \mathrm{s}^{-1}$ ), pode ser justificada pelo fato de se tratarem de tipos de aços diferentes. A composição química do aço AISI 4130 é diferente das dos aços microligados aqui estudados, contendo outros tipos e teores de elementos de liga, além de poder ter outras características microestruturais não discutidas pelos autores, como as inclusões, que podem ser responsáveis pelo coeficiente de difusão mais baixo. Além disso, as condições do ensaio de permeabilidade ao H usadas por [64] são diferentes: eletrólito do lado catódico da célula composto por solução de $0,1 \mathrm{~N}$ de $\mathrm{NaOH}$ e $20 \mathrm{mg} / \mathrm{L}$ de $\mathrm{As}_{2} \mathrm{O}_{3}$; eletrólito do lado anódico composto por solução de $0,1 \mathrm{~N}$ de $\mathrm{NaOH}$; aplicação de corrente catódica de $2 \mathrm{~mA} \cdot \mathrm{cm}^{-2}$ e de potencial anódico de $+100 \mathrm{mV} / \mathrm{ECS}$. Segundo Haq et. al. [32], fatores como tipo de elétrolitos usados e concentração de veneno catódico, entre outros parâmetros experimentais, podem influenciar os resultados obtidos pelo método eletroquímico [32].

A proximidade entre os valores de $\mathrm{D}_{\text {eff }}$ das amostras longitudinal e transversal do aço alto $\mathrm{Mn}$, pode ser explicada pelas características microestruturais das mesmas. Para isso é preciso reproduzir abaixo parte da Figura 34 e parte da Figura 35, que serão chamadas de Figuras 59 e 60.
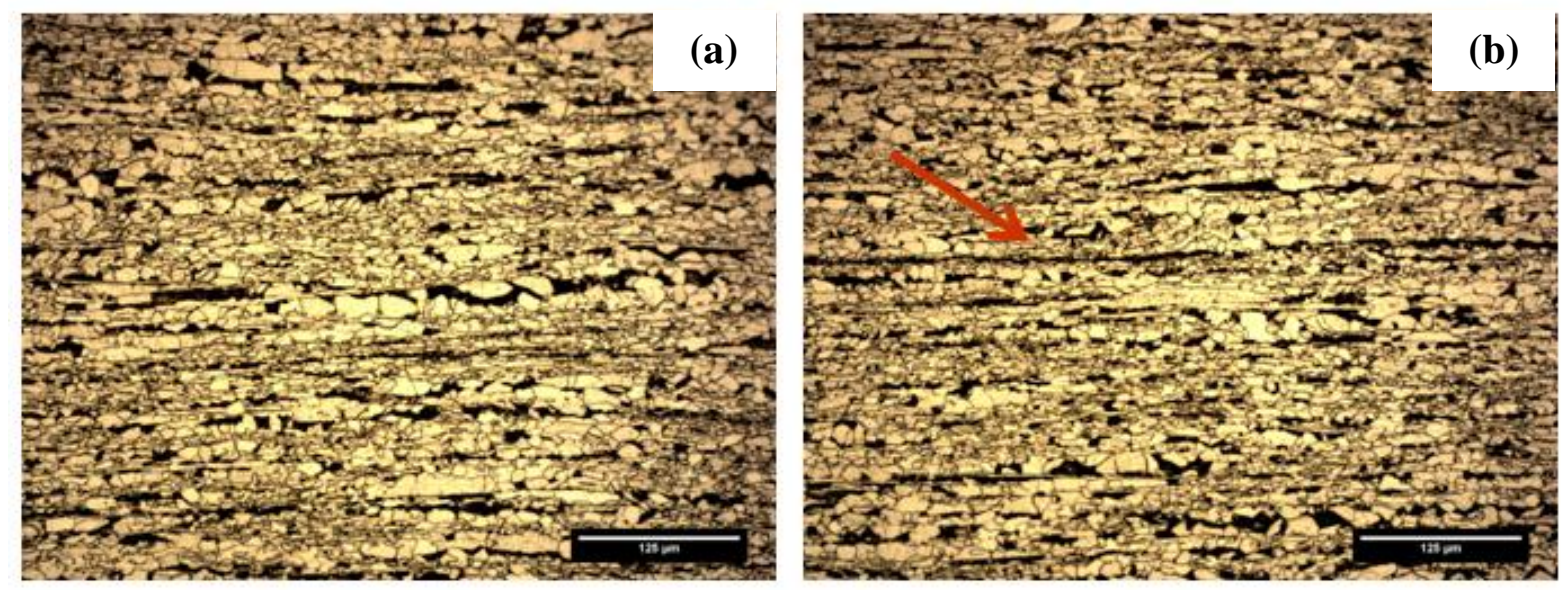

Figura 59. Micrografias ópticas das diferentes seções do aço alto Mn. (a) região periférica e (b) região central da superfície longitudinal; (c) região periférica e (d) região central da superfície transversal. Ataque: Nital $2 \%$. Aumento: $200 \mathrm{x}$. 



Figura 59. (Continuação) Micrografias ópticas das diferentes seções do aço alto Mn. (a) região periférica e (b) região central da superfície longitudinal; (c) região periférica e (d) região central da superfície transversal. Ataque: Nital 2\%. Aumento: $200 \mathrm{x}$.
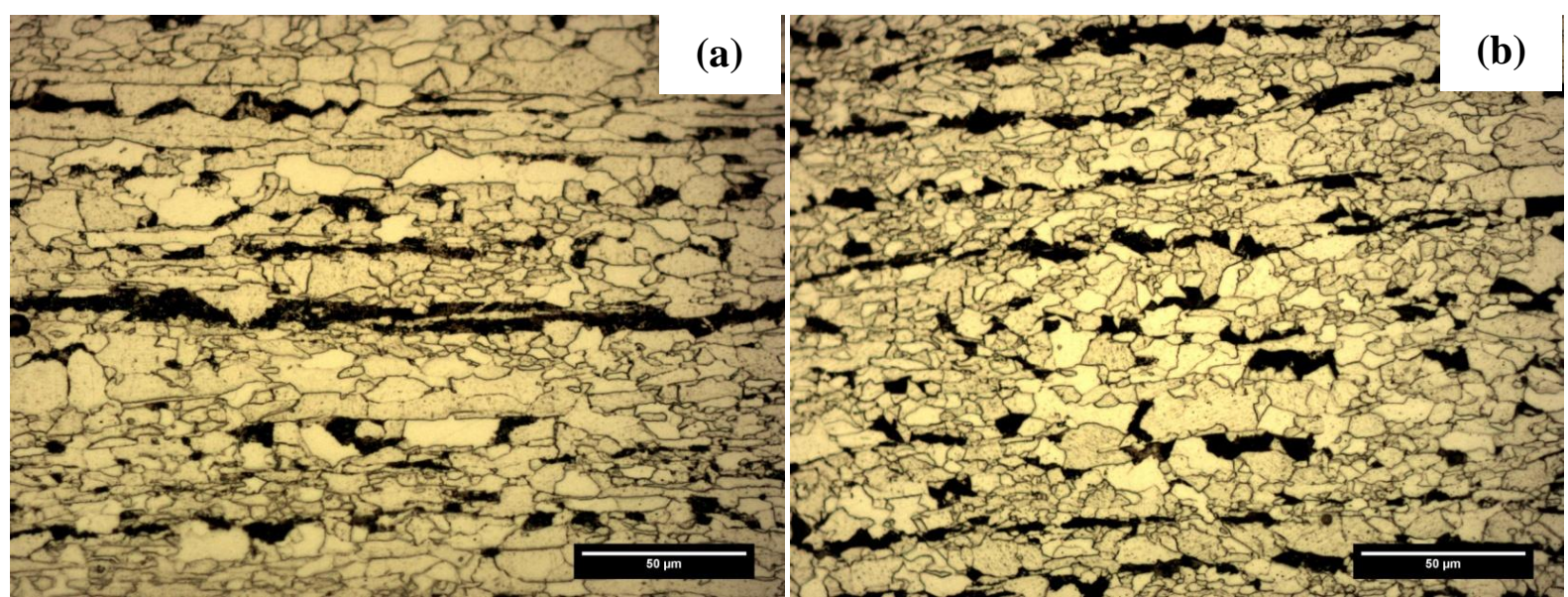

Figura 60. Micrografias ópticas das diferentes seções do aço alto Mn, em suas regiões centrais. (a) Longitudinal e (b) transversal. Ataque: Nital 2\%. Aumento: 500 x.

Como se pode notar pelas Figuras 59 e 60, especialmente pelas micrografias das regiões centrais das amostras (durante o ensaio de permeabilidade ao $\mathrm{H}$, as regiões centrais das amostras são expostas aos eletrólitos, como se pode ver pela Figura 17 da seção 3.6 e pela Figura 24 da seção 4.2.5) as colônias de perlita e os grãos de ferrita na seção transversal se mostram mais equiaxiais do que na seção longitudinal. Além disso, as bandas de perlita apresentam descontinuidades mais pronunciadas na seção transversal do que na outra, contudo, o espaçamento médio entre as bandas de ferrita e perlita é parecido, qualitativamente, para as duas amostras. Em outras palavras, fora a diferença de formato dos grãos entre as duas amostras e algumas descontinuidades nas bandas de perlita da amostra transversal, não foram observadas outras divergências microestruturais significativas entre as seções, o que justifica os valores de $\mathrm{D}_{\text {eff }}$ próximos. Já o menor valor de $\mathrm{D}_{\text {eff }}$ encontrado para a 
seção do topo pode ser explicado como proposto por Tau e Chan [64] e de acordo com a Figura 58.

A Tabela 23 mostra que os $D_{\text {eff }} t_{\text {lag }}$ das amostras topo do aço alto Mn não tendem para um valor, ou faixa de valores, aproximados. Este comportamento pode ser oriundo da heterogeneidade da microestrutura na seção topo do aço alto Mn. As Figuras 34(e), 34(f), 35(c) e 35(d) mostram que, nesta seção, as placas de perlita aparecem mais concentradas em determinadas regiões do que em outras. $\mathrm{O}$ alto desvio padrão associado à fração volumétrica média de perlita nessa seção (Tabela 16), também descreve essa heterogeneidade. Logo, os valores de $D_{\text {eff }} t_{\text {lag }}$ das amostras topo do aço alto $\mathrm{Mn}$, divergentes entre si, podem ser justificados pela exposição de regiões com maiores ou menores frações volumétricas de perlita, durante o ensaio de permeabilidade ao H. Quando a área exposta ao eletrólito tiver maior fração volumétrica de perlita o $\mathrm{D}_{\text {eff }} \mathrm{t}_{\text {lag }}$ será mais baixo, quando esta fração for menor, o $D_{\text {eff }} t_{\text {lag }}$ será mais alto.

Para verificar a validade da hipótese do bandeamento descrita acima, foi proposto o cálculo de um novo coeficiente de difusão, $\mathrm{D}_{\mathrm{ss}}$, difusão no estado estácionário [100]. Para a obtenção deste coeficiente, utilizou-se a $1^{\text {a }}$ Lei de Fick, que pode ser aplicada quando é atingido o estado estacionário, o valor de $\mathrm{J}_{\infty}$ (fluxo de $\mathrm{H}$ no estado estacionário) e a espessura da amostra (e). A concentração de $\mathrm{H}$, nesse caso, foi mantida como uma constante $\mathrm{C}$ e multiplicada pelo coeficiente de difusão $\mathrm{D}$, formando o $\mathrm{D}_{\mathrm{ss}}$. Abaixo é apresentada a Equação 20, usada para o cálculo de $\mathrm{D}_{\mathrm{ss}}$. Os resultados são mostrados graficamente pela Figura 61 .

$$
D_{S S}=J_{\infty} \cdot e
$$






Figura 61. Valores do novo coeficiente de difusão no estado estacionário, $D_{s s}$, calculados para as seções longitudinal, transversal e topo do aço alto $\mathrm{Mn}$.

Os valores de $\mathrm{D}_{\mathrm{ss}}$ variam para cada seção do aço alto Mn de modo similar aos $\mathrm{D}_{\text {eff }}$, o que ajuda na validação da hipótese do efeito do bandeamento. Isso significa que além de aprisionar os átomos de $\mathrm{H}$ reversivelmente, o que por si só diminui o coeficiente de difusão, as placas de perlita se comportam como obstáculos físicos, mais difíceis de transpor, à migração dos átomos de $\mathrm{H}$. O $\mathrm{D}_{\text {eff }} \mathrm{t}_{\mathrm{lag}}$, então, tem seu valor dependente de dois processos distintos: o aprisionamento dos átomos de $\mathrm{H}$ (ligação dos átomos de $\mathrm{H}$ com os traps) e a redução da mobilidade dos átomos de $\mathrm{H}$ por causa de obstáculos físicos (placas de perlita).

\subsection{Análise do aço baixo Mn: efeito da quantidade de contornos de grão de ferrita e da textura}

Tau e Chan [64] encontraram que, para o aço com microestrutura aleatória, ou seja, sem bandeamento, composta por ferrita e ilhas de perlita e homogênea nas três seções, o $D_{\text {eff }}$ era aproximadamente o mesmo para as amostras longitudinais, transversais e topo. Neste caso, não há um caminho preferencial para o $\mathrm{H}$ se difundir e nem obstáculos específicos ao seu movimento, como as placas de perlita. A Figura 62 ilustra a situação do $H$ frente à microestrutura aleatória. 


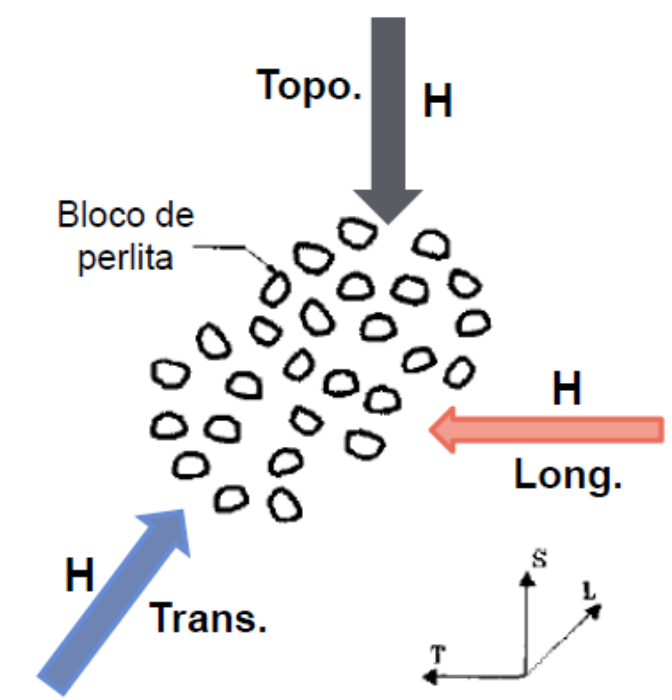

Figura 62. Esquematização mostrando os átomos de H frente à microestrutura aleatória. Modificado de [64].

Como a microestrutura aleatória do aço homogeneizado de Tau e Chan [64] é similar à microestrutura do aço baixo Mn, que é homogêna para as três seções analisadas, esperava-se que o $D_{\text {eff }} t_{\text {lag }}$ também tivesse valores similares para as amostras longitudinal, transversal e topo. Porém, como já mostrado pela Tabela 22, isso não acontece. A Tabela 30 compara os resultados de Tau e Chan para o aço com microestrutura aleatória com as médias dos $\mathrm{D}_{\text {eff }} \mathrm{t}_{\mathrm{lag}}$ calculadas para o aço baixo Mn.

Tabela 30. Valores médios de coeficiente de difusão efetiva, calculados pelo método do time-lag, $\left(\mathrm{D}_{\text {eff }} \mathrm{t}_{\mathrm{lag}}\right)$, para as seções longitudinal, transversal e topo do aço baixo Mn, junto de seus respectivos desvios padrão, e valores de $\mathrm{D}_{\text {eff }}$ do aço de microestrutura aleatória de Tau e Chan [64].

\begin{tabular}{|c|c|c|}
\hline & $\begin{array}{c}\text { Tau e Chan aleatória [64] } \\
\mathbf{D}_{\text {eff }}\left(\mathbf{c m}^{2} \cdot \mathbf{s}^{-\mathbf{1}}\right)\end{array}$ & $\begin{array}{c}\text { X65 baixo Mn } \\
\mathbf{D}_{\text {eff }} \mathbf{t}_{\text {lag }}\end{array}$ \\
\hline Longitudinal & $5,16 \times 10^{-7}$ & $5,9 \times 10^{-6} \pm 9,5 \times 10^{-7}$ \\
\hline Transversal & $5,38 \times 10^{-7}$ & $5,6 \times 10^{-6} \pm 1,1 \times 10^{-6}$ \\
\hline Topo & $5,51 \times 10^{-7}$ & $3,1 \times 10^{-6} \pm 1,3 \times 10^{-6}$ \\
\hline
\end{tabular}

$\mathrm{Na}$ Tabela 30, os altos desvios padrão associados aos $\mathrm{D}_{\text {eff }}$ do aço baixo Mn provêm do baixo número de repetições. Para a amostra do topo, especificamente, o desvio mais alto descreve a dispersão observada nos valores de $\mathrm{D}_{\text {eff }}$ desta seção. A melhor forma de apresentar estes resultados é através de tabelas e gráficos contendo todas as medidas realizadas, como já foi feito na Tabela 22 e Figura 53; aqui, só foram mostrados esses valores médios para 
comparação com o trabalho de Tau e Chan [64], que aparentemente não fizeram tratamento estatístico de seus resultados.

Os valores de $\mathrm{D}_{\text {eff }} \mathrm{t}_{\text {lag }}$ das amostras longitudinais e transversais do aço baixo $\mathrm{Mn}$ foram próximos, podendo ser considerados iguais, e os coeficientes de difusão efetiva das amostras do topo da chapa foram inferiores e variaram entre si. Curiosamente, o aço baixo $\mathrm{Mn}$ exibiu o mesmo comportamento que o aço alto $\mathrm{Mn}$, apesar de todas as suas diferenças microestruturais.

O aço baixo Mn foi estudado e ensaiado em seu estado como recebido, ou seja, laminado, apresentando grau de textura e grãos levemente deformados nas seções longitudinal e transversal; já o aço com microestrutura aleatória de Tau e Chan passou por tratamento térmico de homogeneização antes dos ensaios de permealibidade, removendo deformações dos grãos decorrentes da laminação e transformando a textura do material. Por estas razões, a hipótese proposta por Tau e Chan [64] para explicar a isotropia do $\mathrm{D}_{\text {eff }}$ de seu aço aleatório não pode ser aplicada ao aço baixo Mn.

Os resultados para o aço baixo Mn podem ser entendidos a partir de uma abordagem um pouco mais complexa, que envolve os contornos de grão de ferrita e a textura cristalográfica originada do processamento do aço.

Antes de se entrar nesta nova abordagem mais complexa, é preciso comentar sobre os outros traps presentes no aço baixo $\mathrm{Mn}$. A possível presença dos $\mathrm{NbC}$ no aço baixo Mn não foi considerada para explicar a anisotropia observada nos valores de $D_{\text {eff. Supõe-se que os }}$ $\mathrm{NbC}$ tenham formatos aproximadamente globulares e sejam finos, nanométricos, distribuídos de maneira homogênea pelo volume do material. Assim, dadas as suas supostas características, admite-se que a sua interação com os átomos de H não irá depender da seção do material e, portanto, não seria aplicável para explicar a anisotropia do $\mathrm{D}_{\text {eff }} \mathrm{t}_{\text {lag }}$. As inclusões e as ilhas de perlita, que por sua vez foram caracterizadas, também não são usadas para explicar a diferença nos valores de $\mathrm{D}_{\text {eff }} \mathrm{t}_{\mathrm{lag}}$, já que a sua distribuição pelo volume do material é homogênea. As ilhas de perlita, ainda, aparecem em baixa fração volumétrica no aço, fazendo com que a sua contribuição seja considerada como pouco significativa para o $D_{\text {eff }} t_{\text {lag }}$.

Em função do processo TMCR, no qual um alto grau de refinamento dos grãos ferríticos é obtido a partir de grãos deformados e em forma de panqueca de austenita, a microestrutura do aço baixo Mn apresenta subgrãos, ou subestruturas herdadas da deformação da austenita. Estas subestruturas foram evidenciadas pelos mapas de contornos de grão obtidos por EBSD e apresentados na Figura 49, e correspondem aos contornos de baixo e 
médio ângulo da ferrita. A técnica de EBSD forneceu, também, o comprimento de contornos de grão para cada amostra do aço baixo Mn. A amostra longitudinal apresenta maior comprimento de contornos de grãos, seguida da transversal e da topo, como vê-se na Tabela 20. Esse comprimento de contornos grãos mencionado corresponde à soma dos comprimentos dos três tipos de contornos de grão mensurados por EBSD: alto, médio e baixo ângulo.

Outra característica do aço baixo Mn é a textura cristalográfica, representada simplificadamente pelos mapas de figura de polo inverso da Figura 50. Por eles é possível ver que a amostra longitudinal apresenta maior parte dos grãos nos planos $\{111\}$ e variando entre os planos $\{111\}$ e $\{101\}$; na amostra transversal observa-se que os principais planos são os $\{101\}$ seguidos dos $\{001\}$ e na amostra topo a textura é mais aleatória.

Quando se tenta correlacionar os resultados de textura com os valores de $D_{\text {eff }} t_{\text {lag }}$ obtidos, não se encontra uma relação clara. As amostras longitudinais e transversais apresentaram $D_{\text {eff }} t_{\text {lag }}$ iguais, porém texturas diferentes. De acordo com Jiang e Carter [75], as superfícies preferenciais para entrada e difusão de $H$ na ferrita pura são a $\{100\}$ e a $\{110\}$; ao olhar para os valores de $D_{\text {eff }} t_{\text {lag }}$ do aço baixo Mn e suas texturas, não se vê concordância alguma com estes resultados, então, inicialmente, pensou-se que a textura do aço baixo Mn não tivesse papel signficativo para a difusão do $\mathrm{H}$, por se apresentar pouco definida. Logo, partiu-se para outra análise, que envolve a quantidade de contornos de grão de alto, médio e baixo ângulo.

As amostras longitudinais e transversais apresentaram os maiores comprimentos de contornos de grão, de 5,29 cm e 5,09 cm, respectivamente, e seus valores de $D_{\text {eff }} t_{\text {lag }}$ foram os mais altos e também muito similares. A amostra topo contém o menor comprimento de contornos, de 4,02 cm, e seus valores de $D_{\text {eff }} t_{\text {lag }}$ foram, também, os mais baixos. A partir disso, é possível estabelecer uma relação entre esses dois resultados.

A solubilidade do $\mathrm{H}$ no ferro é baixa, como pode ser visto pela Figura 1, e, de acordo com Jiang e Carter [75], os átomos de H preferem ficar na superfície da ferrita pura do que em subsuperfícies ou no bulk - a barreira de energia para difusão de subsuperfícies para a superfície é muito baixa, de aproximadamente $0,03 \mathrm{eV}$ [75]. Como já mencionado em seções anteriores, a presença de defeitos microestruturais altera este comportamento do $\mathrm{H}$ : os defeitos, de modo geral, consistem em sítios energeticamente mais favoráveis para o H ocupar do que os sítios normais da rede cristalina (Figura 10).

Por causa de seus baixos valores de $\mathrm{E}_{\mathrm{S}}$ (energia de migração para o trap) e de $\mathrm{E}_{\mathrm{b}}$, os contornos de grão são classificados como traps reversíveis. Em comparação com precipitados 
e inclusões, os contornos de grão conseguem aprisionar o $\mathrm{H}$ mais facilmente (baixa $\mathrm{E}_{\mathrm{s}}$ ), porém, não conseguem manter estes átomos presos a eles por tempos muito longos, ou ilimitados (baixa $E_{b}$ ). Ao se pensar na estabilidade energética do $\mathrm{H}$ em um sítio, pode-se classificar os traps do aço baixo Mn em ordem decrescente de energia potencial da seguinte maneira: $S_{\mathrm{cg}} \cong S_{\text {ferr/cem }}>S_{\text {precip }}>S_{\text {inclusão, }}$ onde $S_{\mathrm{cg}}=$ energia potencial do contorno de grão de ferrita, $S_{\text {ferr/cem }}=$ energia potencial da interface ferrita/cementita, $S_{\text {precip }}=$ energia potencial do precipitado, possivelmente do tipo $\mathrm{NbC}$, e $\mathrm{S}_{\text {inclusão }}=$ energia potencial de inclusão composta por $\mathrm{Al}, \mathrm{O}$ e Ca. Em termos de energia de migração para o trap de $\mathrm{H}$, os traps são classificados de modo contrário: $\mathrm{E}_{\mathrm{s}, \mathrm{cg}} \cong \mathrm{E}_{\mathrm{s} \text {, ferr/cem }}<\mathrm{E}_{\mathrm{s} \text {, precip }}<\mathrm{E}_{\mathrm{s} \text {, inclusão. }}$.

Os traps reversíveis são considerados como os mais perigosos para as propriedades mecânicas dos aços, porque acabam atuando como reservatórios de $\mathrm{H}$ móvel $[47,56]$. O H aprisionado pelos sítios reversíveis será drenado, em algum momento, por sítios de energia potencial mais baixa, muitas vezes localizados em regiões concentradoras de tensão, como interfaces de ripas de martensita, e, assim, fragilizarão o material [56]. No caso do aço baixo Mn, produzido com o uso de técnicas excelentes e, por isso, sem regiões concentradoras de tensão, o H aprisionado reversivelmente pelos contornos de grão é drenado pelos sítios de energia potencial mais baixa, que são os nanoprecipitados de $\mathrm{NbC}$ e as finas inclusões globulares de $\mathrm{Al}, \mathrm{O}$ e $\mathrm{Ca}$.

Com base em todas essas informações, a difusão efetiva do $\mathrm{H}$ pode ser descrita em etapas, em função do tempo de ensaio de permeabilidade:

1) Em um tempo de ensaio $\mathrm{t}_{0}=0$, os átomos de $\mathrm{H}$ do meio sour em contato com a superfície do aço baixo Mn se deparam com todos os tipos de traps presentes. Os átomos de $\mathrm{H}$ vão entrar no material, ocupar sítios intersticiais, traps reversíveis e irreversíveis, porém, por causa do seu baixo valor de $\mathrm{E}_{\mathrm{s}}$, os átomos de $\mathrm{H}$ migrarão mais facilmente para os contornos de grão.

2) Por causa da baixa energia de ligação com os átomos de $\mathrm{H}$, os contornos de grão de ferrita irão atuar como fontes de H móvel, a partir das quais os traps irreversíveis, de mais baixas energias potenciais, irão drenar átomos de $\mathrm{H}$ e aprisioná-los, até atingirem a sua saturação.

3) Quanto $t=t_{b}$ (Figura 18), os primeiros átomos de $\mathrm{H}$ conseguem atravessar a espessura da amostra e ser detectados em sua face de saída. A região transiente da curva de permeabilidade começa a ser formada. 
4) Para $\mathrm{t}>\left(\mathrm{t}_{0}\right.$ e $\left.\mathrm{t}_{\mathrm{b}}\right)$, traps irreversíveis localizados em regiões mais próximas do bulk vão sendo saturados e se tornando inativos, ou seja, deixam de interagir com novos átomos de $\mathrm{H}$ que entram no material. Isso faz com que a fração de $\mathrm{H}$ que atravessa a amostra e é detectada na face de saída aumente (aumento da densidade de corrente de permeabilidade). Os contornos de grão da superfície do aço, voltada para a célula de carregamento, continuam facilitando a entrada de átomos de H no material (atuam como portas de entrada de H). Já, nas subsuperfícies e no bulk, os contornos de grão mantêm o seu papel de reservatório de H móvel (para saturação de traps irreversíveis) e também passam a atuar como caminhos preferenciais para a difusão do $\mathrm{H}$.

5) O processo ocorre até a saturação de todos os traps irreversíveis, de modo que o H se difunde por todo o volume.

Como os contornos de grão atuam como fontes de $\mathrm{H}$ móvel no interior da amostra, quanto maior a sua quantidade, mais fácil se torna a difusão do $\mathrm{H}$ pelo interior do aço. A relação observada entre $D_{\text {eff }} t_{\text {lag }}$ e comprimento de contornos de grão, mencionada no começo da discussão, pode ser considerada válida.

Assim como para o aço alto $\mathrm{Mn}$, fez-se o cálculo do $\mathrm{D}_{\mathrm{ss}}$, o coeficiente de difusão que considera todos os traps saturados e, portanto, que deve ser influenciado apenas pelos obstáculos físicos à movimentação dos átomos, como as placas de perlita do primeiro aço. A Figura 63 a seguir apresenta os valores de $\mathrm{D}_{\mathrm{ss}}$ calculados para cada amostra do aço baixo $\mathrm{Mn}$. 


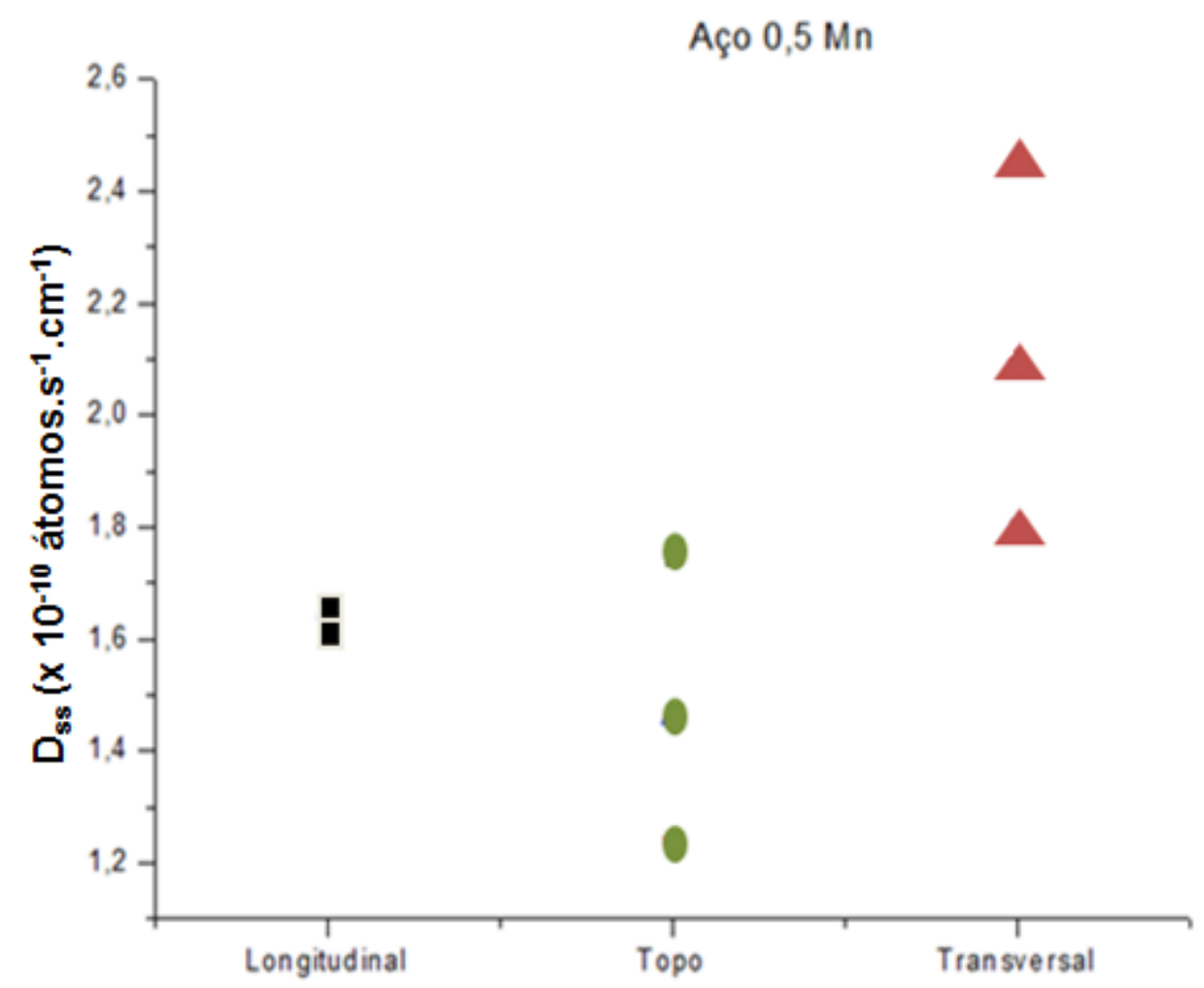

Figura 63. Valores do coeficiente de difusão do $\mathrm{H}$ no estado estacioonário, $\mathrm{D}_{\mathrm{ss}}$, calculados para as três seções do aço baixo Mn.

No estado estacionário, a quantidade de $\mathrm{H}$ que entra no material irá se difundir, sem ser aprisionada por traps, e será a mesma a sair (região iii da Figura 18). O aço baixo Mn não apresenta em seu volume microconstituintes que interajam com $\mathrm{H}$ de maneiras diferentes dependendo da seção ensaiada, como acontece com o aço alto Mn e suas placas de perlita. Logo, não seria surpreendente se, após a saturação dos sítios de aprisionamento, $\mathrm{o}_{\mathrm{ss}}$ fosse o mesmo para as três seções. Contudo, observa-se que o $\mathrm{D}_{\mathrm{ss}}$ das amostras longitudinais e do topo são mais baixos do que os calculados para as amostras transversais. Ainda, os $D_{\mathrm{ss}}$ calculados nas seções transversais e do topo variaram entre si. É provável que o fator responsável por este comportamento seja a textura cristalográfica.

Como a textura neste aço é fraca, característica que é comum a aços laminados a quente $[26,96]$ o seu efeito no $D_{\text {eff }} t_{\text {lag }}$ acaba sendo encoberto pela influência da saturação dos traps, auxiliada por contornos de grão. A Figura 64 reapresenta os mapas de IPF obtidos para as amostras do aço baixo $\mathrm{Mn}$, para facilitar a comparação com os valores de $\mathrm{D}_{\mathrm{ss}}$. 

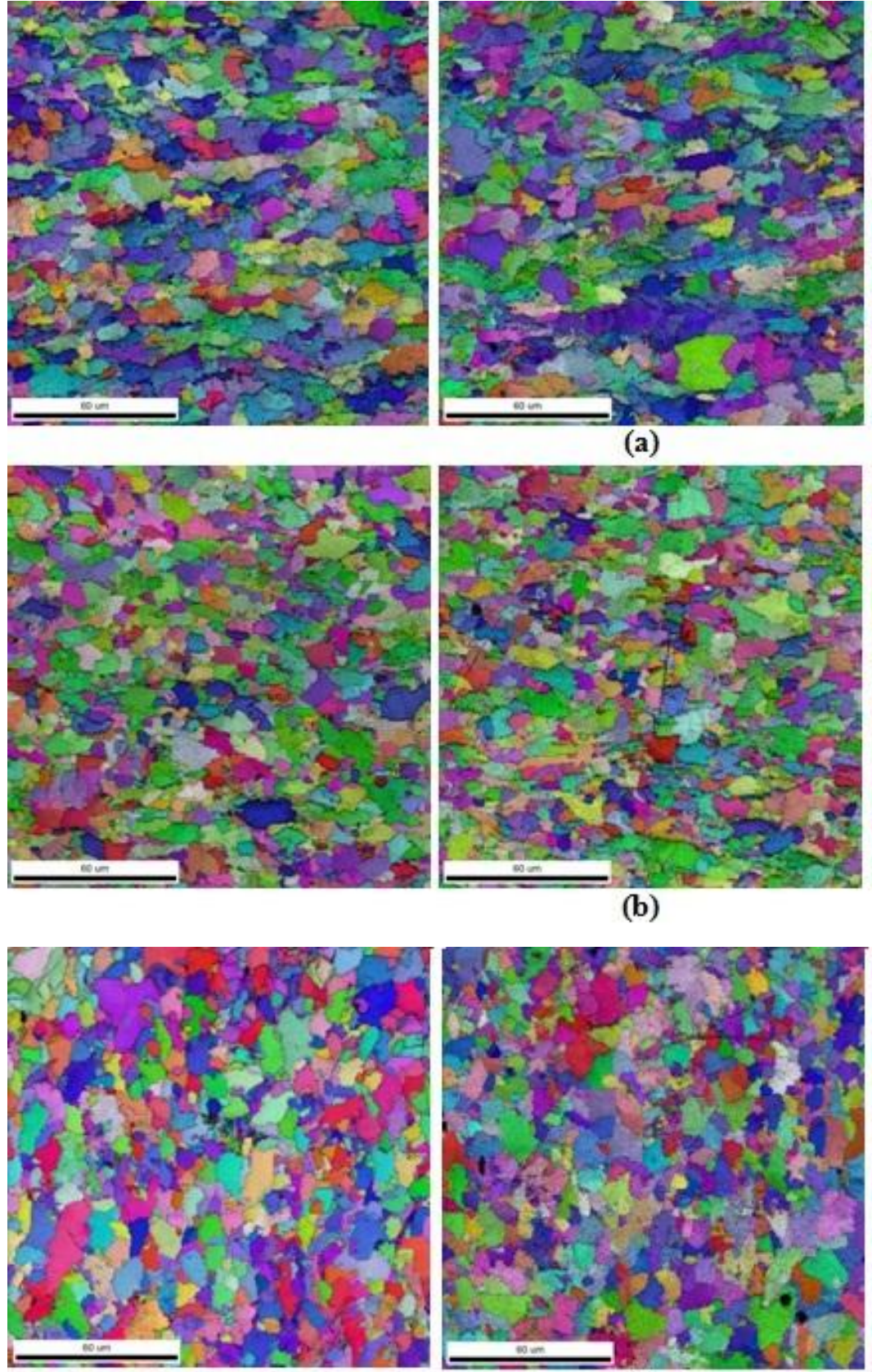

(c)

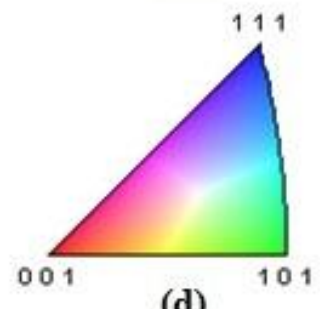

(d)

(b)

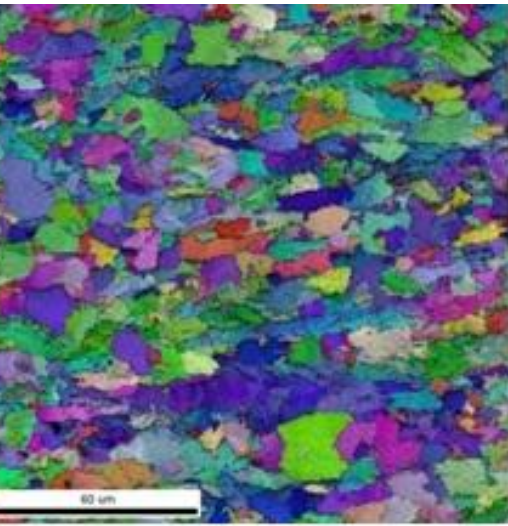

(a)

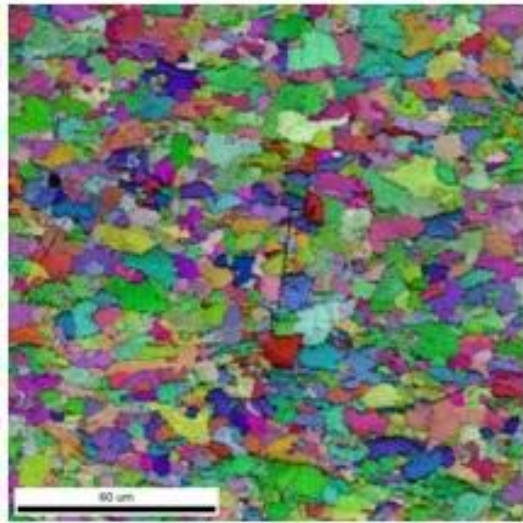

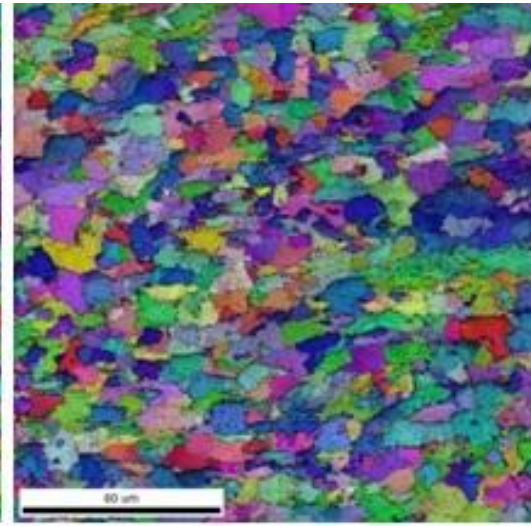
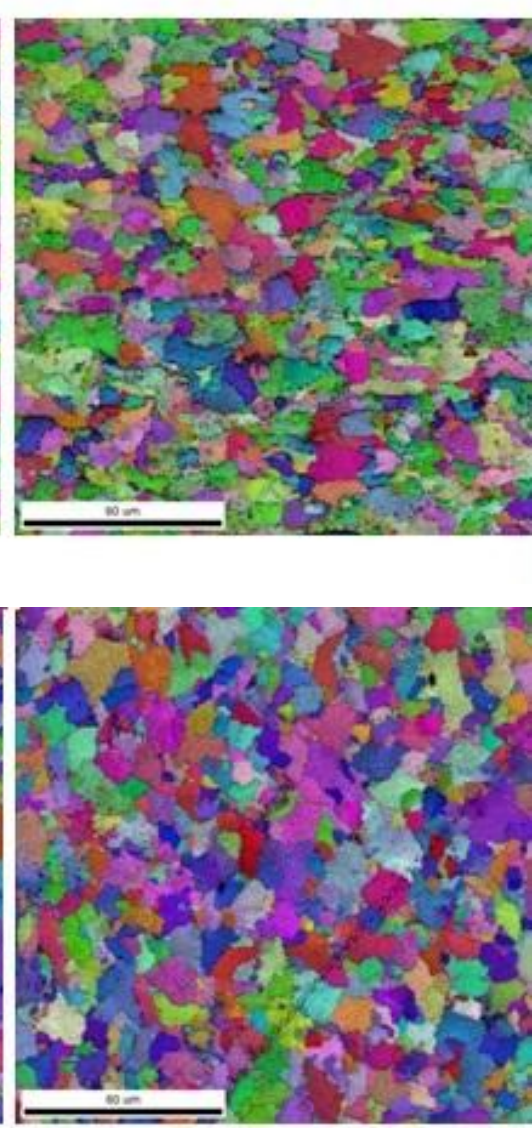

$w=$

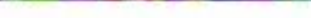

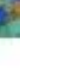


Os mapas reapresentados pela Figura 64 foram obtidos a partir de uma amostra de cada condição, cada amostra dessas tinha em torno de $1 \mathrm{~cm}^{2}$ de área. As regiões mostradas pelos mapas correspondem a áreas muito inferiores a $1 \mathrm{~cm}^{2}$ de material, já que foram obtidas com aumento de 1500 x. Como já explicado, por conta da transformação de austenita em ferrita que ocorre durante o resfriamento de aços laminados à quente, a textura resultante na seção paralela ao sentido de laminação é fraca; a textura também pode variar ao longo da espessura da chapa. Logo, os mapas da Figura 64 são de microtextura, ou de textura localizada, e indicam apenas uma tendência da orientação cristalográfica preferencial dos grãos na chapa de aço. Para obter informações sobre a macrotextura do material seria necessário fazer análises por Difração de Raios X, através das quais áreas maiores de amostras podem ser estudadas.

Ao relacionar os resultados de textura com os de $\mathrm{D}_{\mathrm{ss}}$, pode-se propor que a abundancia de planos $\{111\}$ em uma das direções retarda a difusão do H nesta direção, uma vez que estes aparecem em maior quantidade na amostra longitudinal, cujo $\mathrm{D}_{\mathrm{ss}}$ foi baixo. A amostra topo apresenta textura mais aleatória do que as demais, e contém parte dos grãos em planos que variam do $\{111\}$ ao $\{001\}$ (do azul ao vermelho, passando pelo roxo). Cao et. al. [78] mostraram a influência de textura nos parâmetros de permeabilidade ao $\mathrm{H}$ em membranas de níquel, o qual tem estrutura CFC; embora o aço baixo Mn seja predominantemente ferritico, CCC, apresenta resultados análogos. Os autores encontraram que a amostra com textura aleatória apresentou o coeficiente de difusão mais baixo de todos, acompanhada de maior valor de $\mathrm{C}_{0}$ [78]. Este resultado de Cao et. al. concorda com o que foi observado para as amostras topo, tanto pelos valores de $\mathrm{D}_{\mathrm{ss}}$, como de $\mathrm{C}_{0}, \mathrm{~N}_{\mathrm{t}}$ e o valor de fluxo de $\mathrm{H}$ liberado pelo aço, obtido por dessorção térmica após carregamento de $17 \mathrm{~h}$. Os autores também reportam que, em suas membranas de Ni com texturas $\{111\}$, o coeficiente de difusão foi mais alto, seguida da textura $\{110\}$ [78]. Os planos de maior densidade atômica na estrutura CFC são os $\{111\}$; na estrutura CCC do aço baixo Mn, estes planos são os $\{101\}$. Logo, os resultados das amostras transversais do aço baixo Mn também concordam, de certa forma, com os de Cao et. al. [78]: a textura de planos de maior densidade atômica proporciona o maior valor de coeficiente de difusão. Os planos de maior densidade atômica são os mais espaçados entre si e com maiores interstícios (estruturas mais abertas), de modo que a densidade volumétrica do material, no caso a ferrita, é mantida constante [79]. Isso pode justificar os valores de coeficiente de difusão do $\mathrm{H}$ mais elevados. Ainda, a correlação entre $D_{\text {ss }}$ e textura para a seção transversal do aço baixo Mn também se mostra de acordo com o que 
foi encontrado por Jiang e Carter [75] e já mencionado anteriormente no texto: através de cálculos de DFT os autores mostraram que as superfícies preferenciais para difusão do $\mathrm{H}$ em monocristais de ferrita pura são as $\{100\}$ e $\{110\}$ [75].

Uma melhor análise dos resultados de textura é necessária para se chegar a conclusões mais assertivas sobre a difusão do $\mathrm{H}$ no aço baixo Mn. A interpretação da textura, identificação de suas componentes, ainda não foi completada, faltando, também, quantificar as componentes de textura. $\mathrm{O}$ que foi apresentado aqui é apenas uma análise inicial da influência da textura na difusão do $\mathrm{H}$.

\subsection{Considerações finais}

Para finalizar a discussão, é importante explicar que o ensaio de permeabilidade ao $\mathrm{H}$ não é capaz de determinar, sozinho, a suscetibilidade de um material à fragilização por H. Ele fornece dados, como o $\mathrm{D}_{\text {eff }}, \mathrm{C}_{0}$ e $\mathrm{N}_{\mathrm{t}}$, que ajudam no entendimento do comportamento do $\mathrm{H}$ no interior do material e somente em conjunto com outras técnicas, como os ensaios de HIC, é possível determinar com mais certeza se o material é resistente ou não à fragilização por $\mathrm{H}$. $\mathrm{O}$ ensaio de permeabilidade ao $\mathrm{H}$ é muito importante para o entendimento dos mecanismos que levam à fragilização e à falha por $\mathrm{H}$. Um valor de $\mathrm{D}_{\text {eff }}$ baixo, por exemplo, não é garantia de que o material tenha baixa resistência aos danos pelo H. A distribuição dos traps, como carbonitretos e inclusões arredondadas e pequenas, tem fundamental importância para esta propriedade. Traps distribuídos homogeneamente pelo volume do aço podem ser, na verdade, os responsáveis pelo aumento da resistência à fragilização por $\mathrm{H}$, e um aço com alta densidade desses traps irá apresentar baixo coeficiente de difusão.

O papel da textura na resistência à fragilização por H é ainda mais complexo: a relação entre textura, fragilização por H e difusão do H não é direta. Há outras abordagens envolvidas proporcionadas pela textura, como caminhos preferenciais para propagação de trincas, e outras características além da textura que podem levar ao aumento ou diminuição da suscetibilidade aos danos por $\mathrm{H}$, como tipos de contornos de grão, sítios da rede de coincidência especiais (special coincidence site lattice, CSL), entre outros. 


\section{Conclusões}

Com relação à caracterização microestrutural:

- A microestrutura da chapa de aço sour apresentou microestrutura composta por matriz de ferrita refinada, com pequenas colônias de perlita espalhadas de maneira aleatória e homogênea pela matriz, fração volumétrica de perlita em torno de $5 \%$, sem bandeamento, com pequenas inclusões arredondadas de $\mathrm{Al}-\mathrm{O}-\mathrm{Ca}$, distribuídas homogeneamente pela microestrutura e com dispersão aleatória. Ainda, verificou-se que a microestrutura como um todo é homogênea ao longo da espessura da chapa.

- A microestrutura da chapa de aço alto Mn, por sua vez, é altamente bandeada, formada por bandas de ferrita e de perlita. As colônias de perlita neste aço possuem dimensões maiores do que as do aço sour e aparecem em fração volumétrica maior, em torno de $13 \%$. O tamanho de grão ferrítico é menos refinado e varia ao longo da espessura da chapa; o material apresenta alto grau de segregação de Mn na linha central, que reflete na formação de uma banda composta por agregados eutetóides diferentes dos observados nas outras regiões da chapa (regiões das bordas e 1/4 de bordas). As suas inclusões têm formatos e distribuição pelo material heterogêneos, com composição química também heterogênea, porém com elementos como $\mathrm{Ca}, \mathrm{Al}$ e $\mathrm{O}$ sempre presentes.

Com relação aos ensaios de permeabilidade de hidrogênio:

- Os ensaios de permeabilidade mostraram valores de $D_{\text {eff }} t_{\text {lag }}$ do aço alto $\mathrm{Mn}$ ligeiramente inferiores aos do aço baixo $\mathrm{Mn}$. Os valores mais baixos de $\mathrm{D}_{\text {eff }} \mathrm{t}_{\mathrm{lag}}$ do aço alto Mn foram atribuídos à maior quantidade de interface ferrita/cementita, provenientes das bandas de perlita fina presentes em sua microestrutura, junto da contribuição de interfaces de microconstituintes de alta dureza encontrados na banda central da chapa.

- Os valores de $\mathrm{C}_{0}$ e de $\mathrm{N}_{\mathrm{t}}$ também foram calculados para os dois aços e, curiosamente, o aço baixo $\mathrm{Mn}$, que têm os valores de $\mathrm{D}_{\text {eff }} \mathrm{t}_{\mathrm{lag}}$ mais elevados e supostamente menos traps de $\mathrm{H}$, apresentou maiores valores de $\mathrm{C}_{0}$ e de $\mathrm{N}_{\mathrm{t}}$ do que o aço alto Mn. Este resultado levantou hipótese de haver nanocarbonetos de $\mathrm{Nb}$ distribuídos homogeneamente pelo volume do material. Medidas de espectroscopia de dessorção térmica foram realizadas, em caráter preliminar, em todos os tipos de amostras dos dois aços e seus resultados confirmaram que o aço baixo Mn aprisiona mais $\mathrm{H}$ do que o aço alto $\mathrm{Mn}$ e reforçaram a hipótese da presença de $\mathrm{NbC}$.

Com relação à anisotropia da difusividade do hidrogênio: 
- Nos dois aços observou-se que o $D_{\text {eff }} t_{\text {lag }}$ variou em função da direção da seção analisada. A anisotropia observada foi a mesma para os dois aços: $D_{\text {eff }} t_{\text {lag }}$ das amostras longitudinais e transversais foram maiores do que os $D_{\text {eff }} t_{\text {lag }}$ das amostras topo, e $D_{\text {eff }} t_{\text {lag }}$ das amostras topo apresentaram grande dispersão dos resultados.

- A anisotropia do $D_{\text {eff }} t_{\text {lag }}$ no aço alto Mn foi associada ao bandeamento. Nas seções longitudinal e transversal, a difusão se dá preferencialmente pelas bandas de ferrita; na seção topo, como o H entra na direção normal a este plano, não vê mais a microestrutura bandeada e sim formada por ferrita e placas de perlita; estas últimas dificultam a sua movimentação pela estrutura. Por meio do cálculo do coeficiente de difusão do $\mathrm{H}$ no estado estacionário, $\mathrm{D}_{\mathrm{ss}}$, que considera que todos os traps de $\mathrm{H}$ estão saturados, foi possível validar a hipótese de que as placas de perlita atuam como obstáculos físicos à movimentação dos átomos de $\mathrm{H}$ : o $\mathrm{D}_{\mathrm{ss}}$ variou em função da seção ensaiada do mesmo modo que o $D_{\text {eff }} t_{\text {lag }}$.

- Para o aço baixo Mn, a anisotropia do $D_{\text {eff }} t_{\text {lag }}$ foi relacionada ao comprimento de contornos de grão (alto, médio e baixo ângulo) na superfície de entrada de H no material. Quanto maior o comprimento dos contornos de grão, maior o $D_{\text {eff }} t_{\text {lag. }}$. A variação do $D_{s s}$ em função da seção ensaiada não coincidiu com a observada para o $D_{\text {eff }} t_{\text {lag }}$, indicando que outra característica do material influência a difusão do H quando o estado estacionário é atingido. Essa característica é a textura, pouco pronunciada em aços laminados a quente e, por isso, mascarada pela influencia de contornos de grão e saturação dos traps antes do estado estacionário ser atingido. A relação de $\mathrm{D}_{\mathrm{ss}}$ com textura indica a possibilidade de que planos $\{111\}$ e a ausência de textura retardam a difusão do H na estrutura $\mathrm{CCC}$, enquanto que planos $\{001\}$ e $\{101\}$ favorecem a sua difusão. 


\section{Sugestões para trabalhos futuros}

$\left.1^{a}\right)$ Análises microestruturais dos dois aços por microscopia eletrônica de transmissão, para caracterizar os nanocarbonetos presentes neles, em especial no aço baixo Mn, e medir a sua fração volumétrica;

$2^{a}$ ) Identificar corretamente os tipos de textura, medidas por EBSD, no aço baixo Mn e fazer a sua quantificação;

$3^{a}$ ) Fazer novas análises de textura por meio de Difração de Raios X, para que maiores áreas do material sejam analisadas;

$4^{\mathrm{a}}$ ) Medir a textura do aço alto Mn. Mesmo com o bandeamento se mostrando bastante influente na difusão do $\mathrm{H}$, por causa das variações iguais dos $\mathrm{D}_{\text {eff }}$ e D' em função das seções ensaiadas, é importante caracterizar a textura deste aço, para correlação com resultados de HIC feitos por membros do grupo em período anterior ao do presente mestrado. 


\section{Referências Bibliográficas}

[1] Superintendência de Pesquisa e Desenvolvimento Tecnológico da ANP. Tendências de longo prazo no cenário energético mundial: Agência Nacional de Energia - WEO 2013. Julho de 2014. Disponível em: www.anp.gov.br/?dw=71559.

[2] International Energy Agency. World Energy Outlook 2012. Disponível em: http://www.worldenergyoutlook.org/weo2012/\#d.en.26099.

[3] Fragiel A, Schouwenaarf R, Guardián R, Pérez R. Microstructural characteristics of different commercially available API 5L X65 steels. Journal of New Materials for Electrochemical Systems. 2005;8:115-119.

[4] Chiaverini V. Aços e ferros fundidos: características gerais, tratamentos térmicos, principais tipos. $7^{a}$ edição. São Paulo: Associação Brasileira de Metalurgia e Materiais; 2008.

[5] Carneiro RA, Ratnapuli RC, Lins VFC. Influence of chemical composition and microstructure of API linepipe steels on hydrogen induced cracking and sulfide stress corrosion cracking. Materials Science and Engineering A. 2003;357:104-110.

[6] Nayak SS, Misra RDK, Hartmann J, Siciliano F, Gray JM. Microstructure and properties of low manganese and niobium containing HIC pipeline steel. Materials Science and Engineering A. 2008; 494: 456-463.

[7] Nieto J, Elías T, López G, Campos G, López F, De AK. Process and quality controls for production of linepipe slabs for sour service applications at ArcelorMittal Lazaro Cardenas, Mexico.CBMM. Proceedings of the Microalloyed Steels for Sour Service International Seminar; 2012; São Paulo, Brasil. Araxá: CBMM; 2012.

[8] Gray JM. Preface to Microalloying ' $75-40^{\text {th }}$ Anniversary Edition. Microalloying 75 Proceedings... of an International Symposium on High-Strenght, Low Alloy Steels, Edição do 40 Aniversário. 2015: sem numeração das páginas.

[9] Cochrane RC. Phase transformations in microalloyed high strength low alloy (HSLA) steels. Phase transformations in steels - Volume 2: Diffusionless transformations, high strength steels, modeling and advanced analytical techniques. 2a edição. Woodhead Publishing; 2012.

[10] Pickering FB. High Strenght, Low-Alloy steels - A decade of progress. Microalloying 75 - Proceedings... of an International Symposium on High-Strenght, Low Alloy Steels, Edição do $40^{\circ}$ Aniversário. 2015; 9-30.

[11] Sampath K. An understanding of HSLA-65 plate steels. Journal of Materials Engineering and Performance. 2006; 15(1):32-40.

[12] Brandão BP. Influência do tempo de imersão em solução aquosa contendo $\mathrm{H}_{2} \mathrm{~S}$ sobre a tenacidade de tubo API 5L X65 sour avaliada a partir de ensaio Charpy [dissertação de mestrado]. São Paulo: Universidade de São Paulo: 2015. 
[13] Hincapie-Ladino D. Resistência à corrosão e ao trincamento induzido por hidrogênio de aços para tubos API 5L X65 [dissertação de mestrado]. São Paulo: Universidade de São Paulo: 2012.

[14] Ramírez MFG. Estudo da transformação durante o resfriamento contínuo e da microestrutura do aço microligado X80 utilizado na construção de tubos para transporte de gás natural e petróleo [dissertação de mestrado]. São Paulo: Universidade de São Paulo: 2008.

[15] Kliber J, Schindler I. Recrystallization/precipitation behaviour in microalloyed steels. Journal of Materials Processing Technology. 1996; 60: 597-602.

[16] Hincapie-Ladino D, Falleiros NA. Trincamento induzido por hidrogênio em aços microligados. Tecnologia em Metalurgia, Materiais e Mineração. São Paulo. 2015; 12(1): 8293.

[17] Ramírez MFG. Influência da microestrutura nas propriedades mecânicas e na fragilização por hidrogênio em um aço microligado [tese de doutorado]. São Paulo: Universidade de São Paulo; 2012.

[18] Ogata PH. Caracterização microestrutural do aço para tubo API 5L X65 em diferentes regiões da chapa como laminada e após austenitização e resfriamento sob diversas taxas de resfriamento [dissertação de mestrado]. São Paulo: Universidade de São Paulo: 2009.

[19] Stalheim DG, Barnes KR, McCutcheon DB. Alloy designs for high strength oil and gas transmission linepipe steels. In: The Minerals, Metals \& Materials Society. Anais do International Symposium on Microalloyed Steels for the Oil and Gas Industry; 2006; Araxa, Brasil; p. 73-108.

[20] Baker TN. Microalloyed Steels. Ironmaking \& Steelmaking - Processes, Products and Applications. 2016; 43(4): 264-307.

[21] American Petroleum Institute. API 5L: Specification for Line Pipe. Estados Unidos, 2004. 166p.

[22] Bauer J, Flu"ss P, Amoris E, Schwinn V. Microstructure and properties of thermomechanical controlled processing steels for linepipe applications. Ironmaking \& Steelmaking - Processes, Products and Applications. 2005; 32(4): 324-330.

[23] Kozasu I. Processing - Thermomechanical Controlled Processing. Materials Science and Technology. 2006. DOI: 10.1002/9783527603978.mst0065.

[24] Tamura I, Sekine H, Tanaka T, Ouchi C. Thermomechanical Processing of High-strentgh Low-alloy Steels. Londres: Butterwoths, 1988.

[25] Cohen M, Walter SO. An interpretive summary by the Rapporteurs: Thermo-Mechanical Processing of Microalloyed Steels. Microalloying 75 - Proceedings...of an International Symposium on High-Strenght, Low Alloy Steels, Edição do 40 Aniversário. 2015; 2-8. 
[26] Mohtadi-Bonab MA, Karimdadashi R, Eskandari M, Szpunar JA. Hydrogen-induced cracking assessment in pipeline steels through permeation and crystallographic texture measurements. Journal of Materials and Engineering Performance. 2016; 25(5): 1781-1793.

[27] Nieto G, et. al. Effective Process Design for the Production of HIC-Resistant Linepipe Steels. Journal of Materials Engineering and Performance. 2013; 22(9): 2493-2499.

[28] Al-Mansour M, Alfantazi AM, El-boujdaini M. Sulfide stress cracking resistance of APIX100 high strenght low alloy steel. Materials and Design. 2009;30:4088-4094.

[29] Serna S, Martínez H, López SY, González-Rodríguez JG, Albarrán JL. Electrochemical technique applied to evaluate the hydrogen permeability in microalloyed steels. International Journal of Hydrogen Energy. 2005; 30: 1333-1338.

[30] Fallahmohammadi F, Bolzoni F, Lazzari L. Measurement of lattice and apparent diffusion coefficient of hydrogen in X65 and F22 pipeline steels. International Journal of Hydrogen Energy. 2013; 38: 2531-2543.

[31] Fallahmohammadi E, Bolzoni F, Fumagalli G, Re G, Benassi G, Lazzari L. Hydrogen diffusion into three metallurgical microstructures of a C-Mn X65 and low alloy F22 sour service steel pipelines. International Journal of Hydrogen Energy. 2014; 39: 13300-13313.

[32] Haq AJ, Mukaza K, Dunne DP, Calka A, Pereloma EV. Effect of microstructure and composition on hydrogen permeation in X70 pipelines steels. International Journal of Hydrogen Energy. 2013; 38:2544-2556.

[33] Sha Q, Dahang Li. Microstructure, mechanical properties and hydrogen induced cracking susceptibility of X80 pipeline steel with reduced Mn content. Materials Science \& Engineering A. 2013; 585: 214-221.

[34] Eliyan FF, Mahdi ES, Alfantazi Akram. Electrochemical evaluation of the corrosion behavior of API-X100 pipeline steel in aerated bicarbonate solutions. Corrosion Science. 2012; 58: 181-191.

[35] Gray JM, Siciliano F. High strength microalloyed linepipe: half a century of evolution. Microalloyed Steel Institute. 2009; 20-45.

[36] Shi X, Yan W, Wang W, Shan Y, Yang K. Novel Cu-bearing high-strenght pipeline steels with excellent resistance to hydrogen-induced cracking. Materials and Design. 2016; 92: 300-305.

[37] Huang F, Liu J, Deng ZJ, Cheng JH, Lu ZH, Li XG. Effect of microstructure and inclusions on hydrogen induced cracking susceptibility and hydrogen trapping effiency of X120 pipeline steel. Materials Science and Engineering A. 2010; 527: 6997-7001.

[38] Zhou C, Chen X, Wang Z, Zheng S, Li X, Zhang L. Effects of environmental conditions on hydrogen permeation of X52 pipeline steels exposed to high $\mathrm{H}_{2} \mathrm{~S}$-containning solutions. Corrosion Science. 2014; 89: 30-37. 
[39] Zhou C, Zheng S, Chen C, Lu G. The effect of the partial pressure of $\mathrm{H}_{2} \mathrm{~S}$ on the permeation of hydrogen in low carbon pipeline steel. Corrosion Science. 2013; 67: 184-192.

[40] ASTM International. G148-97: Standard practice for evaluation of hydrogen uptake, permeation, and transport in metals by an electrochemical technique. Estados Unidos, 2003. $10 \mathrm{p}$.

[41] Thomas RLS, Li D, Gangloff RP, Scully JR. Trap-governed hydrogen diffusivity and uptake capacity in ultrahigh-strength AERMET 100 steel. Metallurgical and Materials Transactions A. 2002; 33(A): 1991-2004.

[42] Svoboda J, Mori G, Prethaler A, Fischer FD. Determination of trapping parameters and the chemical diffusion coefficient from hydrogen permeation experiments. Corrosion Science. 2014;82: 93-100.

[43]Davis JR. Corrosion: understanding the basics. Estados Unidos: ASM International; 2000.

[44] Lee JY e Lee SM. Hydrogen trapping phenomena in metals with bcc and fcc crystal structures by the desorption thermal analysis technique. Surface and Coatings Technology, 1986; 28: 301-314.

[45] Oriani RA. The diffusion and trapping of hydrogen in steel. Acta Metallurgica. 1970; 18: 147-157.

[46] Yang K, Cao MZ, Wan XJ, Shi CX. Modeling of H diffusion in metals. Scripta Metallurgica, 1989; 23: 203-206.

[47] Hincapie-Ladino DH. Corrosão, absorção e danos provocados por hidrogênio em aços microligados [Tese de Doutorado]. São Paulo: Universidade de São Paulo; 2016.

[48] Li D, Gangloff RP, Scully JR. Hydrogen trap states in ultrahigh-strenght AERMET 100 Steel. Metallurgical and Materials Transactions A, 2004; 35A: 849-864.

[49] Malitckii E, Yagodzinskyy Y, Hänninen H. Hydrogen charging process instrument. Fusion Engineering and Design, 2015; 100: 142-145.

[50] Choo WY, Lee JY. Thermal analysis of trapped hydrogen in pure iron. Metallurgical Transactions A, 1982; 13A: 135-140.

[51] Turnbull A, Hutchings RB. Analysis of hydrogen atom transport in a two-phase alloy. Materials Science and Technology A, 1994; 177: 161-171.

[52]Hong GW, Lee JY. The interaction of hydrogen and the cementite-ferrite interface in carbon steel. Journal of Materials Science, 1983; 18: 271-277.

[53] Findley KO, O’Brien MK, Nako H. Critical Assessment 17: Mechanisms of hydrogen induced cracking in pipeline steels. Materials Science and Technology, 2015; 31(14): 16721680. 
[54] Choo WY, Lee JY. Effect of cold working on the hydrogen trapping phenomena in pure iron. Metallurgical Transactions A, 1983; 14: 1299-1305.

[55] Bhadeshia HKDH. Prevention of hydrogen embrittlement in steels. ISIJ International, 2016; (56): 24-36.

[56] Wei FG, Tsuzaki K. Hydrogen trapping phenomena in martensitic steels. Gaseous hydrogen embrittlement of materials in energy technologies - Volume 1: The problem, its characterization and effects on particular alloy classes. 1a edição. Woodhead Publishing; 2012.

[57] Wallaert E, Devoper T, Arafin M, Verbeken K. Thermal desorption spectroscopy evaluation of the hydrogen-trapping capacity of $\mathrm{NbC}$ and $\mathrm{NbN}$ precipitates. Metallurgical and Materials Transactions A, 2014; 45: 2412-2420.

[58] Pressouyre GM. Communications: A classification of hydrogen traps in steels. Metallurgical Transactions A, 1979; 10: 1571-1573.

[59] Turnbull A. Hydrogen diffusion and trapping in metals. Gaseous hydrogen embrittlement of materials in energy technologies - Volume 2: Mechanisms, modeling and future developments. 1a edição. Woodhead Publishing; 2012.

[60] Krauss G. Solidification, segregation and banding in carbon and alloy steels. Metallurgical and Materials Transactions B, 2003; 34:781-792.

[61] Shirley AI, Hall CK. Trapping of hydrogen by substitutional and interstitial impurities in alpha-iron. Perspectives in Hydrogen in Metals - Collected Papers on the Effect of Hydrogen on the Properties of Metals and Alloys. Pergamon Books Ltd.; 1986.

[62] Yang K, Cao MZ, Wan XJ, Shi CX. Trapping of hydrogen by titanium atoms in alphairon. Scripta Metallurgica, 1988; 22: 1373-1378.

[63] Counts WA, Wolverton C, Gibala R. First-principles energetic of hydrogen traps in alpha-iron: point defects. Acta Materialia, 2010; 58: 4730-4741.

[64] Tau L, Chan SLI. Effects of ferrite/pearlite alignment on the hydrogen permeation in a AISI 4130 steel. Materials Letters. 1996;29: 143-147.

[65] Liu Q, Venezuela J, Zhang M, Zhou Q, Atrens A. Hydrogen trapping in some advanced high strength steels. Corrosion Science, 2016; 111: 770-785.

[66] Depover T, Verbeken K. The effect of TiC on the hydrogen induced ductility loss and trapping behavior of Fe-C-Ti alloys. Corrosion Science, 2016; 112: 308-326.

[67] Turnbull A, Carrol MW. The effect of temperature and $\mathrm{H}_{2} \mathrm{~S}$ concentration on hydrogen diffusion and trapping in a $13 \%$ chromium martensitic stainless steel in acidified $\mathrm{NaCl}$. Corrosion Science. 1990; 30(6/7): 667-679. 
[68] Devanathan MAV, Stachurski Z. The adsorption and diffusion of electrolytic hydrogen in palladium. Proceedings of the Royal Society of London. Series A, Mathematical and Physical Sciences. 1962; 270(1340): p. 90-102.

[69] Bernstein IM. The role of hydrogen in the embrittlement of iron and steel. Materials Science and Engineering, 1970; 6: 1-19.

[70] Manolatos P, Jerome M, Galland J. Necessity of a palladium coating to ensure hydrogen oxidation during electrochemical permeation measurements on iron. Electrochimica Acta. 1995; 40 (7): 867-871.

[71] Yang J, Huang F, Guo Z, Rong Y, Chen N. Effect of retained austenite on the hydrogen embrittlement of a medium carbon quenching and partitioning steel with refined microstructure. Materials Science and Engineering A, 2016; 665: 76-85.

[72] López-Martínez E, Vergara-Hernández HJ, Flores O, Campillo B. Hydrogen diffusivity in the welding zone of two high strength experimental microalloyed steels. ISIJ International, 2015; 55: 2435-2442.

[73] Araújo DF, Vilar EO, Palma Carrasco J. A critical review of mathematical models used to determine the density of hydrogen trapping sites in steels and alloys. International Journal of Hydrogen Energy, 2014; 39: 12194-12200.

[74] Koh SU, Lee JM, Yang BY, Kim KY. Effect of molybdenum and chromium addition on the susceptibility to sulfide stress cracking of High-Strenght, Low-Alloy steels. Corrosion The Journal of Science and Engineering, 2007; 63(3): 220-230.

[75] Jiang DE, Carter EA. Diffusion of interstitial hydrogen into and through bcc Fe from first principles. Physical Review B, 2004; 70: 1-9.

[76] Raabe D. Texture. [mensagem pessoal] Mensagem recebida por: hgoldens@usp.br em 12/10/2016.

[77] Bunge HP. Texture Analysis in Materials Science - Mathematical Methods. Edição Digital, Helga and Hans-Peter Bunge, 2015.

[78] Cao Y, Li HL, Szpunar JA, Shmayda W. Effects of textures on hydrogen diffusion in nickel. Materials Science Forum, 2002; 408-412: 1139-1144.

[79] Hull D, Bacon DJ. Introduction to dislocations. Elsevier, 2011.

[80] Masoumi M, Herculano LFG, Gomes de Abreu HF. Study of texture and microsctructure evaluation of steel API 5L X70 under various thermomechanical cycles. Materials Science and Engineering A, 2015; 639: 550-558.

[81] Masoumi M, Silva CC, Gomes de Abreu HF. Effect of crystallographic orientations on the hydrogen-induced cracking resistance improvement of API 5L X70 pipeline steel under various thermomechanical processing. Corrosion Science, 2016; 111: 121-131. 
[82] Chan SLI. Hydrogen trapping of steels with different microstructures. Journal of the Chinese Institute of Engineers, 1999; 22(1): 43-53.

[83] Chan SLI, Charles JA. Effect of carbon content on hydrogen occlusivity and embrittlement of ferrite-pearlite steels. Materials Science and Technology, 1986; 2(9): 956962.

[84] ASTM International. E45-13: Standard test methods for determining the inclusion content of steel, Estados Unidos, 2013. 19p.

[85] ASTM International. E384-11: Standard test method for Knoop and Vickers hardness of materials. Estados Unidos, 2012. 43p.

[86] ASTM International. E1245-03: Standard Practice for Determining the Inclusion or Second-Phase Constituent Content of Metals by Automatic Image Analysis. Estados Unidos, 2008. 8p.

[87] ASTM International. E112-13: Standard tests methods for determining average grain size. Estados Unidos, 2013. 28p.

[88] Schwartz AJ, Kumar M, Adams BL, Field DP. Electron backscatter diffraction in materials science. 2a edição. Springer; 2009, Nova York, Estados Unidos.

[89] Randle V. Applications of electron backscatter diffraction to materials science: status in 2009. Journal of Materials Science. 2009; 44:4277-4218.

[90] Koll L, Tsipouridis P, Werner EA. Preparation of metallic samples for electron backscatter diffraction and its influence on measured misorientation. Journal of Microscopy. 2011; 243(2): 206-219.

[91] Ariza EA, Nishikawa AS, Goldenstein H, Tschiptschin AP. Characterization and methodology for calculating the mechanical properties of a TRIP-steel submitted to hot stamping and quenching and partitioning. Materials Science and Engineering A, 2016; 671: 54-59.

[92] Doyama LH. Implementação do ensaio de permeabilidade de hidrogênio no LabH2S do PMT/EPUSP [monografia]. São Paulo: Universidade de São Paulo; 2013.

[93] American Welding Society. AWS A4.3-93 Standard methods for determination of the diffusible hydrogen content of martensitic, bainitic and ferritic steel weld metal produced by arc welding. Estados Unidos, 1992. 27p.

[94] European Committee for Standardization. ISO 3690 Welding and allied processes Determination of hydrogen content in arc weld metal. Reino Unido, 2012. 32p.

[95] Hernández JSG. Caracterização metalográfica e resistência à fratura induzida por hidrogênio em um aço microligado X65 baixo $\mathrm{Mn}$ e alto $\mathrm{Nb}$ para serviço SOUR [monografia]. São Paulo: Universidade de São Paulo; 2014. 
[96] Raabe D. Overview on basic types of hot rolling textures of steels. Steel Research, 2003; 74(5): 327-337.

[97] Wei FG, Tsukazi K. Hydrogen absorption of incoherent TiC particles in iron from environment at high temperatures. Metallurgical and Materials Transactions A, 2004; 35: 3155-3163.

[98] Lee HG, Lee JY. Hydrogen trapping by TiC particles in iron. Perspectives in Hydrogen in Metals - Collected Papers on the Effect of Hydrogen on the Properties of Metals and Alloys. Pergamon Books Ltd.; 1986.

[99] Fiori MAP, Pereira VSM, Hincapie-Ladino DH, Falleiros NA, Goldenstein H, de Melo HG. Efeito do teor de nióbio e manganês sobre a permeabilidade de hidrogênio e comportamento eletroquímico de aços para tubos API 5L X65 sour em meio contendo $\mathrm{H}_{2} \mathrm{~S}$.Trabalho publicado nos anais do Congresso Internacional de Corrosão (Intercorr) 2016. Búzios , Rio de Janeiro, 16 a 20 de maio de 2016.

[100] Falleiros NA. Discussão em Banca de Exame de Qualificação. Data: 24/06/2016. 


\section{APÊNDICE A: Método termomecânico de laminação controlada, (TMCR)}

Os elementos de liga, em especial as microadioões, têm importante papel no TMCR dos aços de alta resistência e baixa liga. Para facilitar o entendimento do processo como um todo, primeiro serão explicadas as etapas do TMCR e as alterações microestruturais geradas em cada uma delas; depois, será discutido o efeito dos principais elementos de liga durante o TMCR.

\section{Etapas do TMCR e as microestruturas resultantes}

Para explicar o processo termomecânico de laminação controlada, não serão mencionados os efeitos dos elementos de liga e de possíveis precipitações na recristalização da austenita.

O método pode ser dividido em quatro etapas: (i) reaquecimento da chapa, (ii) desbaste, (iii) acabamento, (iv) resfriamento. A Figura A1 contém uma esquematização do processo, retirada de [1].

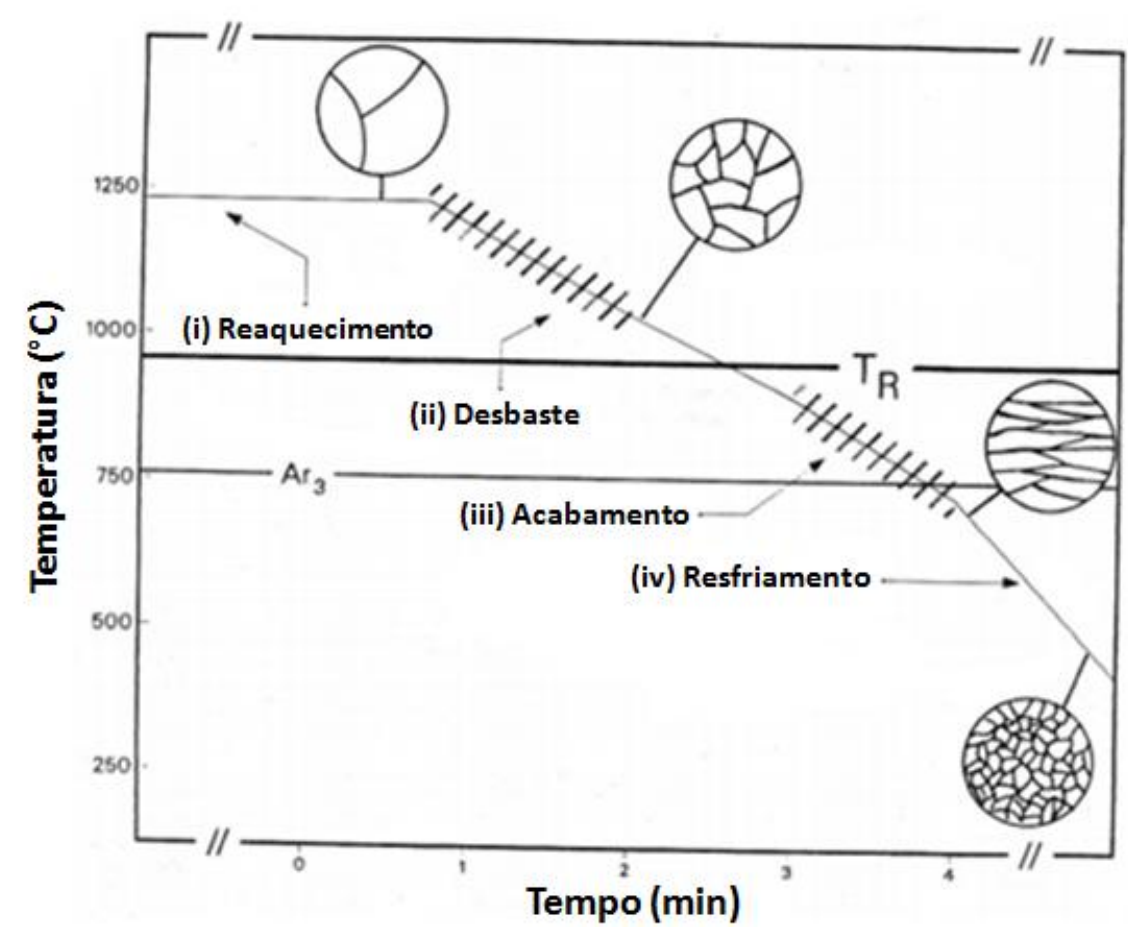

Figura A1. Perfil de temperatura x tempo para laminação controlada de aços. Modificado de [1]. 
$\mathrm{Na}$ etapa (i), antes do inicio da laminação, é feito o encharque do aço a uma determinada temperatura. Com isso, o aço é austenitizado, os microconstituintes, como os carbonetos/carbonitretos/nitretos, são dissolvidos e elementos de liga entram em solução. Temperaturas muito altas de reaquecimento da chapa, de $1250{ }^{\circ} \mathrm{C}$, por exemplo, promovem maior dissolução de microconstituintes, contudo, o tamanho do grão austenítico aumenta. Para a laminação controlada é interessante equilibrar essa questão da dissolução dos microconstituintes com o crescimento do grão austenítico, que deve ser o menor possível [1]. A utilização de microestrutura austenítica refinada e uniforme antes da laminação inibe a formação de microestrutura duplex, após o TMCR, e, assim, leva a um aumento da tenacidade $[1]$.

A etapa (ii), de desbaste, ocorre, normalmente, em temperaturas acima da de recristalização $\left(\mathrm{T}_{\mathrm{R}}\right)$. Seu objetivo é o de refinar os grãos da austenita, por meio de uma série de etapas de laminação/recristalização controladas [1].

No processo de laminação a quente convencional, que não envolve controle algum de suas condições e no qual as etapas de desbaste e acabamento são contínuas, a temperatura do passe de acabamento costuma ser em torno de 1050 a $900{ }^{\circ} \mathrm{C}$, dependendo da espessura da chapa que está sendo trabalhada [2]. Na laminação controlada, no entanto, o acabamento, etapa (iii), pode ser feito de maneiras diferentes, conhecidas na literatura por estágios de laminação. Há divergências entre alguns autores sobre a descrição de cada estágio, apesar das várias similaridades. Em seu livro, Tamura et. al. [2], apresentam três estágios de laminação: um que ocorre na faixa de temperatura de recristalização, outro que acontece abaixo desta faixa e, por último, um estágio que ocorre abaixo da temperatura $\operatorname{Ar}_{3}$, no campo $\gamma+\alpha$. Cohen e Walter, por sua vez, em seu trabalho publicado no Microalloying 75 [3], apresentam quatro estágios, sendo que o "estágio a mais" consiste em operações de laminação em temperaturas no limite de $T_{R}$, podendo haver recristalização completa ou não. Na presente revisão serão apresentados os quatro estágios descritos por Cohen e Walter [3]; todavia, junto das informações pertinentes e complementadoras dadas por Tamura et. al. [2].

A Figura A2, retirada de [3], apresenta as microestruturas austeníticas de três dos quatro estágios descritos por Cohen e Walter [3]. 


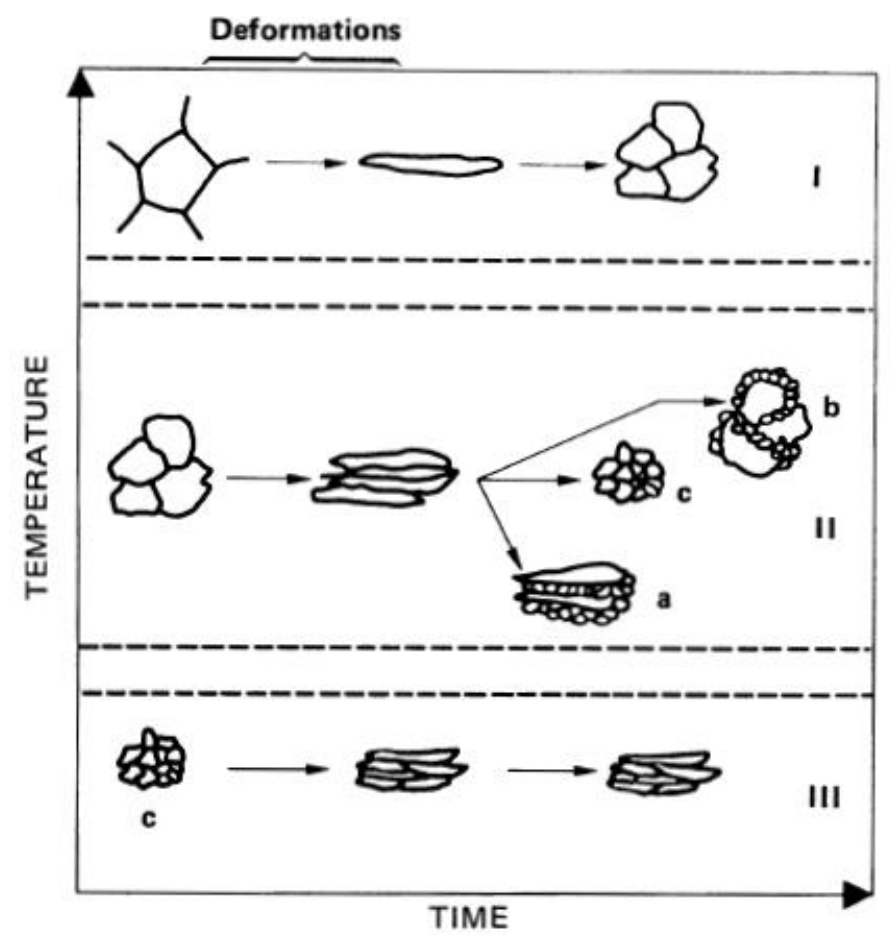

Figura A3. Representação das alterações da austenita no aço, em três estágios de laminação, da etapa de acabamento. Retirado de [3].

No estágio I, a laminação é feita na faixa de recristalização (acima de $1000{ }^{\circ} \mathrm{C}$ ) $[1,2,3]$. Assim como descrito na etapa (ii) de desbaste, o material é submetido a repetidas operações de laminação (representada pelo alongamento do grão na Figura A2) e recristalização, resultando em grãos de austenita refinados [2]. Lembrando que o estágio I é um dos possíveis modos de se fazer a etapa de acabamento - depois disso o material passa pela etapa (iv), de resfriamento, na qual ocorre a transformação de austenita em ferrita. De acordo com [2], geralmente, o tamanho dos grãos recristalizados de austenita diminui rapidamente conforme se aumenta o número de passes de laminação, até atingirem um valor limite, que, por sua vez, restringirá o posterior grau de refinamento da ferrita.

Já no estágio II, a laminação é feita em temperaturas mais baixas, ainda dentro da faixa de recristalização, podendo esta acontecer completamente ou não. Logo, existem outras três possibilidades, neste caso, que Cohen e Walter [3] chamam de "a", "b" e "c" e encontram-se representadas na Figura A2. De acordo com a possibilidade "a", a recristalização é feita de modo incompleto, somente nos contornos de grão austeníticos com formato apanquecado. A possibilidade "b" é a de recristalização completa, porém, junto de crescimento de grão. Por último, a possibilidade "c" é a de que a recristalização completa da austenita gere um bom refinamento de grão [3]. 
No estágio III, correspondente ao estágio II de Tamura et. al. [2], a laminação controlada é feita abaixo da $\mathrm{T}_{R}$, sem possibilidade de haver recristalização. Os grãos de austenita encontram-se no formato de panqueca, ou seja, alongados, e estruturas de deformação são introduzidas em seu interior. Os contornos de grão da austenita e as estruturas de deformação atuam como sítios de nucleação de ferrita e, por isso, a microestrutura ferrítica obtida após este estágio é extremamente fina, mais do que a resultante do estágio IIc $[3,4]$. Segundo Tamura et. al. [2], a capacidade de nucleação intragranular de ferrita nesse estágio é um dos aspectos mais importantes da laminação controlada [2].

O estágio IV, que não é representado na Figura A2, consiste no passe de acabamento da laminação realizado abaixo de $\mathrm{Ar}_{3}$, ou seja, quando a austenita já está se transformando em ferrita. A austenita não transformada é encruada pelo processo de laminação e a ferrita adquire deformações subestruturais (endurecimento por deformação). Podem ser observados no interior dos grãos de ferrita células ou subgrãos de discordâncias [2, 3].

A última etapa do TMCR é o (iv) resfriamento. Nela, dependendo da taxa de resfriamento usada e da composição química da liga, a austenita pode se transformar em ferrita ou em ferrita + outros microconstituintes, citados na Tabela 1 da seção 3.1. da Revisão Bibliográfica.

O modo como foi apresentado o processo de laminação controlada é o reportado por alguns autores clássicos da literatura e, como se pode notar, é explicado com base na temperatura de recristalização, $\mathrm{T}_{\mathrm{R}}$. Este modelo foi escolhido por causa de sua relativa simplicidade para ilustrar o que acontece com a microestrutura do aço durante o TMCR. No entanto, existe outra temperatura muito importante para o processo, vastamente empregada por outros autores, como Gorni [5], Schiavo et. al. [6], Homsher CN [7], e por indústrias, principalmente as brasileiras. Trata-se da temperatura de não-recristalização da austenita, $\mathrm{T}_{\mathrm{NR}}$, considerada como a primeira temperatura crítica para a laminação controlada [7]. A $\mathrm{T}_{\mathrm{NR}}$ é uma temperatura superior à $T_{R}$, na qual a recristalização começa a ocorrer de maneira incompleta $[3,5]$ - também pode ser chamada de $\mathrm{T}_{95 \%}$, indicando que, em seu limite, $95 \%$ da recristalização ocorre [5]. A laminação acima de $\mathbf{T}_{\mathbf{N R}}$ corresponde, então, ao estágio I ilustrado pela Figura A2, no qual a austenita recristaliza por completo.

A segunda temperatura crítica para a laminação controlada é a de recristalização, $T_{R}$, já apresentada, e que foi classificada por Gorni [5] como $\mathrm{T}_{5 \%}$ : abaixo dela não há mais recristalização significativa. A laminação entre $T_{N R}$ e $T_{R}$ pode ser representada pelo estágio II da Figura A2. A terceira temperatura crítica seria a $A_{R 3}$ [7]. De acordo com [5], a prática de 
laminação entre $T_{N R}$ e $T_{R}$ gera microestrutura com tamanho de grão heterogêneo, o que prejudica a tenacidade do aço e, portanto, deve ser evitada.

Para mostrar resultados práticos e microestruturas reais, se tem o trabalho de Kim et. al. [8], de 2014, sobre TMCR em um aço microligado com Ti e Mo. Diferentes amostras do aço passaram por cinco programações de laminação diferentes: (1) com temperatura de início da laminação (Start Rolling Temperature, SRT) e de fim da laminação (Final Rolling Temperature, FRT) na região de recristalização da austenita, (2) SRT na região de recristalização e FRT na de não recristalização da austenita, (3) SRT e FRT na região de não recristalização da austenita, (4) SRT na região de não recristalização da austenita e FRT no campo de $\gamma+\alpha$ e (5) laminação completa na região de $\gamma+\alpha$. A Figura A3, retirada de [8], apresenta graficamente as programações usadas. É importante notar que os autores representam a $\mathrm{T}_{\mathrm{NR}}$ no gráfico (indicada pela seta preta).



Figura A3. Esquematização das programações usadas para o TMCR. Retirado de [8].

A microestrutura resultante de cada processo foi analisada por microscopia óptica, EBSD e microscopia eletrônica de transmissão. Para verificar a influência das diferentes temperaturas de laminação nas propriedades mecânicas do aço, as amostras foram submetidas a ensaios de tração e Charpy.

A Figura A4 contém uma série de mapas obtidos por EBSD em que são apresentadas as microestruturas do aço HSLA após as diferentes programações de TMCR. Nas 
micrografias, as linhas pretas representam os contornos de grão de ferrita, enquanto que as linhas vermelhas mostram os contornos de baixo ângulo, subgrãos, formados por paredes ou subestruturas de discordâncias.
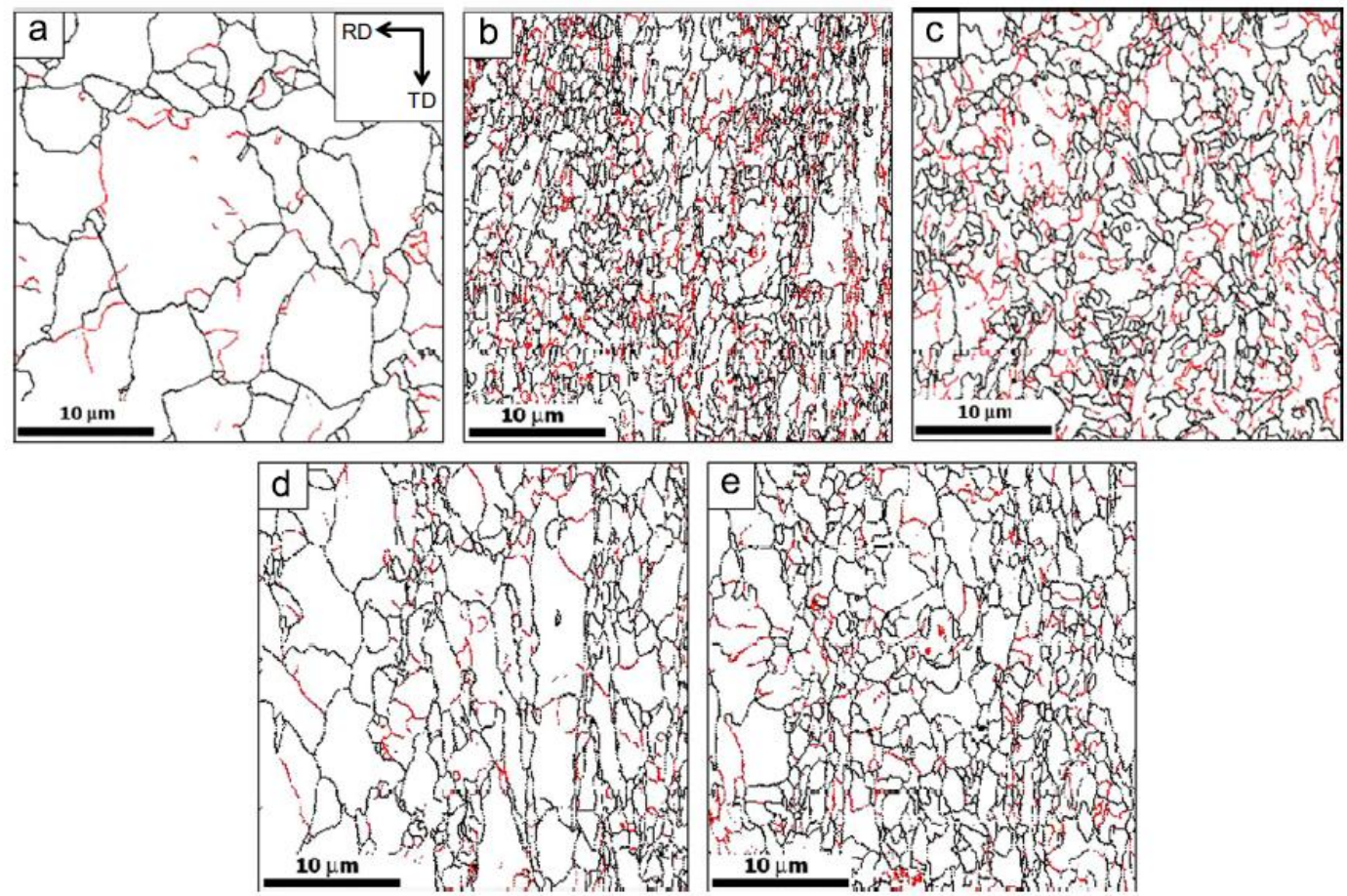

Figura A4. Micrografias de EBSD mostrando as microestruturas de amostras submetidas a diferentes programações de TMCR. (a) Programação 1, (b) 2, (c) 3, (d) 4 e (e) 5. Retirado de [8].

De acordo com os autores, e também pelo que se pode ver na Figura A4, a condição que promoveu o maior grau de refinamento de grãos ferríticos foi a 2 (Figura A4b), em que a temperatura de início da laminação se deu na região de recristalização e a de fim, na região de não recristalização da austenita [8]. Como era esperado, junto do maior grau de refinamento da ferrita veio a maior resistência à tração da condição de laminação 2 , contudo, seus resultados de resistência ao impacto foram ruins. A condição que proporcionou a melhor combinação de resistência e de impacto foi a 3 (todo o processo de laminação realizado na região de não recristalização da austenita). 


\section{Influencia dos elementos de liga no TMCR}

Tanto as adições de elementos de liga (majoritárias, ou macroadições, de $\mathrm{C}, \mathrm{Mn}, \mathrm{Cu}$, $\mathrm{Ni}, \mathrm{Cr}, \mathrm{Mo}$ ) como as microadições ( $\mathrm{Nb}, \mathrm{Ti}, \mathrm{V}, \mathrm{Al}$ ), têm papéis muito importantes para o processamento termomecânico controlado dos aços HSLA. As primeiras determinam o valor da temperatura de transformação $\gamma \rightarrow \alpha, \mathrm{Ar}_{3}$ : quanto mais baixa for essa temperatura, maior será a região de não recristalização da austenita disponível para laminação - e, como se viu na seção anterior, trata-se de uma faixa importante de temperatura para o TMCR, na qual os grãos de austenita adquirem alta densidade de sítios de nucleação de ferrita, por conta do formato achatado e das subestruturas de deformação adquiridas. Ainda, as baixas temperaturas $\mathrm{Ar}_{3}$ levam à supressão do crescimento dos grãos ferríticos, auxiliando na obtenção de ferrita fina. Como o C prejudica a soldabilidade, a ductilidade e a tenacidade, a diminuição da temperatura $\mathrm{Ar}_{3}$ é conseguida através da adição de elementos como o Mn, Ni e o $\mathrm{Cu}$. [9]

As microadições de elementos de liga atuam de três maneiras principais: controlam o tamanho dos grãos de austenita reaquecida (etapa (i) do TMCR), retardam a recristalização da austenita e modificam o comportamento da transformação austenita-ferrita.

O refino dos grãos de austenita reaquecida se dá, principalmente, por causa do efeito de ancoramento (pinning effect) proporcionado por precipitados finos das microadições, como $\mathrm{Nb}(\mathrm{CN}), \mathrm{TiN}, \mathrm{VN}$ e $\mathrm{AlN}$, que não foram dissolvidos durante o reaquecimento $[1,9]$. O Al, que forma o AlN, tecnicamente não é considerado uma microadição, uma vez que é adicionado nos aços mais por conta de sua capacidade de desoxidação, para limpeza do material, e seu excesso é que reage com $\mathrm{N}$ formando os nitretos [10]. Os carbonitretos e nitretos finos precipitam preferencialmente nos contornos de grão da austenita e, dessa forma, os fixam, atuando como alfinetes, e impedem que os grãos austeníticos cresçam. Os TiN são bons contribuintes para a limitação do crescimento do grão austenítico durante o reaquecimento, já que normalmente não se dissolvem nessa etapa - as temperaturas de aquecimento não são altas o suficiente para provocar a sua dissolução [7].

As microadições de elementos de liga são muito conhecidas por seu efeito de atrasar a recristalização da austenita durante ou após a deformação a quente. Os mecanismos responsáveis por este efeito são: (1) o ancoramento dos contornos de grão através da precipitação de nitretos, carbonetos e carbonitretos finos de $\mathrm{Nb}, \mathrm{Ti}, \mathrm{V}$, já explicado no parágrafo anterior, e (2) mecanismo de arraste de soluto (solute drag) [2, 9]. Neste último 
ocorre a segregação dos elementos de liga preferencialmente nos contornos de grão austeníticos, o que reduz a energia interfacial e a mobilidade dos mesmos e, assim, promove a supressão da recristalização. Quanto maior a diferença entre o raio atômico do elemento de liga e do ferro, maior será o efeito de arrasto do soluto e, consequentemente, mais eficiente será a inibição da recristalização [7]. Por causa disso, as temperaturas $T_{N R}$ e $T_{R}$ são aumentadas e a faixa de não recristalização para laminação controlada do material se torna mais ampla.

$\mathrm{O} \mathrm{Nb}$ é uma das microadições mais importantes para os aços HSLA justamente por causa dos dois mecanismos explicados. Devido à grande diferença entre seu raio atômico e o do ferro, a sua solubilidade na austenita é baixa e, portanto, sua tendência para segregar, na forma de soluto, nos contornos de grão é alta [7, 11]. O Nb é um grande formador de carbonetos/carbonitretos; esta característica, aliada a sua baixa solubilidade na austenita, fazem com que o $\mathrm{Nb}$ seja forte elemento contribuinte para o ancoramento dos contornos de grão austeníticos (pinning effect) nas temperaturas de laminação [11]. Depois do $\mathrm{Nb}$, os elementos que aumentam a $\mathrm{T}_{\mathrm{NR}}$ da austenita com maior eficiência são o Ti e o V [6].

Para que as chapas de aços HSLA, resultantes do TMCR, apresentem excelentes propriedades mecânicas, é essencial que se conheça, com exatidão, os valores de $T_{N R}$ e de $T_{R}$, pois, assim, se tem maior controle das condições de laminação e, consequentemente, é obtida uma microestrutura refinada e com tamanho de grão homogêneo [5]. Com base nessa necessidade, alguns modelos matemáticos foram desenvolvidos, ao longo dos anos, para determinar as temperaturas $\mathrm{T}_{\mathrm{NR}}$ e $\mathrm{T}_{\mathrm{R}}$. Uma equação empírica clássica, muito conhecida e usada para estimar o valor $\mathrm{T}_{\mathrm{NR}}$ é a de Boratto (Equação A1), que considera apenas a composição química da liga, apresentada a seguir [5, 7]:

$$
T_{N R}=887+464 C+(6445 N b-644 \sqrt{N b})+(732 V-230 \sqrt{V})+890 T i+363 A l-357 S i
$$

A equação de Boratto (Equação A1) não leva em conta o teor de N, elemento sempre presente nos aços e que forma nitretos com o Ti e o $\mathrm{Al}$ e carbonitretos com o $\mathrm{Nb}$, responsáveis por aumentar o valor de $\mathrm{T}_{\mathrm{NR}}$. Apresenta limitações, uma vez que não considera nenhum parâmetro de deformação [5], além de ser inconsistente com resultados experimentais de ligas que possuam baixos teores de $\mathrm{Nb}$ e de $\mathrm{V}$ e altos teores de $\mathrm{C}$ (acima de 0,17\% em massa) [7]. 
Bai et. al. [12], em seu trabalho, encontraram que a $\mathrm{T}_{\mathrm{NR}}$ decresce com o aumento dos passes de deformação e escreveram uma relação que demonstra essa dependência (Equação A2):

$$
T_{N R}=\beta \exp (-0,36 \varepsilon)
$$

Onde: $\beta=$ coeficiente empírico, cujo valor depende da liga que está sendo estudada e $\varepsilon$ é a deformação.

Existem várias outras equações e metodologias desenvolvidas para calcular os valores de $\mathrm{T}_{\mathrm{NR}}$, porém, como não faz parte do escopo do presente trabalho, não serão apresentadas. $\mathrm{O}$ trabalho de Homsher [7] contém uma revisão detalhada sobre isso e pode ser consultado para maiores informações.

As microadições de elementos de liga também influenciam a transformação $\gamma \rightarrow \alpha$. De acordo com [10], o $\mathrm{Nb}$ e o V retardam a transformação ferrítica; o $\mathrm{Nb}$ pode diminuir a temperatura $\mathrm{Ar}_{3}$ em uma média de, aproximadamente, $8^{\circ} \mathrm{C}$ para cada $0,01 \%$ em massa de $\mathrm{Nb}$ [10]. No entanto, os mecanismos envolvidos ainda não foram completamente desvendados e caracterizados [11].

Em recente trabalho Wang et.al. [11] estudam o efeito do $\mathrm{Nb}$, na forma de átomos de soluto e de precipitados, na transformação isotérmica da austenita em ferrita. Os autores trabalharam com cinco aços HSLA com composição química básica igual, variando apenas o teor de $\mathrm{Nb}$ em cada aço. Todos os aços foram, inicialmente, austenitizados a $1250{ }^{\circ} \mathrm{C}$, acima da temperatura de dissolução dos carbonitretos de Nb. Então, os materiais passaram por vários tratamentos térmicos, para estudo da transformação isotérmica da austenita em ferrita e verificação dos possíveis efeitos de precipitação e de arrasto de soluto sobre a sua cinética. As microestruturas resultantes foram observadas por microscopia óptica e eletrônica de transmissão, e os tratamentos térmicos realizados em um dilatômetro. Ao final dos experimentos, os autores mostraram que o $\mathrm{Nb}$ realmente retarda a transformação de austenita em ferrita e o principal mecanismo envolvido é o de arrasto de soluto - a precipitação tem efeito muito inferior nesse tipo de transformação [11]. 


\section{Referências Bibliográficas do APÊNDICE A}

[1] Cohen M, Hansen SS. On the Fundamentals of HSLA steels. HSLA Steels, Metallurgy and Applications - Proceedings of an International Conference on HSLA Steels '85; 1985; China: 61-71.

[2] Tamura I, Sekine H, Tanaka T, Ouchi C. Thermomechanical Processing of High-strentgh Low-alloy Steels. Londres: Butterwoths, 1988.

[3] Cohen M, Walter SO. An interpretive summary by the Rapporteurs: Thermo-Mechanical Processing of Microalloyed Steels. Microalloying 75 - Proceedings...of an International Symposium on High-Strenght, Low Alloy Steels, Edição do 40 Aniversário. 2015; 2-8.

[4] Kozasu I. Processing - Thermomechanical Controlled Processing. Materials Science and Technology. 2006. DOI: 10.1002/9783527603978.mst0065.

[5] Gorni AA. Cálculo da temperature de não-recristalização para aços microligados, em função da interação entre a precipitação e recristalização da austenita. Revista Escola de Minas. 1999; 52(1): 21-25.

[6] Schiavo CP, Gonzalez BM, Dos Santos AA, Marra KM. Influência dos parâmetros de solubilização, temperatura e tempo de encharque na $\mathrm{T}_{\mathrm{NR}}$ de um aço microligado ao $\mathrm{Nb}, \mathrm{V}$ e Ti. Tecnologia em Metalurgia, Materiais e Mineração. 2011; 8(1): 14-18.

[7] Homsher CN. Determination of the non-recrystallization temperature $\left(\mathrm{T}_{\mathrm{NR}}\right)$ in multiple microalloyed steels [dissertação de mestrado]. Golden, Colorado: Colorado School of Mines; 2013.

[8] Kim YW, Kim JH, Hong SG, Lee CS. Effects of rolling temperature on the microstructure and mechanical properties of Ti-Mo microalloyed hot-rolled high strength steel. Materials Science \& Engineering A. 2014; 605: 244-252.

[9] Kozasu I. Processing - Thermomechanical Controlled Processing. Materials Science and Technology. 2006. DOI: 10.1002/9783527603978.mst0065.

[10] Cochrane RC. Phase transformations in microalloyed high strength low alloy (HSLA) steels. Phase transformations in steels - Volume 2: Diffusionless transformations, high strength steels, modeling and advanced analytical techniques. 2a edição. Woodhead Publishing; 2012.

[11] Wang L, Parker S, Rose A, West G, Thomson R. Effects of solute Nb atoms and Nb precipitates on isothermal transformation kinetics from austenite to ferrite. Metallurgical and Materials Transactions A. 2016; 47(A): 3387-3396.

[12] Bai DQ, Yue S, Sun WP, Jonas JJ. Effect of deformation parameters on the nonrecrystallization temperature in Nb-bearing steels. Metallurgical Transactions A. 1993; 24(A): 2151-2159. 